UNIVERSIDADE DE SÃO PAULO

FACULDADE DE ODONTOLOGIA DE BAURU

CAMILA LOPES CARDOSO

ANÁLISE DA UTILIZAÇÃO DO OSTEOSCAFTM COMO SUBSTITUTO ÓSSEO EM CIRURGIA DE LEVANTAMENTO DE SEIO MAXILAR 

CAMILA LOPES CARDOSO

\section{ANÁLISE DA UTILIZAÇÃO DO OSTEOSCAFTM COMO SUBSTITUTO ÓSSEO EM CIRURGIA DE LEVANTAMENTO DE SEIO MAXILAR}

Tese apresentada à Faculdade de Odontologia de Bauru da Universidade de São Paulo, para obtenção do título de Doutor em Ciências Odontológicas Aplicadas.

Área de concentração Estomatologia.

Orientador: Prof. Dr. Osny Ferreira Júnior

\section{Versão Corrigida}


Camila Lopes Cardoso: Concepção, execução, análises e dissertação do texto.

Bruno Cavenago: Auxílio na fase experimental.

Prof. Dr. Osny Ferreira Júnior: Concepção e orientação.

Prof. Dr. Paulo S. Perri de Carvalho: Concepção e orientação.

Prof. Dr. John Edward Davies: Concepção e orientação laboratorial.

Prof. Dr. Gustavo P. Garlet: Consultoria e biologia molecular.

Prof. Dr. José Roberto Lauris Pereira: Orientação e análise estatística

Márcia Sirlene Zardin Graeff e Tânia Cestari: Orientação na análise microscópica confocal.

Daniel Selmo: Formatação, impressão e encadernação.

Cardoso, Camila Lopes

C179a ANÁLISE DA UTILIZAÇÃO DO OSTEOSCAFTM COMO SUBSTITUTO ÓSSEO EM CIRURGIA DE LEVANTAMENTO DE SEIO MAXILAR /Camila Lopes Cardoso. - Bauru, 2013 $227 \mathrm{p}$; il. ; 30cm.

Tese de Doutorado - Faculdade de Odontologia de Bauru-USP

Orientador: Prof. Dr. Osny Ferreira Júnior

Nota: a versão original desta tese encontra-se disponível no Serviço de Biblioteca da Faculdade de Odontologia de Bauru - FOB/USP

Autorizo, exclusivamente, para fins acadêmicos e científicos, a reprodução total ou parcial desta tese de doutorado, por processos fotocopiadores e outros meios eletrônicos.

Assinatura:

Bauru, 30 de Janeiro de 2013.

Projeto de Pesquisa aprovado pelo Comitê de Ética em pesquisa em animais da FOB-USP em 22 de junho de 2010, processo número 015/2010 
FOLHA DE APROVAÇÃO 



\section{DADOS CURRICULARES}

\section{Camila lopes Cardoso}

Nascimento

Filiação

2001-2004

2003-2004

2005-2007

2006

2007-2009

2009-2013
02/09/1981

Bauru-SP.

Luiz Augusto Andrade Cardoso.

Carmen Regina Lopes Cardoso.

Graduação em Odontologia pela Faculdade de Odontologia de Bauru, Universidade de São Paulo.

Bolsista de Iniciação Científica (CNPQ), sob orientação do Prof. Dr. Luís Antônio de Assis Taveira (Patologia), Faculdade de Odontologia de Bauru, Universidade de São Paulo.

Prática Profissionalizante em Cirurgia junto à Disciplina de Cirurgia da Faculdade de Odontologia de Bauru, Universidade de São Paulo.

Curso de Aperfeiçoamento em Implantodontia IEO (Instituto de Ensino Odontológico, Bauru-SP).

Mestrado em Odontologia, área de concentração em Estomatologia, Faculdade de Odontologia de Bauru, Universidade de São Paulo.

Doutorado em Odontologia, área de concentração em Estomatologia, Faculdade de Odontologia de Bauru, Universidade de São Paulo.

No período de 06/2011 a 03/2012 foi contemplada com bolsa de estudos sanduíche CAPES (Processo: BEX 0328/11-1) para a realização de parte da tese no Institute od Biomaterials and Biomedical Engineering, Toronto, Canadá. 



\section{DEDICATÓRIA}

É com muito amor e agradecimento que dedico este trabalho...

À minha querida filha, Sophia Cardoso Curi, que eu amo tanto e que me deu o privilégio de ser mãe. Mesmo antes de nascer, ela foi cúmplice das minhas análises laboratoriais e companheiríssima durante meu estágio no exterior.

Ao meu marido Marcos Martins Curi, sempre presente, me apoiando profissionalmente e pessoalmente. Sem sua compreensão, seria muito difícil finalizar este trabalho.

Aos meus pais Carmen Regina e Lú, irmãos: Carolina, Bruna, João Luiz e vó Suzana, os quais sempre me apoiaram e permitiram que eu realizasse este trabalho. Além disso, agradeço a todos os meus familiares que torceram muito por mim.

Aos meus sogros Flora, Roberto Curi e cunhados Beto, Flávia, Dani, Cláudia e Marco pela preocupação e apoio durante o período deste trabalho. 



\section{AGRADECIMENTOS}

À toda a minha família, a qual eu dediquei este trabalho. Em especial à minha mãe Carmen Regina, mulher guerreira, em quem me inspiro nesta vida para continuar lutando pelos meus sonhos. Obrigada por tudo que sempre fez por mim! Você é o melhor exemplo de mãe, o qual eu tento ser hoje.

Ao meu marido Marcos Martins Curi, o qual tenho profunda admiração. Agradeço por ter me ajudado a conciliar a maternidade com a finalização deste trabalho. Obrigada pela compreensão, paciência e carinho. Sou uma mulher muito feliz ao seu lado e o considero um pai maravilhoso.

Ao meu orientador Prof. Dr. Osny Ferreira Júnior, quem permitiu a realização deste trabalho, sempre disposto aos questionamentos, orientação e compreensão. Aproveito ainda para agradecer pelos 8 anos de convivência, amizade e profissionalismo.

Ao querido “JED”, Prof. Dr. John Edward Davies, o qual aprimorou meu senso crítico como pesquisadora, através das reuniões semanais, durante os nove meses de estágio, em Toronto.

Ao Prof. Dr. Paulo Sérgio Perri de Carvalho, pela orientação e os 8 anos de convivência, amizade e profissionalismo. Foi uma honra ter a oportunidade de pesquisar no seu grupo.

À Vanessa Mendes, pela parceria profissional e acolhimento em Toronto. Obrigada por sua preocupação comigo e com a Sophia.

Ao Prof. Dr. Gustavo Garlet, pela orientação a distância. Foi um prazer novamente trabalharmos em parceria.

Ao Prof. Dr. Eduardo Sant'Ana, pelos ensinamentos em Cirurgia Bucomaxilofacial e pelos 8 anos de convivência, amizade e profissionalismo. 

Ao Prof. Dr. José Humberto Damante, pelos ensinamentos, dia após dia, os quais me despertaram cada vez mais interesse na área de diagnóstico. Além disso, minhas publicações e prêmios não seriam possíveis sem a sua orientação. Considero um exemplo de professor e de dedicação ao trabalho.

À querida Prof. Dra. Ana Lúcia Álvares Capelozza, obrigada pelos ensinamentos de radiologia e o prazer de poder trabalhar com alguém muito justa, acolhedora, animada e criativa.

À querida Prof. Dra. Izabel Regina Fisher Rubira-Bullen, sempre disposta e pronta para ajudar. Obrigada pelo apoio em todos os momentos, durante o período de pós-graduação.

Ao Prof. Dr. Luiz Eduardo Montenegro Chinellato por sua contribuição em minha formação. Além disso, a sua companhia foi muito prazerosa durante a pós-graduação. Obrigada pelos seus ensinamentos e conselhos.

Ao Prof. Dr. Eduardo Sanches Gonçales, pela confiança em emprestar seu triturador de osso para a realização desta pesquisa e pelos ensinamentos de cirurgia.

Ao Prof. Dr. Renato Yassutaka Faria Yaedú, o qual participou da minha formação desde a prática profissionalizante em cirurgia.

Ao Prof. Dr. Paulo Sérgio da Silva Santos, mesmo tendo convivido pouco tempo, obrigada pelos ensinamentos e pela prontidão em ajudar.

Ao Prof. Dr. Luís Antônio de Assis Taveira, com quem tive o prazer de realizar minha primeira pesquisa durante a graduação e por fazer parte da minha formação. Obrigada por me acolher todos esses anos. Foi um imenso prazer trabalharmos juntos.

Ao Prof. Dr. José Roberto Pereira Lauris pela realização das análises estatísticas.

Ao meu colega Bruno Cavenago, pelo auxílio na parte experimental deste trabalho. 

À Ana Cláudia de Araújo que desde o momento piloto deste trabalho sempre se dispôs a ajudar e orientou sobre o doutorado sanduíche, a qual vivenciou previamente a mesma experiência e pode transmitir muita experiência profissional e pessoal, fundamentais para o andamento do meu estágio fora do país.

À querida Etiene de Andrade Munhoz, pelos momentos de amizade e parceria clínica. Além disso, acompanhou minha formação e me deu oportunidade de escrever alguns artigos durante a pós-graduação.

À querida parceira de clínica Luciana Fernandes, pelos momentos de profissionalismo e amizade. Foi muito prazerosa a nossa convivência.

Aos "irmãos" de pós-graduação Elen de Souza Tolentino e Gabriel Bernini, pela amizade e convivência desde o mestrado. Nunca esquecerei os bons momentos compartilhados durante toda nossa fase de PG.

Aos demais colegas que compartilharam a mesma fase de pós-graduação e que de alguma forma ajudaram ou se preocuparam com este trabalho: Leslie, Christiano Oliveira, Manuela

Rodrigues Godoy, Marcelo Poleti, Marcelo Bonifácio, Carla Ikuta, Heliton Lima, Julierme Rocha, Eduardo Ribeiro, Thaís Imada, Kelen Tjioe, Bruna Centurion, Leandro Scomparim, Maria Fernanda Madeira, Carlos Eduardo (Repeke), Otávio Pagin e Edson Zen.

À veterinária Mariana, pela assistência aos coelhos durante a fase experimental.

À querida Patrícia Freitas-Faria, pela amizade sincera e por todo apoio desde a graduação.

Ao amigo Daniel Salvatore de Freitas pela amizade e parceria clínica.

Aos colegas de laboratório em Toronto: Elnaz Ajami, Limin Guan, Xen-Mei, Catalina, Alejandro, Spencer Bell, Andrea e Kerstin pela convivência e por toda preocupação e carinho com a Sophia. 

Aos meus "roomates" Marquinhos e Natália Ribera, verdadeiros irmãos, em Toronto. Obrigada pelo carinho, compreensão, apoio e companhia durante essa fase tão especial da minha vida.

À querida “Martinha” Cunha, pela amizade. O destino nos colocou vizinhas de laboratório. Obrigada por sua companhia e preocupação comigo e com a Sophia. Os nossos encontros na hora do almoço foram muito especiais.

Às demais amizades vividas em Toronto: Maria Fernanda, Thami, Liciane, Ryan, Angélica, Cintia, Rodrigo, Joyce, Cris Gorla, Fabio, Anurada, Flávia, Marília, Rafael, Paul. Cada um de vocês fez parte da minha história em Toronto tornando-a mais especial.

Aos queridos funcionários do Departamento de Estomatologia: Alexandre Garcia, Andréa Cruz, Fernanda Cavalari, Josieli Farinha, Luciana Lozano, Marília Gião e Roberto Salles, pela prontidão em ajudar. Cada um de vocês deixou sua importância em minha vida.

À profissional Márcia Sirlene Zardin Graeff pela orientação e apoio técnico durante a obtenção das imagens no microscópio confocal do Centro Integrado de Pesquisas.

Às técnicas de laboratório Tânia Cestari, Patrícia Germino e Daniela Ceolin pela orientação laboratorial e prontidão em ajudar.

À querida Profa. Elô Pereira, pela revisão gramatical do texto.

Ao Daniel Selmo "Bonné", pela formatação, impressão e encadernação deste trabalho.

À CAPES, FAPESP, TRT e Bone Interface Group pelo auxílio pecuniário fundamental para a realização deste trabalho.

À direção da Faculdade de Odontologia de Bauru, Universidade de São Paulo, na pessoa do Diretor Prof. Dr. José Carlos Pereira. 

À Comissão de Pós-graduação da Faculdade de Odontologia de Bauru, Universidade de São Paulo, na pessoa do presidente Prof. Dr. Paulo César Rodrigues Conti.

À Coordenadora do Curso de Pós-graduação em Estomatologia, da Faculdade de Odontologia de Bauru, Universidade de São Paulo, Prof. Dra. Izabel Regina Fischer Rubira-Bullen.

Ao Biotério Central do Campus de Bauru, da Faculdade de Odontologia de Bauru, Universidade de São Paulo e os funcionários Erasmo, Luis, Elias e Richard. Obrigada pelo zelo com os coelhos. 



\section{PRECIOSO TEMPO}

Nascemos uma única vez! Afortunados somos pela natureza. Uma segunda vez não nos é dada! Apesar disso, adiamos constantemente o instante certo, sendo que nem ao menos somos donos do dia seguinte.

Nessa vacilação, a vida se esvai, escapa-lhe por entre os dedos e muitos morrem sem a menos provar um pouco de conhecimento, de sabedoria, ou o principal, a filosofia!

Digo que ninguém é jovem ou maduro demais para conhecê-la. Arrisco dizer, que por meio dela, o homem adquire a liberdade absoluta! Elimina o supérfluo e não perde o seu tempo adquirindo riquezas para si próprio ou para a posteridade.

Concluo, que o tempo que aproveitamos ou o que há de ser aproveitado não é o passado, que já pertence à morte, nem ao futuro do acaso, mas o aqui e agora: o presente!

Mensagem filosófica inspirada em trechos de Henry David Throreau e Epicuro.

Marcos Martins Curi 



\section{RESUMO}

Procedimentos de levantamento do seio maxilar têm sido realizados para aumentar o volume ósseo e promover a estabilidade do implante, na região posterior de maxilas severamente atrofiadas. Ao longo dos anos, resultados de vários estudos demonstraram que alguns substitutos ósseos podem suportar implantes em função, após o levantamento de seio maxilar, igual ou melhor quando utilizado o osso autógeno. Neste estudo, foi avaliado o comportamento de um substituto ósseo completamente biodegradável (OsteoScaf ${ }^{\mathrm{TM}}$ ) no modelo experimental de levantamento de seio maxilar em coelhos. Além disso, ele foi comparado com o osso autógeno e outros dois substitutos ósseos, não totalmente biodegradáveis, disponíveis comercialmente (Bio-Oss ${ }^{\circledR}$ e BoneCeramic $\left.{ }^{\circledR}\right)$. Avaliação clínica, tomografia computadorizada por feixe cônico, microtomografia computadorizada, análises microscópicas e análise molecular, através da técnica de PCR, foram realizadas após 2, 4 e 8 semanas de cirurgia. O levantamento de seio maxilar utilizando o osso autógeno demonstrou maior reabsorção, ao longo do tempo, comparado aos substitutos ósseos, os quais revelaram maior neoformação óssea após 8, 4 e 2 semanas, respectivamente. O grupo BioOss® apresentou maior neoformação óssea, ao longo do tempo, quando comparado aos grupos Osteoscaf ${ }^{\mathrm{TM}}$ e BoneCeramic ${ }^{\circledR}$, os quais foram qualitativamente semelhantes. $\mathrm{O}$ grupo BoneCeramic $®$ mostrou uma resposta celular de células gigantes até 8 semanas. Concluiu-se que os substitutos ósseos, neste estudo, obtiveram melhor desempenho do que o osso autógeno, e o OsteoScaf ${ }^{\mathrm{TM}}$ demonstrou maior reabsorção do que os outros grupos, em todos períodos.

Palavras-chave: Levantamento de seio maxilar. OsteoScaf ${ }^{\mathrm{TM}}$. Bio-Oss ${ }^{\circledR}$. BoneCeramic ${ }^{\circledR}$. Substitutos ósseos. Biomateriais. Osteocondução. Material biodegradável. 



\section{ABSTRACT \\ Use of OsteoScaf ${ }^{\mathrm{TM}}$ in maxillary sinus augmentation}

Maxillary sinus augmentation procedures have been applied to increase bone volume and to promote stability of implants in the severely atrophied posterior maxilla. Over the years, the outcomes of several studies have demonstrated that some bone substitutes can support implants in function after sinus augmentation as well as, or better than those with autogenous bone. Our experimental model evaluated the behavior of a fully biodegradable bone substitute (OsteoScaf ${ }^{\mathrm{TM}}$ ) in a rabbit sinus lift procedure. We compared this with autogenous bone and other two available non-biodegradable bone substitutes (Bio-Oss ${ }^{\circledR}$ and BoneCeramic $($ ). Clinical evaluation, Cone Beam Computed Tomography, Microcomputed Tomography, microscopic and molecular evaluation were used for data analysis at 2, 4 and 8 weeks after sinus augmentation. Autogenous bone was more resorbed over time than the other materials. All bone substitutes showed more bone formation at 8, 4 and 2 weeks, respectively. Bio-Oss ${ }^{\circledR}$ showed more bone formation/timepoint than Osteoscaf ${ }^{\mathrm{TM}}$ and Boneceramic $\AA$, which were similar. Boneceramic ${ }^{\circledR}$ showed a florid giant cell response up to 8 weeks. We concluded that the bone graft materials all performed better than autogenous bone and OsteoScaf ${ }^{\mathrm{TM}}$ showed comparative bone growth yet greater degradation than the other two materials.

KEYWORDS: Sinus lift procedure. OsteoScaf ${ }^{\mathrm{TM}}$. Bio-Oss ${ }^{\circledR}$. BoneCeramic $®$. Bone substitutes. Biomaterials. Osteoconduction. Biodegradable material. 



\section{LISTA DE ILUSTRAÇÕES}

\section{- FIGURAS}

Figura 1 - A. OsteoScaf ${ }^{\mathrm{TM}}, \mathrm{B}$. Bio-Oss ${ }^{\circledR}$, C. BoneCeramic $®$ 70

Figura 2 - Imagem do animal após tricotomia e antisepsia nas áreas A. doadora e B. receptora.

Figura 3 - Anestesia infiltrativa na região da pele que recobre a crista ilíaca direita.

Figura 4 - A. Incisão por planos e B. descolamento do periósteo para exposição da crista ilíaca

Figura 5 - Remoção do enxerto ósseo com pinça goiva. 73

Figura 6 - A. Sutura do plano muscular com Vicryl 4.0 e B. da pele com seda 4.0

Figura 7 - Anestesia infiltrativa na região facial receptora. 77

Figura 8 - A. Incisão da pele e B. do periósteo 77

Figura 9 - Descolamento mucoperiosteal 77

Figura 10 - Trefina utilizada no acesso ao seio maxilar

Figura 11 - Acesso ao seio maxilar esquerdo, aproximadamente $5 \mathrm{~mm}$ da sutura nasal

Figura 12 - Levantamento da mucosa sinusal.

Figura 13 - Acesso bilateral aos seios maxilares direito e esquerdo.

Figura 14 - Osso autógeno posicionado no triturador de osso..... 81

Figura 15 - Seringa com a quantidade padronizada do substituto ou enxerto ósseo.

Figura 16 - Preenchimento do seio maxilar direito com osso autógeno triturado

Figura 17 - Seio maxilar direito preenchido com OsteoScaf ${ }^{\mathrm{TM}}$ e esquerdo com osso autógeno 85

Figura 18 - Posicionamento da membrana 85 

Figura 19 - A. Sutura do periósteo com Vicryl 4.0 e B.da pele com Seda 4.0.

Figura 20 - Distribuições das amostras em cada análise dos resultados. .89

Figura 21 - A. Imagem da maxila do coelho removida para análise microscópica e $\mathrm{B}$. a peça dissecada.

Figura 22 - A. Imagem da coleta do espécime para análise molecular e B. a amostra no eppendorf

Figura 23 - A. Reconstruções axial, B. coronal e C. sagital de uma maxila

Figura 24 - MicroCT (MicroCT40, Scanco Medical, Basserdorf, Suíça)

Figura 25 - Macroscopia dos espécimes. A. Maxila fixada em formalina 10\%. B,C. Osteotomia com ponta diamantada 4138 para a fragmentação da peça. D. Maxila dividida em 3 segmentos. E. Visão posterior de hemimaxila esquerda e conteúdo no interior do seio maxilar compatível com o enxerto. F. Visão interna dos seios maxilares individualizados

Figura 26 - Reconstrução coronal do seio maxilar

Figura 27 - Seleção de cortes mais representativos de diferentes áreas, da mesma amostra, para análise qualitativa

Figura 28 - Desenho do volume total realizado com a ferramenta do programa

Figura 29 - Faixa de "slices" ou reconstruções coronais selecionadas para serem desenhadas e analisadas.

Figura 30 - Imagem dos resultados impressos após a quantificação histomorfométrica, calculada pelo programa

Figura 31 - Equipamento Exakt 300 utilizado para o corte dos blocos e confecção das lâminas finais.

Figura 32 - Equipamento Exakt 400 CS utilizado para o desgaste e polimento das lâminas finais.

Figura 33 - Microscópio eletrônico de varredura, modelo Hitachi VPSEM 3400N

Figura 34 - Ilustração da captura da imagem no microscópio eletrônico de varredura 

Figura 35 - Imagem ilustrativa da quantificação do marcador ósseo calceína (em verde), em porcentagem, pelo software AxionVision 40V 4.82.0 (Carl Zeiss MicroImaging GmbH).

Figura 36 - Imagens ilustrativas de reconstruções bidimensionais microtomográficas de uma amostra por período, de cada grupo. A. OsteoScaf ${ }^{\mathrm{TM}}$; B. Bio-Oss ${ }^{\circledR} ;$ C. BoneCeramic ${ }^{\circledR}$ e D. Osso autógeno.

Figura 37 -A. Partículas de BoneCeramic $® ;$ B. Bio-Oss ${ }^{\circledR}$ e C. OsteoScaf ${ }^{\mathrm{TM}}$ após 8 semanas de levantamento de seio maxilar

Figura 38 - Osso autógeno, período de 2 semanas. A presença de partículas maiores e mais hiperdensas corresponde ao enxerto, enquanto finas trábeculas ósseas correspondem ao tecido ósseo neoformado

Figura 39 - Osso autógeno, período de 4 semanas. A presença das partículas do enxerto embora remodeladas, ainda permaneceram com novas finas trábeculas ósseas circundando-as. O volume total se apresentou igual ou menor ao período de 2 semanas

Figura 40 - Osso autógeno, período de 8 semanas. Ausência de partículas do enxerto original que foi remodelado e a presença de espaços vazios entre as trabéculas. A reabsorção óssea, com 8 semanas, se apresentou significante comparada aos outros períodos e grupos experimentais

Figura 41 - OsteoScaf ${ }^{\mathrm{TM}}$, período de 8 semanas. Presença de algumas partículas de fosfato de cálcio, em permeio ao novo tecido ósseo, após a degradação do biomaterial. As trabéculas ósseas se apresentaram interconectadas entre si nas áreas periférica e central

Figura 42 - Bio-Oss ${ }^{\circledR}$, período de 8 semanas. As partículas se apresentaram bem definidas, preservando o formato original e demonstrando ausência de degradação. As trabéculas ósseas circundaram o biomaterial e se interconectaram nas áreas periférica e central.

Figura 43 - BoneCeramic ${ }^{\circledR}$, período de 8 semanas. Partículas apresentaram integridade no formato original, demonstrando ausência total de degradação, somente pequenas áreas hipodensas na superfície do biomaterial sugeriram uma leve degradação. As trabéculas ósseas circundaram o biomaterial e se interconectaram nas áreas periférica e central 

Figura 44 - OsteoScaf ${ }^{\mathrm{TM}}$, período de 4 semanas. Partículas do biomaterial demonstrando sua degradação. Menor presença de tecido ósseo neoformado nas áreas periféricas e principalmente, nas áreas centrais, comparada ao período de 8 semanas

Figura 45 - Bio-Oss ${ }^{\circledR}$, período de 4 semanas. Maior neoformação óssea periférica comparada às regiões centrais

Figura 46 - BoneCeramic ${ }^{\circledR}$, período de 4 semanas. Presença de osso circundando as partículas do biomaterial, porém menor presença de trabéculas ósseas, principalmente, nas áreas centrais

Figura 47 - OsteoScaf ${ }^{\mathrm{TM}}$, período de 2 semanas. Partículas do biomaterial parcialmente degradadas. Presença de menor formação óssea quando comparada aos outros períodos e dificuldade em diferenciar tecido ósseo neoformado das partículas do biomaterial

Figura 48 - Bio-Oss ${ }^{\circledR}$, período de 2 semanas. Período de menor neoformação óssea, principalmente, nas áreas centrais. Presença de tecido ósseo circundando as partículas, porém menor presença e conexão entre as trabéculas

Figura 49 - BoneCeramic ${ }^{\circledR}$, período de 2 semanas. Menor neoformação óssea comparada aos outros períodos, principalmente, na área central

Figura 50 - Gráficos ilustrativos dos resultados do VT em $\mathrm{mm}^{3}$. A. Evolução do VT de cada grupo, ao longo do tempo. B. VT de cada grupo no período de 2 semanas. C. VT de cada grupo no período de 4 semanas. D. VT de cada grupo no período de 8 semanas. OS: OsteoScaf ${ }^{\mathrm{TM}}$, BI: Bio-Oss®, BO: BoneCeramic ${ }^{\circledR}$ e AU: osso autógeno

Figura 51 - Gráficos ilustrativos dos resultados do VO em $\mathrm{mm}^{3}$. A. Evolução do VO ao longo do tempo, de cada grupo. B. VO de cada grupo no período de 2 semanas. C. VO de cada grupo no período de 4 semanas. D. VO de cada grupo no período de 8 semanas. OS: OsteoScaf ${ }^{\mathrm{TM}}$, BI: Bio-Oss ${ }^{\circledR}$, BO: BoneCeramic ${ }^{\circledR}$

Figura 52 - Gráficos ilustrativos dos resultados da relação VO/VT. A. Evolução da VO/VT ao longo do tempo, de cada grupo. B. $\mathrm{VO} / \mathrm{VT}$ de cada grupo no período de 2 semanas. C. VO/VT de cada grupo no período de 4 semanas. D. VO/VT de cada grupo no período de 8 semanas. OS: OsteoScaf ${ }^{\mathrm{TM}}$, BI: BioOss ${ }^{\circledR}$, BO: BoneCeramic $®$. 

Figura 53 - Gráficos ilustrativos dos resultados do NT. A. Evolução do NT ao longo do tempo, de cada grupo. B. NT de cada grupo no período de 2 semanas. C. NT de cada grupo no período de 4 semanas. D. NT de cada grupo no período de 8 semanas. OS: OsteoScaf ${ }^{\mathrm{TM}}$, BI: Bio-Oss ${ }^{\circledR}, \mathrm{BO}:$ BoneCeramic ${ }^{\circledR}$

Figura 54 - Gráficos ilustrativos dos resultados da ET em mm. A. Evolução da ET ao longo do tempo, de cada grupo. B. ET de cada grupo no período de 2 semanas. C. ET de cada grupo no período de 4 semanas. D. ET de cada grupo no período de 8 semanas. OS: OsteoScaf ${ }^{\mathrm{TM}}$, BI: Bio-Oss®, BO: BoneCeramic ${ }^{\circledR}$

Figura 55 - Gráficos ilustrativos dos resultados da ST em mm. A. Evolução da ST ao longo do tempo, de cada grupo. B. ST de cada grupo no período de 2 semanas. C. ST de cada grupo no período de 4 semanas. D. ST de cada grupo no período de 8 semanas. OS: OsteoScaf ${ }^{\mathrm{TM}}$, BI: Bio-Oss ${ }^{\circledR}, \quad$ BO: BoneCeramic $\AA$

Figura 56 - OsteoScaf ${ }^{\mathrm{TM}}$, período de 8 semanas. Osso neoformado (ON) circundando as áreas do biomaterial em degradação (OS). As partículas constituídas por OsteoScaf ${ }^{\mathrm{TM}}$ foram reabsorvidas e perderam seu formato original, restando algumas partículas hiperdensas de fosfato de cálcio em menor quantidade comparada aos períodos anteriores. Todo o biomaterial foi circundado por tecido ósseo e houve conexão entre as trabéculas neoformadas

Figura 57 - OsteoScaf ${ }^{\mathrm{TM}}$, período de 4 semanas. Menor quantidade de neoformação óssea $(\mathrm{ON})$ e biodegradação do material (OS) quando comparada ao período de 8 semanas.

Figura 58 - OsteoScaf ${ }^{\mathrm{TM}}$, período de 2 semanas. Menor quantidade de neoformação óssea (ON) e biodegradação do material (OS) comparada aos outros períodos

Figura 59 - Osso autógeno, período de 8 semanas. Trabéculas ósseas apresentaram aspecto de remodelação e os espaços entre as mesmas foram maiores, indicando reabsorção

Figura 60 - Osso autógeno, período de 4 semanas. Setas indicam áreas levemente mais hiperdensas correspondentes às partículas enxertadas

Figura 61 - Osso autógeno, período de 2 semanas. Várias trabéculas ósseas interconectadas e maior proximidade entre as mesmas, demonstrando período de maior volume ósseo. 

Figura 62 - Bio-Oss ${ }^{\circledR}$, período de 8 semanas. Partículas do biomaterial (BI) circundadas por maior volume ósseo (ON) comparado aos outros grupos

Figura 63 - Bio-Oss ${ }^{\circledR}$, período de 4 semanas. Osso neoformado (ON) circundando as partículas do biomaterial (BI).

Figura 64 - Bio-Oss®, período de 2 semanas. Osso neoformado (ON) circundando as partículas do biomaterial (BI). Período de menor volume ósseo neoformado

Figura 65 - BoneCeramic ${ }^{\circledR}$, período de 8 semanas. Osso neoformado (ON) circundando as partículas do biomaterial (BO). Período de maior volume ósseo neoformado.

Figura 66 - BoneCeramic $\AA$, período de 4 semanas. Osso neoformado (ON) circundando as partículas do biomaterial (BO)

Figura 67 - BoneCeramic ${ }^{\circledR}$, período de 2 semanas. Osso neoformado $(\mathrm{ON})$ circundando as partículas do biomaterial (BO). Período de menor volume ósseo neoformado

Figura 68 - Aspecto de normalidade da membrana sinusal (MS) num espécime correspondente ao grupo osso autógeno (OA), período de 8 semanas. Presença de glândulas serosas (GL) abaixo da região da MS e vasos sanguíneos (VS) em permeio ao enxerto. 10X (HE)

Figura 69 - Outras imagens da MS demonstrando sua integridade após o enxerto com osso autógeno (A) $10 \mathrm{X}$ e OsteoScaf ${ }^{\mathrm{TM}}$ no período de 2 semanas (OS) (B) 4X (HE)......

Figura 70 - Imagem ilustrativa da área de um seio maxilar após enxerto com osso autógeno, no período de 8 semanas. A neoformação óssea se deu da periferia para o centro. 1,6X (HE).....

Figura 71 - Bio-Oss ${ }^{\circledR}$, período de 2 semanas. Presença de osso neoformado $(\mathrm{ON})$ circundando as partículas $(\mathrm{BI})$ na região central. Coloração: Azul de Toluidina (AT) 10X

Figura 72 - Bio-Oss $®$, período de 4 semanas. (A) Presença de osso neoformado (ON) circundando as partículas (BI) 4X (HE). As áreas centrais (B) demonstraram menor quantidade de ON comparado ao período de 8 semanas. 10X (AT). 

Figura 73 - Bio-Oss ${ }^{\circledR}$, período de 8 semanas. Maior presença de osso neoformado $(\mathrm{ON})$ circundando as partículas (BI) comparado aos outros períodos e grupos. A. 4X (HE); B. 10X (AT)

Figura 74 - OsteoScaf ${ }^{\mathrm{TM}}$, período de 8 semanas. Menor quantidade de partículas (OS), as quais se apresentaram em processo de degradação e com (ON) circundando-as. O formato das trabéculas se assemelha ao grupo Bio-Oss®. 4X (HE)

Figura 75 - BoneCeramic ${ }^{\circledR}$, período de 8 semanas. Maior quantidade de (ON) circundando as partículas (BO) comparado aos outros períodos. Presença de partículas inteiras com algumas microfraturas e porosidades na superfície. 10X (AT)

Figura 76 - OsteoScaf ${ }^{\mathrm{TM}}$, período de 8 semanas. Partículas (OS) bastante biodegradadas e sendo substituídas por ON. 10X (AT).....

Figura 77 - BoneCeramic $®$, período de 8 semanas. Integridade da MS e sua relação com as partículas (BO). Partículas (BO) permaneceram com seu formato original demonstrando ausência de degradação com 8 semanas. A. 4X (HE); B. 4X (AT)

Figura 78 - BoneCeramic $\AA$, período de 4 semanas. Presença de ON circundando as partículas (BO) com maior frequência nas áreas periféricas. A. 4X (HE); B. 10X (AT).

Figura 79 - OsteoScaf ${ }^{\mathrm{TM}}$, período de 8 semanas. A. Detalhe de partículas (OS) ainda não totalmente biodegradadas circundadas em várias regiões por ON. 10X (AT), B. 10X (HE)

Figura 80 - OsteoScaf ${ }^{\mathrm{TM}}$, período de 4 semanas. A. As partículas (OS) apresentaram biodegradação e menor quantidade de ON circundando-as comparada ao período de 8 semanas 10X (AT); B. 4X (HE)

Figura 81 - OsteoScaf ${ }^{\mathrm{TM}}$, período de 2 semanas. Maior quantidade de partículas (OS) e menor de ON comparado aos outros períodos A. 4X (HE) e B. 10X (HE)

Figura 82 - Osso autógeno, período de 8 semanas. Grande quantidade de células de gordura preenchendo os espaços vazios, após reabsorção óssea. 4X (AT)

Figura 83 - BoneCeramic ${ }^{\circledR}$, período de 8 semanas. Detalhe das células gigantes envolvendo as partículas (BO). A. 10X (AT); B. $10 \mathrm{X}(\mathrm{HE})$ 

Figura 84 - Gráficos ilustrando a evolução da marcação por tetraciclina, nos campos avaliados, por grupo, em cada período. OS: OsteoScaf ${ }^{\mathrm{TM}}$, BI: Bio-Oss ${ }^{\circledR}, \mathrm{BO}$ : BoneCeramic ${ }^{\circledR}$ e AU: osso autógeno.

Figura 85 - Gráficos ilustrando a marcação por tetraciclina, nos diferentes campos ou áreas do levantamento de seio maxilar, em cada período. OS: OsteoScaf ${ }^{\mathrm{TM}}$, BI: Bio-Oss®, BO: BoneCeramic $\circledR^{\text {e }}$ AU: osso autógeno

Figura 86 - Gráficos ilustrando a evolução da marcação por alizarina nos campos avaliados, por grupo, em cada período. OS: OsteoScaf $^{\mathrm{TM}}$, BI: Bio-Oss ${ }^{\circledR}, \mathrm{BO}$ : BoneCeramic ${ }^{\circledR}$ e AU: osso autógeno.

Figura 87 - Gráficos ilustrando a marcação por alizarina nos diferentes campos ou áreas do levantamento de seio maxilar, em cada período. OS: OsteoScaf ${ }^{\mathrm{TM}}, \quad \mathrm{BI}: \quad$ Bio-Oss ${ }^{\circledR}, \quad$ BO: BoneCeramic ${ }^{\circledR}$ e AU: osso autógeno

Figura 88 - A. Gráfico ilustrando a marcação por calceína nos diferentes campos ou áreas do levantamento de seio maxilar, no período de 8 semanas. B. Média dos campos da marcação por calceína. OS: OsteoScaf ${ }^{\mathrm{TM}}$, BI: Bio-Oss ${ }^{\circledR}, \quad$ BO: BoneCeramic $®$ e AU: osso autógeno

Figura 89 - Gráficos ilustrativos da expressão de mRNA para COL1A1. A. Evolução da expressão de mRNA para COL1A1, por grupo, ao longo do tempo. B. Expressão de mRNA para COL1A1, por grupo, no período de 2 semanas. C. Expressão de mRNA para COL1A1, por grupo, no período de 4 semanas. D. Expressão de mRNA para COL1A1, por grupo, no período de 8 semanas. OS: OsteoScaf ${ }^{\mathrm{TM}}$, BI: Bio-Oss ${ }^{\circledR}$, BO: BoneCeramic ${ }^{\circledR}$ e AU: osso autógeno .

Figura 90 - Gráficos ilustrativos da expressão de mRNA para VEGF. A. Evolução da expressão de mRNA para VEGF, por grupo, ao longo do tempo. B. Expressão de mRNA para VEGF, por grupo, no período de 2 semanas. C. Expressão de mRNA para VEGF, por grupo, no período de 4 semanas. D. Expressão de mRNA para VEGF, por grupo, no período de 8 semanas. OS: OsteoScaf ${ }^{\mathrm{TM}}$, BI: Bio-Oss ${ }^{\circledR}, \mathrm{BO}$ : BoneCeramic ${ }^{\circledR}$ e AU: osso autógeno. 

Figura 91 - Gráficos ilustrativos da expressão de mRNA para RUNX2. A. Evolução da expressão de mRNA para RUNX2, por grupo, ao longo do tempo. B. Expressão de mRNA para RUNX2, por grupo, no período de 2 semanas. C. Expressão de mRNA para RUNX2, por grupo, no período de 4 semanas. D. Expressão de mRNA para RUNX2, por grupo, no período de 8 semanas. OS: OsteoScaf ${ }^{\mathrm{TM}}$, BI: Bio-Oss ${ }^{\circledR}$, BO: BoneCeramic $®$ e AU: osso autógeno

Figura 92 - Gráficos ilustrativos da expressão de mRNA para BMP-2. A. Evolução da expressão de mRNA para BMP2, por grupo, ao longo do tempo. B. Expressão de mRNA para BMP-2, por grupo, no período de 2 semanas. C. Expressão de mRNA para BMP-2, por grupo, no período de 4 semanas. D. Expressão de mRNA para BMP-2, por grupo, no período de 8 semanas. OS: OsteoScaf ${ }^{\mathrm{TM}}, \mathrm{BI}$ : Bio-Oss ${ }^{\circledR}, \mathrm{BO}$ : BoneCeramic ${ }^{\circledR}$ e AU: osso autógeno 180

Figura 93 - Gráficos ilustrativos da expressão de mRNA para SPARC. A. Evolução da expressão de mRNA para SPARC, por grupo, ao longo do tempo. B. Expressão de mRNA para SPARC, por grupo, no período de 2 semanas. C. Expressão de mRNA para SPARC, por grupo, no período de 4 semanas. D. Expressão de mRNA para SPARC, por grupo, no período de 8 semanas. OS: OsteoScaf ${ }^{\mathrm{TM}}, \mathrm{BI}$ : Bio-Oss ${ }^{\circledR}, \mathrm{BO}$ : BoneCeramic ${ }^{\circledR}$ e AU: osso autógeno

Figura 94 - Gráficos ilustrativos da expressão de mRNA para ALPL. A. Evolução da expressão de mRNA para ALPL, por grupo, ao longo do tempo. B. Expressão de mRNA para ALPL, por grupo, no período de 2 semanas. C. Expressão de mRNA para ALPL, por grupo, no período de 4 semanas. D. Expressão de mRNA para ALPL, por grupo, no período de 8 semanas. OS: OsteoScaf $^{\mathrm{TM}}$, BI: Bio-Oss ${ }^{\circledR}, \mathrm{BO}$ : BoneCeramic ${ }^{\circledR}$ e AU: osso autógeno. 



\section{LISTA DE TABELAS}

Tabela 1 - Quantidade de espécimes por grupo e período submetidas a quantificação dos 6 marcadores descritos abaixo

Tabela 2 - Resultados da análise qualitativa realizada nas TCFC....

Tabela 3 - Média e desvio-padrão do VT em mm3, por grupo, em cada período estudado. Os dados foram analisados estatisticamente entre os grupos, por período e entre os períodos, por grupo, empregando-se os testes de variância ANOVA a dois critérios e teste de Tukey

Tabela 4 - Resultados da análise de variância (ANOVA) a 2 critérios para o VT

Tabela 5 - Resultados da comparação entre grupos. Teste de Tukey para o VT.

Tabela 6 - Resultados da comparação entre períodos. Teste de Tukey para o VT

Tabela 7 - Média e desvio-padrão do VO neoformado em $\mathrm{mm}^{3}$, por grupo, em cada período estudado. Os dados foram analisados estatisticamente entre os grupos, por período e entre os períodos, por grupo, empregando-se os testes de variância ANOVA a dois critérios e teste de Tukey

Tabela 8 - Resultados da análise de variância (ANOVA) a 2 critérios para o VO

Tabela 9 - Resultados da comparação entre grupos. Teste de Tukey para o VO

Tabela 10 - Média e desvio-padrão da relação do VO/VT, por grupo, em cada período estudado. Os dados foram analisados estatisticamente entre os grupos, por período e entre os períodos, por grupo, empregando-se os testes de variância ANOVA a dois critérios e teste de Tukey

Tabela 11 - Resultados da análise de variância (ANOVA) a 2 critérios para a relação VO/VT

Tabela 12 - Resultados da interação. Teste de Tukey para a relação $\mathrm{VO} / \mathrm{VT}$..... 

Tabela 13 - Média e desvio-padrão do NT, por grupo, em cada período estudado. Os dados foram analisados estatisticamente entre os grupos, por período e entre os períodos, por grupo, empregando-se os testes de variância ANOVA a dois critérios e teste de Tukey

Tabela 14 - Resultados da análise de variância (ANOVA) a 2 critérios para o NT.

Tabela 15 - Resultados da comparação entre grupos. Teste de Tukey para o NT.

Tabela 16 - Média e desvio-padrão da ET em mm, por grupo, em cada período estudado. Os dados foram analisados estatisticamente entre os grupos, por período e entre os períodos, por grupo, empregando-se os testes de variância ANOVA a dois critérios e teste de Tukey

Tabela 17 - Resultados da análise de variância (ANOVA) a 2 critérios para a ET

Tabela 18 - Resultados da comparação entre grupos. Teste de Tukey para a ET

Tabela 19 - Média e desvio padrão da ST em mm, por grupo, em cada período estudado. Os dados foram analisados estatisticamente entre os grupos, por período e entre os períodos, por grupo, empregando-se os testes de variância ANOVA a dois critérios e teste de Tukey

Tabela 20 - Resultados da análise de variância (ANOVA) a 2 critérios para o ST

Tabela 21 - Resultados da comparação entre grupos. Teste de Tukey para o ST

Tabela 22 - Média e desvio-padrão da expressão da marcação de tetraciclina em \%, nos 3 campos avaliados, por grupo, em cada período estudado. Os dados foram analisados estatisticamente entre os campos, grupos e entre os períodos, empregando-se os testes de variância ANOVA a três critérios e teste de Tukey.

Tabela 23 - Resultados da análise de variância (ANOVA) a 3 critérios para a expressão da marcação de tetraciclina

Tabela 24 - Resultados da comparação entre períodos. Teste de Tukey para a expressão da marcação de tetraciclina 

Tabela 25 - Média e desvio-padrão da expressão da marcação por alizarina em \%, nos 3 campos avaliados, por grupo, em cada período estudado. Os dados foram analisados estatisticamente entre os campos, grupos e entre os períodos, empregando-se os testes de variância ANOVA a três critérios e teste de Tukey.....

Tabela 26 - Resultados da análise de variância (ANOVA) a 3 critérios para a expressão da marcação por alizarina.....

Tabela 27 - Resultados da comparação entre campos. Teste de Tukey para a expressão da marcação por alizarina.

Tabela 28 - Média e desvio-padrão da expressão da marcação por calceína nos 3 campos avaliados, por grupo, no período de 8 semanas. Os dados foram analisados estatisticamente entre os campos, grupos e entre os períodos, empregando-se os testes de variância ANOVA a três critérios e teste de Tukey .....

Tabela 29 - Resultados da análise de variância (ANOVA) a 2 critérios para a expressão da marcação por calceína

Tabela 30 - Resultados da comparação entre campos para a expressão da marcação por calceína

Tabela 31 - Variável COL1A1. Resultados dos valores da expressão de mRNA para o gene alvo, obtidos de cada animal por grupo, em cada período

Tabela 32 - Variável VEGF. Resultados dos valores da expressão de mRNA para o gene alvo, obtidos de cada animal por grupo, em cada período

Tabela 33 - Variável RUNX2. Resultados dos valores da expressão de mRNA para o gene alvo, obtidos de cada animal por grupo, em cada período

Tabela 34 - Variável BMP-2. Resultados dos valores da expressão de mRNA para o gene alvo, obtidos de cada animal por grupo, em cada período

Tabela 35 - Variável SPARC. Resultados dos valores da expressão de mRNA para o gene alvo, obtidos de cada animal por grupo, em cada período

Tabela 36 - Variável ALPL. Resultados dos valores da intensidade de expressão de mRNA para o gene alvo, obtidos de cada animal por grupo em cada período 



\section{LISTA DE ABREVISTURAS, SIGLAS E SIMBOLOS}

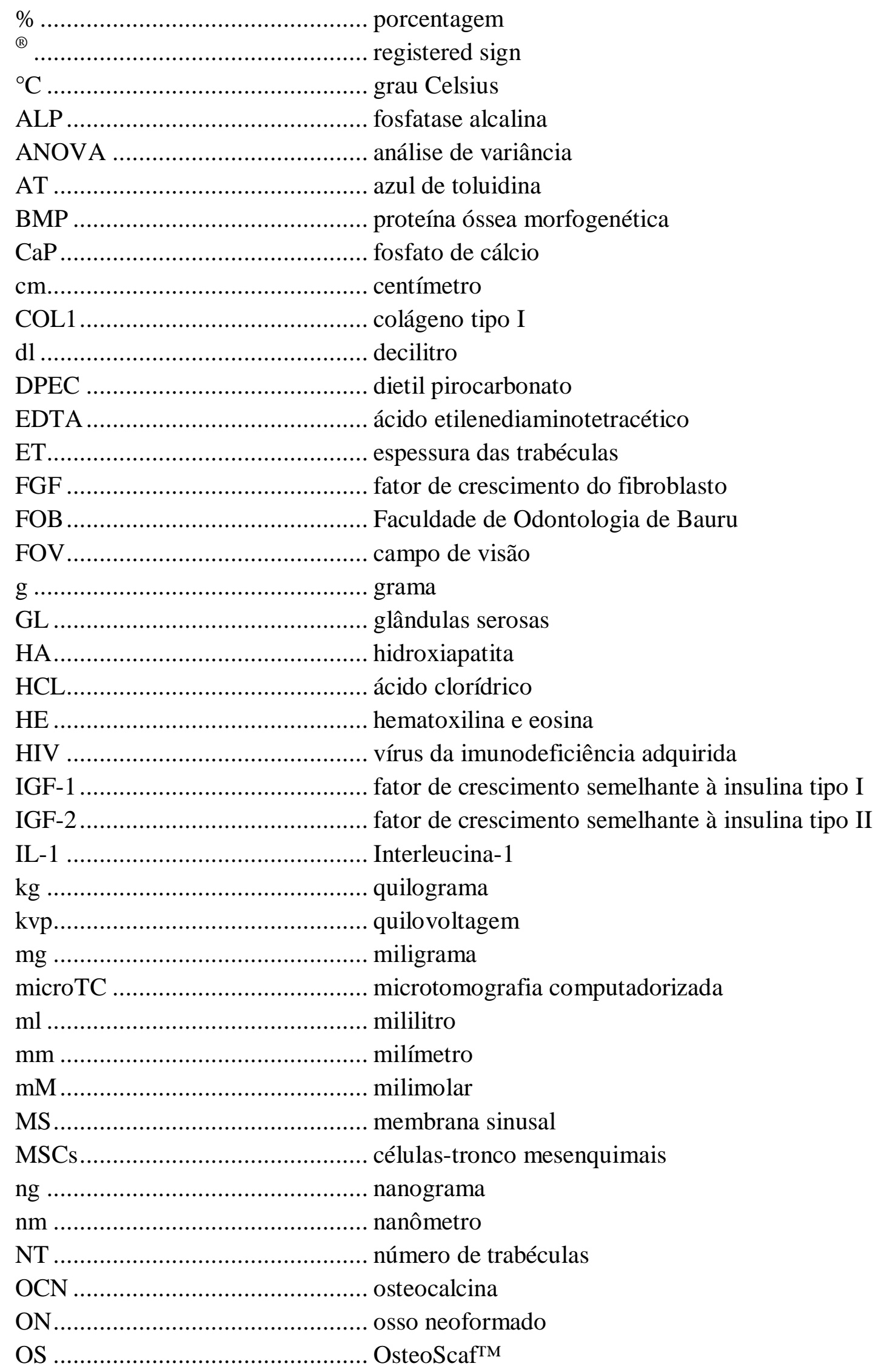





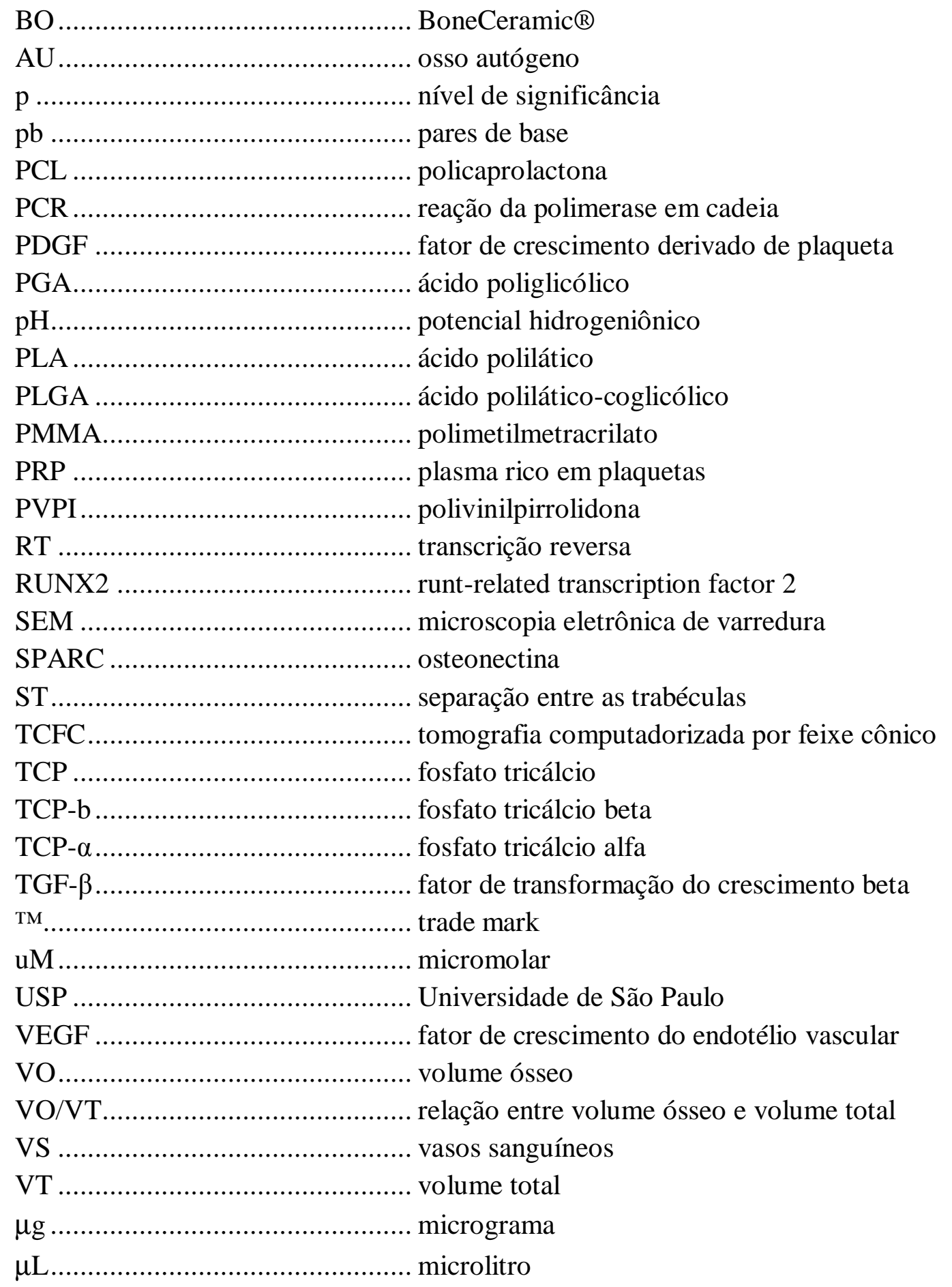





\section{SUMARIO}

REVISÃO DE LITERATURA. 33

2.1 CONSIDERAÇÕES INICIAIS

ENXERTO OSSEO E SEUS SUBSTITUTOS UTILIZADOS

NO LEVANTAMENTO DE SEIO MAXILAR ....

2.2.1 Enxerto Ósseo - Definição e características ........................................................ 39

2.2.2 Classificação do Enxerto Ósseo ................................................................ 40

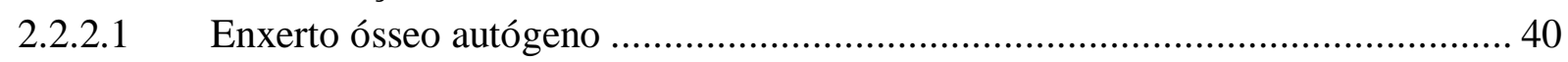

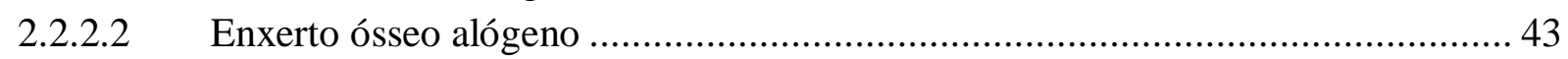

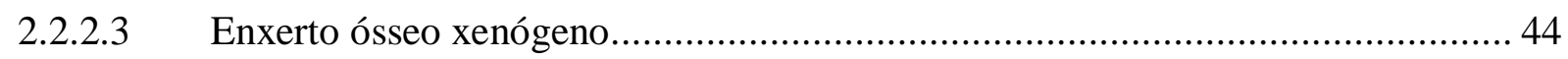

2.2.3 Substitutos Ósseos - Classificação ................................................................. 44

2.2.3.1 Substitutos ósseos originados de osso alógeno ou implante ósseo

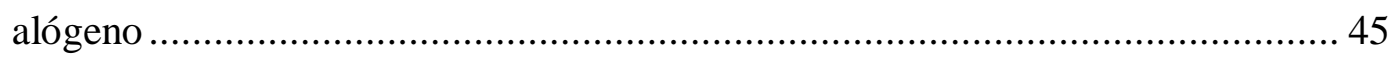

2.2.3.2 Substitutos ósseos originados de osso xenógeno ou implante

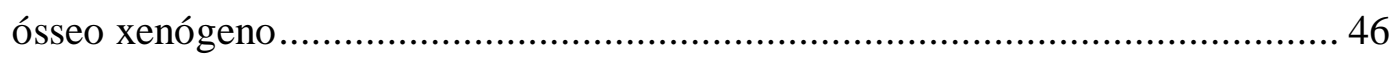

2.2.3.3 Substitutos ósseos compostos de cerâmica .................................................. 49

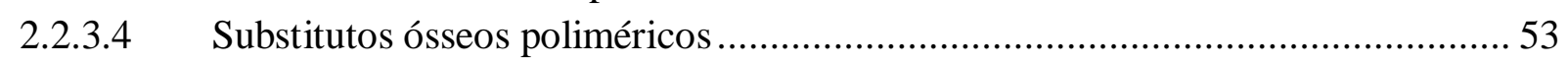

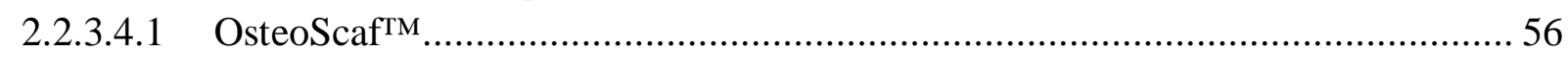

MATERIAL E MÉTODOS.................................................................................. 67

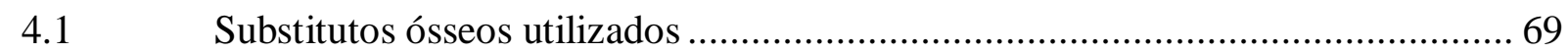

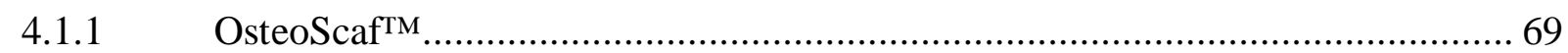

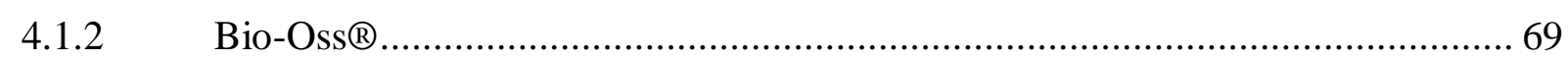

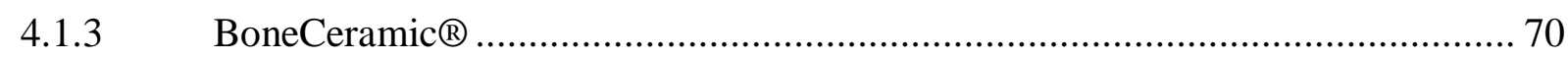

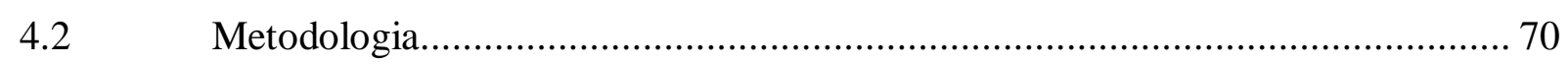

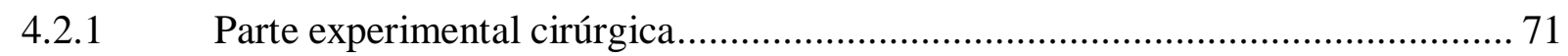

4.2.1.1 Preparo da área doadora e remoção do enxerto................................................ 71

4.2.1.2 Preparo da área receptora: Levantamento do seio maxilar ................................. 75

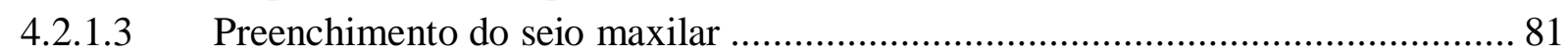

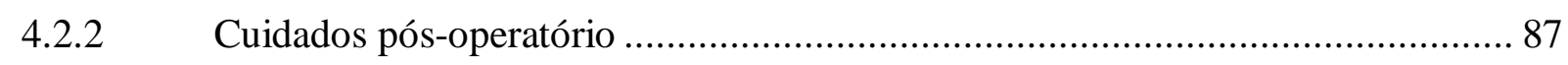

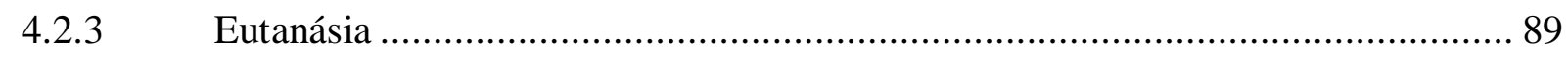

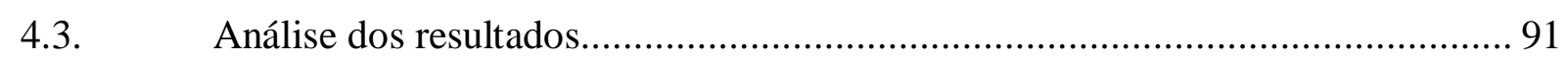

4.3.1 Análise através de tomografias computadorizadas por feixe

4.3.2 Análise microtomográfica ....................................................................... 93

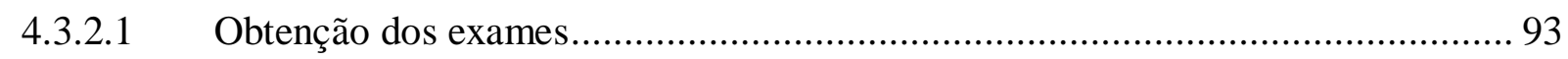

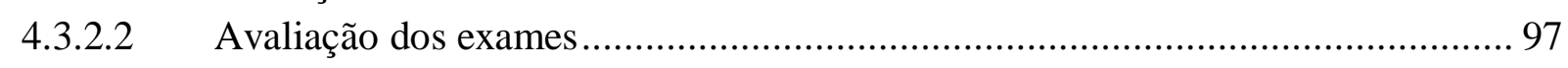

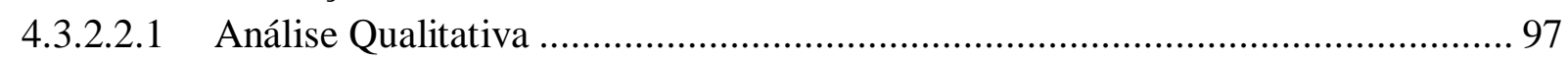





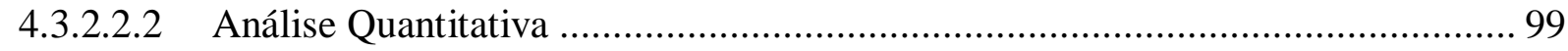

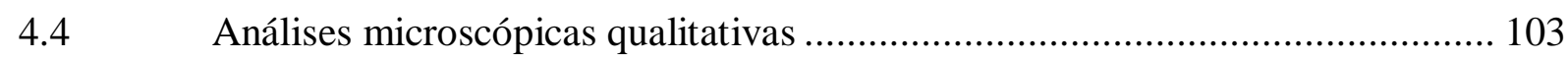

4.4.1 Desidratação e inclusão das amostras em resina ........................................... 103

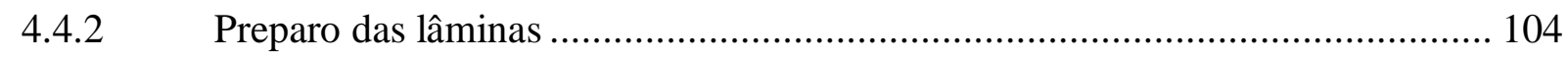

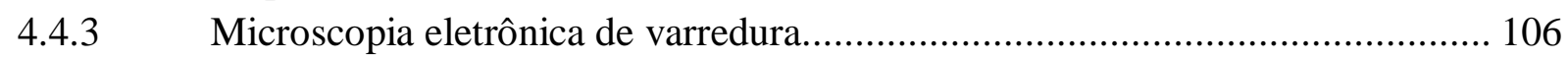

4.4.4 Análise qualitativa em microscópio óptico .................................................... 107

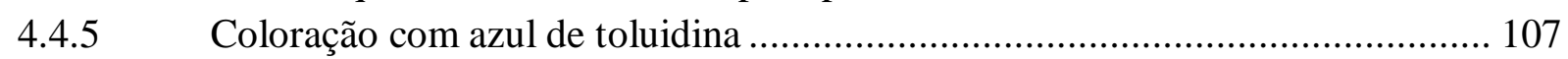

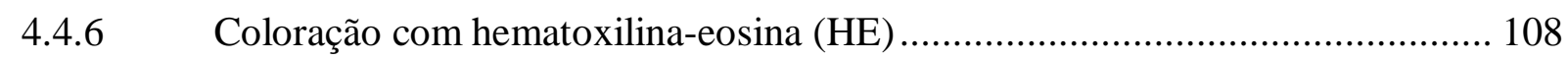

4.4.7 Análise quantitativa através de microscopia confocal .................................... 108

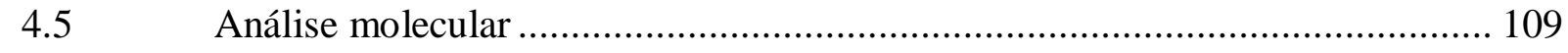

4.5.1 Extração de RNA e Transcrição Reversa.......................................................... 110

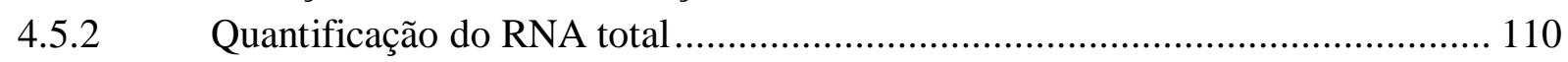

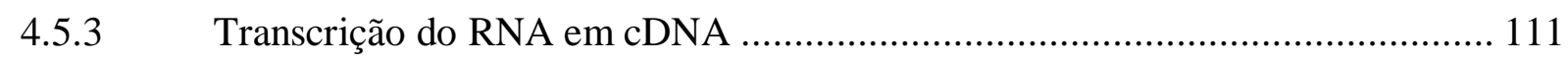

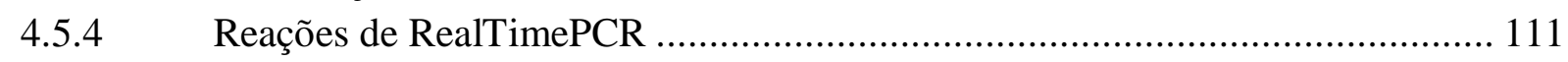

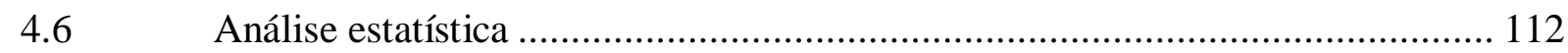

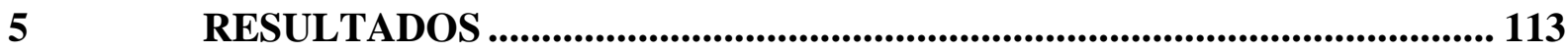

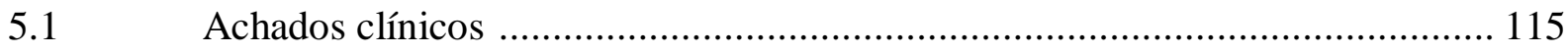

5.2 Análise das tomografias computadorizadas por feixe cônico

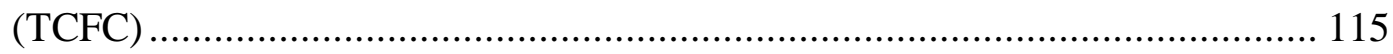

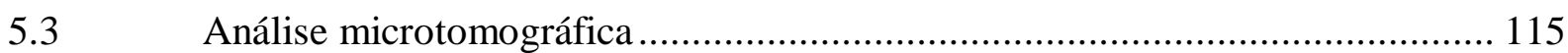

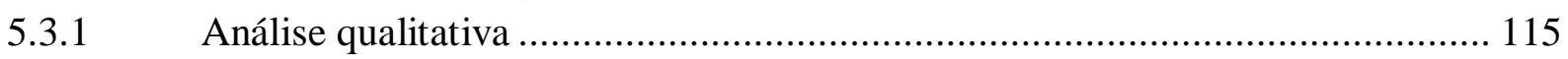

5.3.2 Análise quantitativa ........................................................................... 131

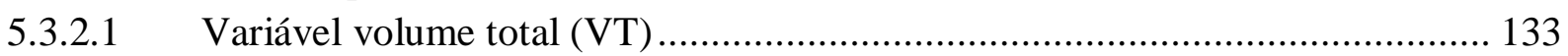

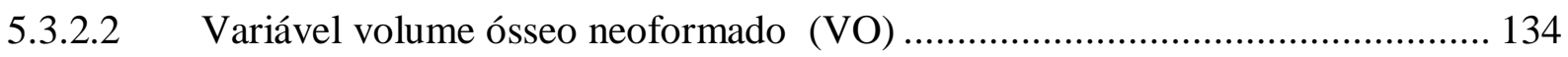

5.3.2.3. Variável relação volume ósseo neoformado/volume total

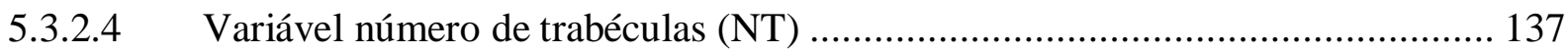

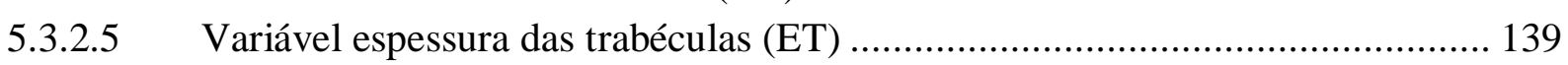

5.3.2.6 Variável separação entre as trabéculas (ST) ................................................. 140

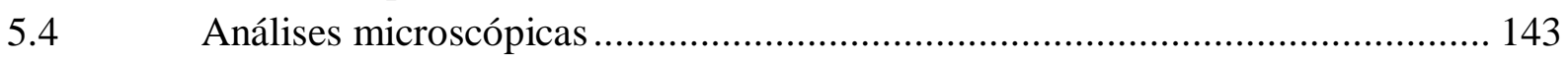

5.4.1 Análise qualitativa da microscopia eletrônica de varredura

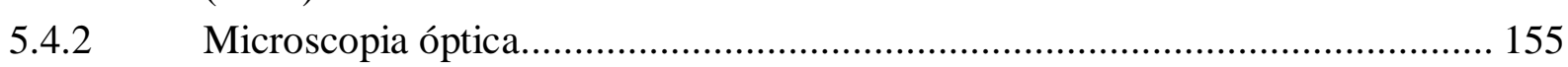

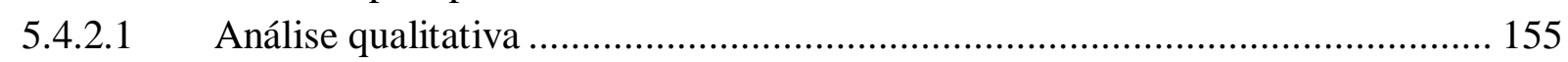

5.4.3 Análise quantitativa através de microscopia confocal .................................... 171

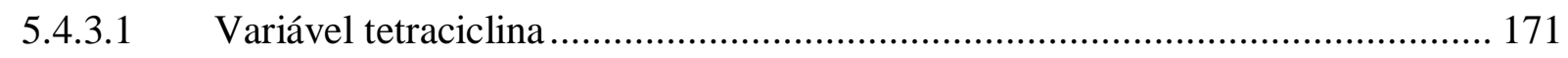

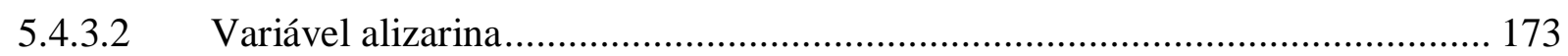

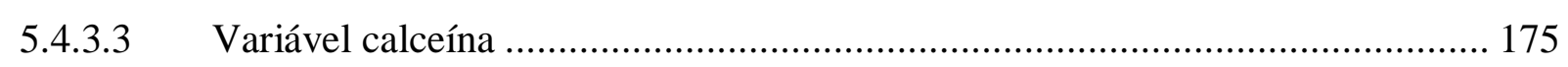

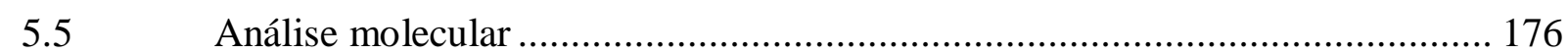

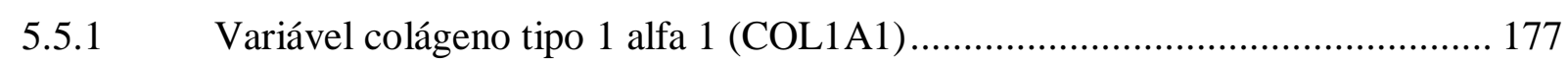

5.5.2 Variável fator de crescimento vascular endotelial (VEGF) .............................. 178

5.5.3 Variável runt-related transcription factor 2 (RUNX2) .................................. 179 

5.5.4 Variável proteína óssea morfogenética 2 (BMP-2) ....................................... 180

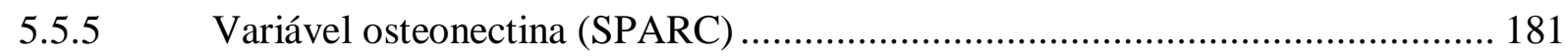

5.5.6 Variável fosfatase alcalina (ALPL) ........................................................ 182

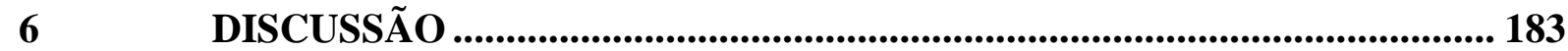

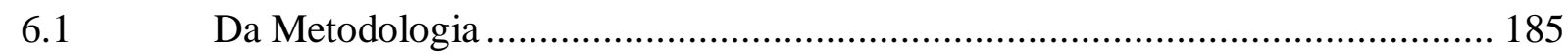

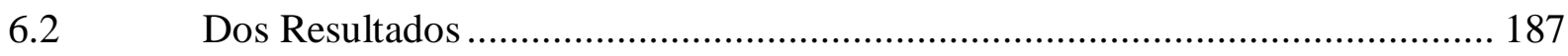

$7 \quad$ CONCLUSÃ

REFER̂ENCIAS...................................................................................... 199

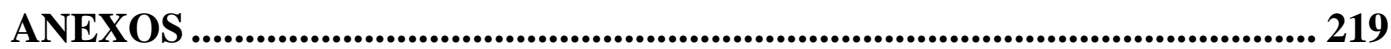





\section{INTRODUÇÃO}





\section{INTRODUÇÃO}

Atualmente, a falta de osso ainda é um dos grandes desafios para a reabilitação oral com implantes, o que dificulta ou limita essa alternativa de tratamento. Diante disso, cirurgias reconstrutivas são frequentemente realizadas, como recurso, para corrigir deficiências ósseas viabilizando a instalação dos implantes (UEDA; TOHNAI; NAKAI, 2001). O enxerto ósseo autógeno apresenta todas as propriedades desejáveis para essa finalidade, sendo considerado a melhor opção para o preenchimento dos defeitos ósseos. Entretanto, além da desvantagem relacionada à morbidade do local doador (intra ou extraoral), dependendo da cirurgia reconstrutiva e da quantidade necessária de enxerto ósseo, os procedimentos cirúrgicos podem exigir internação hospitalar e, consequentemente, um alto custo final do tratamento, limitando sua utilização. (SCHIMMING; SCHELZEISEN, 2004; RAGHOEBAR et al., 2001; JOSHI, 2004).

Diante dessas considerações sobre o osso autógeno, uma ampla variedade de biomateriais tem sido utilizada como substitutos ósseos. A questão é: qual biomaterial seria ideal para essa proposta? Estudos vêm sendo realizados no intuito de se obter um substituto ósseo com propriedades osteogênica e biomecânica ideais ou similares ao enxerto ósseo autógeno. Ainda não existe o substituto ósseo ideal, portanto, a busca continua através do desenvolvimento de novos produtos com essa finalidade.

Um material biocompatível e osteocondutor, formado pela união do ácido poliláticoco-glicólico (PLGA) com duas fases de fosfato de cálcio $(\mathrm{CaP})$ e uma camada mais externa de $\mathrm{CaP}$, de 3 a $5 \mu \mathrm{m}$ de espessura, foi desenvolvido e seu nome comercial é OsteoScaf ${ }^{\mathrm{TM}}$ (BoneTec Corp - TRT, Toronto, Canadá) (LICKORISH; GUAN; DAVIES, 2007; GUAN; DAVIES, 2004). O OsteoScaf ${ }^{\mathrm{TM}}($ BoneTec Corp - TRT, Toronto, Canadá) apresenta resistência mecânica suficiente para manipulação cirúrgica e pode ser facilmente fabricado, conforme a forma e a porosidade desejadas. Estudos revelaram se tratar de uma matriz trifásica, com macroporos altamente interconectados, totalmente biodegradável (LICKORISH; GUAN; DAVIES, 2007; GUAN; DAVIES, 2004). Matrizes tridimensionais feitas desse material, com porosidade similar ao osso trabecular humano, têm mostrado crescimento ósseo tanto in vitro como in vivo e oferecem grande potencial para aplicação em bioengenharia (CANCEDDA et al., 2003; JABBARZADEH et al., 2008; KARP; SHOICHET; DAVIES, 2003; ISHAUG-RILEY et al., 1997; HOLY; SHOICHET; DAVIES, 
2000). Alguns estudos em animais revelaram biocompatibilidade, osteoindução e osteocondução na utilização dessas matrizes (SHEA et al., 2000; FIALKOV et al., 2003; GOMI et al., 2004; KARP et al., 2003; SALGADO et al., 2007).

Apenas um trabalho apresentou a utilização do OsteoScaf ${ }^{\mathrm{TM}}$ (BoneTec Corp - TRT, Toronto, Canadá) em cirurgias de levantamento de seio maxilar através de um caso clínico bem sucedido e nenhum trabalho o comparou com outros substitutos ósseos. Aliado ao interesse de analisar detalhadamente o comportamento biológico do OsteoScaf ${ }^{\mathrm{TM}}$ (BoneTec Corp - TRT, Toronto, Canadá) em cirurgia de levantamento de seio maxilar, considerou-se interessante a proposta de compará-lo, através de um modelo experimental bem definido, com outros substitutos ósseos não totalmente biodegradáveis e que estão disponíveis comercialmente para a mesma finalidade. 
2 REVISÃO DE LITERATURA 



\section{REVISÃO DE LITERATURA}

\subsection{CONSIDERAÇÕES INICIAIS}

Ao longo dos últimos 40 anos, a osseointegração tem sido considerada a maior descoberta científica para a odontologia, desde sua primeira descrição oferecendo uma alternativa de reabilitação oral aos desdentados, através de implantes (BRANEMARK et al., 1977), os quais estão cada dia mais acessíveis mundialmente, especialmente, para a população brasileira. Entretanto, existem algumas limitações individuais, dentre elas a insuficiência óssea nos maxilares, comum após a perda dos dentes e a ausência de estímulo funcional na região (CAWOOD, 1988; IRINAKIS, 2006; VAN DER WEIJDEN; DELL'ACQUA; SLOT, 2009; REICH et al., 2011). A deficiência de volume ósseo na região posterior da maxila é um dos problemas mais comuns encontrado pelos implantodontistas e protesistas ao planejar uma reabilitação suportada por implantes nessa região. Isso porque o seio maxilar, na ausência dos dentes, tende a se pneumatizar, tornando a altura do rebordo alveolar reduzida, impossibilitando a instalação e/ou a estabilidade inicial dos implantes requeridos para o suporte protético (CHANAVAZ, 1990; JENSEN; KRANTZ-SIMONSEN; SINDETPEDERSEN, 1990; JEMT; LEKHOLM, 1993; WHEELER, 1997).

Diante desse problema, autores criaram um procedimento para aumentar o volume ósseo de maxilas atróficas através do levantamento da membrana sinusal ou Schneideriana, seguido pelo preenchimento com um enxerto entre esta e o rebordo alveolar, diminuindo o espaço sinusal e aumentando o volume ósseo da região (BOYNE; JAMES, 1980; TATUM, 1986). A primeira descrição detalhada desse procedimento foi em 1980, por Boyne, embora Tatum, previamente, já houvesse realizado o mesmo procedimento, o qual foi apresentado num encontro científico em 1976, na cidade de Birmingham, Alabama (BOYNE; JAMES, 1980; TATUM, 1986; VAN DER BERGH et al., 2000). A técnica se caracterizava pela criação de uma janela óssea na parede lateral do seio maxilar, via incisão em fundo de sulco, utilizando broca esférica em baixa rotação e, em seguida, a elevação cuidadosa da mucosa sinusal com cureta e o preenchimento do espaço criado com osso autógeno particulado removido da crista ilíaca (BOYNE; JAMES, 1980; TATUM, 1986). Tatum (1986) também descreveu cinco tipos de incisões, três tipos de acesso, o uso de osso autógeno, homógeno e aloplástico, todos relacionados ao procedimento de levantamento de seio maxilar. Além disso, 
o autor descreveu o procedimento de levantamento de seio maxilar e a instalação do implante em um e dois estágios cirúrgicos (TATUM, 1986).

O procedimento de levantamento de seio maxilar é indicado quando a altura óssea residual impossibilita a instalação de implantes ou a realização de técnicas de levantamento de seio maxilar utilizando osteótomos. Até $5 \mathrm{~mm}$ de altura óssea, é possível a instalação de implantes simultaneamente ao levantamento de seio maxilar, porém, quando a altura for inferior a 5mm, é recomendada a instalação dos implantes, no mínimo, 6 meses após a realização do levantamento de seio maxilar, devido à ausência de estabilidade primária do implante nas condições ósseas já descritas (TOSOULIS; YAO; FINE, 2011). Atualmente, existem muitas modificações de técnica relacionadas ao acesso, instrumentos e biomateriais utilizados no preenchimento, porém a técnica de levantamento de seio maxilar através da criação de uma janela na parede lateral do seio maxilar, com acesso vestibular, tem sido amplamente utilizada e é considerada confiável, principalmente, quando o preenchimento se dá com o osso autógeno (RAJA, 2009). Nem todos os casos podem ser tratados através desse tipo de cirurgia reconstrutiva. Pacientes fumantes, portadores de doenças sistêmicas, presença de sinusites aguda, crônica ou outras patologias nos seios maxilares são exemplos de contraindicações (CANULLO; DELLAVIA, 2009).

Além das complicações que acometem qualquer tipo de intervenção cirúrgica (hematoma, sensibilidade dos dentes adjacentes, lesão em nervos, edema, deiscência da mucosa), a perfuração da membrana sinusal ou Scheneideriana é a mais comum (10\% a 34\%) nesse tipo de procedimento, passível de insucesso quando não protegida (SOMANATHAN; SIMUNEK, 2006; TOSOULIS; YAO; FINE, 2011). Além disso, dependendo dos cuidados trans e pós-cirúrgicos, infecção pode ocorrer nos seios maxilares, do mesmo modo que no enxerto ou biomaterial utilizado para seu preenchimento (CORREIA et al., 2012).

Na literatura, o enxerto ósseo autógeno é considerado como "gold standard", ou seja, a melhor qualidade para o preenchimento dos defeitos ósseos, pois apresenta as características consideradas ideais: osteogênese, osteoindução e osteocondução (TONG et al., 1998). Entretanto, as técnicas de enxerto ósseo e de reconstrução parcial dos maxilares são planejadas de acordo com o grau de perda óssea, planejamento cirúrgico protético, das condições gerais do paciente e da viabilidade da área doadora (RAGHOEBAR et al., 2001). A grande limitação da utilização do enxerto ósseo autógeno intraoral (ramo mandibular, mento, túber da maxila e exostoses) é a necessidade de mais intervenções cirúrgicas e a morbidade do local doador, além da limitação da quantidade de osso autógeno (RAGHOEBAR et al., 2001; SCHIMMING; SCHELZEISEN, 2004; JOSHI, 2004). As áreas doadoras extraorais (crista 
ilíaca e calota craniana por exemplo) também apresentam algumas desvantagens ou limitações como a necessidade de internação hospitalar, morbidade da área doadora, maior custo e, particularmente, no caso da crista ilíaca, um pós-operatório mais arriscado em relação a infecções, injúrias a nervos e deficiência funcional (YOUNGER; CHAPMAN, 1989). Além dessas limitações mencionadas, existem relatos de níveis significantes de reabsorção óssea quando o osso autógeno é utilizado, requerendo uma consideração alternativa dos substitutos ósseos (ARAUJO et al., 2002; SBORDONE et al., 2009; ZIJDERVELD et al., 2009; CORDARO et al., 2010).

Como prioridade de minimizar a morbidade ao paciente, os substitutos ósseos vêm sendo cada vez mais elaborados e melhorados. Estudos demonstraram sua eficácia comparável à utilização do enxerto ósseo autógeno (ARAUJO et al., 2002; SBORDONE et al., 2009; ZIJDERVELD et al., 2009; CORDARO et al., 2010; ESPOSITO et al., 2009; ESPOSITO et al., 2010). Eles podem ter origens homógena, xenógena ou sintética, constituídos de um material como base principal (LAURECIN; KHAN; EL-AMIN, 2006). Diante dessa ampla variedade, muitas vezes é difícil o cirurgião eleger o melhor produto. Critérios essenciais incluem: auxiliar o reparo ósseo, apresentar biocompatibilidade, não deixar sequelas pós-operatórias e receber a aceitação pelo paciente. A relação entre o custo e o benefício, acesso e manuseabilidade também são critérios considerados na seleção do substituto ósseo (WHEELER, 1997; MOORE; GRAVES; BAIN, 2001).

Diante da existência de trabalhos de revisão de literatura sistemática atuais sobre o procedimento de levantamento de seio maxilar (TAN et al., 2008; PJETURSSON et al., 2008; NKENKE; STELZLE, 2009; ESPOSITO et al., 2009; ESPOSITO et al., 2010; CORREIA et al., 2012), inclusive abordando resultados após a instalação de implantes, o objetivo de revisar a literatura sobre esse tópico não foi proposto. Além disso, existe uma dificuldade em analisar os estudos diante da grande variabilidade nos desenhos, diferentes tipos de implantes utilizados, diferença no tempo de acompanhamento, falta de detalhes sobre a carga funcional dos implantes em cada paciente e, ainda, a diversidade dos biomateriais utilizados como substitutos ósseos. Autores realizaram um estudo sistemático avaliando estudos em humanos e, de 1028 títulos previamente selecionados, apenas 21 preencheram os critérios de inclusão, os quais respeitaram um alto nível de evidência científica (NKENKE; STELZLE, 2009). O autor concluiu que as evidências não suportam nem refutam a superioridade do osso autógeno sobre os substitutos ósseos, considerando os resultados de sobrevida de implante e as complicações (NKENKE; STELZLE, 2009). 
Uma revisão recente sobre a utilização de substitutos ósseos em levantamento de seio maxilar foi realizada somente avaliando modelos animais (BROWAEYS; BOUVRY; DE BRUYN, 2007). O autor considerou 26 trabalhos e encontrou 40\% de reabsorção óssea quando o osso autógeno foi utilizado na ausência de carga funcional (BROWAEYS; BOUVRY; DE BRUYN, 2007). Ainda, outros autores acreditam que o enxerto ósseo autógeno apresenta uma tendência para a reabsorção, principalmente originado de áreas doadoras extraorais (BARONE et al., 2005; PIKDÖKEN et al., 2011). A respeito dos substitutos ósseos, os autores sugerem que a osseointegração inicial parece ser independente do tipo de biomaterial aplicado como enxerto. Além disso, a qualidade dos estudos avaliados foi considerada muito pobre e sem análises estatísticas (BROWAEYS; BOUVRY; DE BRUYN, 2007). Uma revisão clínica randomizada, sobre técnicas e uso de substitutos ósseos em levantamento de seio maxilar, demonstrou a presença de poucos estudos e com curto período de proservação. Porém concluiu, através de 29 trabalhos, que os substitutos ósseos podem ser utilizados com bastante sucesso para essa finalidade (EPOSITO, et al., 2010). O mesmo autor, em duas revisões sistemáticas para a Cochrane, considerou que o uso de substitutos ósseos é preferível aos enxertos ósseos autógenos (ESPOSITO et al., 2009; ESPOSITO et al., 2010). Segundo a revisão dos autores, Bio-Oss® (Geistlisch Farmacêutica, Wolhusen, Suíça) e Cerasorb® (Riemser Inc, Durham, NC, EUA) demonstraram ser semelhantes quanto à eficácia (ESPOSITO et al., 2009; ESPOSITO et al., 2010).

Por fim, após essa abordagem inicial geral, na tentativa de contextualizar o leitor sobre o assunto deste trabalho, este capítulo foi organizado em mais três tópicos principais relacionados aos enxertos e/ou substitutos ósseos, os quais alguns foram analisados neste trabalho. A eleição desses tópicos teve como objetivo informar o leitor sobre a classificação dos substitutos ósseos, além de citar alguns dos principais trabalhos da literatura utilizando-os em cirurgias de levantamento de seio maxilar. 


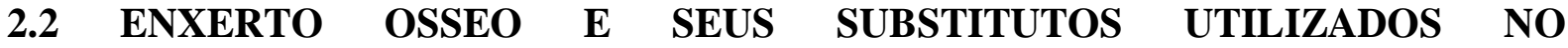 LEVANTAMENTO DE SEIO MAXILAR}

\subsubsection{Enxerto Ósseo - Definição e características}

Neste trabalho, o termo enxerto foi aplicado apenas ao osso autógeno, seguindo a definição correta de enxerto, correspondente ao transplante de células vivas, as quais sobrevivem após serem removidas de uma área doadora e são capazes de crescer em uma nova área receptora (MUSCHLER; LANE, 1992; STEVENSON, 1999; ARAUJO-PIRES, 2010). Para qualquer outro biomaterial aplicado com essa finalidade seria correto denominarmos implantes, pois os mesmos não possuem células vivas. Entretanto, para que não haja confusão com os implantes osseointegráveis, os termos substitutos ósseos ou biomateriais foram utilizados, neste trabalho, para se referir aos outros produtos utilizados como material para preenchimento. Portanto, no caso da técnica de levantamento de seio maxilar, o único enxerto utilizado, de fato, é o osso autógeno. No caso do osso alógeno, diante da necessidade de remoção da sua parte vital, ele é classificado como um implante ósseo alógeno. Os enxertos xenógenos seguem essa regra, somente são utilizados desvitalizados e, portanto, denominados implantes ósseos xenógenos (MUSCHLER; LANE, 1992; ARAUJO-PIRES, 2010 ).

Existem quatro características principais, consideradas ideais no auxílio à regeneração óssea, as quais ao menos uma delas o enxerto ou os substitutos ósseos devem apresentar (MOORE; GRAVES; BAIN, 2001; LAURECIN; KHAN; EL-AMIN, 2006). A primeira é a de possuir uma osteogenicidade ou atividade osteogênica, que é a capacidade de neoformação óssea a partir de células vivas presentes no enxerto, ou seja, os osteoblastos ou préosteoblastos viáveis, oriundos da área doadora do enxerto, são capazes de gerar a proliferação celular e produzir novo osso. A segunda propriedade é a osteocondutividade, que é a capacidade de o enxerto suportar ou permitir a migração de células, formação de vasos sanguíneos e o crescimento ósseo em sua superfície. A terceira é a osteoindutividade, caracterizada pela habilidade de induzir a diferenciação de células mesenquimais indiferenciadas ou células osteoprogenitoras oriundas do enxerto em células (osteoblastos) capazes de formar novo osso (STEVENSON, 1999; MOORE; GRAVES; BAIN, 2001; LAURECIN; KHAN; EL-AMIN, 2006). Por último, a osseointegração, que é a capacidade do contato químico entre as superfícies ósseas sem a presença de tecido fibroso (MOORE; GRAVES; BAIN, 2001). É fundamental a presença de pelo menos uma das características 
descritas acima. Somente o osso autógeno apresenta todas elas. Poucos osteoblastos são capazes de sobreviver ao transplante, porém um número adequado de células precursoras sobrevivem e o seu potencial osteogênico deriva delas (STEVENSON, 1999).

O implante alógeno pode ser osseointegrativo, osteocondutivo e pode exibir potencial osteoindutivo, entretanto não é osteogênico, pois não possui componente celular vivo. Substitutos ósseos sintéticos possuem apenas as propriedades de osseointegração e osteocondução (MOORE; GRAVES; BAIN, 2001).

Outras características consideradas ideais incluem: a remodelação do osso inicialmente formado em osso lamelar maduro, manutenção do osso maduro em função ao longo do tempo, habilidade de estabilizar implantes quando instalados simultaneamente com o procedimento de enxerto, baixo risco de infecção, boa disponibilidade, baixa antigenicidade e alto nível de confiabilidade (MUSCHLER; LANE, 1992; BLOCK; KENT, 1997; BOYCE; EDWARDS; SCARBOROUGH, 1999; PERRY, 1999; YILDIRIM et al., 2000; LUDWIG; KOWASKI; BODEN, 2000; APELT et al., 2004; GIANNOUDIS; DINOPOULOS; TSIRIDIS, 2005; TAMIMI et al., 2006; ARAUJO-PIRES, 2010). Outros autores consideram como características fundamentais serem imunologicamente inativos e fisiologicamente estáveis, não causar rejeição e ser idealmente reabsorvidos após a regeneração (CORREIA et al., 2012).

\subsubsection{Classificação do Enxerto Ósseo}

Seguindo a terminologia adequada para enxerto, a sua classificação foi dividida em:

\subsubsection{Enxerto ósseo autógeno}

O enxerto ósseo autógeno, autólogo ou autoenxerto é aquele removido de um local para o outro, no próprio indivíduo (STEVENSON, 1999). Pode ser particulado ou em bloco, removido das áreas intraorais (ramo mandibular, mento, túber da maxila e exostoses) ou extraorais (crista ilíaca, costela, calota craniana, tíbia). Áreas doadoras como o ramo mandibular e o túber da maxila são acessíveis e menos invasivas, mas são limitadas em volume ósseo, portanto, nos casos de severa reabsorção podem ser insuficientes (THORWARTH et al., 2005; CORREIA et al., 2012).

Áreas doadoras extraorais fornecem maior volume ósseo, porém causam maior morbidade e requerem ambiente hospitalar e anestesia geral para a sua realização (BARONE 
et al., 2005; SILVA; ALBERGARIA-BARBOSA; MAZZONETTO, 2006; ESPOSITO et al, 2010; CORREIA et al., 2012). As complicações relacionadas com as áreas doadoras intraorais também existem e são indesejáveis (RAGHOEBAR et al., 2001; SCHIMMING; SCHELZEISEN, 2004; JOSHI, 2004). O risco de lesão aos nervos mentoniano e alveolar inferior estão relacionados com a remoção óssea nas áreas do mento e ramo mandibular respectivamente. Além disso, trismo, hemorragia, deiscência e fratura mandibular podem ser consequência desta última região, enquanto desvitalização dos dentes anteriores pode ocorrer durante a remoção de um bloco ósseo removido da região do mento (LI; WANG, 2008; CORREIA et al., 2012).

Quando a área receptora necessita de maior quantidade de enxerto, é sugerido que o mesmo seja colhido das áreas anterior ou posterior da crista ilíaca, diante da simplicidade de técnica. A região posterior oferece maior volume ósseo comparado à região anterior, além de menor morbidade (THORWARTH et al., 2005; CANULLO; DELLAVIA, 2009; CORREIA et al., 2012). Menores volumes podem ser colhidos do mento, porém, em relação às áreas doadoras, o enxerto removido da calvária para o procedimento de levantamento de seio maxilar é considerado o mais previsível (MISCH, 1987; BLOCK; KENT, 1997). Blocos removidos do mento têm sido defendidos para ambos os enxertos de seio e onlay, pois são ossos de origem membranosa e, presumivelmente, menos propensos à reabsorção do que o osso da crista ilíaca (HIRSCH; ERICSSON, 1991). Biópsia de um paciente, 25 meses após enxerto removido da região do mento, demonstrou $40,5 \%$ de tecido mole e $59,4 \%$ de tecido ósseo (MOY; LUNDGREN; HOMES, 1993).

Vários trabalhos descrevem a utilização do osso da crista ilíaca e, ao comparar com o osso da área do túber da maxila, não foram encontradas diferenças clínicas qualitativas relacionadas à osseointegração e à manutenção do enxerto (WHITTAKER et al., 1989; KENT; BLOCK, 1989; JENSEN; SINDET-PEDERSEN, 1991; BLOCK; KENT, 1993; JENSEN; SINDET-PEDERSEN; OLIVER, 1994; BLOCK; KENT, 1997). Porém, infelizmente, a maioria dos estudos são de curto prazo, o que torna difícil a confiança dessa comparação (BLOCK; KENT, 1997). Quando implantes foram instalados em osso enxertado oriundo da crista ilíaca, maior porcentagem de osso em contato com a superfície do implante (30-36\%) foi encontrada, após 26 semanas, comparada ao grupo controle (não enxertado) (20-25\%) (HAAS et al., 1998a; HASS et al., 1998b) e, após 12 semanas do procedimento de levantamento de seio maxilar, um aumento de $47 \%$ de neoformação óssea foi constatado (JAKSE et al., 2003; BROWAEYS; BOUVRY; DE BRUYN, 2007). 
Dependendo da área doadora, a qualidade do tecido ósseo é diferente. O osso esponjoso pode ser removido de qualquer região contendo espaço medular (mento, tíbia, região retromolar e túber da maxila). Ele possui algumas vantagens como a rápida revascularização e produção inicial de tecido ósseo, porém não é o ideal para a estabilização do implante quando instalado em soalho do seio maxilar muito fino. O osso córtico-medular, em bloco, é facilmente mantido com parafusos e os implantes se estabilizam com mais facilidade, entretanto sua revascularização é lenta, o que o torna mais susceptível à infecção (BLOCK; KENT, 1997). Quando utilizado como enxerto do tipo onlay, ocorre reabsorção do osso esponjoso resultando numa redução do aumento ósseo esperado. Enxertos em bloco córtico-medulares apresentam a vantagem de serem resistentes e ao mesmo tempo passíveis de se acomodar no local que necessita de preenchimento, além de serem capazes de manter maior volume ósseo comparado aos enxertos esponjosos utilizados como onlay (BLOCK; KENT, 1997).

Ainda existe uma grande imprevisibilidade do grau de reabsorção do enxerto ósseo autógeno. Autores acreditam que a média é em torno de 5 a 20\% (JENSEN; SINDETPEDERSEN, 1991; JENSEN; SINDET-PEDERSEN; OLIVER, 1994; VERHOEVEN et al., 2000; GEURS et al., 2001; RAGHOEBAR et al., 2001). Na ausência de carga funcional obtida na presença do implante, foi observada uma redução de $40 \%$ em volume ósseo mensurado (SCHLEGEL et al., 2003). Quando o osso autógeno foi associado com a proteína morfogenética tipo 7 (BMP-7), hidroxiapatita ou osso bovino mineralizado, maior formação óssea foi encontrada (HÜRZELER et al., 1997; HASS et al., 1998a; HASS et al., 1998b; ROLDÀN et al., 2004; BROWAEYS; BOUVRY; DE BRUYN, 2007).

Estudo longitudinal de 5 anos, em 100 pacientes submetidos à cirurgia de levantamento de seio maxilar e enxerto do tipo onlay, comparou a taxa de sobrevivência dos implantes e as respectivas taxas de reabsorção dos enxertos ósseos autógeno oriundos da crista ilíaca anterior e da crista ilíaca posterior. A taxa de sobrevivência total dos implantes foi 93,1\% (526 de 565) (WILTFANG et al., 2005). No grupo de pacientes submetidos a cirurgia de levantamento de seio maxilar, de 349 implantes 330 foram bem sucedidos (94,6\% de taxa de sobrevivência), sendo estatisticamente significante em relação ao outro grupo. Quando a área doadora foi a crista ilíaca anterior, foi obtida uma taxa de sucesso de 92,4\% (159 de 172 implantes) e na crista ilíaca posterior de 93,9\% (369 de 393), não apresentando diferenças estatisticamente significantes entre os 2 grupos de pacientes. Ainda, nenhum implante foi perdido depois dos 3 primeiros anos (WILTFANG et al., 2005). Radiografias panorâmicas demonstraram grau de reabsorção óssea no primeiro ano, equivalente a $17 \%$, no segundo e 
terceiro anos $7 \%$ e $3 \%$ respectivamente. A partir do terceiro ano, não houve alteração considerada estatisticamente significante, independente da área doadora (WILTFANG et al., 2005). Entretanto outros autores concluíram que, dependendo da região doadora do enxerto ósseo autógeno, existe uma diferença na mineralização, sendo descritas: retromolar: $68,7 \% \pm 8,75 \%$; crista ilíaca anterior: $35,1 \% \pm 7,6 \%$; crista ilíaca posterior: $30,7 \% \pm 9,5 \%$ (THORWARTH et al, 2005). Em relação à reabsorção, foram encontrados os valores: região retromolar $(53,0 \% \pm 5,15 \%)$, considerado um significativo decréscimo; na crista ilíaca anterior uma estável mineralização $(36,1 \% \pm 7,59 \%)$ e crista ilíaca posterior um ligeiro aumento $34,5 \% \pm 6,5 \%$ (THORWARTH et al, 2005).

Por possuir todas as propriedades ideais descritas anteriormente, o osso autógeno é considerado o padrão-ouro, quando comparado aos outros substitutos ósseos, é extremamente confiável e livre de antigenicidade por ser oriundo do próprio paciente. (YILDIRIM et al., 2000; GREENWALD et al., 2001; APELT et al., 2004; GIANNOUDIS; DINOPOULOS; TSIRIDIS, 2005; TAMIMI et al., 2006; ARAUJO-PIRES, 2010) A grande desvantagem da aplicação desse tipo de enxerto é a morbidade da área doadora, considerada maior do que na área receptora. Além disso, uma cirurgia adicional aumenta o tempo cirúrgico e, consequentemente, o sangramento, edema e risco de complicações como infecção, parestesia e dor pós-operatória são maiores (MARX; SAUNDERS, 1986; KURZ; GARFIN; BOOTH, 1989; MARX, 1992; BLOCK; KENT, 1997; MOORE; GRAVES; BAIN, 2001; LAURECIN; KHAN; EL-AMIN, 2006). Uma outra limitação é que nem sempre pode ser utilizado o volume ósseo requerido. Em muitos casos, o volume disponível para a doação é limitado, gerando outro problema (LAURECIN; KHAN; EL-AMIN, 2006). Dor persistente por mais de 3 meses foi relatada em até $15 \%$ dos pacientes que realizaram enxerto ósseo autógeno colhido da crista ilíaca. A quantidade de dor parece ser proporcional à extensão de dissecção requerida para a remoção do enxerto (FERNYHOUGH; SCHIMANDLE; WEIGEL, 1992).

\subsubsection{Enxerto ósseo alógeno}

O enxerto ósseo alógeno ou aloenxerto, cujo adjetivo é alogênico ou alógeno, é transferido entre dois indivíduos geneticamente diferentes da mesma espécie (STEVENSON, 1999; MUSCHLER; LANE, 1992). Atualmente, não se utilizam células vivas oriundas de outro doador nos enxertos. Portanto, os implantes alógenos são biomateriais com base alógena e serão explorados no item substitutos ósseos (MUSCHLER; LANE, 1992). 
Situação especial existe quando o tecido doador é implantado em um irmão gêmeo idêntico (monozigótico), denominado isoenxerto, cujo adjetivo é isogênico ou isógeno (STEVENSON, 1999).

\subsubsection{Enxerto ósseo xenógeno}

O enxerto heterólogo, cujo adjetivo é xenogênico ou xenógeno, é transplantado entre espécies diferentes, ou seja, o tecido ósseo doador é oriundo de uma espécie diferente da que receberá o enxerto, principalmente, entre a origem animal (STEVENSON, 1999; MUSCHLER; LANE, 1992). Em 1682, foi relatado um caso de enxerto xenógeno removido da calvária de um cão para reparar o crânio de um soldado russo. Porém, por razões religiosas, o enxerto foi removido dois anos depois (MULLIKEN; GLOWACKI, 1980; DUPOIRIEUX; POURQUIER; SOUYRIS, 1995). Assim como o enxerto alógeno, este enxerto não é aplicado na prática dos enxertos, pois não são utilizadas células vivas oriundas de outro doador animal. Entretanto os implantes xenógenos são substitutos ósseos rotineiramente utilizados, especialmente, em cirurgias de levantamento de seio maxilar (MUSCHLER; LANE, 1992).

\subsubsection{Substitutos Ósseos - Classificação}

Diante das limitações, desvantagens e morbidades associadas à utilização do osso autógeno em cirurgias de levantamento de seio maxilar, foram introduzidos substitutos ósseos como uma solução alternativa, utilizando-se dois critérios básicos para o sucesso clínico: osteocondução e/ou osteoindução. As grandes vantagens são: facilidade em esterilizar, armazenar, manusear e adquirir o substituto ósseo baseado nas preferências e necessidades de cada caso (BARONE et al., 2005; PIKDÖKEN et al., 2011; CORREIA et al., 2012). Muitos dos produtos já estão disponíveis para uso clínico há tempos e outros, ainda, em desenvolvimento. Podem ter origem animal ou ser totalmente sintéticos. Os substitutos ósseos de origem animal podem ser derivados xenogênicos e alogênicos (LAURECIN; KHAN; ELAMIN, 2006; MIYAZAKI et al., 2009) e aqueles totalmente sintéticos, também denominados aloplásticos, podem ser divididos em: polímeros, cerâmicas, metálicos e compósitos. Mais recentemente pesquisados, existem ainda os fatores de crescimento e celulares (LAURECIN; KHAN; EL-AMIN, 2006; MIYAZAKI et al., 2009). 
Neste capítulo, a descrição dos substitutos ósseos existentes baseou-se na classificação proposta por alguns autores (LAURECIN; KHAN; EL-AMIN, 2006), a qual leva em consideração sua composição principal, já que podem apresentar associações de mais de um material.

\subsubsection{Substitutos ósseos originados de osso alógeno ou implante ósseo alógeno}

O implante ósseo alógeno é um substituto ósseo bastante utilizado em cirurgias reconstrutivas e pode ser utilizado isoladamente ou em associação com outros biomateriais. É uma alternativa que oferece bastante semelhança ao osso autógeno, exceto pela preservação de células osteogênicas deste último. Além disso, apresentam propriedades osteocondutoras e podem apresentar atividade osteoindutoras (SOMANATHAN; SIMUNEK, 2006; LAURECIN; KHAN; EL-AMIN, 2006; ESPOSITO et al., 2009; ESPOSITO et al., 2010; CORREIA et al., 2012). Ele é originado de cadáveres doadores, colhido e tratado por diversas técnicas, preservando a sua propriedade osteocondutora (liofilização, irradiação e esterilização) e fornecido por bancos de ossos licenciados. Sua principal vantagem, comparado ao osso autógeno, é a eliminação de um segundo sítio cirúrgico, reduzindo a morbidade ao paciente (GREENWALD et al., 2001; LAURECIN; KHAN; EL-AMIN, 2006). Além disso, na presença de grandes defeitos ósseos, eles podem ser disponíveis em grandes volumes e são capazes de fornecer apoio estrutural (MOORE; GRAVES; BAIN, 2001). Entretanto apresentam algumas limitações, como a inexistência de muitos bancos de ossos, pelo alto custo de manutenção e controle rigoroso para impedir a transmissão de doenças, além de apresentar aspectos negativos como o risco de infecção. Ainda, não existem estudos avaliando seu comportamento a longo prazo (MOORE; GRAVES; BAIN, 2001).

Os implantes alógenos são reconhecidos como enxerto liofilizado desmineralizado humano (DFDBA) ou matriz óssea desmineralizada (DBM). A DBM é capaz de melhorar a regeneração óssea pela sua capacidade osteocondutiva. Muitas vezes podem ser associados com biomateriais aloplásticos ou implantes xenógenos para suprir algumas deficiências de propriedades (SCHWARTZ et al., 2007). Autores demonstraram que a quantidade de osso formado depende da forma como é utilizado o DFDBA (SCHWARTZ et al., 2007).

Apesar de os implantes alógenos serem tratados por diversos métodos eleitos seguros, por exemplo: congelamento, irradiação gama e o óxido de etileno, o risco de transmissão de doenças a partir do doador para o receptor não é completamente removido (LAURECIN; KHAN; EL-AMIN, 2006). O risco de infecção bacteriana é maior conforme aumenta o 
tamanho do enxerto e pode ser visto em mais de $10 \%$ dos casos. Transmissão viral é um risco potencial, especialmente em relação ao vírus da Hepatite B, C e HIV que, apesar de ser incomum, já foi documentado oriundo de cadáveres doadores (CONRAD et al., 1995; TOMFORD, 1995; CDC, 1988; ARAUJO-PIRES, 2010). Autores estimam que o risco de transmissão do vírus da imunodeficiência humana (HIV) somente com implante alógeno é um em 1,6 milhões casos (BOYCE; EDWARDS; SCARBOROUGH, 1999). Um caso de transmissão da hepatite $\mathrm{B}$ e 3 casos de transmissão da hepatite $\mathrm{C}$ foram relatados com a sua utilização (CONRAD, et al., 1995; TOMFORD, 1995; ARAUJO-PIRES, 2010). Outros casos mais recentes de infecção foram relatados, sendo que um deles causou morte num paciente após infecção por Clostridium sordellii, oriunda de implante alógeno em cirurgia reconstrutiva no joelho (CDC, 2002; LAURECIN; KHAN; EL-AMIN, 2006; ARAUJOPIRES, 2010). Outros 25 casos de infecção foram relacionados com esse tipo de implante (CDC, 2002; LAURECIN; KHAN; EL-AMIN, 2006). Vale ressaltar que, embora muitos métodos de tratamento sejam capazes de reduzir o risco de transmissão de doenças, aqueles que esterilizam o tecido acabam eliminando proteínas e outros fatores responsáveis pela osteoindutividade do tecido.

Complicações associadas ao implante alógeno incluem fraturas, ausência de osseointegração e infecção (MANKIN; GEBHARDT, 1996). Taxas de fratura de até 19\% foram relatadas (MOORE; GRAVES; BAIN, 2001). A osseointegração do implante alógeno é difícil de ser avaliada. Foram encontradas algumas discrepâncias entre os achados clínicos, radiológicos e microscópicos. Aspectos radiográficos da ausência de osseointegração desse tipo de substituto ósseo pode ser esperado em até 17\% dos casos (MOORE; GRAVES; BAIN, 2001).

Alguns exemplos de implantes alógenos comercializados são: Allogro® (AlloSource, Centennial, Colo), Opteform ${ }^{\circledR}$ (Exactech, Inc, Gainesville, Fla), Grafton® (BioHorizons, Birmingham, Ala), OrthoBlast ${ }^{\circledR}$ (IsoTis OrthoBiologics, Irvine, Calif) (LAURECIN; KHAN; EL-AMIN, 2006).

2.2.3.2 Substitutos ósseos originados de osso xenógeno ou implante ósseo xenógeno

Os substitutos ósseos cujo principal componente é derivado do osso xenógeno é denominado implante ósseo xenógeno. O implante ósseo xenógeno mais comumente utilizado é de origem bovina, após os componentes orgânicos serem quimicamente tratados, restando 
sua estrutura mineral. Origem equina e porcina também não são incomuns (CORREIA et al., 2012). Outra origem é de exoesqueleto de coral (CORNELINI et al., 2004; ARAUJO-PIRES, 2010). Os substitutos ósseos de origem xenogênica têm demonstrado excelente propriedade osteocondutora (HALLMAN; NORDIN, 2002; SCHLEGEL et al., 2003; VALENTINI; ABENSUR, 2003; JONH; WENZ, 2004) e alguns estudos sugerem pequenas propriedades osteoindutivas (SOMANATHAN; SIMUNEK, 2006; ESPOSITO et al., 2009; ESPOSITO et al., 2010; CORREIA et al., 2012). Bio-Oss® (Geistlisch Farmacêutica, Wolhusen, Suíça) é um substituto ósseo para enxerto, derivado de osso medular bovino desproteinizado, com a estrutura da hidroxiapatita do tecido ósseo altamente porosa, semelhante ao osso cortical da espécie humana. Os componentes orgânicos são removidos quimicamente ou por calor, restando um esqueleto de suporte para as células osteogênicas. Possui propriedades osteocondutora e antigênica. Na literatura, encontram-se muitos estudos e citações a respeito desse substituto ósseo, que é utilizado na sua forma particulada para o preenchimento de defeitos ósseos (DIÈS et al. 1996; SKOGLUND; HISING; YOUNG, 1997; HÜRZELER et al., 1997; VALENTINI et al., 1998; ZITIZMANN; SCHARER, 1998; YILDIRIM et al., 2000; ARAÚJO; LILJENBERG; LINDHE, 2010; ARAÚJO-PIRES, 2010). Além disso, ele funciona como um arcabouço para a deposição do novo osso (DIÈS et al. 1996; SKOGLUND; HISING; YOUNG, 1997; ZITIZMANN; SCHARER, 1998; ARAÚJO et al., 2001). Em relação à degradação, trabalhos demonstraram ser lenta ou serem não degradáveis completamente (ARAUJO et al., 2002; SBORDONE et al., 2009; HALLMAN; NORDIN, 2002; BERGLUNDH; LINDHE, 1997). Estudos relataram um tempo de reabsorção entre 3 a 4 anos (DIÈS et al., 1996; SKOGLUND; HISING; YOUNG, 1997; VALENTINI et al., 1998; ZITIZMANN; SCHARER, 1998).

Diversos estudos em animais e humanos têm demonstrado que este material é promissor em comparação com outros substitutos ósseos (HAAS; DONATH; FÖDINGER, 1998; BERGLUNDH; LINDHE, 1997), pois em cirurgias de levantamento de seio maxilar têm demonstrado bons resultados clínicos. Autores relatam uma eficácia de 80 a $100 \%$ relacionada ao Bio-Oss® (Geistlisch Farmacêutica, Wolhusen, Suíça), sugerindo ser tão efetivo quanto o enxerto ósseo autógeno (ESPOSITO et al., 2009).

Um estudo propôs a utilização pura de osso bovino mineralizado como enxerto, e a análise histológica evidenciou a substituição do mesmo por osso vital, evidência de aumento da densidade radiográfica e estabilidade do enxerto até 1,5 anos depois, na ausência de implantes dentários (MCALLISTER et al., 1999). O uso de osso de origem bovina em procedimentos de levantamento de seio maxilar também foi investigado em outros trabalhos 
(WETZEL; STICH; CAFFESSE, 1995; HASS et al., 1998a; HASS et al., 1998b; MARGOLIN et al., 1998; TERHEYDEN et al., 1999; FURST et al., 200e; SCHLEGEL et al., 2003; FUERST et al., 2004; ROLDÀN et al., 2004).

Avaliação de implantes dentários instalados na região de levantamento de seio maxilar, utilizando osso bovino mineralizado, apresentou $63 \%$ de neoformação óssea em contato com a superfície do implante (SCHLEGEL et al., 2003), 27\% (WETZEL; STICH; CAFFESSE, 1995), e 38\% (TERHEYDEN et al., 1999) após 6 meses de proservação. Utilizando somente o osso bovino mineralizado, $23 \%$ do osso recém-formado foi observado em 12 semanas (FUERST et al., 2004), portanto, ele mostrou ser lentamente reabsorvido e parece se comportar como um enxerto semipermanente (SCHLEGEL et al., 2003). Uma redução de volume de $16 \%$ em menos de 180 dias foi relatada em beagles e a microscopia revelou inflamação crônica nas áreas marginais (HASS et al., 1998a). Além disso, nenhuma das amostras apresentou neoformação óssea ao redor do enxerto, além das superfícies de contato (HASS et al., 1998a).

Estudo clínico randomizado avaliou, em 10 pacientes, duas formas diferentes de tratamento em cada seio maxilar: uma membrana rígida reabsorvível em um seio maxilar e, no outro, 100\% de Bio-Oss® (Geistlisch Farmacêutica, Wolhusen, Suíça). Os resultados, após 6 meses, demonstraram um aumento ósseo estatisticamente significante entre os grupos e, histologicamente, mais osso foi formado do lado do grupo Bio-Oss® (Geistlisch Farmacêutica, Wolhusen, Suíça) $(36,1 \%)$ comparado ao da membrana $(24,2 \%)$. (FELICE et al., 2009). Outros autores reavaliaram os pacientes deste mesmo estudo, após um ano, os quais não demonstraram diferença estatisticamente significante de perda óssea nos 2 grupos (em média de 1,5mm no grupo membrana e 1,7mm no grupo Bio-Oss®) (ESPOSITO et al., 2010). Além disso, diferenças estatísticas significantes não foram apresentadas no insucesso dos implantes, próteses e complicações peri-implantares entre os 2 grupos (ESPOSITO et al., 2010).

Outras espécies utilizadas como substituto ósseo são os corais marinhos das famílias Poritidae e Goniopora. Eles sofrem reações hidrotérmicas com o fosfato de amônio bifásico e são convertidos em hidroxiapatita (ANDRADE, 2004). O uso da hidroxiapatita porosa, como um substituto ósseo em seios maxilares, foi apresentado em alguns estudos com o mesmo modelo experimental, associado ou não ao osso autógeno (HÜRZELER et al., 1997; QUINONES et al., 1997). Eles apresentaram resultados microscópicos qualitativos e quantitativos semelhantes de quantidade significativa de neoformação óssea. As partículas de hidroxiapatita porosa mostraram-se integradas com o osso recém-formado. A instalação de 
implantes simultaneamente ao levantamento de seio maxilar resultou em menor quantidade de tecido ósseo mineralizado na interface com o implante quando comparado aos implantes instalados em outra fase cirúrgica (QUINONES et al., 1997). Os autores concluíram que a presença de carga com o implante gera um efeito positivo sobre a porcentagem de neoformação óssea na interface com o implante. Além disso, implantes recobertos por hidroxiapatita podem beneficiar ainda mais o tratamento (QUINONES et al., 1997). Em outro estudo, não houve diferença significante de neoformação óssea na superfície do implante entre o osso autógeno e a hidroxiapatita porosa, apesar de ambos mostrarem maior do que grupo controle, o qual não usou qualquer biomaterial (HASS et al., 2002).

A hidroxiapatita de origem natural apresenta limitações, como baixa resistência mecânica e ausência de padronização, variando seu formato, tamanho e quantidade (ANDRADE, 2004). A hidroxiapatita sintética pode ser obtida facilmente pela reação entre reagentes inorgânicos, preparada por diferentes métodos e com bons resultados. Alguns exemplos de sua utilização estão comentados no próximo item.

\subsubsection{Substitutos ósseos compostos de cerâmica}

Os substitutos ósseos constituídos de cerâmica são bastante utilizados tanto representando o biomaterial principal como associados a outros. Quimicamente, as biocerâmicas podem ser classificadas em: monolítica (somente uma composição química); compósitos (dois ou mais constituintes químicos diferentes). Podem ser de alta ou baixa densidade e, de acordo com seu comportamento biológico, podem ser bioinertes, quando são toleradas pelo organismo, apresentando estabilidade, durabilidade e ausência de reatividade química ou biológica (exemplos: zircônia e alumina); bioativas: promovendo uma ligação forte e estável na interface tecido ósseo-implante (hidroxiapatitas e biovidros) e absorvíveis, quando após certo período em contato com o tecido ósseo são fagocitadas ou degradadas pelo organismo e, finalmente, substituídas pelos tecidos adjacentes. Esta última classe tem demonstrado ser promissora na área médica para a reconstituição dos tecidos ósseos (OLIVEIRA, 2010).

As biocerâmicas que mais se destacam com essa finalidade são: fosfato de cálcio [fosfato tricálcio alfa $(\alpha)$ e beta $(\beta)$ ], sulfato de cálcio, cerâmica bioativa e vidro bioativo. A utilização das biocerâmicas, principalmente o fosfato de cálcio, deve-se ao fato de que o componente inorgânico principal do osso é a hidroxiapatita (HA), a qual faz parte de um subgrupo dos fosfatos de cálcio (TAY; PATEL; BRADFORD, 1999; LAURENCIN; KHAN; 
EL-AMIN, 2006; ARAUJO-PIRES, 2010). Diante da semelhança química entre a HA sintética e o osso humano, ela tem sido um dos principais substitutos ósseos pesquisado destinado ao implante ósseo, pois atua como um suporte para a regeneração dos tecidos (ANDRADE, 2004).

Embora existam muitos tipos de fosfato de cálcio $(\mathrm{CaP})$ obtidos por diferentes métodos e técnica de síntese, os principais pesquisados atualmente são o fosfato tricálcio (TCP) e a hidroxiapatita (HA). Os compostos a base $\mathrm{CaP}$ apresentam excelente biocompatibilidade (OSBORN; NEWESELY, 1980; KOHRI et al., 1993; SHARPE; SAMMONS; MARQUIS, 1997; ARAUJO-PIRES, 2010), atividade ostecondutora e são biodegradáveis (LEGEROS, 2008). A HA é um composto inorgânico muito semelhante à estrutura da fase mineral do osso, porém apresenta fragilidade e degradação lenta (de 1 a $2 \%$ ao ano) (MOORE; GRAVES; BAIN, 2001). Entretanto o TCP apresenta uma taxa de biodegradação muito rápida (ELLINGER; NERY; LYNCH, 1986), nem sempre concomitante com a deposição óssea (BUSER et al., 1998). Estudos atuais com o TCP de baixa temperatura demonstraram que esse material acelera a regeneração óssea (ARAÚJO et al., 2010; ARAÚJO; LILJENBERG; LINDHE, 2010; ARAUJO-PIRES, 2010).

O TCP- $\beta$ e $\alpha$ tem sido estudado, recentemente, devido sua composição ser muito semelhante à estrutura óssea humana. Ele apresenta uma capacidade de adsorção e dissolução pelo meio biológico muito maior do que a HA (BELLINI 2007; HENCH 1998). Existem 3 formas diferentes de TCP: forma alotrópica estável (TCP- $\beta$ a baixas temperaturas); fase estável (TCP- $\alpha$ : a temperatura é acima de 1180 a 1430) e, acima desta temperatura: fase super (TCP- $\alpha$ '). O TCP- $\beta$ é o mais explorado atualmente pelas suas características de biocompatibilidade, bioatividade e similaridade química com a matriz óssea dos tecidos duros (OLIVEIRA, 2010).

Os politipos de HA também variam conforme sua composição e síntese. Ela tem sido produzida desde a década de 70 e utilizada desde 80 como material de preenchimento, pois apresenta estrutura cristalográfica similar à fase mineral dos ossos (LEGEROS, 2002). A HA estequiométrica é considerada promissora, pois favorece a regeneração óssea. Além disso, tem facilidade de substituições catiônicas e aniônicas, facilitando a incorporação de íons à sua estrutura (LEGEROS, 1991).

Autores avaliaram grânulos de HA nanocristalina em seios maxilares de 16 pacientes e, 24 semanas após, a regeneracão óssea foi de $48 \%$ do volume enxertado (CANULLO; DELLAVIA, 2009). Os autores demonstraram resultados clínicos satisfatórios na osseointegração dos implantes dentários desses pacientes, devido à maturação precoce do 
osso regenerado, verificando rápida redução das partículas do biomaterial. Achados similares foram encontrados em outro estudo (GÖTZ et al., 2008).

As cerâmicas bifásicas compostas por CaP bifásico (HA+TCP- $\beta$ ) estão sendo desenvolvidas a fim de melhorar o controle de dissolução de íons Ca e $\mathrm{P}$ quando destinada à regeneração óssea (LEGEROS, 1991, DALCUSI et al., 1989). O BoneCeramic $®$ (Straumann®, Basel, Suíça) é um biomaterial completamente sintético, com propriedade osteocondutora e propriedades de reabsorção que favorecem a formação de osso vital (BOIX et al., 2004; DE COSTER et al., 2011). É composto por CaP bifásico (BCP), uma combinação de HA $(60 \%$ em peso e $40 \%$ em peso de TCP- $\beta$ ). Estudos em defeitos peri-implantares demonstraram estímulo de regeneração óssea ao redor de implantes dentários que tenham sido colocados em alvéolos, imediatamente após a extração dentária. Avaliação microscópica e radiográfica demonstrou osso regenerado com características similares às do osso localizado em áreas não defeituosas (SALGADO et al., 2007). Entretanto poucos estudos foram feitos em seres humanos e animais utilizando esse material. Um estudo recente utilizou o BoneCeramic ${ }^{\circledR}$ (Straumann®, Basel, Suíça) como material para enxerto após a extração dentária em humanos, e resultou em atraso no processo de reparo alveolar, sendo sugerido novos estudos com o mesmo (DE COSTER et al., 2009).

O Sulfato de cálcio, conhecido como gesso Paris, é utilizado desde o século XIX (TAY; PATEL; BRADFORD, 1999; ARAUJO-PIRES, 2010). Apresenta características semelhantes ao $\mathrm{CaP}$, sendo inerte e biodegradável. Sua principal propriedade é a osteocondução, ou seja, seu arcabouço possibilita a neoformação óssea pelos osteoblastos preexistentes (LAURECIN; KHAN; EL-AMIN, 2006).

Autores classificam, dentre os materiais cerâmicos totalmente sintéticos, os vidros e cerâmicas bioativas como os mais promissores por serem inertes, biocompatíves e apresentarem propriedades osteocondutivas (STRNAD, 1992; FURUSAWA; MIZUNUMA, 1997; GROSS; BRANDES, 1981; SHIMIZU et al., 1997; LAI; GARINO; DUCHEYNE, 2002). O termo bioatividade se refere à habilidade que certas composições de vidros apresentam em se ligarem ao tecido ósseo circundante ao implante, induzindo a formação de uma camada de HA em sua superfície. Isso ocorre quando o vidro bioativo entra em contato com os fluidos tissulares, desencadeando reações que resultam na formação de hidroxicarbonatoapatita. Atualmente, outros materiais cerâmicos como a HA sintética, o fosfato tricálcio sinterizado e algumas vitro-cerâmicas também podem ser bioativos sob certas condições de síntese (HENCH, 1998; KOKUBO, 1991; ANDRADE; DOMINGUES, 2006). Para um melhor desempenho ao se ligar ao tecido ósseo, esses materiais possuem $45 \%$ de 
dióxido de silício ( $\mathrm{SiO} 2), 24,5 \%$ de óxido de cálcio $(\mathrm{CaO}), 24,5 \%$ de óxido de sódio $(\mathrm{Na} 2 \mathrm{O})$ e $6 \%$ de pentóxido de difósforo (P2O5) por peso. Apresentam como vantagens forte união com o tecido ósseo, módulo de elasticidade similar ao osso e evita a encapsulação fibrótica na interface do material quando implantado (SCHEPERS; PINRUETHAI, 1993).

Exemplos de vidro bioativo disponível comercialmente são: Biogran® (Orthovita e 3i, Implant Innovations, Inc, Palm Beach Gardens, Fla) e Perioglass ${ }^{\circledR}$ (NovaBone Products, LLC, Alachua, Fla) (LAURECIN; KHAN; EL-AMIN, 2006). Os substitutos ósseos compostos por vidros bioativos são reforçados por óxidos (óxido de sódio, óxido de cálcio, pentóxido de fósforo e dióxido de silício) e permitem uma osseointegração com o tecido ósseo, embora não apresentem boa resistência mecânica, limitando sua aplicação em locais onde receberão força de compressão (DAMIEN; PARSONS, 1991). Em relação a sua bioatividade, foram descritos os seguintes mecanismos: processo de difusão iônica do vidro; transformação no interior em um gel hidratado; contradifusão da matriz extracelular em direção à superfície do vidro e precipitação de fosfato de cálcio no vidro (GATTI et al., 2006; CRUZ et al., 2006).

Vários estudos analisaram a eficácia dos substitutos ósseos compostos de vidro bioativo e demonstraram suas propriedades bioativas e osteocondutivas (FETNER; HARTIGAN; LOW, 1994; JOHNSON et al., 1997; SCHMIT et al., 1997; TURUNEN et al., 1997; WHEELER et al., 1997; CANCIAN, 1998; WHEELER et al., 1998; AL RUHAIMI, 2001; HALL et al., 1999; VOGEL et al., 2001; CHAN et al., 2002; BOSETTI; CANNAS, 2005; SCHEPERS et al., 1991, SCHEPERS; BARBIER; DUCHEYNE, 1998). Na literatura é encontrada muita divergência de resultados quando estes são comparados. Isso se deve às diferentes técnicas de síntese utilizadas para obtenção dos mesmos, pois o grau de pureza, formato do grânulo e o nível de entrelaçamento dos cristais afetam a capacidade de dissolução dos grânulos e a resposta tecidual (DALCUSI; LEGEROS; MITRE, 1998; FULMER et al., 2002). Quando utilizado em levantamento de seio maxilar de 25 pacientes, Biogran® (Orthovita e 3i, Implant Innovations, Inc, Palm Beach Gardens, Fla) demonstrou crescimento ósseo, comprovando suas propriedades osteocondutivas (FURUSAWA; MIZUNUMA, 1997; COSSO; MANDIA; LENHARO, 2000; CRUZ et al., 2006). Estudo demonstrou alto poder osteocondutivo, após levantamento de seio maxilar, utilizando o vidro bioativo hidratado com soro fisiológico e, posteriormente instalação de implantes, sugerindo seu uso isolado ou associado ao osso autógeno (COSSO; MANDIA; LENHARO, 2000). Outros estudos clínicos e animais também indicaram o uso desse substituto ósseo como em procedimentos de levantamento de seio maxilar (CARDIOLI et al., 2001; TADJOEDIN et al., 2002). 
Entretanto autores (COSSO; MANDIA; LENHARO, 2000) demonstraram formação óssea num ritmo mais lento quando usado isoladamente. As principais vantagens oferecidas pelo vidro bioativo é ser absorvível, apresentar ausência de riscos de transmissão de doenças ou respostas imunológicas e auxiliar na hemostasia (GATTI et al., 2005). As cerâmicas bioativas apresentam propriedades mecânicas melhoradas em relação aos vidros bioativos, porém ainda são frágeis o bastante para fraturar quando submetidas a uma carga cíclica (ARAUJO-PIRES, 2010; GIANNOUDIS; DINOPOULOS, TSIRIDIS, 2005). No intuito de melhorar sua resistência à fratura, métodos de incorporação de fibras de aço inoxidável e zircônia têm sido realizados (CAO; HENCH, 1996).

O uso de Cerabone ${ }^{\circledR}$ (Botiss dental $\mathrm{GmbH}$, Berlim, Alemanha) é referido, em revisão sistemática, como sendo tão efetivo quanto o uso do osso autógeno em maxilares atróficos (ESPOSITO et al., 2010). NanoBone® (Artoss GmbH, Rostock-Warnemünde, Alemanha) também foi avaliado como substituto ósseo e autores concluíram que a sua utilização é confiável, mesmo em situações anatómicas desfavoráveis (CANULLO; DELLAVIA, 2009). Além disso, NanoBone ${ }^{\circledR}$ (Artoss GmbH, Rostock-Warnemünde, Alemanha) demonstrou ser reabsorvido e parcialmente substituído por novo osso regenerado (CANULLO; DELLAVIA, 2009). Outros exemplos de substitutos ósseos à base de cerâmica são: Norian SRS® (Synthes, Inc, West Chester, Pa), ProOsteon ${ }^{\circledR}$ (Interpore Cross International, Irvine, Calif), Osteoset ${ }^{\circledR}$ (Wright Medical Technology, Inc, Arlington, Tenn) (LAURECIN; KHAN; EL-AMIN, 2006).

\subsubsection{Substitutos ósseos poliméricos}

Os compostos polímeros são macromoléculas que se unem através de uma reação de polimerização dos seus monômeros. Podem ter origem natural (látex natural, seda, celulose) ou sintética (Poli cloreto de vinila (PVC); policloropreno; poliestireno; nylon; teflon; poliésteres; polietileno; borracha butilada; silicones; resinas; polipropileno; policarbonato; resinas; elastômeros; poliamidas). A utilização de polímeros biodegradáveis como arcabouço (scaffolds) para cultura de células tem se destacado como uma alternativa na terapia regenerativa óssea. Vários polímeros naturais e sintéticos estão sendo estudados e os polímeros biodegradáveis são considerados como os melhores candidatos para a construção de scaffolds destinados à reparação tecidual (GIRONES MOLERA; MENDEZ; SAN ROMAN, 2012). Dentre eles, o ácido poliláctico (PLA), poliglicólico ácido (PGA) de policaprolactona (PCL) e seus copolímeros são já amplamente utilizados na fabricação de scaffolds (LIU; MA, 2004; REZWAN; CHEN; BLAKER, 2006; BOSCHETT et al., 2008; 
PUPPI et al., 2010; GIRONES MOLERA; MENDEZ; SAN ROMAN, 2012). Além de poliésteres alifáticos sintéticos, diversos outros polímeros sintéticos biodegradáveis (polifosfazenos, policarbonatos ou polianidridos) e polímeros naturais tais como o colágeno (KEOGH; O' BRIEN; DALY, 2010) quitosana (PUPPI et al., 2010; MUZZARELLI, 2011), elastina (ANNABI et al., 2009; WISE; MITHIEUX; WEISS, 2009) e ácido hialurônico (PATTERSON et al., 2010) têm sido propostos com a mesma finalidade. Devido à composição química, poliuretanos segmentados podem ser facilmente adaptados como bioestáveis ou biodegradáveis e rígidos ou elásticos, dependendo da aplicação desejada. Os poliuretanos elastoméricos biodegradáveis têm sido considerado excelentes candidatos para a síntese de scaffolds para ser aplicado como substitutos ósseos (BIL et al., 2007; GUELCHER et al., 2008; LASCHKE, et al., 2009; ZAWADZAK et al., 2009). Quando CaP ou HA são incorporadas a estes scaffolds biopoliméricos, ocorre maior formação óssea. A adição de TCP- $\alpha$ provou aumentar as propriedades de osteocondução dos scaffolds in vivo (VERTENTEN et al., 2008). As células mesenquimais cultivadas sobre este material têm demonstrado propriedades fenotípicas osteoblásticas (DAWSON et al., 2008).

Os polímeros não biodegradáveis, como silicones e polimetilmetracrilato (PMMA), são utilizados como implantes permanentes para a reconstrução craniofacial (KRETLOW et al., 2009; ARAUJO-PIRES, 2010). Já os polímeros biodegradáveis têm sido aplicados para fixação óssea (placas e parafusos) em cirurgias ortognáticas e de trauma (FEDOROWICZ et al., 2007; BELL; KINDSFATER, 2006; LAUGHLIN et al., 2007). Exemplos disso são os ácidos poli-alfahidróxi: PGA, PLA e seu copolímero PLGA (LICKORISH; GUAN; DAVIES, 2007; KRETLOW et al., 2009). Apresentam degradação por hidrólise lenta e os seus subprodutos (ácido lático a partir do PLA e ácido glicólico do PGA), são eliminados como dióxido de carbono e água (DUNNE; CORRIGAN; RAMTOOLA, 2000; ARAUJO-PIRES, 2010).

Com o objetivo de aprimorar as propriedades físicas, biológicas e mecânicas dos biopolímeros, vários pesquisadores estão trabalhando no desenvolvimento de um biopolímero absorvível associado às cerâmicas bioativas (REZWAN et al., 2006; CHEN et al., 2007). Incorporação de polímeros naturais, tais como colagéno e o amido em sintético, também forneceram resultados promissores (FRANCO-MARQUES et al., 2009; CUNNIFFE et al., 2010; XU et al., 2011). Além disso, muitos pesquisadores buscam o desenvolvimento de revestimentos para os scaffolds poliméricos na tentativa de melhorar o efeito biológico deste substituto ósseo. 
O conceito de mineralização biomimética foi introduzida pela primeira vez por Kokubo (KOKUBO et al., 1990). Os autores observaram que a deposição de uma camada de $\mathrm{CaP}$ reduziu a encapsulação fibrosa e promoveu a diferenciação de células da medula óssea em osteoblastos. Entretanto, apesar de os revestimentos à base de $\mathrm{CaP}$ melhorarem a osteocondutividade, eles não atuam na osteocondutividade dos implantes. Para suprir essa deficiência, a associação de fatores de crescimento no tratamento dos revestimentos é uma abordagem comum (GIRONES MOLERA; MENDEZ; SAN ROMAN, 2012).

A escolha dos biopolímeros como substitutos ósseos se deve à biocompatibilidade, reprodutibilidade, porosidade, capacidade de adesão celular, além de serem manipuláveis facilmente (KLEINSCHMIDT et al., 1993; LICKORISH; GUAN; DAVIES, 2007; KRETLOW et al., 2009; ARAUJO-PIRES, 2010). Exemplos de biopolímeros utilizados como substitutos tissulares são o ácido polilático (PLA), ácido glicólico (PGA), ácido polilático-coglicólico (PLGA), polietileno, policaprolactona (PCL) e polimetilmetracrilato (PMMA) (KRETLOW et al., 2009; ARAUJO-PIRES, 2010). Podem ser usados como um arcabouço tecidual ou como carreador de fatores de crescimento ou outros biomateriais. Os Ácidos polilático e poliglicólico são os polímeros sintéticos mais utilizados e permitem um melhor controle dos riscos biológicos, em relação aos enxertos naturais, e das suas propriedades físico-químicas (MISCH; DIETSH, 1993). O Ácido polilático-coglicólico (PLGA) é um polímero biodegradável que tem sido estudado extensivamente desde os anos 60, é comumente usado em fios de sutura (BENICEWICZ; HOPPER, 1991) e como meio de fornecimento de medicação (JAIN, 2000). Implantes ósseos de PLGA têm demonstrado capacidade de induzir uma neoformação óssea mais rápida em comparação com controles (sem a sua utilização), especialmente, quando o volume do material é relativamente pequeno (KLEINSCHMIDT et al., 1993).

Autores avaliaram microscopicamente o comportamento do Fisiograft® (Ghimas SpA Casalecchio di Reno, Itália) isoladamente ou associado ao Bio-Oss® (Geistlisch Farmacêutica, Wolhusen, Suíça), após cirurgias de levantamento de seio maxilar de 16 pacientes e observaram ausência de reação inflamatória em todas as amostras (ZAFFE, et al., 2005). Fisiograft ${ }^{\circledR}$ (Ghimas SpA Casalecchio di Reno, Itália) estava presente após sete meses do procedimento cirúrgico e o osso neoformado com ou sem grânulos de Bio-Oss® (Geistlisch Farmacêutica, Wolhusen, Suíça) mostrou-se dentro do conjuntivo, apresentando estrutura primária de osso imaturo, além de uma boa quantidade de osso lamelar. Sendo assim, os autores concluíram que Fisiograft ${ }^{\circledR}$ (Ghimas SpA Casalecchio di Reno, Itália) pode 
ser considerado como uma opção na terapia regenerativa óssea por demonstrar capacidade osteopromotora (ZAFFE, et al., 2005).

\subsection{OsteoScaf ${ }^{\mathrm{TM}}$}

Um substituto ósseo polimérico, biodegradável, biocompatível e osteocondutor formado pela união do PLGA com duas fases de $\mathrm{CaP}$ e uma camada mais externa de $\mathrm{CaP}$, de 3 a $5 \mu \mathrm{m}$ de espessura, foi desenvolvido e seu nome comercial é OsteoScafTM (BoneTec Corp - TRT, Toronto, Canadá) (GUAN; DAVIES, 2004; LICKORISH; GUAN; DAVIES, 2007). OsteoScaf ${ }^{\mathrm{TM}}$ (BoneTec Corp - TRT, Toronto, Canadá) é fabricado por um processo de lixiviação e inversão de fases, a partir de PLGA e duas fases de CaP, sendo ambas reabsorvidas por osteoclastos: a primeira incorporada à estrutura do polímero e a segunda, uma camada de revestimento. A camada mais externa, de 3 a $5 \mu \mathrm{m}$ de espessura, anula uma possível resposta de corpo estranho, a qual é comumente vista na presença de materiais poliméricos (GUAN; DAVIES, 2004; LICKORISH; GUAN; DAVIES, 2007; ARAUJOPIRES, 2010). O OsteoScaf ${ }^{\mathrm{TM}}$ (BoneTec Corp - TRT, Toronto, Canadá) apresenta, ainda, resistência mecânica suficiente para manipulação cirúrgica e pode ser facilmente fabricado, conforme a forma e porosidade desejadas (GUAN; DAVIES, 2004; LICKORISH; GUAN; DAVIES, 2007; ARAUJO-PIRES, 2010). Os aspectos de sua porosidade, em torno de $81 \%$ a $91 \%$ e tamanho entre 350 e $1200 \mu$ m, auxiliam a sua capacidade de absorção de sangue, favorecendo a retenção de coágulo e resultando num suporte osteocondutor para o crescimento do osso hospedeiro (LICKORISH; GUAN; DAVIES, 2007). Estudos revelaram se tratar de uma matriz trifásica, com macroporos altamente interconectados, totalmente reabsorvível. Matrizes tridimensionais (scaffolds) feitas deste material, com porosidade similar ao osso trabecular humano (GUAN; DAVIES, 2004; LICKORISH; GUAN; DAVIES, 2007), têm mostrado crescimento ósseo tanto in vitro como in vivo e oferecem grande potencial para aplicação em bioengenharia (CANCEDDA, et al., 2003; JABBARZADEH et al., 2008; KARP; SHOICHET; DAVIES, 2003; ISHAUG-RILEY et al., 1997; HOLY; SHOICHET; DAVIES, 2000). Alguns estudos em animais revelaram biocompatibilidade, osteoindução e osteocondução na utilização do OsteoScaf ${ }^{\mathrm{TM}}$ (SHEA et al., 2000; FIALKOV et al., 2003; GOMI et al., 2004; KARP et al., 2003; SALGADO et al., 2007). Também pode ser usado como um biomaterial por si só, servindo como um retentor de coágulo e dispositivo de suporte para hospedar o crescimento ósseo, ou como um carregador de células e fatores de crescimento. 
O OsteoScaf ${ }^{\mathrm{TM}}$ (BoneTec Corp - TRT, Toronto, Canadá) é um composto polimérico formado por PLGA na proporção 75/25, com uma viscosidade de 1,33dL (Birmingham Polymers Inc., Birmingham, EUA); associado ao fosfato tetracálcio (Taihei chemical Industrial Co., Osaka, Japão); fosfato dicálcio anidro e dimetilsulfóxido (Sigma Chemical Co., St. Louis, EUA). Sua porosidade é formada pela adição de partículas de açúcar e, na sequência, sua remoção por lixiviação. O tamanho das partículas pode variar de acordo com a necessidade, sendo de 0,59-0,85mm, 0,85-1,18mm;0,85-2,0mm; e 1,18-2,0mm (GUAN; DAVIES, 2004). As partículas de CaP apresentam tamanho médio de 27,5 $\mu$ m e são formadas pela mistura equimolar de fosfato tetracálcio e fosfato dicálcio anidro com água destilada deionizada (ddH2O) a 100\% de humidade relativa, por 24 horas e, na sequência, o material é peneirado utilizando-se peneiras específicas (GUAN; DAVIES, 2004; ARAUJO-PIRES, 2010).

Ao longo dos anos de estudo, realizado pelo pesquisador John Edward Davies, da Universidade de Toronto, o OsteoScaf ${ }^{\mathrm{TM}}$ (BoneTec Corp - TRT, Toronto, Canadá) sofreu uma evolução na sua apresentação no intuito de melhorar suas características como substituto ósseo. Primeiramente, o preparo da matriz tridimensional do OsteoScaf ${ }^{\mathrm{TM}}$ (BoneTec Corp TRT, Toronto, Canadá) foi uma modificação das técnicas descritas previamente na literatura (LICKORISH; GUAN; DAVIES, 2007; ARAUJO-PIRES, 2010). Inicialmente, o material era constituído apenas por um polímero (HOLY et al., 1999). Na segunda geração, foram incorporadas partículas de fosfato de cálcio (GUAN; DAVIES, 2004) e, em seguida, foi criado um revestimento único de CaP sobre o compósito PLGA/CaP (LICKORISH; GUAN; DAVIES, 2007). Estudos in vitro e in vivo (HOLY et al., 1999; HOLY; SHOICHET; DAVIES, 2000; KARP; SHOICHET; DAVIES, 2003; FIALKOV et al., 2003) demonstraram resultados promissores deste biomaterial na sua terceira geração (LICKORISH; GUAN; DAVIES, 2007) tanto em animais (LICKORISH; GUAN; DAVIES, 2007) como em humanos (DAVIES et al., 2010; ARAUJO-PIRES, 2010).

Palestra apresentada recentemente pelo pesquisador John Davies, no III International Congress of Implantology, (13-15/09/2012, Bauru, São Paulo, Brasil), demonstrou os resultados da comparação da capacidade de biodegradação entre OsteoScaf ${ }^{\mathrm{TM}}$ (BoneTec Corp - TRT, Toronto, Canadá) e Bio-Oss® (Geistlisch Farmacêutica, Wolhusen, Suíça). O estudo procurou caracterizar o grau de degradação de cada uma das três fases de OsteoScaf ${ }^{\mathrm{TM}}$ (BoneTec Corp - TRT, Toronto, Canadá) e também a sua degradação completa em comparação com o BioOss® (Geistlisch Farmacêutica, Wolhusen, Suíça). OsteoScaf ${ }^{\mathrm{TM}}$ (BoneTec Corp - TRT, Toronto, Canadá) foi produzido com tamanhos de partículas entre 
0,35-1,18mm e 1,18-2,2mm. Ambos os biomateriais foram implantados nos fêmures distais de 36 ratos. Após 1, 2, 4, 12, e 26 semanas, os fêmures foram colhidos e imagens de retroespalhamento de elétrons foram utilizadas para quantificar a área correspondente ao biomaterial restante. A degradação do Osteoscaf ${ }^{\mathrm{TM}}$ (BoneTec Corp - TRT, Toronto, Canadá) foi significativamente mais rápida comparada ao BioOss® (Geistlisch Farmacêutica, Wolhusen, Suíça). Por 26 semanas, não houve diminuição das partículas de BioOss® (Geistlisch Farmacêutica, Wolhusen, Suíça), enquanto as pequenas partículas de OsteoScaf ${ }^{\mathrm{TM}}$, (BoneTec Corp - TRT, Toronto, Canadá) diminuíram em 70\%.

Recentemente, autores realizaram um estudo em cães, utilizando a composição desse biomaterial em forma de membrana (CARLO REIS et al., 2011). O modelo analisou a regeneração periodontal de defeitos de furca classe II, tratado com esta membrana confeccionada, e demonstrou resultados satisfatórios e superiores quando comparado ao grupo controle, não tratado. Além disso mostrou ser adaptável, biodegradável e rígido o suficiente para impedir o colapso no defeito quando confeccionado para esta finalidade. Avaliação clínica, microtomografia computadorizada e microscopias eletrônica de varredura e óptica foram utilizados para a análise de dados. Volume ósseo, número e espessura trabecular foram significativamente maior no grupo tratado, enquanto separação de trabéculas foi significativamente maior no grupo controle. Novo cemento, osso, ligamento periodontal com inserções de fibras de Sharpey foram vistos apenas no grupo tratado. O resultado desse trabalho demonstrou maior regeneração periodontal do que tem sido relatado previamente com as tradicionais membranas flexíveis. Além disso, demonstrou ser um biomaterial adaptável às diferentes morfologias anatômicas (CARLO REIS et al., 2011).

A utilização do OsteoScaf ${ }^{\mathrm{TM}}$ (BoneTec Corp - TRT, Toronto, Canadá) implantado na forma de cilindros, com duas porosidades diferentes, em alvéolos de dentes anteriores superiores humanos, imediatamente após exodontia, reduziu a perda óssea alveolar durante o processo de reparação/remodelação óssea pós-exodôntica, aos 120 dias de pós-operatório, quando comparado com o controle (apenas coágulo sanguíneo), em humanos (ARAUJOPIRES, 2010). Dez pacientes (32 alvéolos) fizeram parte desse estudo, onde 16 alveólos receberam o implante de OsteoScaf ${ }^{\mathrm{TM}}$ (BoneTec Corp - TRT, Toronto, Canadá). A análise quantitativa das microtomografias computadorizadas demonstraram mais trabéculas ósseas e menor espaço entre elas, com OsteoScaf ${ }^{\mathrm{TM}}$ (BoneTec Corp - TRT, Toronto, Canadá) com poros menores. A análise quantitativa das tomografias computadorizadas por feixe cônico indicou menor perda óssea no grupo experimental, principalmente o OsteoScaf ${ }^{\mathrm{TM}}$ (BoneTec Corp - TRT, Toronto, Canadá) com poros maiores. A avaliação qualitativa dos cortes 
histológicos mostrou neoformação óssea justaposta ao material, demonstrando sua natureza osteocondutiva (ARAUJO-PIRES, 2010).

Em relação à utilização do OsteoScaf ${ }^{\mathrm{TM}}$ (BoneTec Corp - TRT, Toronto, Canadá) como substituto ósseo em cirurgias de levantamento de seio maxilar, clinicamente e microscopicamente, o mesmo demonstrou grande desempenho e sucesso clínico após dois anos da reabilitação final com implantes em um paciente (DAVIES et al., 2010). Nesse mesmo trabalho, foi relatado o uso bem sucedido do OsteoScaf ${ }^{\mathrm{TM}}$ (BoneTec Corp - TRT, Toronto, Canadá) na forma de cilindro em dois alvéolos previamente à instalação de implantes. Dois anos após o tratamento final, a reabilitação também demonstrou sucesso clínico. Em ambas as situações, a capacidade de biodegradação do OsteoScaf ${ }^{\mathrm{TM}}$ (BoneTec Corp - TRT, Toronto, Canadá) provou ser favorável ao crescimento de novo osso trabecular para a instalação do implante e a presença de carga funcional (DAVIES et al., 2010).

5. Fatores de crescimento utilizados como substitutos ósseos

Fatores de crescimento são proteínas responsáveis pela sinalização dos estímulos de diferenciação, proliferação, migração e adesão celular. Possuem um potencial para a aplicação na reparação óssea, pois são moléculas ativadoras biológicas capazes de induzir a formação óssea através da regulação da atividade óssea. Dentre os mais importantes utilizados com a finalidade de substitutos ósseos se destacam as proteínas ósseas morfogenéticas (BMP), os fatores de crescimento como fator de transformação do crescimento beta (TGF- $\beta$ ), fator de crescimento derivado de plaqueta (PDGF), fatores de crescimento fibroblástico (FGF), fator de crescimento semelhante à insulina tipo I e II (IGF-1 e IGF-2,) e plasma rico em plaquetas (PRP) (HENSON; BOWE; DAVIES, 2005; LAURECIN; KHAN; EL-AMIN, 2006; SCHMIDT; CHEN; LYNCH, 2006; WILLIE et al., 2010). Eles são empregados para promover o crescimento ósseo, acelerar sua maturação e podem ser aplicados isoladamente ou em combinação com outros biomateriais (ESPOSITO, 2010).

Autores, em 1979, isolaram uma glicoproteína óssea morfogenética, conhecida como BMP (Bone Morphogenetic Protein) quando estudavam o osso desmineralizado (URIST et. al.,1979). As BMPs representam citocinas multifuncionais derivadas do fator TGF- $\beta$, são capazes de recrutar células-tronco mesenquimais MSCs e estimular a diferenciação em células ósseas, resultando em neoformação óssea. Os tipos 2, 4, 6, 7 e 9 têm demonstrado atividade osteoindutora (WARIS et al., 2010; CHEN et al. 2010). Em decorrência dessa propriedade, são consideradas promissoras quando utilizadas na regeneração óssea, resultando 
em melhor qualidade óssea do enxerto (SILVA; ALBERGARIA-BARBOSA; MAZZONETTO, 2006; KOCH et al., 2010; CORREIA et al., 2012). Atualmente, pesquisadores buscam a melhor forma de aplicá-la, pois são proteínas facilmente absorvidas pelos tecidos. Alguns biomateriais osteocondutores, como a matriz óssea desmineralizada, HA, polímeros, carbonato de cálcio e CaP são utilizados como veículo carreador de BMP. (RACHMIEL; AIZENBUD; PELED, 2004; ARAUJO-PIRES, 2010).

$\mathrm{Na}$ literatura, encontram-se alguns estudos utilizando fatores de crescimento em cirurgias de levantamento de seio maxilar (MARGOLIN et al., 1998; TERHEYDEN et al., 1999; FUERST et al., 2004; ROLDÀN et al., 2004). A BMP-7 associada ao osso bovino demonstrou um resultado estatisticamente melhor quando comparada à associação de PRP com o osso bovino (ROLDÀN et al., 2004). Outros estudos demonstraram que a BMP-7 associada ao osso bovino mineralizado produziu um resultado superior comparado ao osso bovino sozinho (MARGOLIN et al., 1998; TERHEYDEN et al., 1999).

Outra fonte de proteínas ou fatores de crescimento, recentemente estudada na literatura, é o plasma rico em plaquetas (PRP) (MARX, 2004; CURI et al., 2007). Descrito desde 1970, é obtido do próprio paciente, após dupla centrifugação ativada do sangue, a qual resulta numa concentração muito elevada de plaquetas contendo várias proteínas ou fatores de crescimento (PDGF, TGF- $\beta 1$, EGF, VEGF), os quais são secretados ativamente pelas plaquetas no início do processo de cicatrização de uma ferida (SCHMITZ; HOLLINGER, 2001). Diante da grande concentração de fatores de crescimento angiogênicos e demais fatores que agem na remodelação óssea, é considerado um fator de redução de reabsorção óssea após a instalação de implantes e de ajuda na cicatrização dos tecidos moles e duros. Entretanto, a efetividade do PRP continua controversa e discutida na literatura (BOYAPATI; WANG, 2006; SCHAAF et al., 2008).

A utilização do PRP e dos demais fatores de crescimento acaba requerendo menor volume ósseo autógeno necessário nas cirurgias reconstrutivas, além de oferecer propriedades desejáveis ao processo de regeneração óssea (BETTEGA et al., 2009). Estudo clínico randomizado, avaliando 34 pacientes submetidos à cirurgia de levantamento de seio maxilar, comparou associação do PRP e osso autógeno com este último sozinho (SCHAAF et al., 2008). Resultados revelaram não haver aumento na densidade óssea nas imagens de tomografia computadorizada nem diferenças em relação ao insucesso dos implantes. Outros autores avaliaram a associação do PRP com o Bio-Oss® (Geistlisch Farmacêutica, Wolhusen, Suíça), num ensaio clínico randomizado, onde o grupo controle foi somente a utilização do Bio-Oss ${ }^{\circledR}$ (Geistlisch Farmacêutica, Wolhusen, Suíça) (TORRES, et al., 2009). Os resultados 
demonstraram uma melhora na osteocondutividade, quando Bio-Oss® foi associado ao PRP, representada pelo aumento da neoformação óssea (TORRES et al., 2009). A taxa de sobrevivência dos implantes foi de $96,2 \%$ no controle e de $98,6 \%$ no grupo da associação, porém existiram diferenças entre os lados, durante o período de controle, em 87 pacientes (TORRES et al., 2009). Entretanto, em outro estudo, não houve diferenças quando o PRP foi associado ao osso bovino mineralizado comparado com este sozinho (FÜRST et al., 2003).

Outros autores associaram o PRP com o osso autógeno removido da crista ilíaca em 18 pacientes (BETTEGA, et al., 2009). O grupo controle foi representado pelo osso autógeno. Autores concluíram que a utilização do PRP pode reduzir até $60 \%$ do volume de osso autógeno necessário para o enxerto após o procedimento de levantamento de seio maxilar, sem alterar seu comportamento ao longo do tempo. Além disso, analisando 111 implantes instalados, após um ano de controle, estes permaneceram estáveis (BETTEGA et al., 2009). Outros autores não encontraram diferença estatisticamente significante entre a associação do PRP com o osso autógeno comparado ao osso autógeno sozinho após 12 semanas (JAKSE et al., 2003). Considerando as cirurgias de levantamento de seio maxilar, um estudo em ovelhas demonstrou, em todos os cortes histológicos, semelhança na arquitetura óssea tanto no grupo com PRP quanto no controle (JAKSE et al., 2003). Outros autores também não conseguiram encontrar grandes vantagens do PRP na regeneração óssea (BUTTERFIELD et al., 2005; GRAGEDA et al., 2005; KLONGNOI et al., 2006).

Embora alguns trabalhos tenham apresentado resultados promissores quanto à utilização do PRP em cirurgias de levantamento de seio maxilar, duas revisões sistemáticas referiram que nenhum estudo apresenta vantagens na aplicação de PRP ou melhoras dos resultados nos procedimentos de levantamento de seio maxilar (ESPOSITO et al., 2009; ESPOSITO et al., 2010)

Do mesmo modo como os fatores de crescimento, os substitutos ósseos celulares são recursos realizados para obter melhor propriedade osteoindutiva e até osteogênica. Exemplo são as células-tronco, as quais podem ser utilizadas sozinhas ou associadas com um scaffold ou matriz responsável pelo suporte osteocondutor. Exemplos de células-tronco aplicadas na engenharia de tecido ósseo são as células-tronco embrionárias, células-tronco mesenquimais derivadas da medula óssea, do cordão umbilical, do tecido adiposo, do músculo e célulastronco da polpa dentária (ARAUJO-PIRES, 2010).

Por fim, o uso do osso autógeno está bem documentado e, diante das evidências científicas dos bons resultados clínicos, pode ser concluído que é ainda considerado o padrãoouro como opção de preenchimento de defeitos ósseos. Entretanto nem sempre é uma opção 
viável, como visto anteriormente, sendo a razão da existência dos substitutos ósseos. Vale ressaltar que alguns trabalhos referem não existir necessidade de preenchimento após o levantamento de seio maxilar (CORREIA et al., 2012). São necessários mais estudos padronizados analisando o comportamento do implante a longo prazo, após o procedimento de levantamento de seio maxilar, para que se possa concluir melhor a respeito dos substitutos ósseos. 
3 PROPOSIÇÃo 



\section{PROPOSIÇAO}

O objetivo deste trabalho foi:

3.1 Avaliar o comportamento osteocondutor do OsteoScaf ${ }^{\mathrm{TM}}$ (BoneTec Corp - TRT, Toronto, Canadá) como substituto ósseo, em cirurgias de levantamento de seios maxilares em coelhos.

3.2 Comparar este comportamento com o do osso autógeno e outros dois substitutos ósseos não totalmente biodegradáveis: Bio-Oss®) (Geistlich Biomaterials, Wolhusen, CH, Suíça) e BoneCeramic ${ }^{\circledR}$ (Instituto Straumann AG, Basel, Suíça). 

4 MATERIAl e MÉtodos 



\section{MATERIAL E MÉTODOS}

\subsection{Substitutos ósseos utilizados}

\subsubsection{OsteoScaf ${ }^{\mathrm{TM}}$}

O OsteoScaf ${ }^{\mathrm{TM}}$ (BoneTec Corp - TRT, Toronto, Canadá) é um biomaterial polimérico totalmente biodegradável, fabricado a partir de ácido poliláctico-coglicólico (PLGA), 75/25, com 2 fases de fosfato de cálcio $(\mathrm{CaP})$ reabsorvíveis pelos osteoclastos: uma derivada de partículas de cimento CaP com um tamanho médio de $25 \mu \mathrm{m}$ no interior da fase de PLGA, e

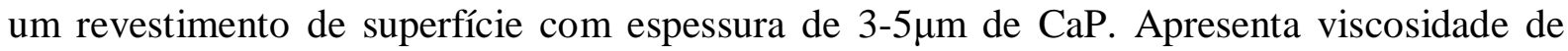
1,33dL (Birmingham Polymers Inc., Birmingham, EUA). A porosidade é formada pela adição de partículas de açúcar, que são removidas, ao final, por lixiviação. Essas partículas apresentam-se de vários tamanhos: 0,59-0,85mm, 0,85-1,18mm, 0,85-2,0mm e 1,18-2,0mm, porém, neste estudo, foram utilizadas partículas de 0,35-1,18mm (Figura 1A). As partículas do cimento de $\mathrm{CaP}$ são preparadas através de uma mistura equimolar de fosfato tetracálcio e fosfato dicálcio anidro com água destilada deionizada (ddH2O) a 100\% de umidade relativa, por 24 horas. O reagente é moído e peneirado através de uma série de peneiras feitas sob medida. Dessa forma, obtêm-se partículas de CaP com tamanho médio de 27,5 $\mu \mathrm{m}$. OsteoScaf $^{\mathrm{TM}}$ (BoneTec Corp - TRT, Toronto, Canadá), exibe osteocondutividade, força mecânica apropriada e ausência de resposta inflamatória crônica (LICKORISH; GUAN; DAVIES, 2007; DAVIES et al., 2010).

\subsubsection{Bio-Oss®}

Bio-Oss® particulado (Geistlich Biomaterials, Wolhusen, $\mathrm{CH}$, Suíça) é um osso bovino inorgânico com composição semelhante à arquitetura de osso esponjoso natural e propriedades osteocondutora e antigênica. O tamanho de partícula escolhida neste estudo foi de 0,25 a 1,0 mm (Figura 1B). Existem muitos estudos bem documentados utilizando BioOss ${ }^{\circledR}$ como material para enxerto, especialmente em levantamento de seio maxilar, com resultados promissores (HALLMAN; NORDIN, 2002; VALENTINI; ABENSUR, 2003; YILDIRIM et al., 2000; HÜRZELER et al., 1997; FROUM et al., 2006; FROUM et al., 2008; ARTZI et al., 2001). A propriedade de degradação tem sido discutida na literatura, mas os 
estudos mostraram uma degradação parcial com o tempo (SKOGLUND; HISING; YOUNG, 1997; VALENTINI; ABENSUR, 2003).

\subsubsection{BoneCeramic $®$}

BoneCeramic ${ }^{\circledR}$ (Instituto Straumann AG, Basel, Suíça) é um substituto ósseo na forma particulada, completamente sintético, composto por fosfato de cálcio bifásico, compreendendo $60 \%$ de hidroxiapatita (HA) e $40 \%$ de beta-fosfato tricálcico (TCP- $\beta$ ). Apresenta $90 \%$ de porosidade, com poros interconectados de $100-500 \mu \mathrm{m}$ de diâmetro e, no presente estudo, foi avaliado o tamanho de grânulo de 0,5-1.0mm de diâmetro (Figura 1C). As propriedades osteocondutora e biocompatibilidade do fosfato de cálcio bifásico foram demonstradas em estudos clínicos e experimentais (CORDARO et al., 2010; SCHWARTZ et al., 1999; PIATELLI; SCARANO; MANGANO, 1996; COVANI et al., 2011; DALCUSI; GOYENVALLE; AGUADO, 1999). Avaliação clínica, após 15 meses de levantamento do seio maxilar usando BoneCeramic ${ }^{\circ}$, mostrou aplicação clínica eficaz (PIATTELLI; SCARANO; MANGANO, 1996). Em relação a sua degradação, estudo retrospectivo clínico mostrou ser parcialmente degradável (COVANI et al., 2011).

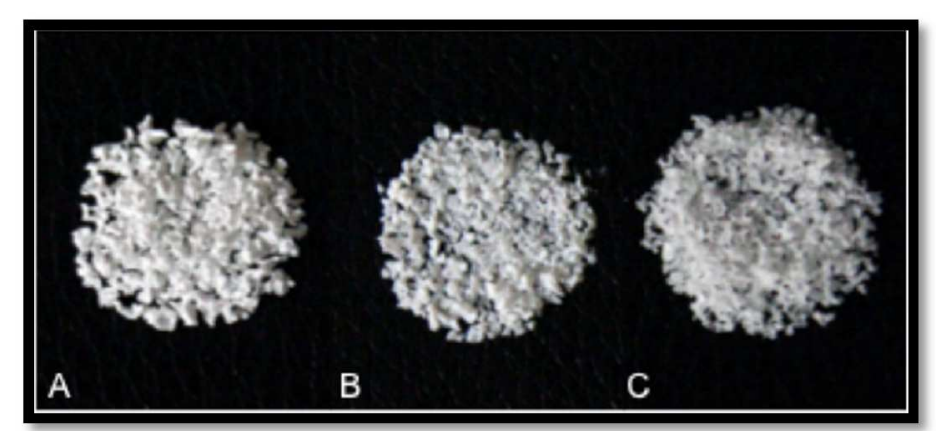

Figura 1 - A. OsteoScaf ${ }^{\mathrm{TM}}$, B. Bio-Oss ${ }^{\circledR}$, C. BoneCeramic $®$

\subsection{Metodologia}

Após o projeto ter sido aprovado pelo Comitê de Ética e Pesquisa com Animais (Processo: 015/2010) a parte experimental cirúrgica foi realizada. A metodologia de levantamento de seio maxilar em coelhos, realizada neste trabalho, baseou-se na técnica descrita por Asai em 2002 (ASAI; SHIMIZU; OOYA, 2002). Foram utilizados 66 coelhos albinos (Oryctolagus cuniculus, New Zealand) machos, com peso aproximado de $3 \mathrm{Kg}$. Foram 
utilizados somente coelhos machos para evitar as influência das variações hormonais sobre o processo de reparo. Os animais foram alimentados com ração sólida e água à vontade.

\subsubsection{Parte experimental cirúrgica}

A parte experimental cirúrgica foi realizada no Biotério da Faculdade de Odontologia de Bauru, Universidade de São Paulo. Os animais foram submetidos à sedação com injeção intramuscular de cloridrato de xilazina na dose de $0,28 \mathrm{ml} / \mathrm{Kg}$ de peso e anestesiados com cloridrato de quetamina na dose de $0,39 \mathrm{ml} / \mathrm{Kg}$ de peso. Foi feita a tricotomia na região da face e da área doadora do enxerto, no caso dos grupos que receberam enxerto autógeno e, em seguida, a antisepsia com solução aquosa de polivinilpirrolidona (PVPI tópico) (Dermoidine Gessy Lever Industrial Ltda) (Figura 2).

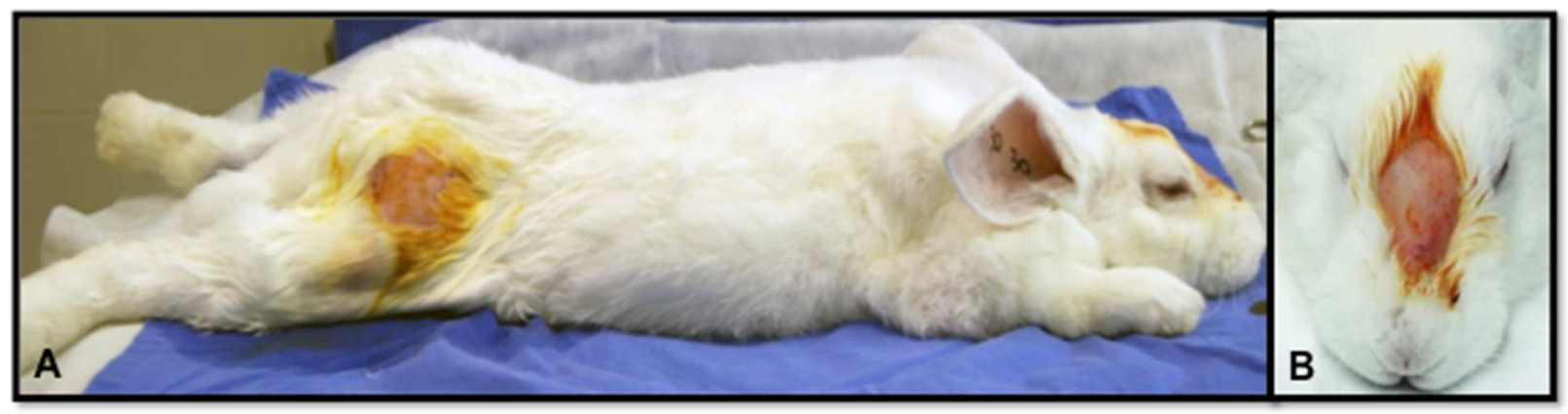

Figura 2 - Imagem do animal após tricotomia e antisepsia nas áreas A. doadora e B. receptora

\subsubsection{Preparo da área doadora e remoção do enxerto}

Para o preparo da área doadora, foi aplicado $1 \mathrm{~mL}$ de anestésico local articaína $4 \%$ com adrenalina 1:100.000 (Articaíne 100, DFL, Rio de Janeiro, Brasil) para diminuir o sangramento da região (Figura 3). Em seguida, foi feita uma incisão com lâmina 10, com cerca de $1,5 \mathrm{~cm}$ na pele sobre a crista ilíaca direita e a dissecção do tecido ósseo muscular até a exposição óssea (Figura 4A e 4B). Com uma pinça goiva, foi removida uma porção de osso

autógeno córtico-medular (Figura 5). Após a coleta do enxerto, o tecido muscular foi suturado com fio de sutura reabsorvível 4-0 (Vicryl (poliglactina 910), Johnson \& Jonhson, São Paulo, Brasil) e em seguida, a pele, com fio de sutura de seda 4-0 (Ethicon (seda), Johnson \& Johnson, São Paulo, Brasil) (Figura 6A e 6B). 



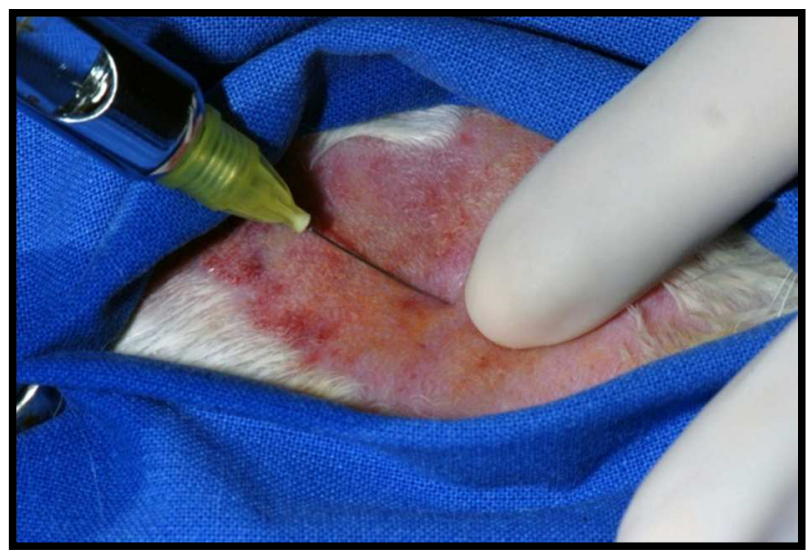

Figura 3 - Anestesia infiltrativa na região da pele que recobre a crista ilíaca direita

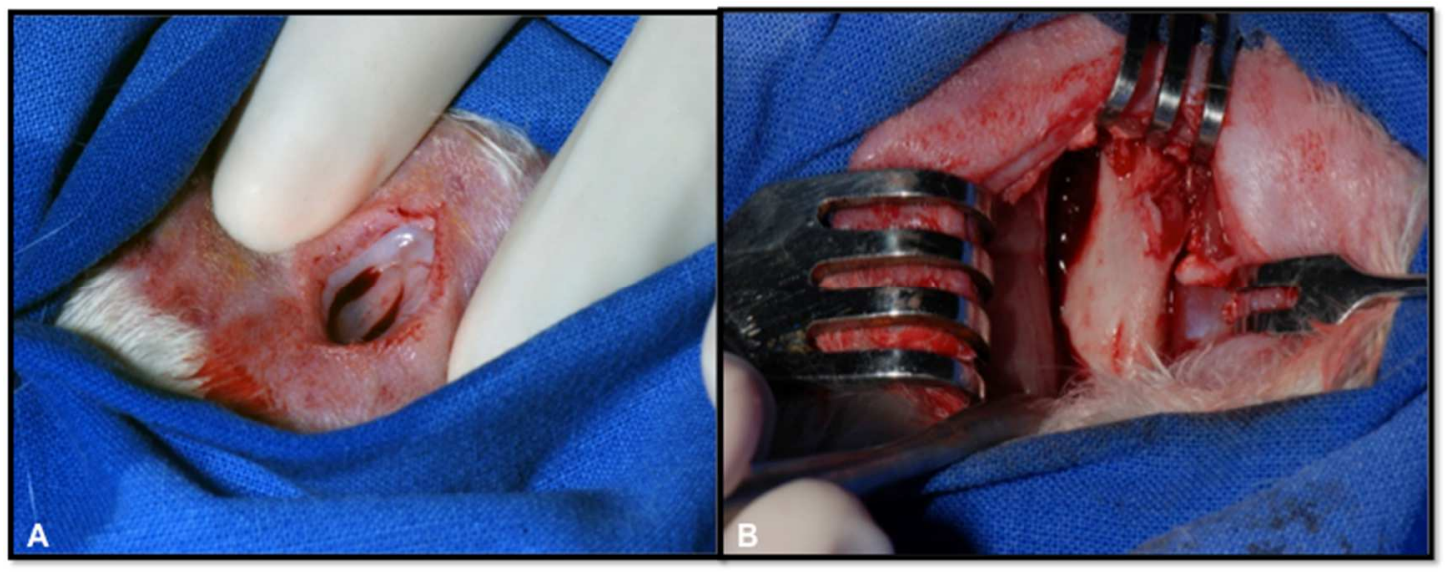

Figura 4 - A. Incisão por planos e B. descolamento do periósteo para exposição da crista ilíaca

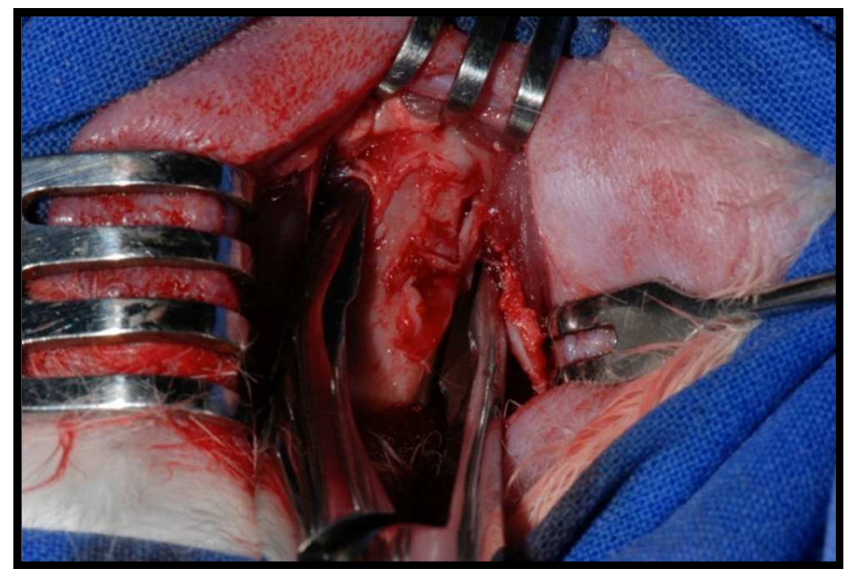

Figura 5 - Remoção do enxerto ósseo com pinça goiva 



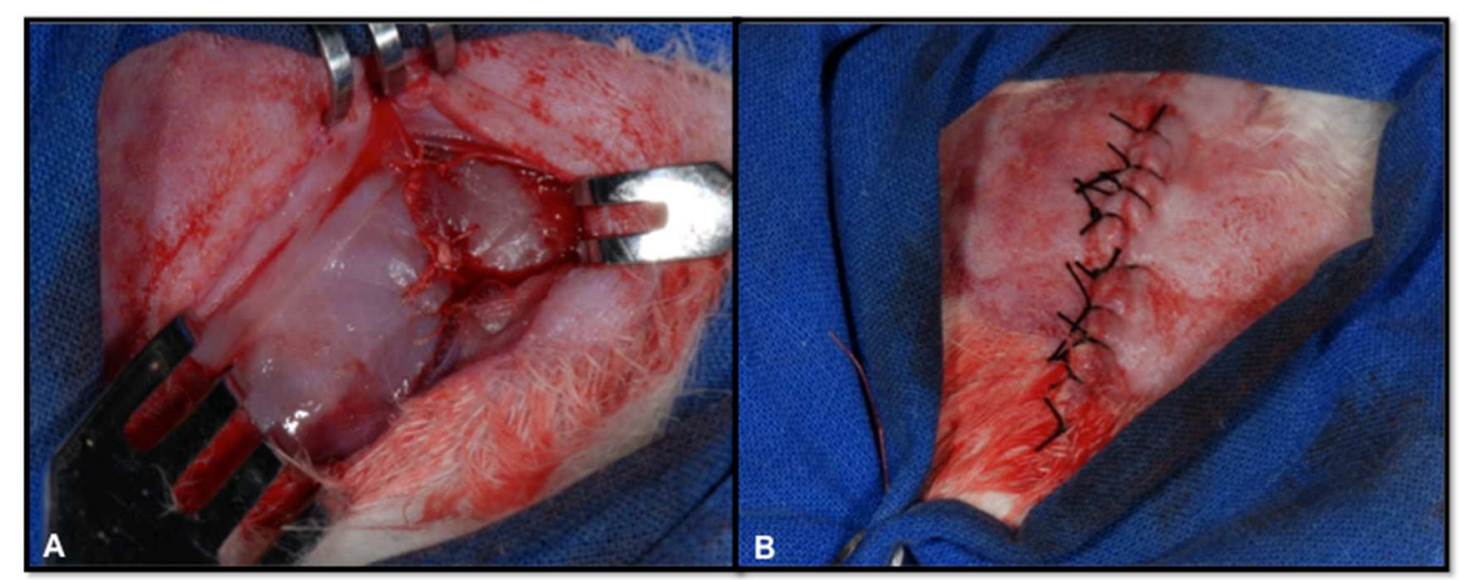

Figura 6 - A. Sutura do plano muscular com Vicryl 4.0 e B. da pele com seda 4.0

\subsubsection{Preparo da área receptora: Levantamento do seio maxilar}

Para o procedimento de levantamento do seio maxilar, foi aplicado $1 \mathrm{ml}$ de anestésico local articaína 4\% com adrenalina 1:100.000 (Articaíne 100, DFL, Rio de Janeiro, Brasil) para diminuir o sangramento da região facial (Figura 7). Utilizando uma lâmina 10, uma incisão de $2 \mathrm{~cm}$ foi realizada perpendicularmente à sutura naso-incisal (Figura 8A, 8B) e, em seguida, o descolamento do periósteo (Figura 9). Para o acesso aos seios maxilares direito e esquerdo, foi criada uma janela, $2,5 \mathrm{~cm}$ distante da porção mais anterior do osso nasal e $5 \mathrm{~mm}$ lateralmente à sutura nasal, de cada lado do animal, utilizando uma broca trefina de $5 \mathrm{~mm}$ de diâmetro (Figura 10), sob irrigação de solução salina estéril abundante, utilizando um motor de baixa rotação (250 RPM) (TC-Motor 3.000, Nouvag AG/AS, Suíça) (Figura 11). A janela foi removida e a membrana sinusal foi delicadamente elevada com a utilização de uma cureta de Lucas, para prevenir perfuração e possibilitar o preenchimento com os materiais (Figura 12). O acesso ao seio maxilar foi feito bilateralmente em todos os animais (Figura 13). A membrana sinusal sofreu pequena perfuração (1-2mm) em 7 seios maxilares, as quais foram delicadamente dobradas e afastadas previamente à inserção do substituto ósseo. 



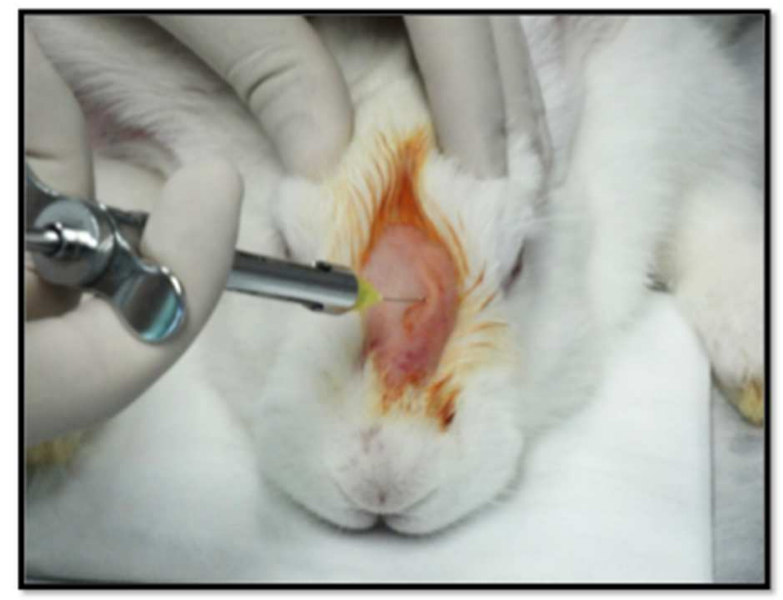

Figura 7 - Anestesia infiltrativa na região facial receptora

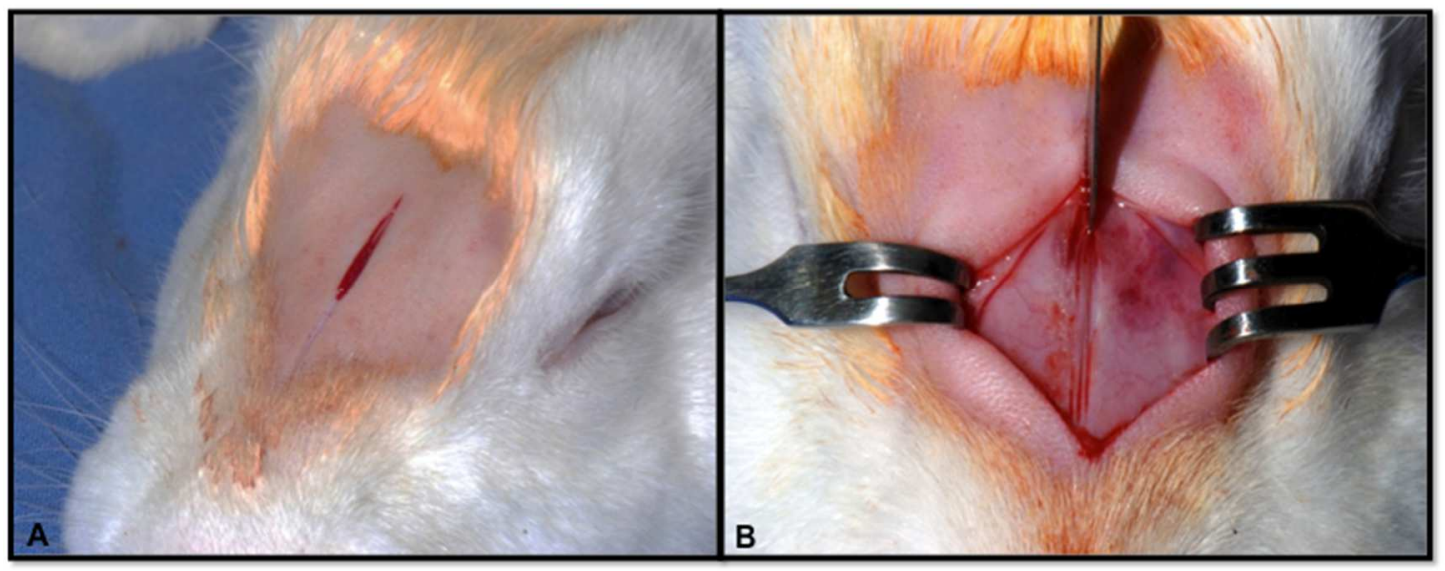

Figura 8 - A. Incisão da pele e B. do periósteo

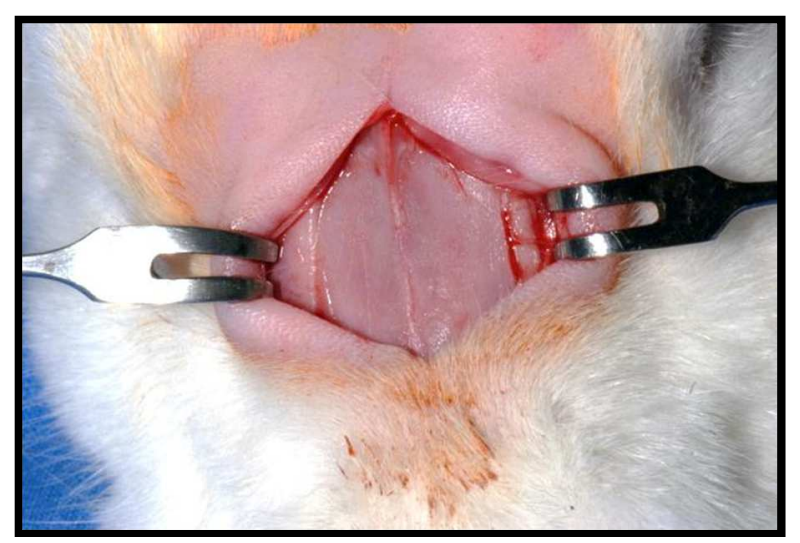

Figura 9 - Descolamento periosteal 



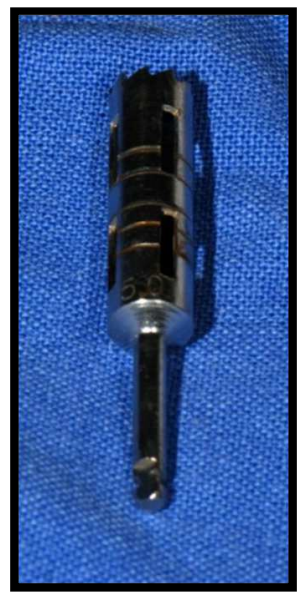

Figura 10 - Trefina utilizada no acesso ao seio maxilar

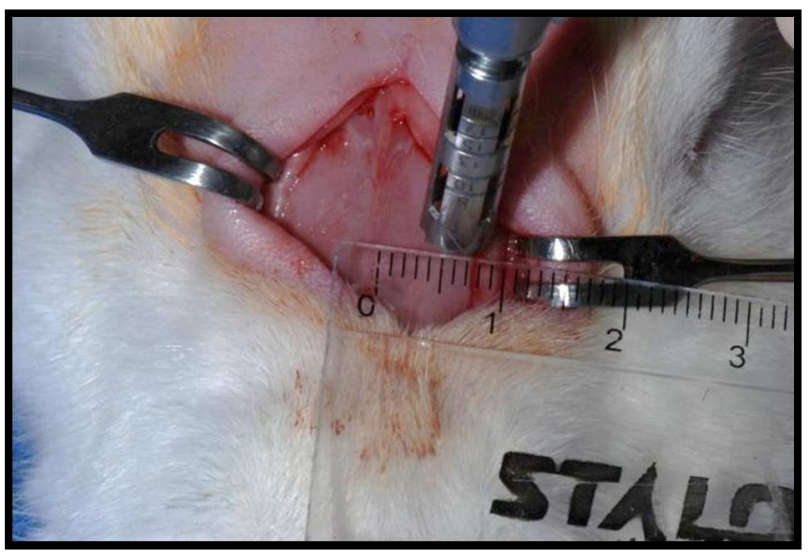

Figura 11 - Acesso ao seio maxilar esquerdo, aproximadamente $5 \mathrm{~mm}$ da sutura nasal

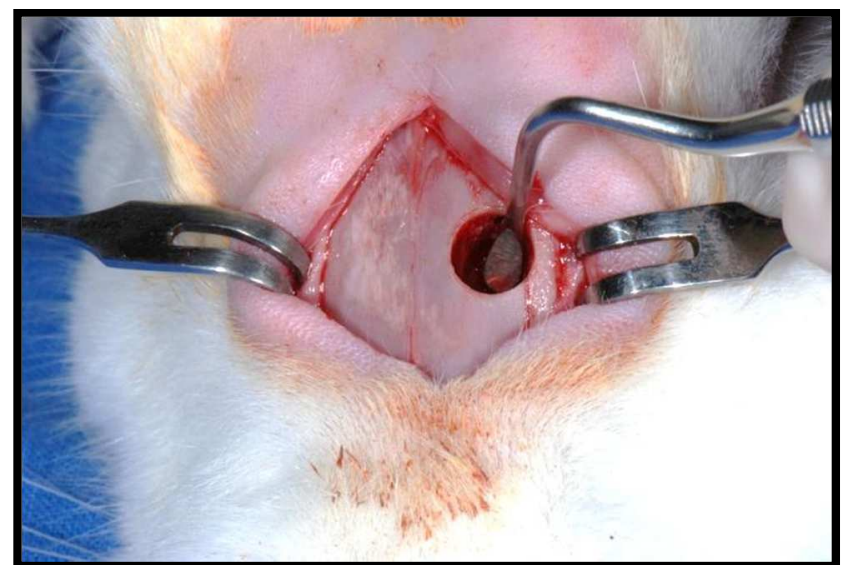

Figura 12 - Levantamento da mucosa sinusal 



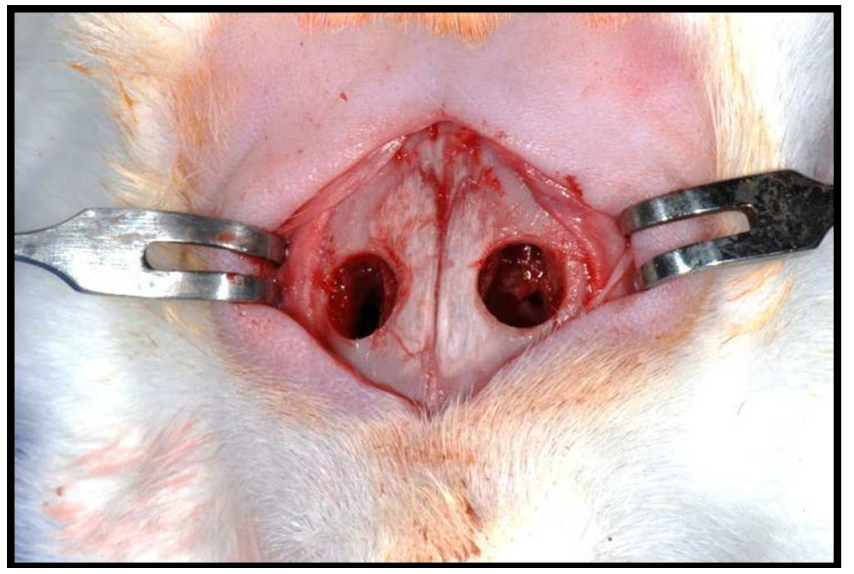

Figura 13 - Acesso bilateral aos seios maxilares direito e esquerdo

\subsubsection{Preenchimento do seio maxilar}

Os 66 animais, perfazendo um total de 132 seios maxilares, receberam em cada seio maxilar o enxerto ou substituto ósseo, no volume de $0,3 \mathrm{ml}$ distribuídos aleatoriamente. Os grupos foram divididos em 1. OsteoScaf ${ }^{\mathrm{TM}}$ granulado, 2. Bio-Oss ${ }^{\circledR}, 3$. BoneCeramic ${ }^{\circledR}$ e 4. enxerto osso autógeno removido da crista ilíaca. Ainda, as análises foram divididas em 3 períodos: 2, 4 e 8 semanas, portanto, 11 seios maxilares de cada grupo, por período foram submetidos ao procedimento. A distribuição dos grupos foi feita de forma que houvesse uma combinação entre todos os grupos experimentais. O osso autógeno córtico-medular, removido da crista ilíaca, foi triturado num triturador específico (Quétin Bone-Mill, Germany) para o preparo do enxerto (Figura 14).

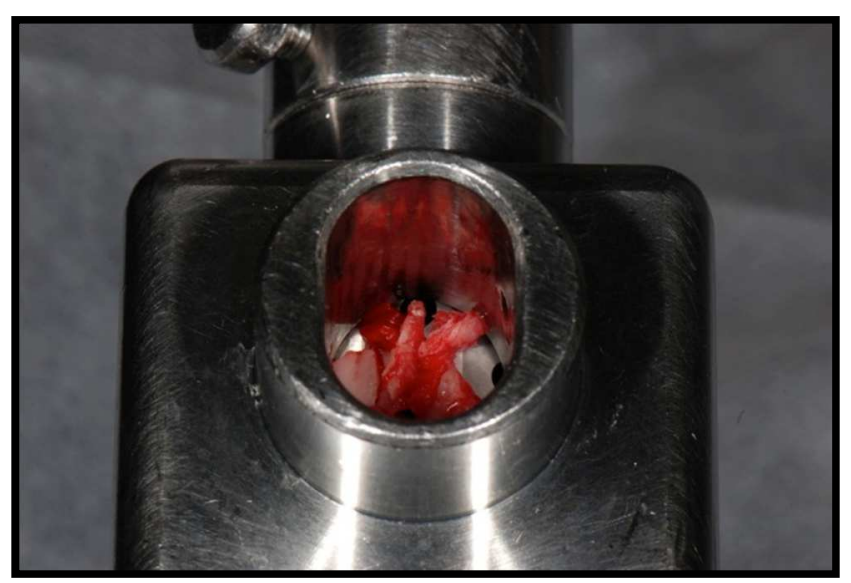

Figura 14 - Osso autógeno posicionado no triturador de osso 

Uma seringa de $1 \mathrm{ml}$ foi utilizada para a padronização da quantidade de material para o preenchimento de $0,3 \mathrm{ml}$ em cada seio maxilar (Figura 15). O diâmetro da seringa coincidiu com a abertura do acesso, facilitando o procedimento de preenchimento (Figura 16).

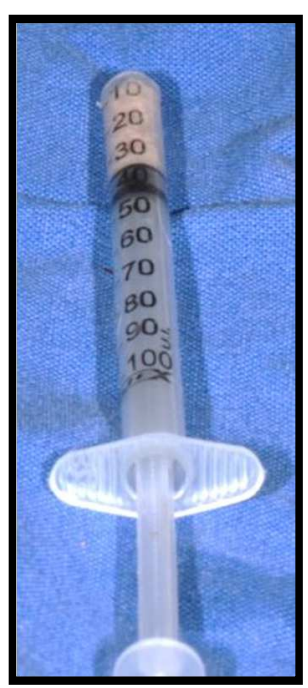

Figura 15 - Seringa com a quantidade padronizada do substituto ou enxerto ósseo

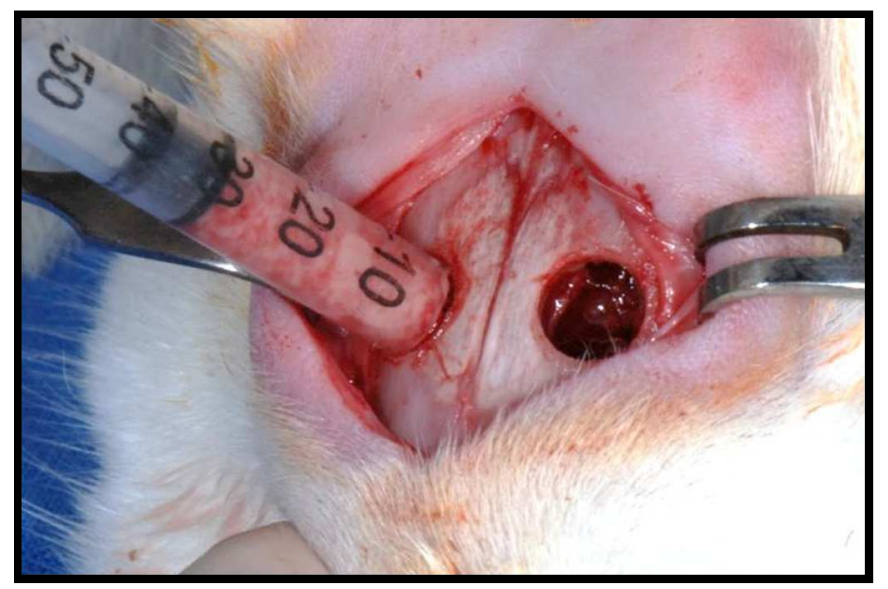

Figura 16 - Preenchimento do seio maxilar direito com osso autógeno triturado

Após os seios maxilares serem preenchidos (Figura 17), uma membrana de colágeno bovino reabsorvível (Geistlich, Bio-Gide) foi posicionada acima das janelas ósseas, para impedir a interferência de outros tecidos no interior da área estudada (Figura 18). 



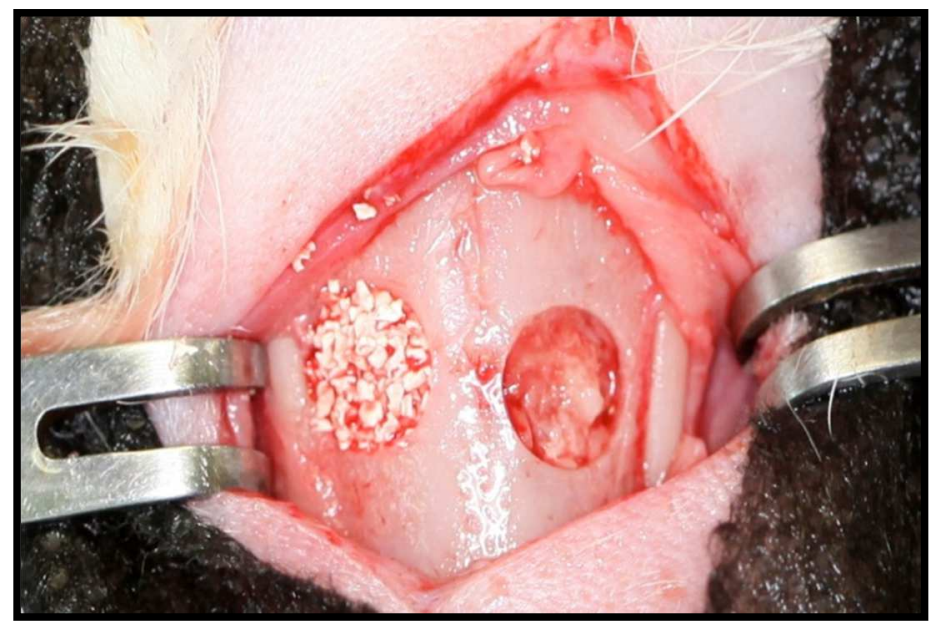

Figura 17 - Seio maxilar direito preenchido com OsteoScaf ${ }^{\mathrm{TM}}$ e esquerdo com osso autógeno

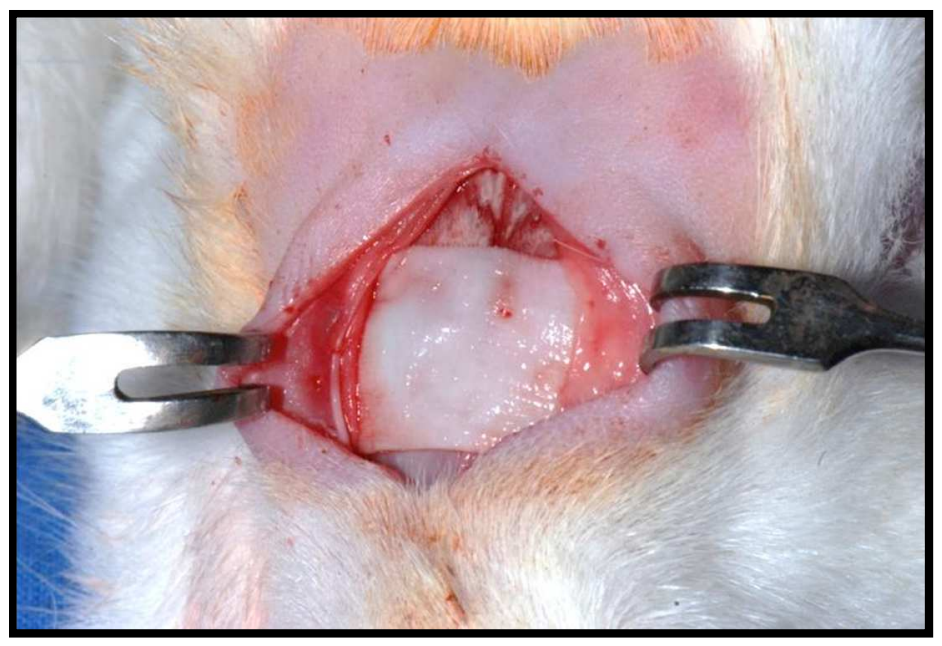

Figura 18 - Posicionamento da membrana

Sutura do periósteo e da pele foi feita com fio Vicryl 4.0 (Vicryl (poliglactina 910), Johnson \& Jonhson, São Paulo, Brasil) e, em seguida, a pele, com fio de sutura de seda 4-0 (Ethicon, Johnson \& Johnson, São Paulo, Brasil) (Figura 19). 



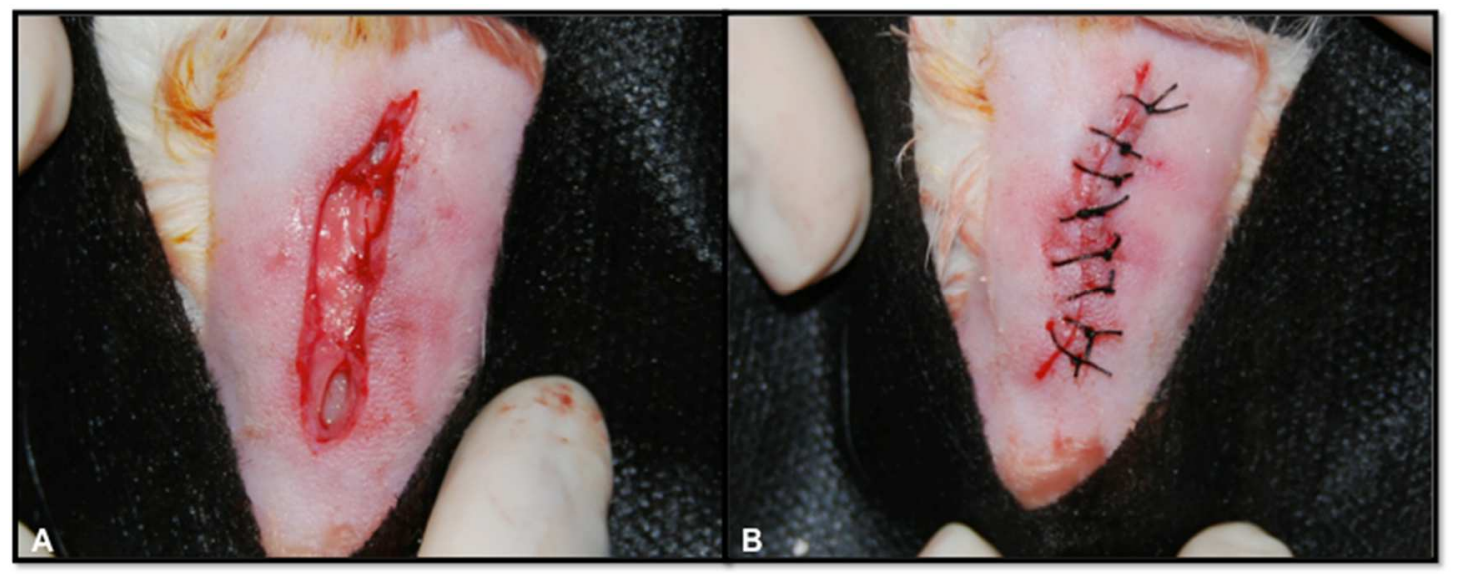

Figura 19 - A. Sutura do periósteo com Vicryl 4.0 e B. da pele com Seda 4.0

\subsubsection{Cuidados pós-operatório}

Imediatamente após a cirurgia, os animais receberam uma dose de antibiótico à base de benzilpenicilina, bactericida, de amplo espectro e ação prolongada (Shotapen L. A., Virbac). Foi dada uma dose profilática de $2 \mathrm{ml}$ e após 5 dias, uma nova dose. Além disso, foi administrado anti-inflamatório não esteroidal (Ketofen 1\% (Cetoprofeno), Merial Saúde Animal Ltda), uma dose imediata e por mais três dias o equivalente a 0,2 $\mathrm{ml}$ por $\mathrm{kg}$ de peso. Ambos os medicamentos foram administrados via parenteral, intramuscular. Ao administrar o anti-inflamatório e antibiótico no pós-operatório, não houve a necessidade de sedação. No momento da visita e medicação, as feridas foram observadas diariamente e também foi feita a antissepsia da ferida com PVPI embebido numa gaze estéril.

Os animais que foram submetidos à remoção de osso autógeno, nos primeiros dias seguidos do procedimento, apresentavam restrição de movimentos na gaiola em decorrência do edema e da sensibilidade da área operada. Porém, de 4 a 7 dias, o comportamento deles retornou ao normal. A área doadora, em duas semanas, apresentou cicatrização completa, com crescimento de pelos sobre a região operada. A maioria dos pontos foram removidos sem sedação, após 5 dias. $\mathrm{Na}$ área receptora, após uma semana, os pontos já estavam bem reabsorvidos e a ferida bem cicatrizada. Após duas semanas, a ferida já estava completamente cicatrizada, com formação de pelos no local recobrindo a área operada. Em ambos os locais operados não houve nenhum sinal de infecção. Os sete animais que sofreram perfuração da membrana sinusal não apresentaram nenhum sinal e/ou sintoma de infecção. 

De 66 animais operados inicialmente, morreram quatro. Nenhum animal morreu imediatamente após o procedimento cirúrgico. Dois animais foram a óbito de 3 a 4 dias após a cirurgia e ambos haviam sido submetidos à cirurgia da crista ilíaca.

Diariamente, a alimentação foi notada como um parâmetro saudável, e estes animais que foram a óbito não se alimentaram nos dias seguintes ao procedimento, e apresentaram dificuldade de movimento na perna envolvida. Outros dois animais morreram após 2 semanas de pós-operatório por complicações gastrointestinais. Os mesmos não apresentaram complicações imediatas relacionadas à cirurgia. Foram substituídos dois animais, restando 64 animais para a análise do projeto. Destes, 53 animais (106 seios maxilares) foram analisados microscopicamente e 11 (22 seios maxilares), molecularmente. Abaixo se encontra um esquema ilustrativo da divisão das amostras, por análise (Figura 20).

\begin{tabular}{|c|c|c|c|c|}
\hline Análises & 2 semanas & 4 semanas & 8 semanas & Total \\
\hline $\begin{array}{l}\text { Qualitativas } \\
\text { TCFC } \\
\text { MicroCt }\end{array}$ & $\begin{array}{l}\text { OS }(N=9) \\
\text { BI }(N=9) \\
\text { BO }(N=9) \\
\text { AU }(N=9)\end{array}$ & $\begin{array}{l}\text { OS }(N=8) \\
\text { BI }(N=9) \\
\text { BO }(N=9) \\
\text { AU }(N=8)\end{array}$ & $\begin{array}{l}\text { OS }(N=9) \\
\text { BI }(N=9) \\
\text { BO }(N=9) \\
\text { AU }(N=9)\end{array}$ & $\begin{array}{l}106 \text { espécimes } \\
\text { (53 animais) }\end{array}$ \\
\hline $\begin{array}{l}\text { Quantitativa } \\
\text { Histomorfometria } \\
\text { MicroCt }\end{array}$ & $\begin{array}{l}\text { OS }(N=6) \\
\text { BI }(N=6) \\
\text { BO }(N=6) \\
\text { AU }(N=6)\end{array}$ & $\begin{array}{ll}\text { OS } & (N=6) \\
\text { BI } & (N=6) \\
\text { BO }(N=6) \\
\text { AU }(N=6)\end{array}$ & $\begin{array}{ll}\text { OS } & (N=6) \\
B I & (N=6) \\
B O & (N=6) \\
A U & (N=6)\end{array}$ & $\begin{array}{c}72 \text { espécimes } \\
\text { (Selecionados do } \\
\text { total) }\end{array}$ \\
\hline $\begin{array}{l}\text { Quantitativa } \\
\text { Histomorfometria } \\
\text { Microscopia } \\
\text { Confocal }\end{array}$ & $\begin{array}{l}\text { OS }(N=3) \\
\text { BI }(N=3) \\
\text { BO }(N=3) \\
\text { AU }(N=3)\end{array}$ & $\begin{array}{l}\text { OS }(N=3) \\
\text { BI }(N=3) \\
\text { BO }(N=3) \\
\text { AU }(N=3)\end{array}$ & $\begin{array}{l}\text { OS }(N=3) \\
\text { BI }(N=3) \\
\text { BO }(N=3) \\
\text { AU }(N=3)\end{array}$ & $\begin{array}{c}36 \text { espécimes } \\
\text { (Selecionados do } \\
\text { total) }\end{array}$ \\
\hline $\begin{array}{c}\text { Quantitativa } \\
\text { Análise Molecular }\end{array}$ & $\begin{array}{l}\text { OS }(N=3) \\
\text { BI }(N=2) \\
\text { BO }(N=2) \\
\text { AU }(N=1)\end{array}$ & $\begin{array}{ll}\text { OS } & (N=2) \\
B I & (N=2) \\
\text { BO }(N=1) \\
\text { AU }(N=1)\end{array}$ & $\begin{array}{ll}\text { OS } & (N=3) \\
B I & (N=2) \\
B O & (N=2) \\
\text { AU } & (N=1)\end{array}$ & 22 espécimes \\
\hline Amostra Total & & & & $\begin{array}{l}128 \text { espécimes } \\
\text { (64 animais) }\end{array}$ \\
\hline
\end{tabular}

Figura 20 - Distribuições das amostras em cada análise dos resultados

Com o objetivo de se realizar uma análise quantitativa da neoformação óssea em microscópio confocal, 3 animais por grupo, foram selecionados para receber injeções intramusculares de marcadores fluorocromos de neoformação óssea: tetraciclina $(25 \mathrm{mg} / \mathrm{kg}$ de 
peso) aos 10 dias, alizarina (30mg/kg de peso) aos 25 dias e calceína (20mg/kg de peso) aos 45 dias.

\subsubsection{Eutanásia}

A eutanásia dos animais foi realizada após 2, 4 e 8 semanas após o procedimento cirúrgico. Foi feita sob sedação, anestesia profunda intramuscular e, logo após, injeção cardíaca de cloreto de potássio a 19\% (Samtec, Ribeirão Preto, SP, Brasil) de acordo com a resolução número 714 do Conselho Federal de Medicina Veterinária. As amostras da análise microscópica consistiram na maxila dissecada cuidadosamente e armazenadas em formalina tamponada a 10\% (Figura 21A e 21B). Para a análise molecular, foi feita uma biópsia com trefina $(5 \mathrm{~mm})$ na região de ambos os seios maxilares e colocadas imediatamente no reagente RNAlater (Figura 22A e 22B). Cuidados adicionais foram tidos com as peças para que não houvesse contaminação nenhuma entre o material genético das mesmas. Foram congeladas num freezer a $-80^{\circ}$ Celsius, no Centro Integrado em Pesquisas da FOB/USP (CIP). 


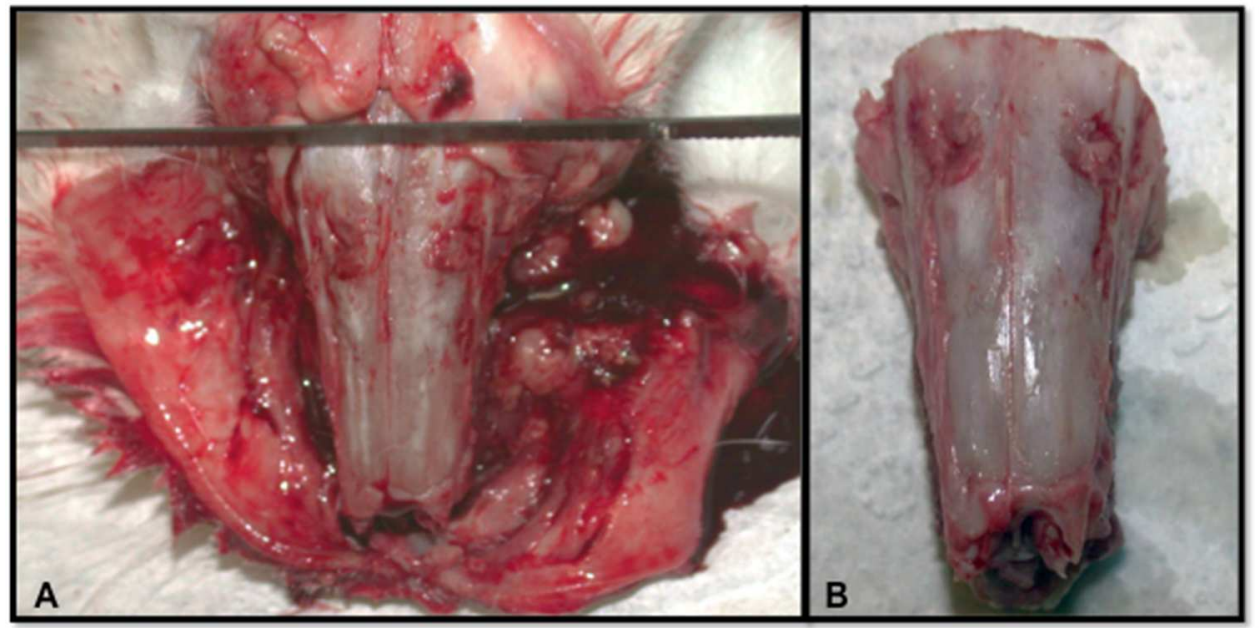

Figura 21 - A. Imagem da maxila do coelho removida para análise microscópica e B. a peça dissecada

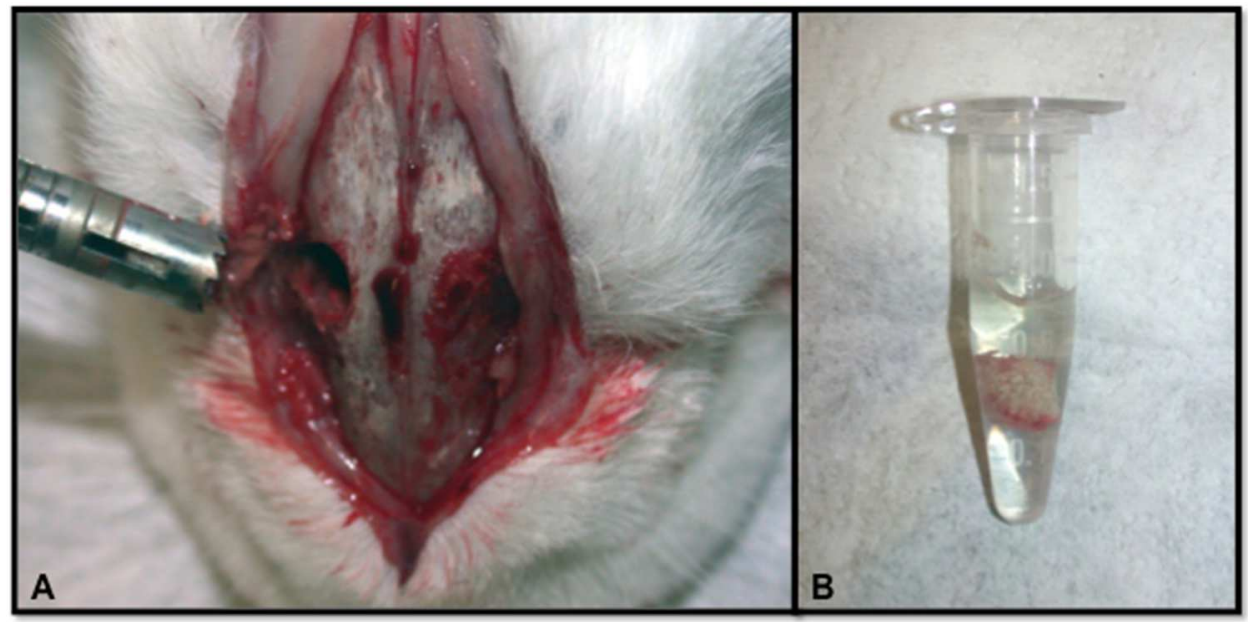

Figura 22 - A. Imagem da coleta do espécime para análise molecular e B. a amostra no eppendorf

\subsection{ANÁLISE DOS RESULTADOS}

\subsubsection{Análise através de tomografias computadorizadas por feixe cônico (TCFC)}

Os espécimes da análise microscópica foram tomografados no tomógrafo computadorizado por feixe cônico, utilizando-se um aparelho i-CAT® (Imaging Sciences International, Pensivânia, EUA) do Departamento de Estomatologia, da Faculdade de Odontologia de Bauru, Universidade de São Paulo, com o objetivo inicial de uma análise geral do seio maxilar experimental, confirmação do material no seu interior e anotações de qualquer observação digna de nota. Foi adotado, para as tomografias, o protocolo de 18,45mAs (Max 6cm, 20Sec, 0,3 voxel). As imagens foram analisadas nas reconstruções axial, coronal e sagital e foram observados 2 seios maxilares por animal (Figura 23). 



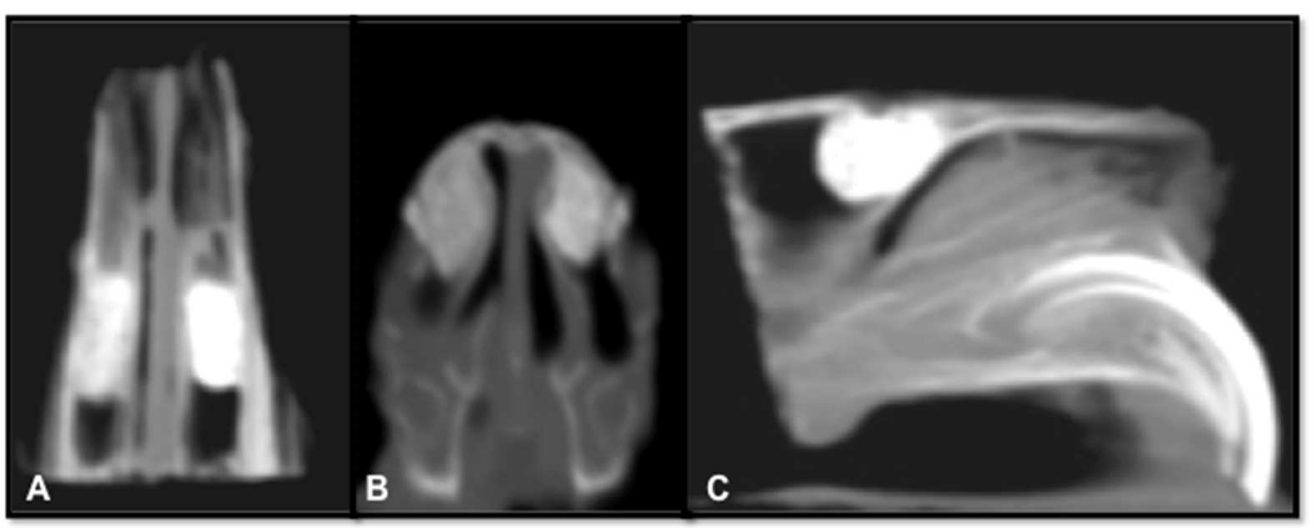

Figura 23 - A. Reconstruções axial, B. coronal e C. sagital de uma maxila

A análise das TCFC foi feita qualitativamente e foram avaliadas a presença ou ausência do material no interior do seio maxilar, presença ou ausência de velamento no interior da cavidade e no seio inferior e disposição difusa ou circunscrita do implante. Além disso, anotou-se qualquer alteração significante que pudesse estar presente.

\subsubsection{Análise microtomográfica}

\subsubsection{Obtenção dos exames}

As amostras fixadas em formol 10\% (106 espécimes) foram submetidas a exame de microtomografia computadorizada (MicroTC) (MicroCT40, Scanco Medical, Basserdorf, Suíça), no Institute of Biomaterials and Biomedical Engineering, University of Toronto, (Figura 24) com a finalidade de avaliar com maior resolução a área submetida ao levantamento de seio maxilar. Para obter a maior resolução, previamente ao escaneamento, foi feita a macroscopia das peças cuidadosamente para a individualização de cada seio maxilar (Figura 25). Três espécimes por vez foram escaneados contidos num recipiente cilíndrico de polimetilmetacrilato (PMMA) contendo formalina $10 \%$ seguindo o mesmo protocolo: 55Kvp; alta resolução; FOV/diameter: 16.4; BH: 1200mgHA/ccm; Scaling:4096. Os espécimes foram escaneados sempre posicionados com a porção anterior do seio maxilar voltada para cima e entre cada espécime foi colocada uma esponja específica para o suporte e separação dos mesmos. O tempo de escaneamento e digitalização de cada espécime foi aproximadamente 3 horas e meia. 



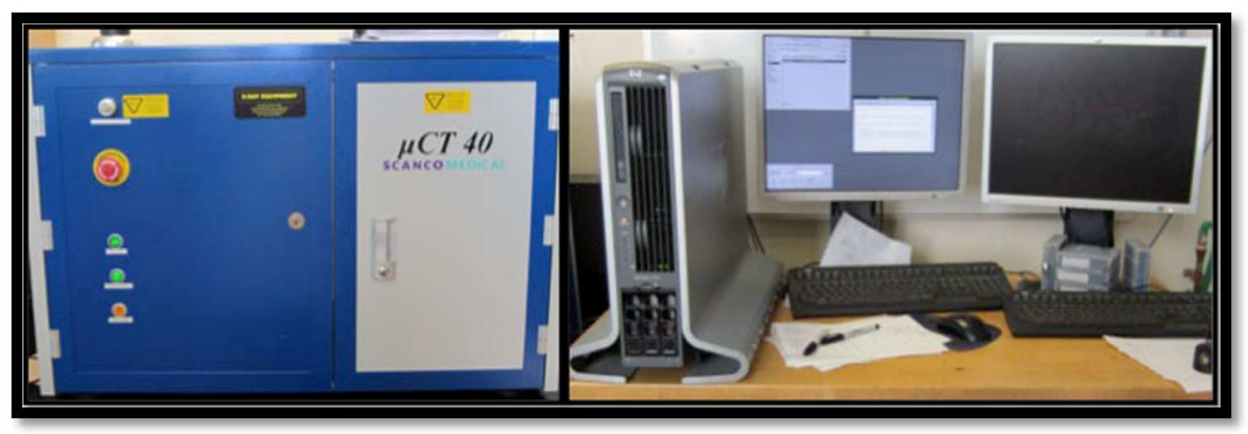

Figura 24 - MicroCT (MicroCT40, Scanco Medical, Basserdorf, Suíça)

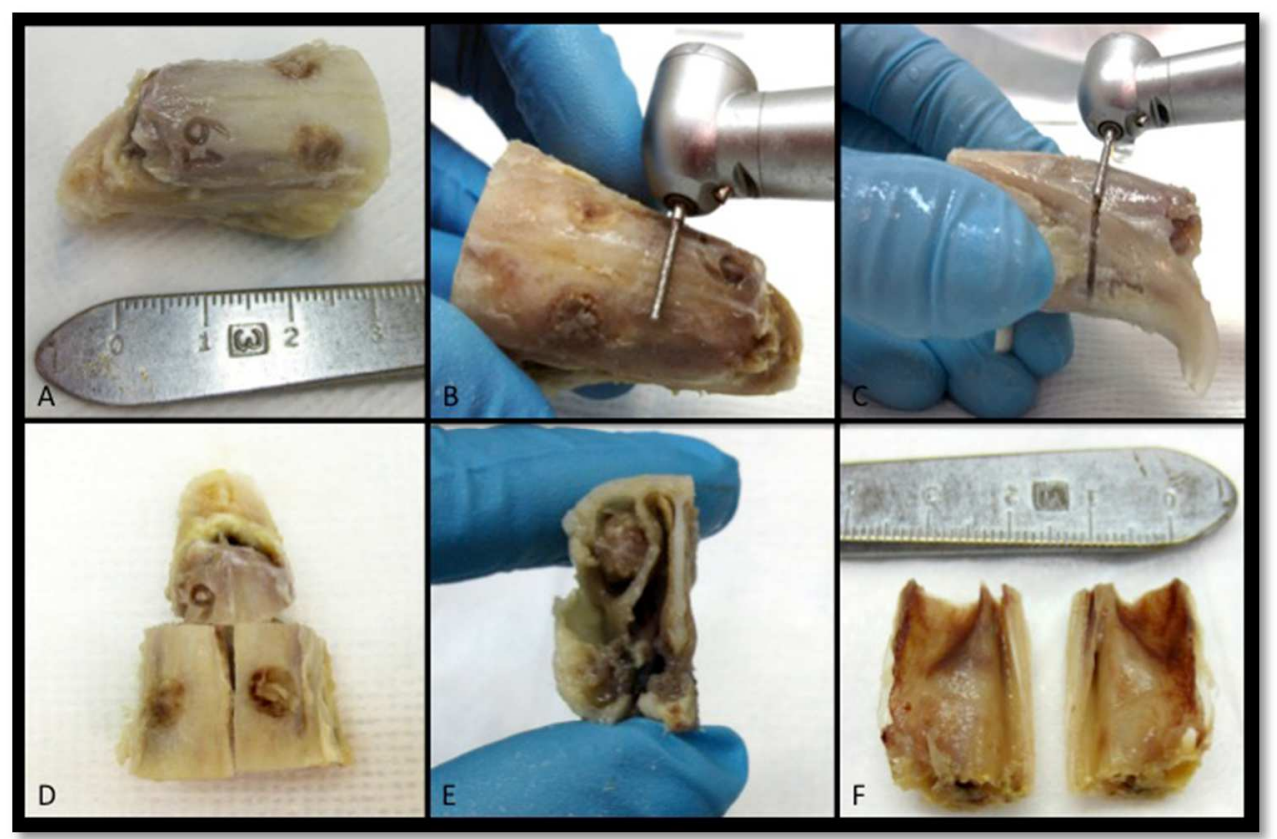

Figura 25 - Macroscopia dos espécimes. A. Maxila fixada em formalina 10\%. B,C. Osteotomia com ponta diamantada 4138 para a fragmentação da peça. D. Maxila dividida em 3 segmentos. E. Visão posterior de hemimaxila esquerda e conteúdo no interior do seio maxilar compatível com o enxerto. F. Visão interna dos seios maxilares individualizados 



\subsubsection{Avaliação dos exames}

\subsection{Análise Qualitativa}

Através do software de avaliação do aparelho (MicroCT evaluation program V 6.0), a imagem de cada espécime foi reformatada e avaliada na reconstrução coronal (Figura 26). A primeira avaliação foi qualitativa, principalmente para a avaliação da presença de tecido ósseo no interior da área do enxerto e em contato com o material nos diferentes tempos. Além disso, observou-se se havia suspeita de perda do material diante de perfuração e foram realizadas outras observações quando houvesse algo digno de nota. Após a análise de uma sequência de reconstruções bidimensionais de cada espécime, foram capturadas 5 das mais representativas da área total de um espécime, por grupo, com finalidade ilustrativa e de comparação entre o comportamento dos materiais em cada período (Figura 27). Essa comparação foi feita observando se houve diferença entre o volume total de cada preenchimento com o tempo e a quantidade de tecido ósseo entre os substitutos ósseos em cada espécime.

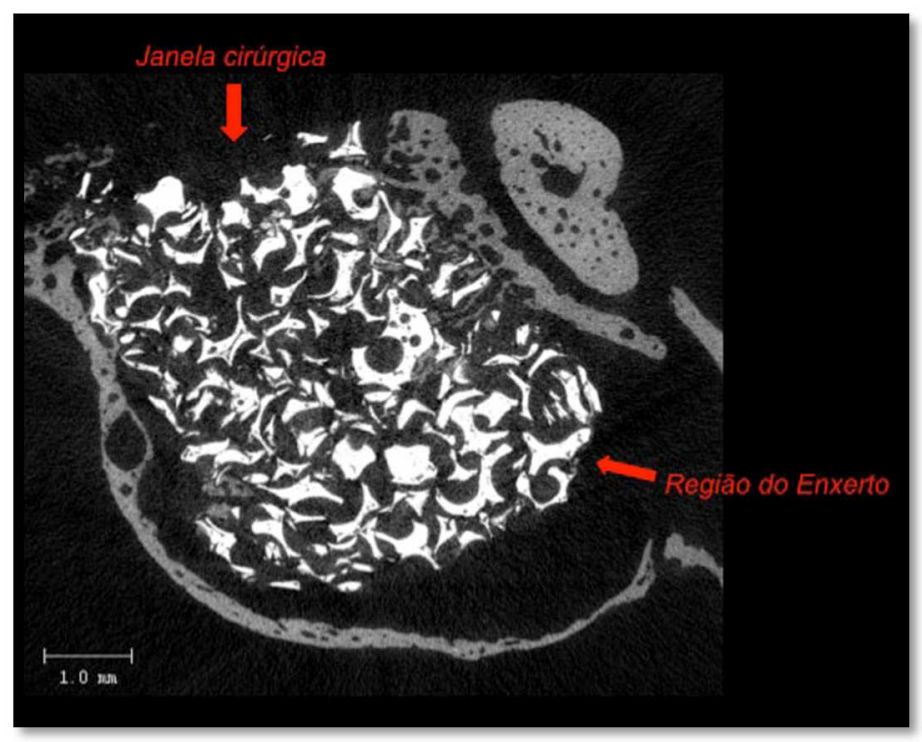

Figura 26 - Reconstrução coronal do seio maxilar 



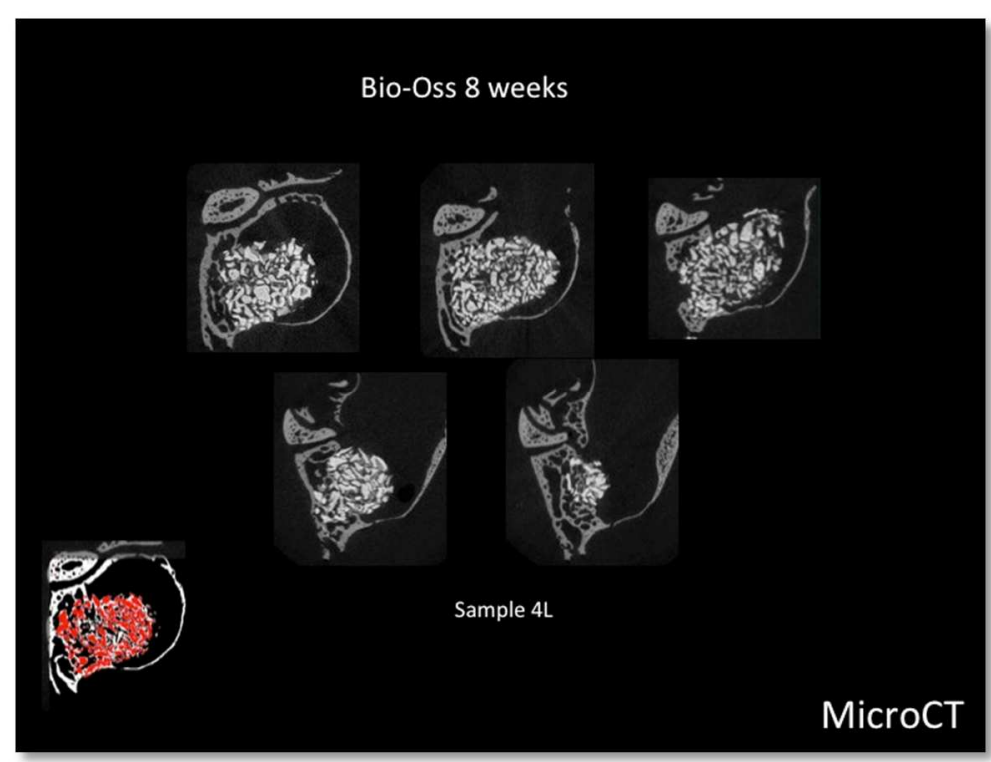

Figura 27 - Seleção de cortes mais representativos de diferentes áreas, da mesma amostra, para análise qualitativa

\subsection{Análise Quantitativa}

Análise histomorfométrica foi feita nas reconstruções dos espécimes utilizando o mesmo software descrito acima. Foram selecionados 72 espécimes $(n=6)$, utilizando como critério de escolha, os espécimes que não sofreram perfurações. $\mathrm{O}$ volume total da área de enxerto foi delimitado através de um desenho realizado na reconstrução coronal do espécime, utilizando as ferramentas do programa (Figura 28). 500 "slices" ou reconstruções coronais na região da janela cirúrgica de cada espécime foram delimitados através de um desenho circundando o volume total e incluídos na quantificação (Figura 29). Previamente à quantificação, foi preciso definir um contraste, ajustando a escala de cinzas de modo que cada material fosse distinguido do tecido ósseo neoformado. Foram calculados volume total (VT), volume ósseo (VO), relação entre volume ósseo e volume total (VO/VT), número de trabéculas (NT), espessura das trabéculas (ET) e separação entre as trabéculas (ST) (Figura 30). 



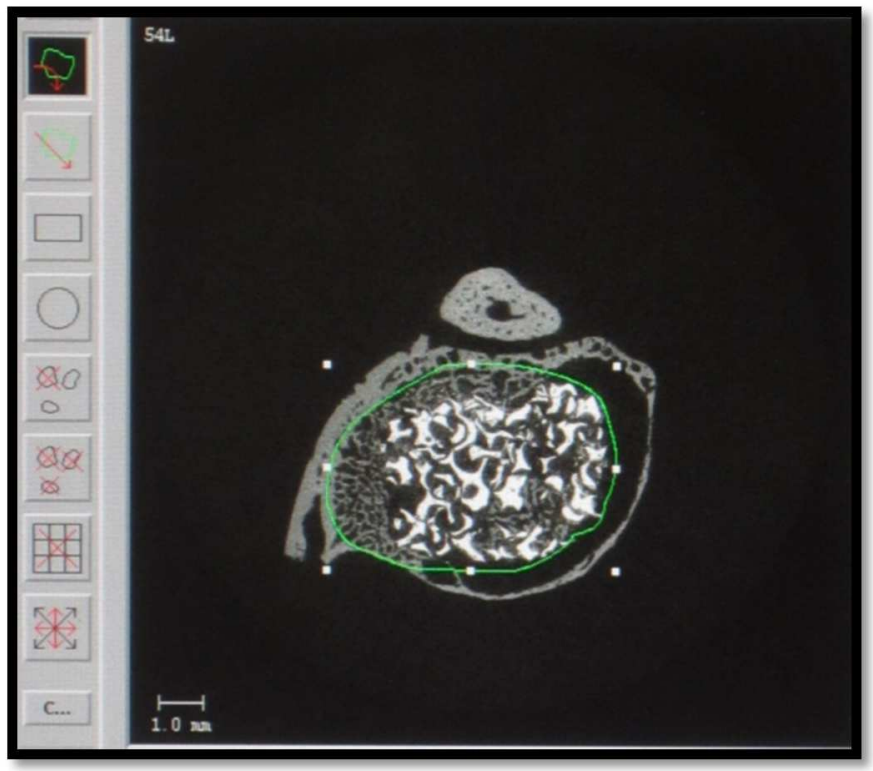

Figura 28 - Desenho do volume total realizado com a ferramenta do programa

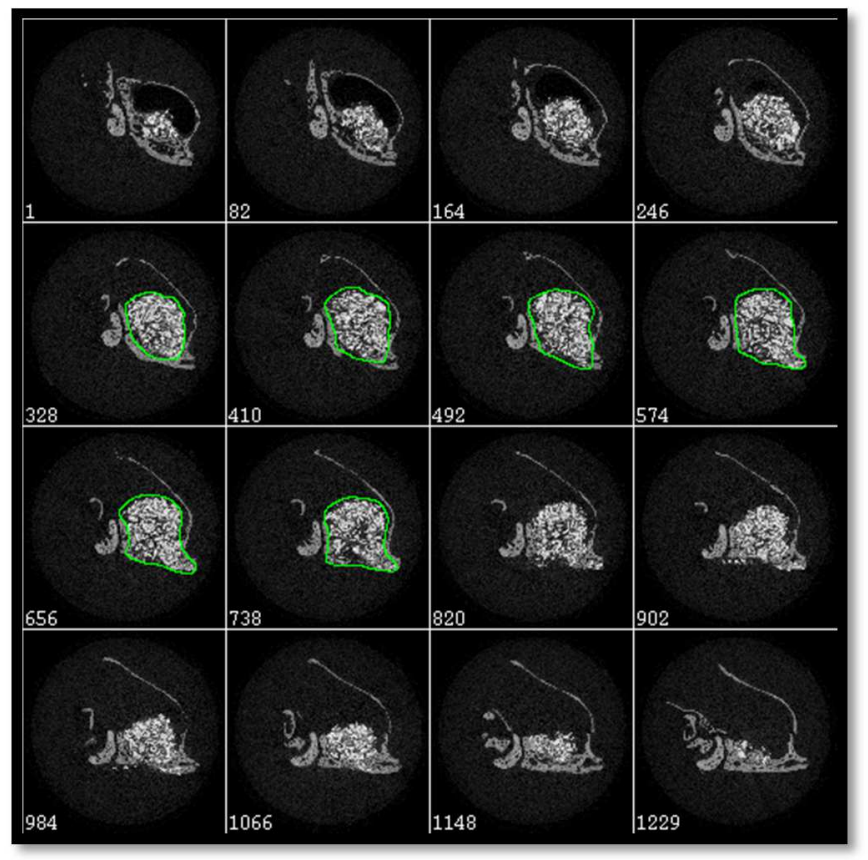

Figura 29 - Faixa de reconstruções coronais selecionadas para serem desenhadas e analisadas 



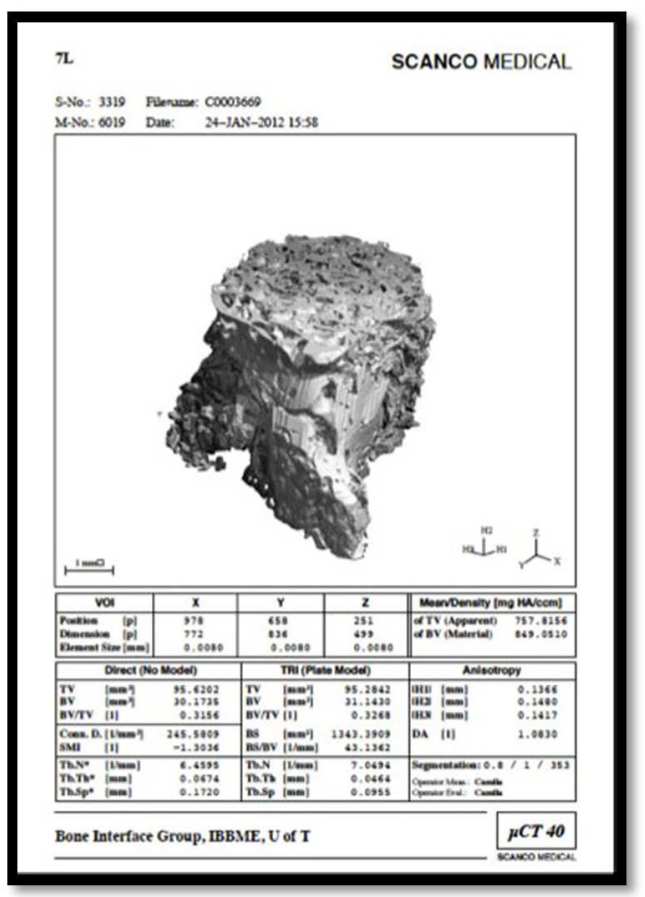

Figura 30 - Imagem dos resultados impressos, após a quantificação histomorfométrica, calculada pelo programa

\subsection{Análises microscópicas qualitativas}

\subsubsection{Desidratação e inclusão das amostras em resina}

Após serem escaneadas pelo MicroCT, as amostras foram submetidas ao procedimento de inclusão em resina (Osteo-Bed Bone Embedding Resin ${ }^{\mathrm{TM}}$ ) para as análises microscópicas. Todo procedimento laboratorial foi realizado no Institute of Biomaterials and Biomedical Engineering, University of Toronto. O processo de inclusão se iniciou com a lavagem das amostras em água corrente por meia hora e, após, duas lavagens em água destilada. Em seguida, as amostras foram desidratadas em soluções alcoólicas em temperatura ambiente com concentrações graduais crescentes (etanol 70, 95 e 100\% v/v). A cada dois dias, a mesma solução foi substituída e a cada 4 dias se trocava a concentração. Após a desidratação, iniciou-se o processo de infiltração da resina nos espécimes em frascos de vidro. Inicialmente, a amostra ficou embebida apenas no monômero Osteo-Bed ${ }^{\mathrm{TM}} \mathrm{I}$ em temperatura ambiente, sob vácuo, durante seis dias, com uma substituição no terceiro dia. Na sequência, Osteo-Bed ${ }^{\mathrm{TM}}$ II $(1,4 \mathrm{~g}$ de de peróxido de benzoil - catalisador, em 100ml de monômero) foi utilizado sob vácuo e refrigerado a $4^{\circ} \mathrm{C}$, durante seis dias, com uma troca no terceiro dia. Após a infiltração gradual da resina, as amostras foram incluídas em Osteo-Bed ${ }^{\mathrm{TM}}$ III $(3,5 \mathrm{~g}$ de 
peróxido de benzoil - catalisador, em 100ml de monômero) em novos frascos de vidro com uma base de $2 \mathrm{~mm}$ da mesma resina polimerizada previamente. Imediatamente após a inclusão, as amostras foram submetidas a vácuo, em temperatura ambiente durante um dia. No dia seguinte, foram colocadas em um forno com temperatura de $35^{\circ} \mathrm{C}$ durante 5 dias e, em seguida, a temperatura foi aumentada para $50^{\circ} \mathrm{C}$ até completar a polimerização. Após a polimerização, a temperatura foi aumentada para $60^{\circ} \mathrm{C}$ durante um dia e, após seu resfriamento, os frascos foram quebrados com um martelo.

\subsubsection{Preparo das lâminas}

Os blocos de resina foram cortados e polidos com equipamentos do sistema Exakt Band System 300 e Exakt 400 CS (EXAKT technologies, Inc., Oklahoma, EUA), respectivamente (Figura 31, 32). Para essa etapa, inicialmente, os blocos de resina contendo o espécime inteiro foram colados a uma lâmina mais espessa do tipo back-up. Na sequência, o bloco foi cortado na região média da janela cirúrgica no sentido coronal, semelhante ao plano de análise no MicroCT. O bloco livre da lâmina foi devidamente polido e utilizado para análise de microscopia eletrônica de varredura por retroespalhamento de elétrons (SEM). O conjunto formado por lâmina back-up e bloco de resina cortado ao meio foi colado a uma lâmina final mais fina, para ser desgastado, com finalidade de outras análises microscópicas. Os blocos de resina foram cortados em fatias (aderida à lâmina final) de, aproximadamente, 250 $\mu \mathrm{m}$, no dispositivo Exakt 300 (Figura 33) e, depois, cada fatia foi desgastada e polida no dispositivo Exakt 400 CS (Figura 34), utilizando-se lixas de granulação gradativamente mais finas $(800,1000,1200,2400$ e 4000). 


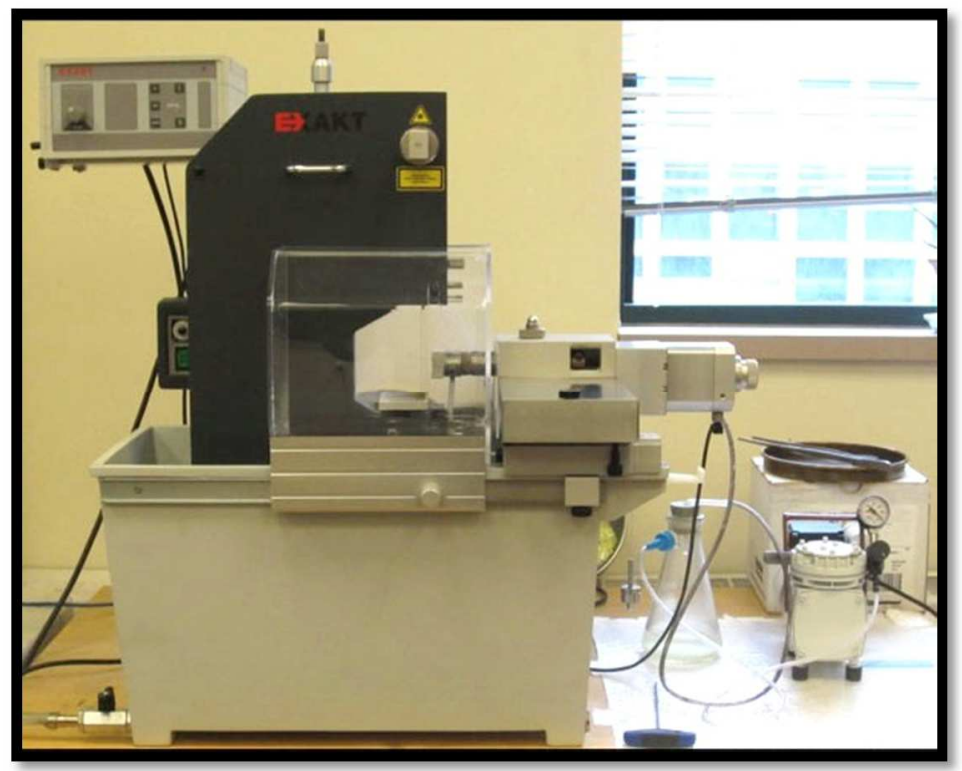

Figura 31 - Equipamento Exakt 300 utilizado para o corte dos blocos e confecção das lâminas finais

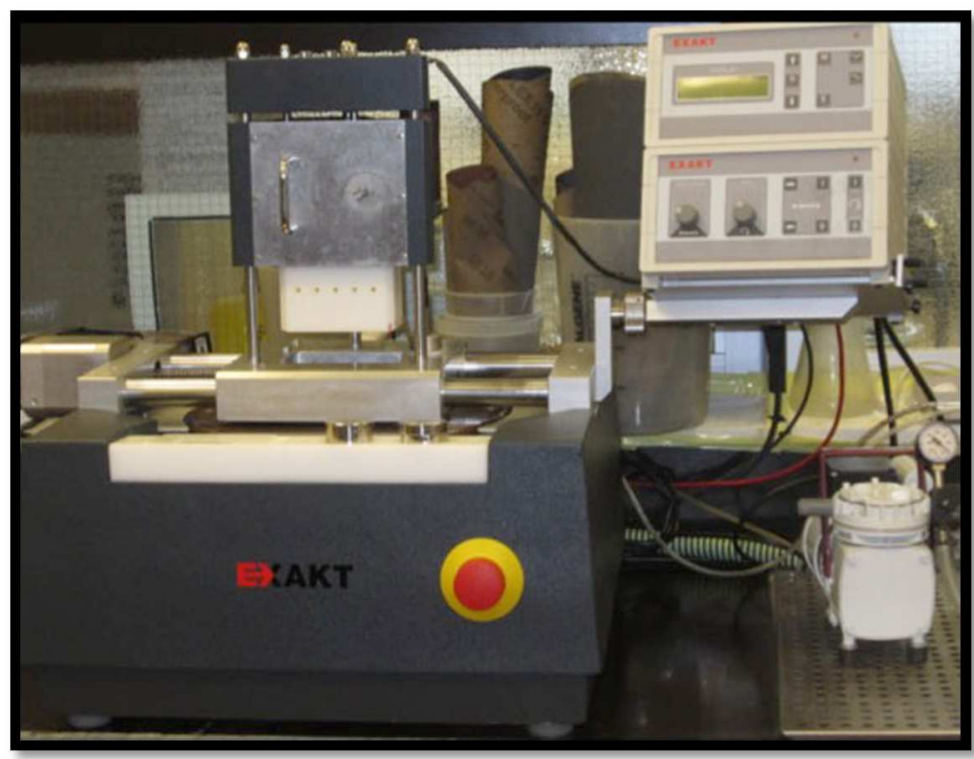

Figura 32 - Equipamento Exakt 400 CS utilizado para o desgaste e polimento das lâminas finais

O dispositivo Exakt 400 CS (EXAKT technologies, Inc., Oklahoma, EUA) permite um desgaste programado, baseado na espessura final desejada, utilizando para cada espessura de corte uma granulação de lixa, considerando a quantidade de desgaste desejada. A partir da espessura de $30 \mu \mathrm{m}$, foi utilizado um protocolo de desgaste baseado no tempo. A cada 5 minutos de desgaste, utilizando-se a lixa mais fina (4000), a espessura da lâmina era conferida até o corte atingir a espessura próxima a $15 \mu \mathrm{m}$. 
As lâminas finais correspondentes aos espécimes marcados com fluorocromos foram submetidas à análise quantitativa com microscópio confocal, e as restantes foram utilizadas para análise microscópica qualitativa após coloração com azul de toluidina e hematoxilinaeosina.

\subsubsection{Microscopia eletrônica de varredura}

A microscopia eletrônica de varredura (SEM) por retroespalhamento de elétrons foi realizada para a análise minuciosa da interface entre o substituto ósseo e o osso neoformado em cada período. Também foi realizada no Institute of Biomaterials and Biomedical Engineering, University of Toronto.

Os blocos de resina, após serem devidamente polidos, foram avaliados em microscópio eletrônico de varredura, modelo Hitachi VP-SEM 3400N (Hitachi HighTechnologies Europe GmbH, Germany) (Figura 33). A sequência da captura da imagem se encontra ilustrada na figura 37.

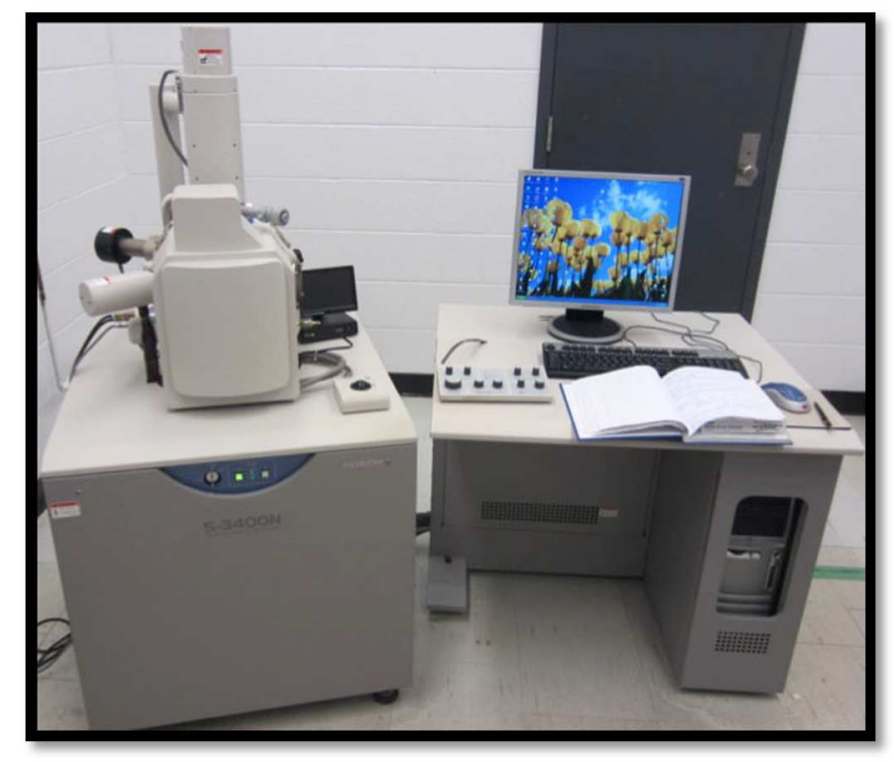

Figura 33 - Microscópio eletrônico de varredura, modelo Hitachi VP-SEM 3400N 


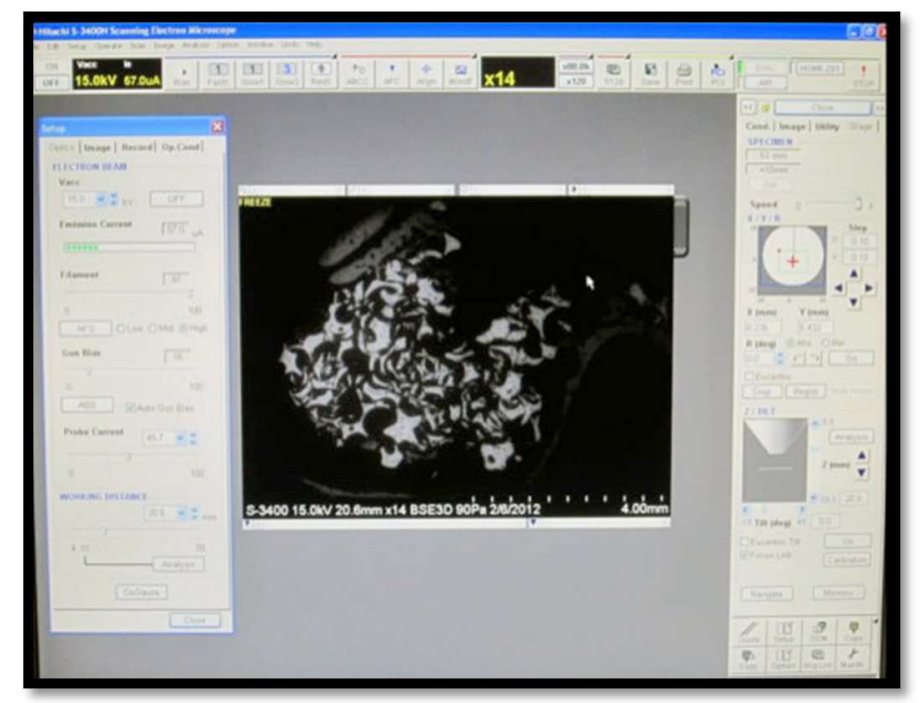

Figura 34 - Ilustração da captura da imagem no microscópio eletrônico de varredura

\subsubsection{Análise qualitativa em microscópio óptico}

As lâminas preparadas no sistema Exakt, após devidamente polidas, foram submetidas a dois tipos de coloração para análise microscópica qualitativa em microscópio óptico [Aristoplan (Leitz, Wetzlar, Alemanha)]: azul de toluidina e hematoxilina-eosina. Foram observadas principalmente, a integridade da membrana sinusal, a presença de osteocondução representada pela neoformação óssea circundando o biomaterial e ainda a distribuição da neoformação óssea na área do enxerto (janela cirúrgica, na região central e próximo a membrana), presença de infiltrado inflamatório e células gigantes multinucleadas em contato ao biomaterial e a capacidade de biodegradação.

\subsubsection{Coloração com azul de toluidina (AT)}

As lâminas selecionadas para coloração com azul de toluidina não receberam nenhum tipo de tratamento de superfície. A coloração foi feita individualmente e duas gotas da solução foram depositadas na área central do espécime e deixadas por 8 minutos num forno em temperatura de $35^{\circ} \mathrm{C}$. Em seguida foram lavadas em água corrente. Se a intensidade da coloração se apresentasse fraca, o procedimento era repetido, porém observado a cada 3 minutos. 


\subsubsection{Coloração com hematoxilina-eosina (HE)}

O protocolo para coloração em HE de espécimes embebidos em resina seguiu o protocolo convencional para parafina, porém modificando-se o tempo de imersão em hematoxilina para 1 hora e em eosina para 10 minutos. A montagem final da lâmina com a lamínula foi com uma gota de água, no momento do estudo no microscópio óptico.

\subsubsection{Análise quantitativa através de microscopia confocal}

Os 36 espécimes $(n=3)$ marcados com fluorocromos na fase experimental foram analisados em microscópio confocal Leica TSS SPE (Mannheim Alemanha) no Centro Integrado de Pesquisa (CIP) da FOB/USP, com o objetivo de observar a quantidade de neoformação óssea nos diferentes períodos. As lâminas utilizadas na análise apresentaram espécimes com espessura média de $15 \mu \mathrm{m}$. Foram selecionados 3 campos distintos do espécime: região mais próxima à janela cirúrgica (Campo 1), região central (Campo 2) e periferia do enxerto próxima à membrana sinusal (Campo 3), as quais foram analisadas com objetiva ACS APO 10X/0.30 CS, espessura de análise em torno de $20 \mu \mathrm{m}$, com seccionamento óptico a cada $2 \mu \mathrm{m}$, sempre numa posição padronizada para todos os espécimes. Utilizou-se para a análise, as marcações com tetraciclina, alizarina e calceína com faixas espectrais: $405 \mathrm{~nm}, 532 \mathrm{~nm}$, e $488 \mathrm{~nm}$ respectivamente. O detector espectral foi programado para captar a emissão nas faixas de 550 a 605nm (tetraciclina), 595 a 700nm (alizarina) e de 490 a 544nm (calceína).

Após a obtenção das 3 imagens por espécime, a análise histomorfométrica da marcação de neoformação óssea foi realizada através do software AxionVision 40V 4.82.0 (Carl Zeiss MicroImaging $\mathrm{GmbH}$ ). O resultado foi expresso em porcentagem do marcador ósseo (Figura 35). 


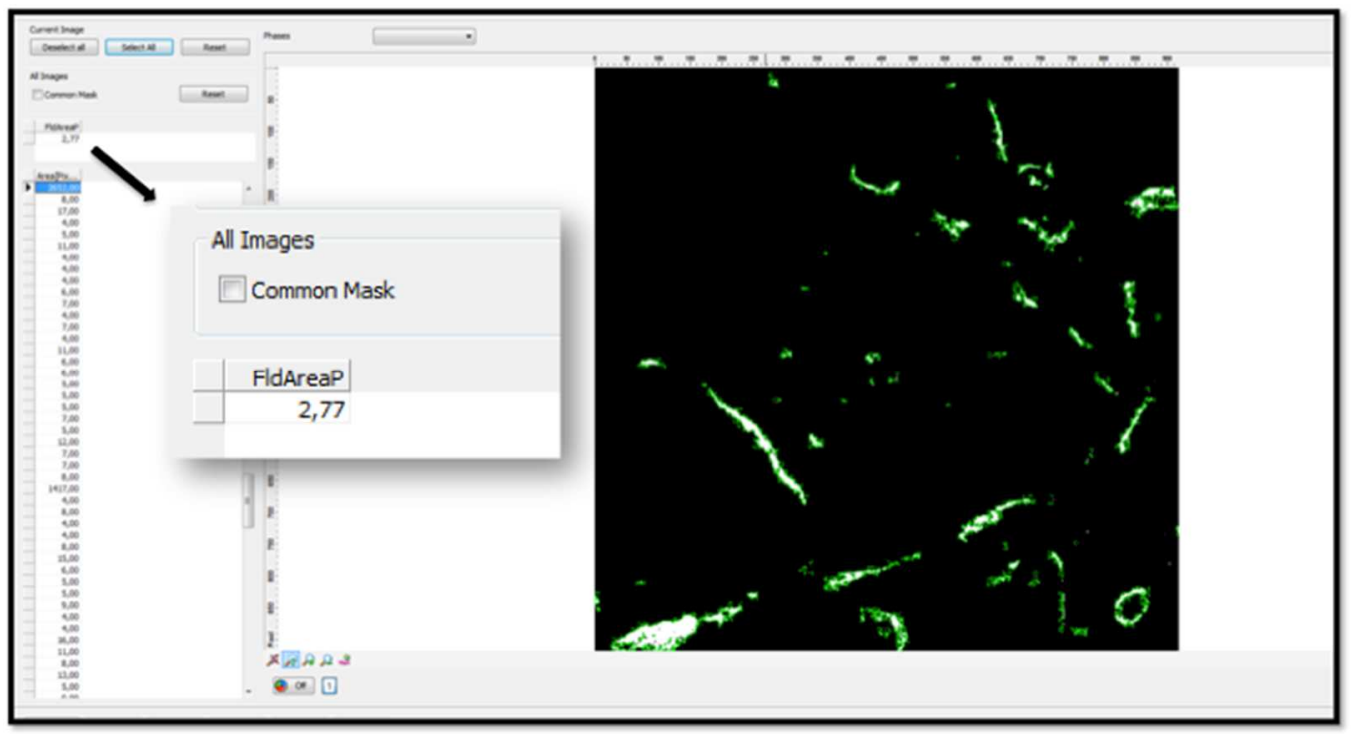

Figura 35 - Imagem ilustrativa da quantificação do marcador ósseo calceína (em verde), em porcentagem, pelo software AxionVision 40V 4.82.0 (Carl Zeiss MicroImaging GmbH)

\subsection{Análise molecular}

Algumas amostras foram submetidas à análise molecular após um período de congelamento a $-80^{\circ}$ Celsius no Centro Integrado de Pesquisa CIP/FOB. O estudo foi realizado no Departamento de Histologia da FOB/USP, sob orientação do Prof. Dr. Gustavo P. Garlet. Alguns marcadores de remodelação óssea foram selecionados para serem analisados pela técnica de RealTimePCR após extrações de RNA e transcrição reversa dos espécimes.

Os marcadores avaliados foram: 1. COL1A1: Colágeno tipo-1 alfa-1, VEGF-A: fator de crescimento endotelial vascular-A (estimula a proliferação e crescimento de vasos sanguíneos), RUNX2: Runt related transcription fator 2 (responsável pelo estímulo da diferenciação de células precursoras em osteoblastos); BMP2: Proteína óssea morfogenética 2 (importante na sinalização da formação óssea); SPARC: Osteonectina ou Secreted protein, acid, cysteine-rich (secretada pelos osteoblastos e atua na mineralização); ALPL: Fosfatase alcalina (marcador de formação óssea relacionada à mineralização óssea.).

Abaixo se encontra a tabela 1, representativa da quantidade de animais por grupo e o marcador avaliado. O número de espécimes variou entre os grupos em decorrência das perdas. 
Tabela 1 - Quantidade de espécimes por grupo e período submetidas a quantificação dos 6 marcadores descritos abaixo

\begin{tabular}{cccccc}
\hline Período & OsteoScaf $^{\mathrm{IM}}$ & Bio-Oss $®^{\circledR}$ & BoneCeramic $®$ & Autógeno \\
\hline 8 & $\mathbf{3}$ & $\mathbf{2}$ & $\mathbf{2}$ & $\mathbf{1}$ \\
4 & $\mathbf{2}$ & $\mathbf{2}$ & $\mathbf{1}$ & $\mathbf{1}$ \\
2 & $\mathbf{3}$ & $\mathbf{2}$ & $\mathbf{2}$ & $\mathbf{1}$ \\
Total & $\mathbf{8}$ & $\mathbf{6}$ & $\mathbf{5}$ & $\mathbf{3}$ \\
\hline
\end{tabular}

\subsubsection{Extração de RNA e Transcrição Reversa}

Para a extração do RNA, os tubos contendo os seios maxilares já triturados foram incubados por 5 minutos a $4^{\circ} \mathrm{C}$ e, então, foi adicionado um volume de $20 \%$ de clorofórmio. Os tubos foram vigorosamente agitados e deixados em repouso a $4{ }^{\circ} \mathrm{C}$ por 5 minutos, sendo em seguida centrifugados a 12.000 g por 25 minutos. A camada superior (fase aquosa) foi recuperada em alíquotas de $400 \mu \mathrm{L}$, que foram colocadas em tubos de microcentrífuga de 1,5 $\mathrm{ml}$ contendo $400 \mu \mathrm{L}$ de isopropanol. Os tubos foram agitados vigorosamente e deixados em repouso a $4^{\circ} \mathrm{C}$ por 15 minutos. Após centrifugação a 15.000 g por 20 minutos a $4{ }^{\circ} \mathrm{C}$, o precipitado de RNA foi obtido e, em seguida, o sobrenadante foi descartado e ao precipitado adicionado $1 \mathrm{~mL}$ de etanol $70 \%$ em água com dietil pirocarbonato 0,1\% (DEPC), agitando-se vigorosamente. Foi realizada nova centrifugação a 15.000 g por 10 minutos a $4{ }^{\circ} \mathrm{C}$, descartando-se o sobrenadante e repetindo-se outra centrifugação com $1 \mathrm{ml}$ de etanol 70\% a $15.000 \mathrm{~g}$ por 10 minutos a $4^{\circ} \mathrm{C}$. Para permitir a secagem das amostras, o sobrenadante foi descartado e os tubos foram deixados abertos em temperatura ambiente por 5 minutos dentro de uma capela de fluxo laminar vertical (para impedir a contaminação das amostras). Para redissolver o RNA total, os tubos de microcentrífuga receberam um volume de $50 \mu \mathrm{L}$ de água tratada com DEPC $0,1 \%$ e foram incubados a $65^{\circ} \mathrm{C}$ por 15 a 30 minutos, até a dissolução dos precipitados.

\subsubsection{Quantificação do RNA total}

A concentração de RNA total nas amostras foi determinada por diluição do RNA (fator de diluição conhecido) e leitura em cubetas de quartzo em espectrofotômetro Pharmacia (Ultrospec 2000) no comprimento de onda de $260 \mathrm{~nm}$ (A260). A fórmula para calcular a 
concentração de RNA total foi a seguinte: $($ RNA) = A260 x 40 x fator de diluição conhecido, sendo o resultado expresso em $\mathrm{mg} / \mathrm{ml}$. A qualidade do RNA total nas amostras foi determinada pela diluição do RNA (em Tris-HCl 10 mM, pH 7,8) e leitura da absorbância em cubetas de quartzo em espectrofotômetro nos comprimentos de onda de 260 e $280 \mathrm{~nm}$ (A260 e A280). Foi calculada a relação A260/A280, a qual foi considerada aceitável entre 1,9 e 2,1, pois valores nesse intervalo indicam ausência de DNA na amostra.

\subsubsection{Transcrição do RNA em cDNA}

Foram utilizados $5 \mu \mathrm{g}$ de RNA total para a transcrição em DNA complementar (cDNA) por meio da enzima transcriptase reversa (Kit de transcrição reversa - Superscript III, Invitrogen). Aos tubos contendo o RNA foi adicionado $0,2 \mu \mathrm{g}$ de hexadeoxinucleotídeos (dNTPs) e $1 \mu \mathrm{l}$ de Oligo dT primer (invitrogen), sendo essa mistura incubada a $65^{\circ} \mathrm{C}$ por 5 minutos. Após a incubação, foi colocado no tubo: $1 \mu$ l da enzima transcriptase reversa e $4 \mu 1$ do Tampão e incubado novamente a $50^{\circ} \mathrm{C}$ por 1 hora, seguida de outra incubação a $70^{\circ} \mathrm{C}$ por 15 minutos.

\subsubsection{Reações de RealTimePCR}

A quantificação da expressão de mRNA (RNA mensageiro) codificando genes de fatores integrantes da remodelação óssea (COL1A1, VEGF, RUNX2, BMP2, SPARC e ALPL) foi realizada através de reações de RealTimePCR, utilizando-se o sistema SYBRGreen em um aparelho MiniOpticon (BioRad). Pares de primers adequados para cada uma das reações de amplificação foram criados a partir de sequências de mRNA para os genes alvo, utilizando-se o programa Primer Express (Applied Biosystems).

Para todas as reações de RealTimePCR, foram utilizados $13 \mu 1$ do reagente SYBRGreen Master Mix (Invitrogen - que contém o fluoróforo SYBRGreen), $5 \mu 1$ da solução de cDNA (sintetizado como previamente descrito), $6 \mu 1$ de água MiliQ tratada com DEPC, e $1 \mu \mathrm{l}$ da solução contendo o par de primer (concentração final igual a 0,2uM). Previamente, as reações de RealTimePCR foram otimizadas com relação às concentrações ideais de cada par de primers e temperatura de annealing, de modo a maximizar eficiência e a especificidade de amplificação.

Os resultados foram analisados com base no valor de CT (cicle threshold - ou ciclo limiar), sendo este o ponto correspondente ao número de ciclos em que a amplificação atinge 
um dado limiar durante a fase de amplificação exponencial da PCR, que permite a análise quantitativa da expressão do fator avaliado em relação ao nível de expressão de um gene constitutivo. Para as reações de RealTimePCR, foram utilizadas, independentemente, amostras de cDNA provenientes do RNA extraído do levantamento de seio maxilar de, no máximo, 3 animais de cada grupo (Tabela 1), coletados de acordo com os tempos experimentais (2, 4 e 8 semanas após o procedimento). Os resultados apresentados representaram os valores da média $\pm \mathrm{SD}$, da intensidade de expressão de mRNA para o gene alvo, normalizado pela expressão da beta-actina, obtidos de alguns animais de cada período experimental. As reações de RealTimePCR foram realizadas no Laboratório de Biologia Molecular, da disciplina de Histologia, do Departamento de Ciências Biológicas da FOB/USP (equipamentos financiados pela FAPESP, projeto 2006/00534-1), sob orientação do Prof. Dr. Gustavo P. Garlet.

\subsection{Análise estatística}

As análises estatísticas foram realizadas sob orientação do Prof. Dr. José Roberto Lauris Pereira, do Departamento de Saúde Coletiva da FOB-USP. Os resultados quantitativos da histomorfometria pelo MicroCT foram submetidos à análise estatística de variância (ANOVA) a 2 critérios e teste de Tukey. Foi adotado nível de significância de 5\% (p<0,05). Para a análise quantitativa das imagens obtidas no microscópio confocal foi realizado teste Anova a 3 critérios e Teste de Tukey para as variáveis tetraciclina e alizarina e teste Anova a 2 critérios e Teste de Tukey para a calceína. A análise molecular somente foi descrita qualitativamente em decorrência do número pequeno de amostra por grupo e período. 


\section{REsUltados}





\section{RESULTADOS}

\subsection{Achados clínicos}

Quatro animais morreram entre o segundo e o terceiro dia pós-operatório e as razões foram desconhecidas. Houve a reposição de dois animais, os quais apresentaram boa recuperação e não houve nenhum sinal clínico de infecção durante o período pós-operatório.

\subsection{Análise das tomografias computadorizadas por feixe cônico (TCFC)}

Os resultados das TCFC foram descritos na Tabela 2. Diante da existência de perfuração da membrana, em algumas amostras, durante o procedimento cirúrgico, procurouse correlacioná-las com os achados analisados na TCFC.

Tabela 2 - Resultados da análise qualitativa realizada nas TCFC

\begin{tabular}{lccc}
\hline Presença do biomaterial & $\mathbf{1 0 6}$ & $\mathbf{1 0 0 \%}$ & $\begin{array}{c}\text { Perfurações da } \\
\text { membrana }\end{array}$ \\
\hline Aspecto circunscrito do biomaterial & 103 & $97.17 \%$ & 3 \\
Aspecto difuso do biomaterial & 3 & $2.83 \%$ & 2 \\
$\begin{array}{l}\text { Velamento no seio experimental e nos } \\
\text { inferiores }\end{array}$ & 19 & $17.92 \%$ & 4 \\
$\begin{array}{l}\text { Velamento somente nos seios maxilares } \\
\text { inferiores }\end{array}$ & 8 & $7.55 \%$ & - \\
\hline
\end{tabular}

\subsection{Análise microtomográfica}

\subsubsection{Análise qualitativa}

A análise qualitativa compreendeu uma minuciosa observação de cada sequência de reconstruções bidimensionais, por espécime, sendo possível observar qualitativamente o comportamento de cada grupo, por período. Após a análise do exame completo de cada espécime, uma sequência de 5 "slices" ou reconstruções bidimensionais microtomográficas mais representativas, de cada espécime, foram capturados para comparação. Exemplo desta sequência selecionada, em cada grupo, por período, foi ilustrado na Figura 36. 

Para a descrição dos resultados, os grupos foram abreviados da seguinte forma: OsteoScaf $^{\mathrm{TM}}$ (BoneTec Corp - TRT, Toronto, Canadá) (OS), Bio-Oss ${ }^{\circledR}$ (Geistlich Biomaterials, Wolhusen, CH, Suíça) (BI), BoneCeramic ${ }^{\circledR}$ (Instituto Straumann AG, Basel, Suíça) (BO) e osso autógeno (AU).
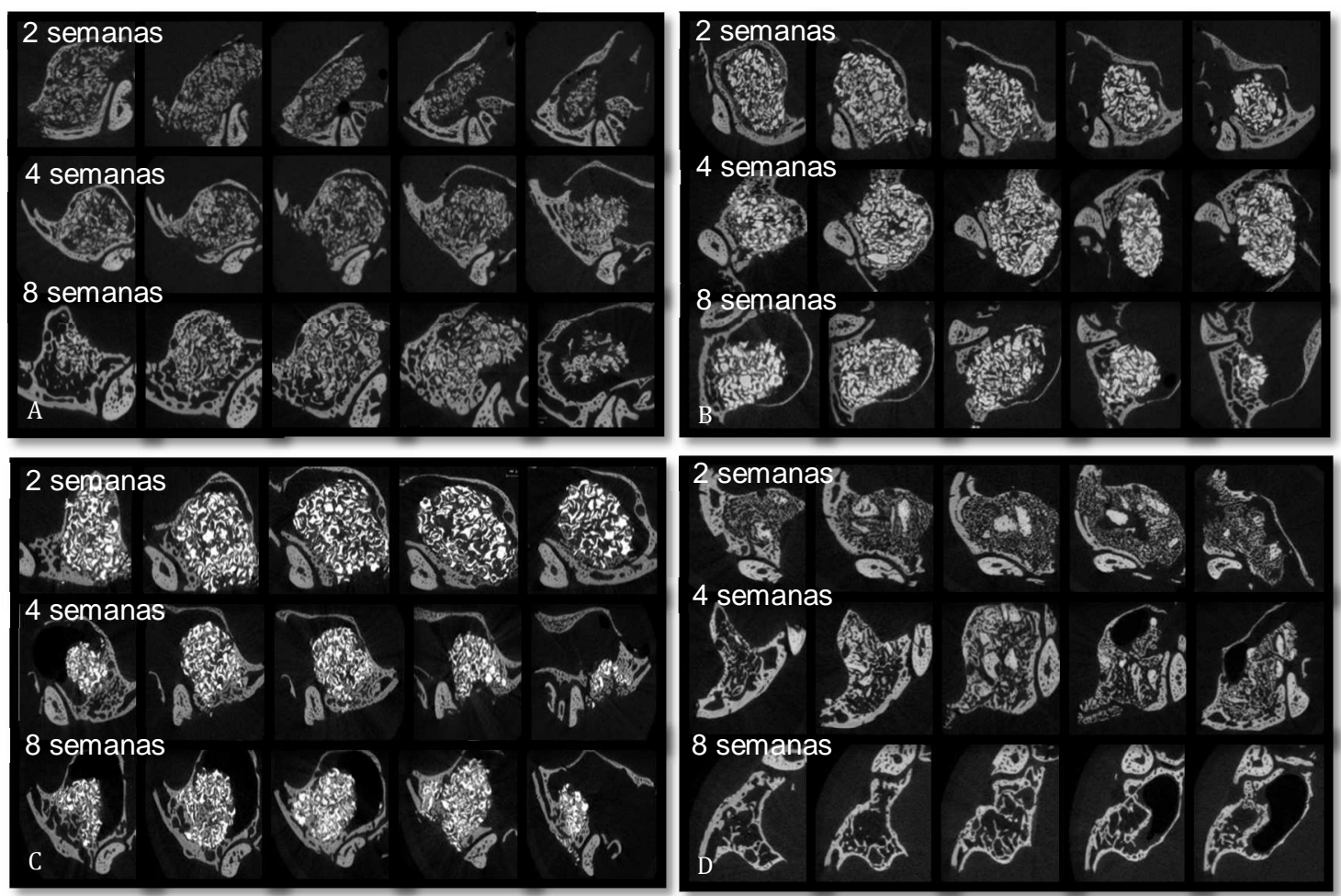

Figura 36 - Imagens ilustrativas de reconstruções bidimensionais microtomográficas de uma amostra por período, de cada grupo. A. OsteoScaf ${ }^{\mathrm{TM}} ;$ B. Bio-Oss ${ }^{\circledR} ;$ C. BoneCeramic ${ }^{\circledR}$ e D. Osso autógeno

Diferente da observação macroscópica, nas microtomografias as partículas do grupo BI apareceram maiores quando comparadas com as dos grupos OS e BO (Figura 37). O formato das partículas foi nitidamente observado em ambos biomateriais não totalmente biodegradáveis, enquanto as partículas de OS mostraram sua geometria muito similar à do osso autógeno, sendo difícil diferenciá-las entre si (Figura 37).

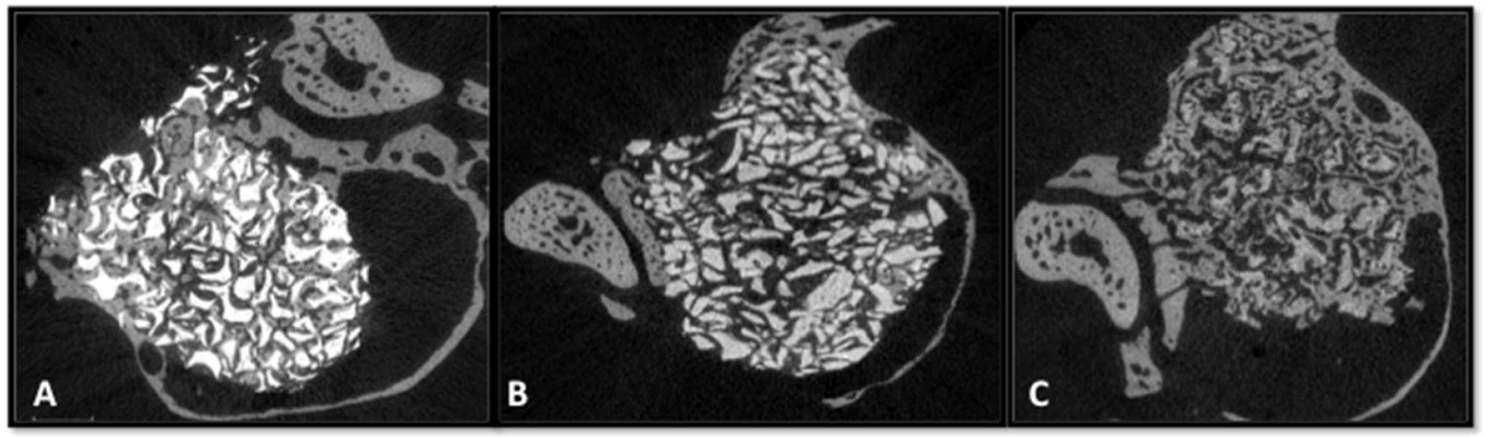

Figura 37 - A. Partículas de BoneCeramic ${ }^{\circledR} ;$ B. Bio-Oss ${ }^{\circledR}$ e C. OsteoScaf ${ }^{\mathrm{TM}}$ após 8 semanas de levantamento de seio maxilar 

A menor quantidade de neoformação óssea foi observada com 2 semanas em todos os grupos. Nos períodos de 4 e 8 semanas, respectivamente, ela se apresentou maior, nos grupos dos substitutos ósseos, diferente do osso autógeno, o qual revelou maior reabsorção ao longo do tempo (Figura 36D, 38-40).

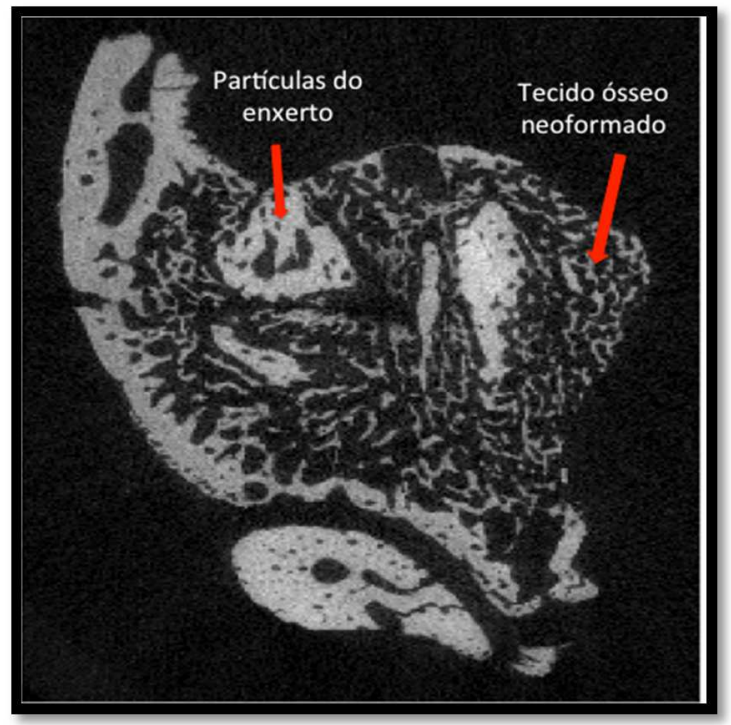

Figura 38 - Osso autógeno, período de 2 semanas. A presença de partículas maiores e mais hiperdensas corresponde ao enxerto, enquanto finas trábeculas ósseas correspondem ao tecido ósseo neoformado

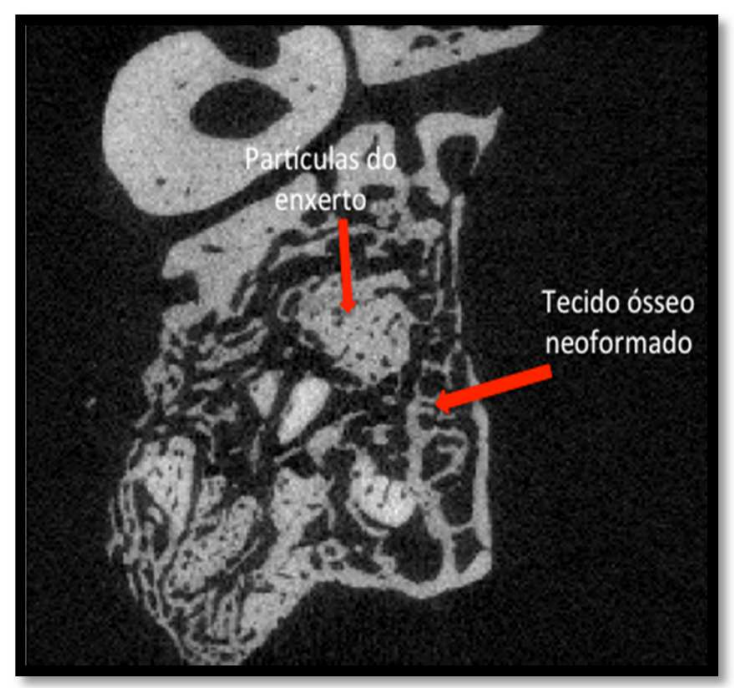

Figura 39 - Osso autógeno, período de 4 semanas. A presença das partículas do enxerto embora remodeladas, ainda permaneceram com novas finas trábeculas ósseas circundando-as. $\mathrm{O}$ volume total se apresentou igual ou menor ao período de 2 semanas 



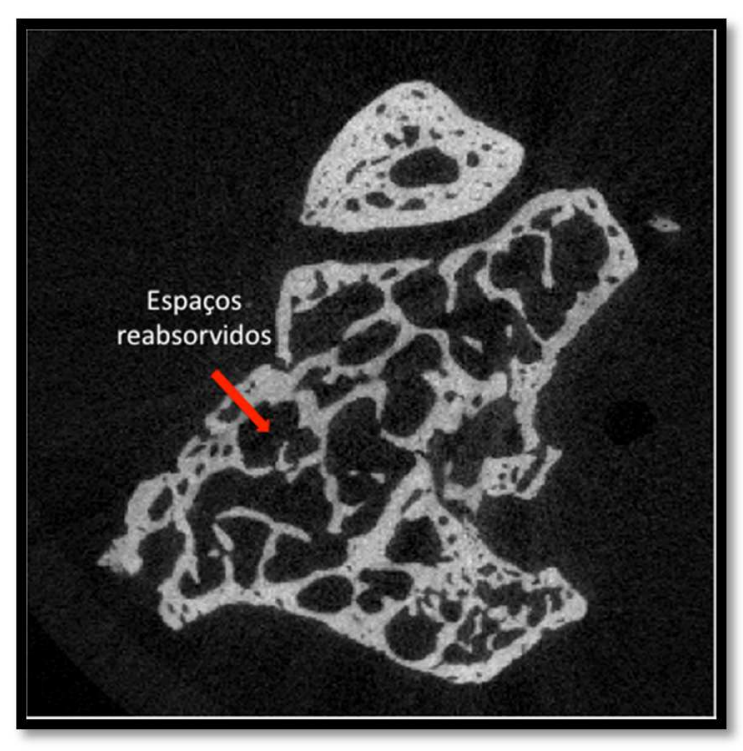

Figura 40 - Osso autógeno, período de 8 semanas. Ausência de partículas do enxerto original que foi remodelado e a presença de espaços vazios entre as trabéculas. A reabsorção óssea com 8 semanas se apresentou significante comparada aos outros períodos e grupos experimentais

Devido à diferença de densidade dos grupos $\mathrm{BI}$ e $\mathrm{BO}$, quando comparado ao osso neoformado, foi fácil avaliar a presença de tecido ósseo nesses grupos (Figuras 42, 43, 45, 46, 48, 49). Entretanto, no período de 2 semanas, o grupo OS demonstrou densidade muito similar ao tecido ósseo, tornando difícil e duvidosa a avaliação de neoformação óssea neste grupo (Figura 46). O mesmo ocorreu entre as partículas novas e as originais do osso autógeno, as quais foram incapazes de distinção entre as menores partículas enxertadas (Figuras 38-40). Ao longo do tempo, e com o aumento de neoformação óssea, a distinção entre o grupo OS e o tecido ósseo neoformado tornou-se mais nítida (Figuras 41, 44).

Comparando a distribuição do volume ósseo observado entre os grupos, nos períodos de 8 e 4 semanas, os grupos OS, BI e BO demonstraram neoformação óssea não somente na periferia da área submetida ao levantamento de seio maxilar, como também na sua área central (Figuras 44-49). No período de 2 semanas, foi observada menor quantidade de neoformacão óssea na região central, comparada à periferia, em todos os grupos (Figuras 47-49). Ainda, o comportamento dos grupos BI $\mathrm{e}$ BO foram bem similares na região central do enxerto, mostrando maior quantidade de partículas e menor de osso neoformado. O grupo OS apresentou dificuldades em definir, exatamente, a presença de osso nesse período, diante da similaridade de sua densidade ao tecido ósseo (Figuras 47).

Apenas o grupo OS, em todos os períodos, revelou um comportamento biodegradável, sendo representado pelas partículas degradadas, bem diferente do aspecto macroscópico inicial das mesmas. 



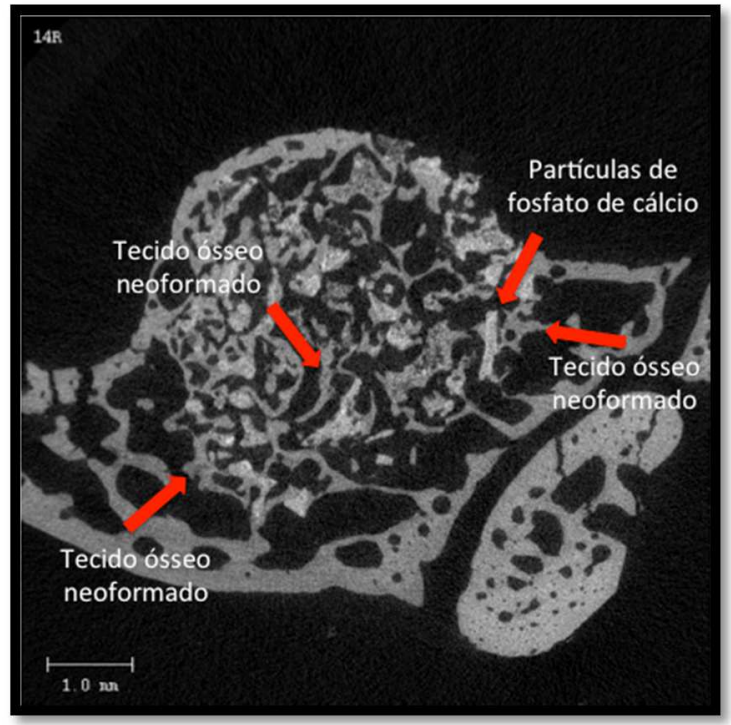

Figura 41 - OsteoScaf ${ }^{\mathrm{TM}}$, período de 8 semanas. Presença de algumas partículas de fosfato de cálcio, em permeio ao novo tecido ósseo, após a degradação do biomaterial. As trabéculas ósseas se apresentaram interconectadas entre si nas áreas periférica e central

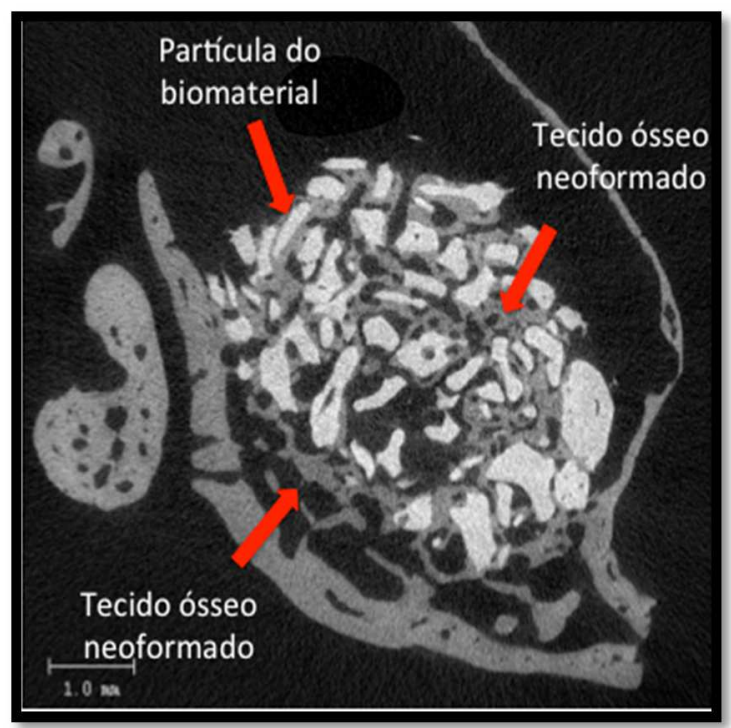

Figura 42 - Bio-Oss ${ }^{\circledR}$, período de 8 semanas. As partículas se apresentaram bem definidas, preservando o formato original e demonstrando ausência de degradação. As trabéculas ósseas circundaram o biomaterial e se interconectaram nas áreas periférica e central 



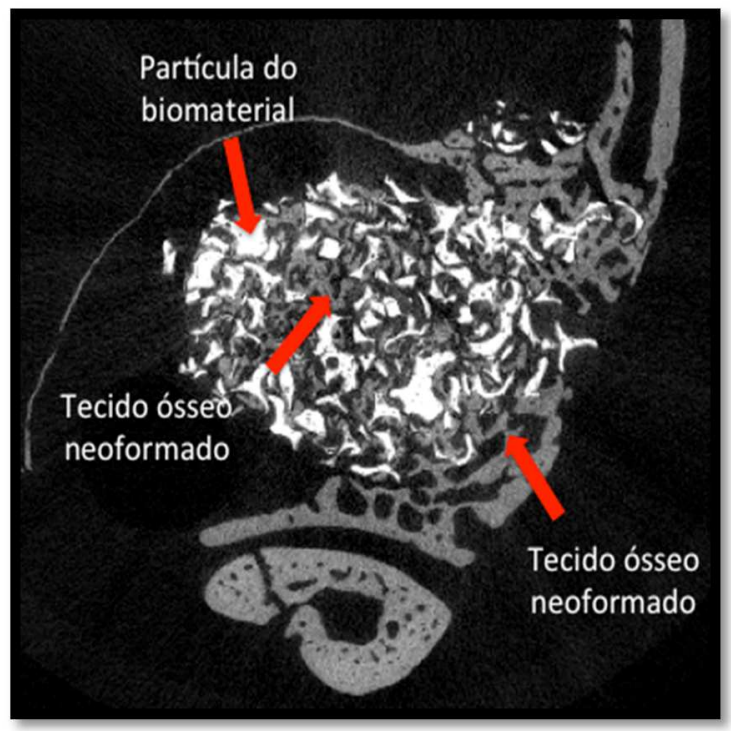

Figura 43 - BoneCeramic $®$, período de 8 semanas. Partículas apresentaram integridade no formato original, demonstrando ausência total de degradação, somente pequenas áreas hipodensas na superfície do biomaterial sugeriram uma leve degradação. As trabéculas ósseas circundaram o biomaterial e se interconectaram nas áreas periférica e central

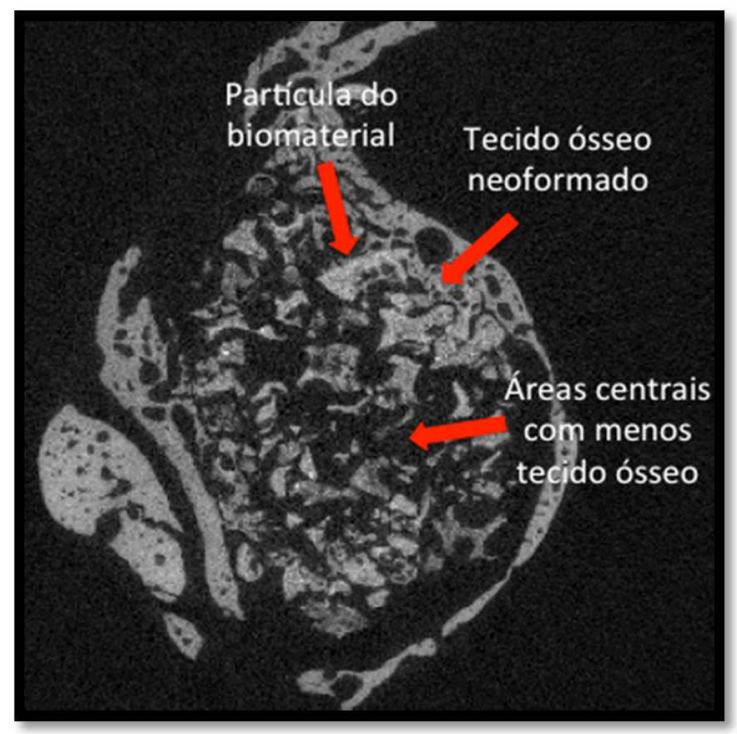

Figura 44 - OsteoScaf ${ }^{\mathrm{TM}}$, período de 4 semanas. Menor presença de tecido ósseo neoformado nas áreas periféricas e principalmente, nas áreas centrais, comparada ao período de 8 semanas 



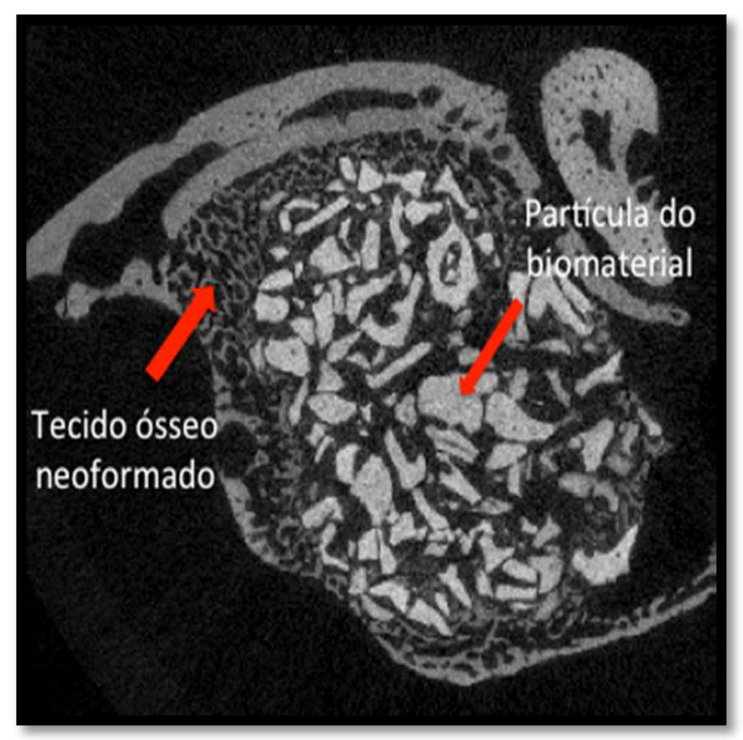

Figura 45 - Bio-Oss®, período de 4 semanas. Maior neoformação óssea periférica comparada às regiões centrais

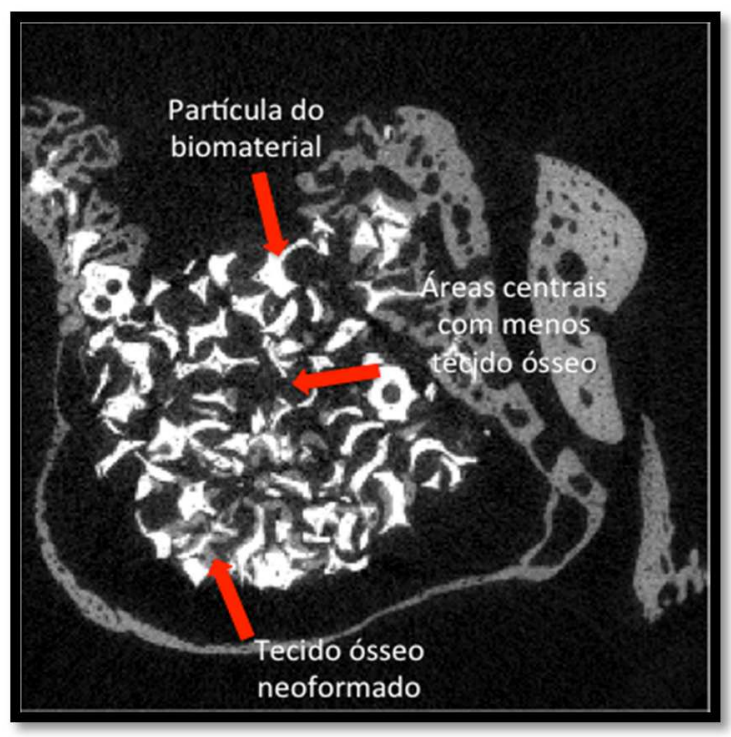

Figura 46 - BoneCeramic ${ }^{\circledR}$, período de 4 semanas. Presença de osso circundando as partículas do biomaterial, porém menor presença de trabéculas ósseas, principalmente, nas áreas centrais 



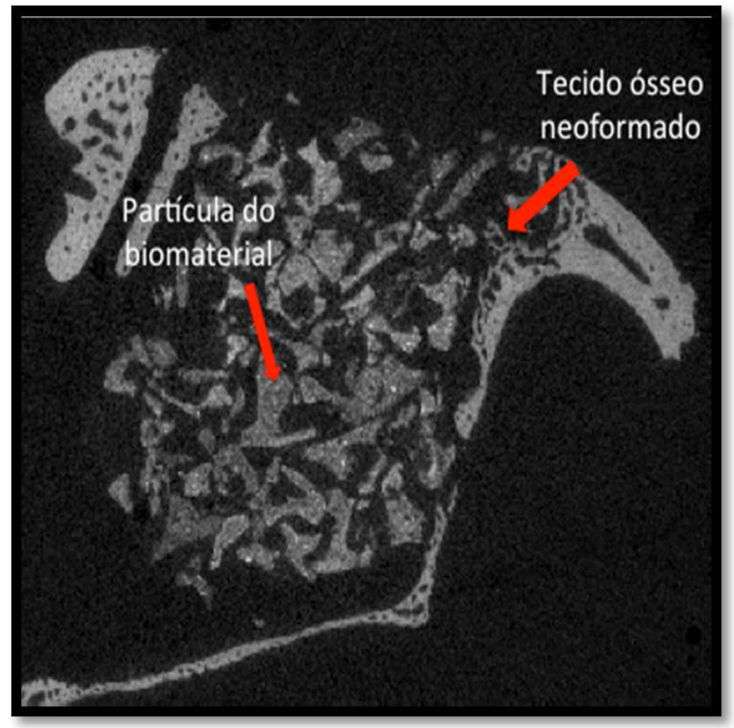

Figura 47 - OsteoScaf ${ }^{\mathrm{TM}}$, período de 2 semanas. Partículas do biomaterial parcialmente degradadas. Presença de menor formação óssea quando comparada aos outros períodos e dificuldade em diferenciar tecido ósseo neoformado das partículas do biomaterial

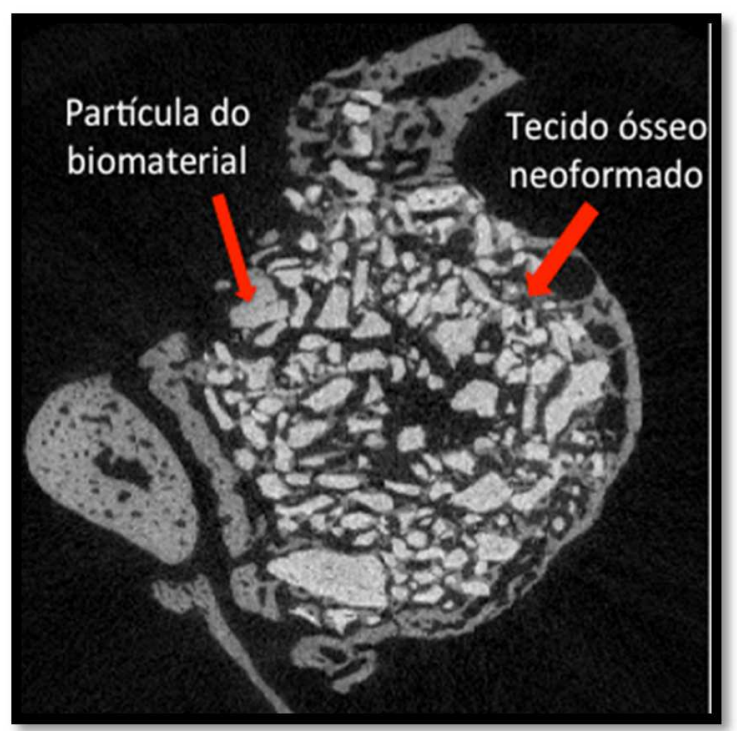

Figura 48 - Bio-Oss ${ }^{\circledR}$, período de 2 semanas. Período de menor neoformação óssea, principalmente, nas áreas centrais. Presença de tecido ósseo circundando as partículas, porém menor presença e conexão entre as trabéculas 



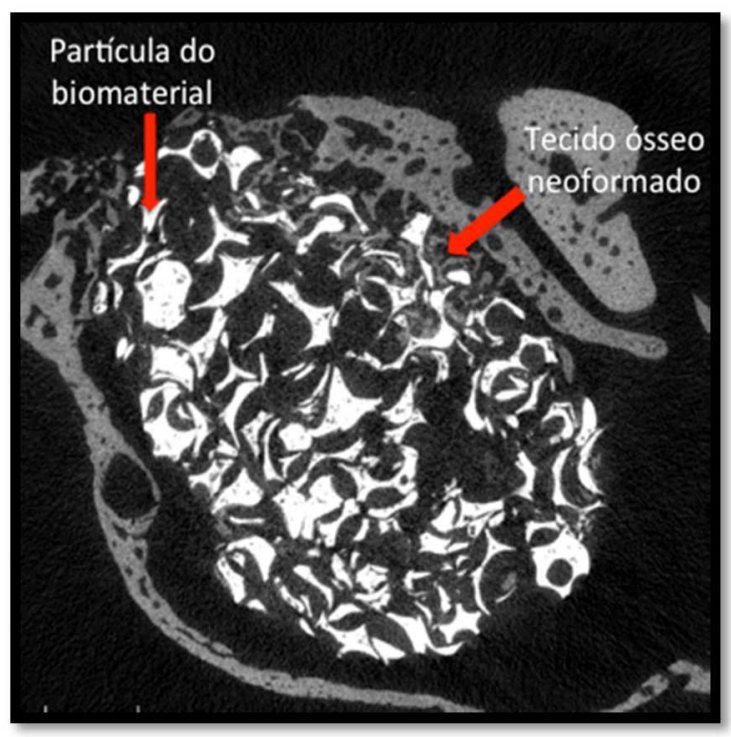

Figura 49 - BoneCeramic ${ }^{\circledR}$, período de 2 semanas. Menor neoformação óssea comparada aos outros períodos, principalmente, na área central

\subsubsection{Análise quantitativa}

Os resultados da histomorfometria [volume total (VT), volume ósseo (VO), relação entre volume ósseo e volume total (VO/VT), número de trabéculas (NT), espessura das trabéculas (ET) e separação entre as trabéculas (ST)], realizada pelo MicroCT (MicroCT40, Scanco Medical, Basserdorf, Suíça) foram descritos na forma de tabelas, após os dados serem analisados estatisticamente, entre os grupos, por período e entre os períodos, por grupo, empregando-se os testes de variância (ANOVA) a dois critérios e teste de Tukey, quando necessário. Além disso, alguns gráficos foram realizados para facilitar a compreensão dos resultados.

Os grupos foram abreviados nos gráficos da seguinte forma: OsteoScaf ${ }^{\mathrm{TM}}$ (BoneTec Corp - TRT, Toronto, Canadá) (OS), Bio-Oss ${ }^{\circledR}$ (Geistlich Biomaterials, Wolhusen, CH, Suíça) (BI), BoneCeramic ${ }^{\circledR}$ (Instituto Straumann AG, Basel, Suíça) (BO) e osso autógeno $(\mathrm{AU})$. 



\subsubsection{Variável volume total (VT)}

Tabela 3 - Média e desvio-padrão do VT em $\mathrm{mm}^{3}$, por grupo, em cada período estudado. Os dados foram analisados estatisticamente entre os grupos, por período e entre os períodos, por grupo, empregando-se os testes de variância ANOVA a dois critérios e teste de Tukey

\begin{tabular}{|c|c|c|c|c|c|c|}
\hline PERIODO & ANIMAL & OSTEOSCAFTM & BIO-OSS $®$ & BONECERAMIC@ & AUTOGENO & $\begin{array}{c}\text { DIF. } \\
\text { GRUPOS }\end{array}$ \\
\hline \multirow[t]{2}{*}{2 SEMANAS } & Média & $108,243 \mathbf{a B}$ & $130,734 \mathbf{b B}$ & $106,867 \mathbf{a B}$ & $111,164 \mathbf{a B}$ & \multirow{6}{*}{$\mathbf{P}<0,001 *$} \\
\hline & DP & 17,920 & 20,891 & 11,548 & 14,982 & \\
\hline \multirow[t]{2}{*}{4 SEMANAS } & Média & $106,293 \mathbf{a A B}$ & $132,604 \mathbf{b A B}$ & $109,993 \mathbf{a A B}$ & $87,746 \mathbf{a A B}$ & \\
\hline & DP & 12,631 & 8,369 & 10,391 & 14,932 & \\
\hline \multirow[t]{2}{*}{8 SEMANAS } & Média & $107,338 \mathbf{a A}$ & $115,577 \mathbf{b A}$ & $91,304 \mathbf{a A}$ & $86,228 \mathbf{a A}$ & \\
\hline & DP & 7,496 & 10,856 & 9,163 & 27,203 & \\
\hline $\begin{array}{c}\text { DIF. } \\
\text { PERIODOS }\end{array}$ & \multicolumn{6}{|c|}{$\mathrm{P}=0,007 *$} \\
\hline
\end{tabular}

* $\mathrm{P}<0,05$ = estatisticamente significante. Grupos com a mesma letra minúscula não possuem diferença entre si. Períodos com o mesmo conjunto de letra maiúscula não possuem diferença entre si

Tabela 4 - Resultados da análise de variância (ANOVA) a 2 critérios para o VT

\begin{tabular}{cccccccc}
\hline & $\begin{array}{c}\text { df } \\
\text { Effect }\end{array}$ & $\begin{array}{c}\text { MS } \\
\text { Effect }\end{array}$ & $\begin{array}{c}\text { df } \\
\text { Error }\end{array}$ & $\begin{array}{c}\text { MS } \\
\text { Error }\end{array}$ & F & p-level \\
\hline 1 & 3 & 3186,84033 & 60 & 226,180634 & 14,0898018 & $\mathbf{0 , 0 0 0 0 0 0 5 *}^{*}, 0,00672848$ \\
\hline $\mathbf{2}$ & 2 & 1230,98218 & 60 & 226,180634 & 5,44247389 & 0,006884717 \\
\hline 12 & 6 & 357,23056 & 60 & 226,180634 & 1,57940376 & 0,16884 \\
\hline
\end{tabular}

1. Grupo; 2. Período. *significância para $\mathrm{p}<0,05$

Tabela 5 - Resultados da comparação entre grupos. Teste de Tukey para o VT

\begin{tabular}{|c|c|c|c|c|c|}
\hline & & $\{1\}$ & $\{2\}$ & $\{3\}$ & $\{4\}$ \\
\hline & & 107,2914 & 126,3047 & 102,7213 & 95,04581 \\
\hline 1 & $\ldots \quad\{1\}$ & & $0,002035856 *$ & 0,798782349 & 0,080025434 \\
\hline 2 & $\ldots \quad\{2\}$ & 0,002035856 & & $0,000232637 *$ & $0,000155449 *$ \\
\hline 3 & $\ldots\{3\}$ & 0,798782349 & 0,000232637 & & 0,425721228 \\
\hline 4 & $\ldots \quad\{4\}$ & 0,080025434 & 0,000155449 & 0,425721228 & \\
\hline
\end{tabular}

1.OS; 2.BI; 3.BO; 4.AU. *significância para p<0,05

Tabela 6 - Resultados da comparação entre períodos. Teste de Tukey para o VT

\begin{tabular}{llccc}
\hline & & $\{1\}$ & $\{2\}$ & $\{3\}$ \\
\hline$\ldots .8$ weeks $\{1\}$ & 100,1115 & 109,1589 & 114,2520 \\
$\ldots$ & & 0,10184586 & $\mathbf{0 , 0 0 5 2 9 4 2 6 3 *}$ \\
$\ldots$ 2 & & & 0,473760843 \\
\hline
\end{tabular}

*significância para $\mathrm{p}<0,05$ 


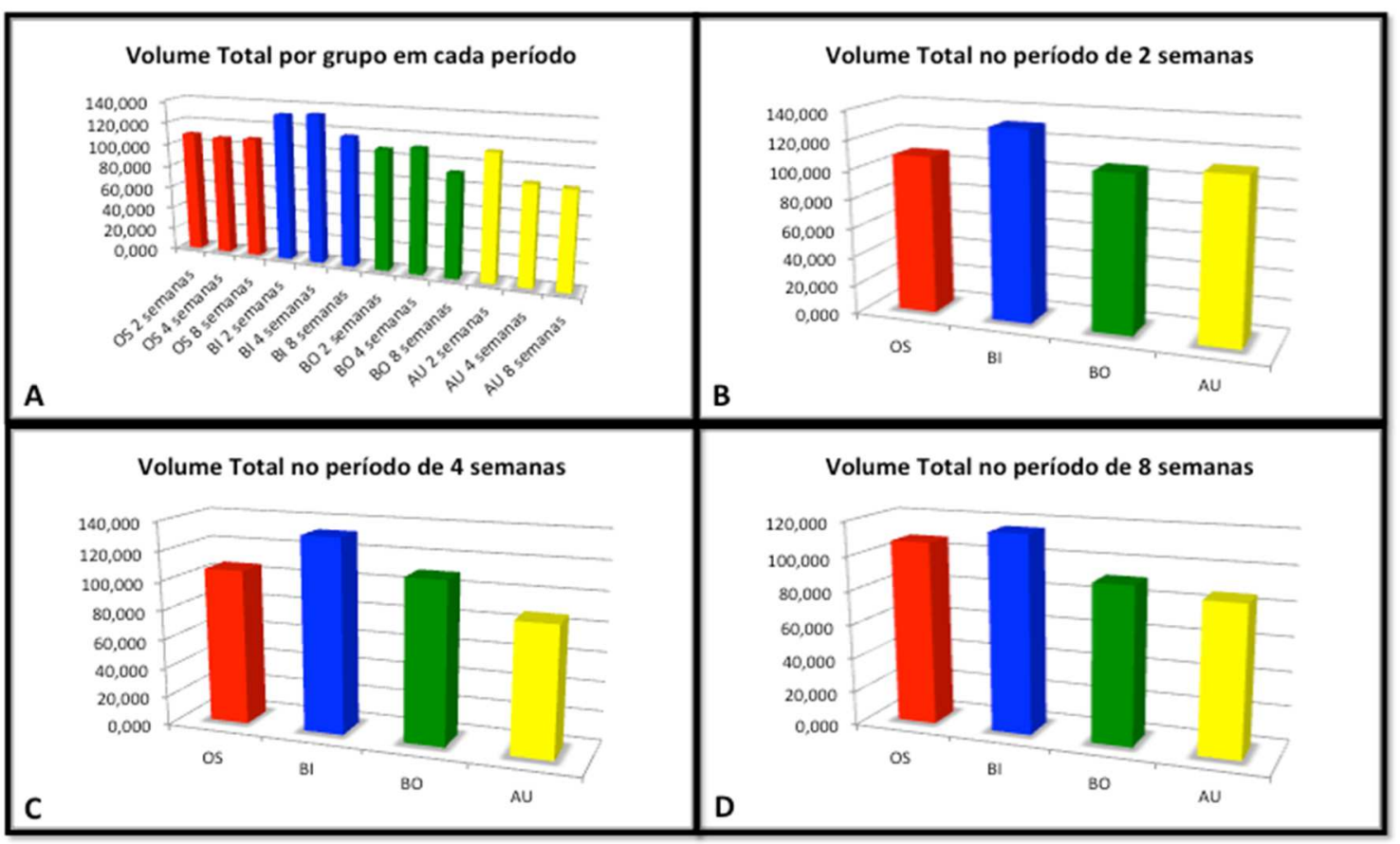

Figura 50 - Gráficos ilustrativos dos resultados do VT em $\mathrm{mm}^{3}$. A. Evolução do VT de cada grupo, ao longo do tempo. B. VT de cada grupo no período de 2 semanas. C. VT de cada grupo no período de 4 semanas. D. VT de cada grupo no período de 8 semanas. OS: OsteoScaf ${ }^{\mathrm{TM}}$, BI: Bio-Oss ${ }^{\circledR}, \mathrm{BO}$ : BoneCeramic ${ }^{\circledR}$ e AU: osso autógeno

\subsubsection{Variável volume ósseo neoformado (VO)}

Tabela 7 - Média e desvio-padrão do VO neoformado em $\mathrm{mm}^{3}$, por grupo, em cada período estudado. Os dados foram analisados estatisticamente entre os grupos, por período e entre os períodos, por grupo, empregando-se os testes de variância ANOVA a dois critérios e teste de Tukey

\begin{tabular}{|c|c|c|c|c|c|}
\hline PERIODO & ANIMAL & OSTEOSCAFTM & BIO-OSS@ & BONECERAMIC@ & $\begin{array}{l}\text { DIF.GRUPOS } \\
\text { (por período) }\end{array}$ \\
\hline \multirow[t]{2}{*}{2 SEMANAS } & Média & $33,961 \mathbf{b}$ & $34,590 \mathbf{b}$ & $21,293 \mathbf{a}$ & \multirow{7}{*}{$\mathrm{P}<0,001 *$} \\
\hline & DP & 3,479 & 6,069 & 6,333 & \\
\hline \multirow[t]{2}{*}{4 SEMANAS } & Média & $34,986 \mathbf{b}$ & $36,426 \mathbf{b}$ & $24,543 \mathbf{a}$ & \\
\hline & DP & 3,784 & 1,721 & 2,810 & \\
\hline \multirow[t]{2}{*}{8 SEMANAS } & Média & $35,222 \mathbf{b}$ & $32,029 \mathbf{b}$ & $26,969 \mathbf{a}$ & \\
\hline & DP & 4,187 & 2,638 & 2,638 & \\
\hline $\begin{array}{l}\text { DIF. PERIODOS } \\
\text { (por grupo) }\end{array}$ & \multicolumn{4}{|c|}{$P=0,303$} & \\
\hline
\end{tabular}

* $\mathrm{P}<0,05$ = estatisticamente significante. Grupos com a mesma letra minúscula não possuem diferença entre si

Tabela 8 - Resultados da análise de variância (ANOVA) a 2 critérios para o VO

\begin{tabular}{|c|c|c|c|c|c|c|}
\hline & $\begin{array}{c}\text { df } \\
\text { Effect }\end{array}$ & $\begin{array}{c}\text { MS } \\
\text { Effect }\end{array}$ & $\begin{array}{l}\text { df } \\
\text { Error }\end{array}$ & $\begin{array}{c}\text { MS } \\
\text { Error }\end{array}$ & $\mathbf{F}$ & p-level \\
\hline 1 & 2 & 633,168152 & 45 & 16,1856842 & 39,1190224 & $0,0000000 *$ \\
\hline 2 & 2 & 19,8375378 & 45 & 16,1856842 & 1,22562253 & 0,30318677 \\
\hline 12 & 4 & 30,3931999 & 45 & 16,1856842 & 1,87778282 & 0,13084909 \\
\hline
\end{tabular}

1. Grupo; 2. Período. *significância para p<0,05 
Tabela 9 - Resultados da comparação entre grupos. Teste de Tukey para o VO

\begin{tabular}{|c|c|c|c|}
\hline & $\{1\}$ & $\{2\}$ & $\{3\}$ \\
\hline & 34,72304 & 34,34839 & 24,26816 \\
\hline $1 \quad \ldots \quad\{1\}$ & & 0,958013594 & $0,0001297^{*}$ \\
\hline $2 \quad \ldots .\{2\}$ & 0,958013594 & & $0,0001297 *$ \\
\hline $\begin{array}{lll}3 & \ldots & \{3\}\end{array}$ & $0,0001297 *$ & $0,0001297 *$ & \\
\hline
\end{tabular}

1.OS; 2.BI; 3.BO. *significância para $\mathrm{p}<0,05$

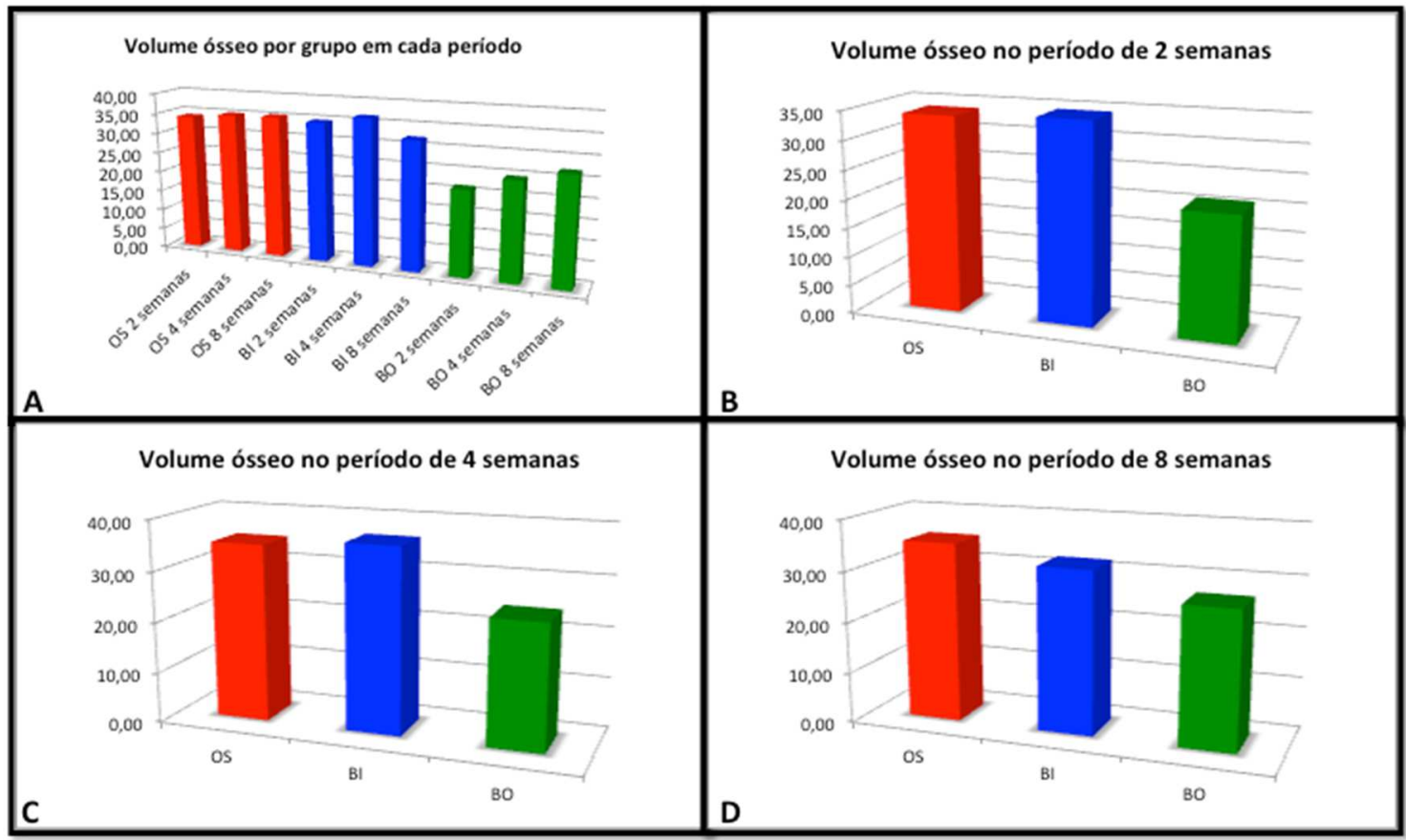

Figura 51 - Gráficos ilustrativos dos resultados do $\mathrm{VO}$ em $\mathrm{mm}^{3}$. A. Evolução do $\mathrm{VO}$ ao longo do tempo, de cada grupo. B. VO de cada grupo no período de 2 semanas. C. VO de cada grupo no período de 4 semanas. D. VO de cada grupo no período de 8 semanas. OS: OsteoScaf ${ }^{\mathrm{TM}}, \mathrm{BI}$ : Bio-Oss ${ }^{\circledR}, \mathrm{BO}$ : BoneCeramic ${ }^{\circledR}$ 


\subsubsection{Variável relação volume ósseo neoformado/volume total (VO/VT)}

Tabela 10 - Média e desvio-padrão da relação do VO/VT, por grupo, em cada período estudado. Os dados foram analisados estatisticamente entre os grupos, por período e entre os períodos, por grupo, empregando-se os testes de variância ANOVA a dois critérios e teste de Tukey

\begin{tabular}{|c|c|c|c|c|c|}
\hline PERIODO & ANIMAL & OSTEOSCAFTM & BIO-OSS $®$ & BONECERAMIC@ & $\begin{array}{l}\text { DIF.GRUPOS } \\
\text { (por período) }\end{array}$ \\
\hline \multirow[t]{2}{*}{2 SEMANAS } & Média & $0,318 \mathbf{c}$ & $0,266 \mathbf{a b c}$ & $0,198 \mathbf{a}$ & \multirow{7}{*}{$\mathbf{P}<0,001^{*}$} \\
\hline & DP & 0,035 & 0,035 & 0,045 & \\
\hline \multirow[t]{2}{*}{4 SEMANAS } & Média & $0,331 \mathbf{c}$ & $0,274 \mathbf{b c}$ & $0,224 \mathbf{a b}$ & \\
\hline & DP & 0,038 & 0,014 & 0,022 & \\
\hline \multirow[t]{2}{*}{8 SEMANAS } & Média & $0,330 \mathbf{c}$ & 0,278 bc & $0,300 \mathbf{c}$ & \\
\hline & DP & 0,042 & 0,026 & 0,059 & \\
\hline $\begin{array}{l}\text { DIF. } \\
\text { PERIODOS } \\
\text { (por grupo) }\end{array}$ & \multicolumn{4}{|c|}{$P=0,005^{*}$} & \\
\hline
\end{tabular}

* $\mathrm{P}<0,05$ = estatisticamente significante. Grupos com a mesma letra minúscula não possuem diferença entre si

Tabela 11 - Resultados da análise de variância (ANOVA) a 2 critérios para a relação VO/VT

\begin{tabular}{|c|c|c|c|c|c|c|}
\hline & $\begin{array}{c}\text { df } \\
\text { Effect }\end{array}$ & $\begin{array}{c}\text { MS } \\
\text { Effect }\end{array}$ & $\begin{array}{l}\text { df } \\
\text { Error }\end{array}$ & $\begin{array}{c}\text { MS } \\
\text { Error }\end{array}$ & F & p-level \\
\hline 1 & 2 & 0,034079373 & 45 & 0,001394576 & 24,43707848 & $0,000000 *$ \\
\hline 2 & 2 & 0,008321537 & 45 & 0,001394576 & 5,967071533 & $0,005027983 *$ \\
\hline 12 & 4 & 0,004619631 & 45 & 0,001394576 & 3,312569857 & $0,018394733 *$ \\
\hline
\end{tabular}

1. Grupo; 2. Período. *significância para p<0,05

Tabela 12 - Resultados da interação. Teste de Tukey para a relação VO/VT

\begin{tabular}{|c|c|c|c|c|}
\hline & Mean & 1 & 2 & 3 \\
\hline 32 weeks $\{9\}$ & 0,197683334 & $\mathrm{a}$ & & \\
\hline 34 weeks $\{8\}$ & 0,223550007 & $\mathrm{a}$ & $\mathrm{b}$ & \\
\hline 22 weeks $\{6\}$ & 0,265833348 & $\mathrm{a}$ & $\mathrm{b}$ & $\mathrm{c}$ \\
\hline 24 weeks $\{5\}$ & 0,273799986 & & $\mathrm{~b}$ & $\mathrm{c}$ \\
\hline 28 weeks $\{4\}$ & 0,278483331 & & $\mathrm{~b}$ & $\mathrm{c}$ \\
\hline 38 weeks $\{7\}$ & 0,299950004 & & & $\mathrm{c}$ \\
\hline 12 weeks $\{3\}$ & 0,317716658 & & & $\mathrm{c}$ \\
\hline 18 weeks $\{1\}$ & 0,330433339 & & & $\mathrm{c}$ \\
\hline 14 weeks $\{2\}$ & 0,331433326 & & & $\mathrm{c}$ \\
\hline
\end{tabular}

1.OS; 2.BI; 3.BO. Conjuntos com a mesma letra não possuem diferença entre si. 


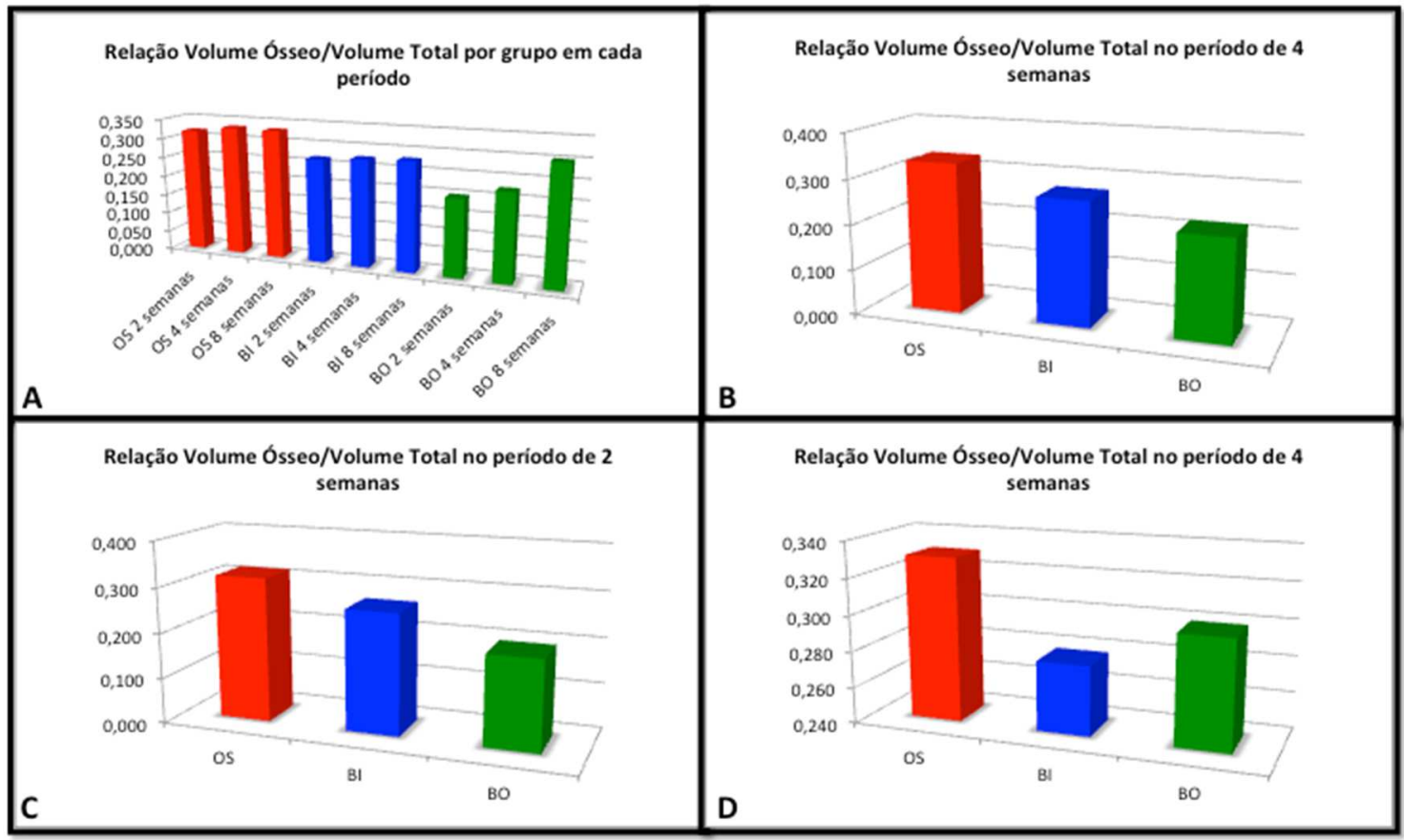

Figura 52 - Gráficos ilustrativos dos resultados da relação VO/VT. A. Evolução da VO/VT ao longo do tempo, de cada grupo. B. VO/VT de cada grupo no período de 2 semanas. C. VO/VT de cada grupo no período de 4 semanas. D. VO/VT de cada grupo no período de 8 semanas. OS: OsteoScaf ${ }^{\mathrm{TM}}$, BI: Bio-Oss ${ }^{\circledR}, \mathrm{BO}$ : BoneCeramic ${ }^{\circ}$

\subsubsection{Variável número de trabéculas (NT)}

Tabela 13 - Média e desvio-padrão do NT, por grupo, em cada período estudado. Os dados foram analisados estatisticamente entre os grupos, por período e entre os períodos, por grupo, empregando-se os testes de variância ANOVA a dois critérios e teste de Tukey

\begin{tabular}{|c|c|c|c|c|c|}
\hline PERIODO & ANIMAL & OSTEOSCAFTM & BIO-OSS $®$ & BONECERAMIC@ & $\begin{array}{l}\text { DIF.GRUPOS } \\
\text { (por período) }\end{array}$ \\
\hline \multirow[t]{2}{*}{2 SEMANAS } & Média & $4,568 \mathbf{a}$ & $7,032 \mathbf{b}$ & 7,485 b & \multirow{7}{*}{$\mathrm{P}<0,001 *$} \\
\hline & DP & 0,511 & 2,064 & 1,000 & \\
\hline 4 SEMANAS & Média & $5,716 \mathbf{a}$ & $7,302 \mathbf{b}$ & $6,806 \mathbf{b}$ & \\
\hline & DP & 0,845 & 0,590 & 1,670 & \\
\hline 8 SEMANAS & Média & $4,682 \mathbf{a}$ & $6,136 \mathbf{b}$ & 7,119 b & \\
\hline & DP & 0,554 & 1,034 & 2,237 & \\
\hline $\begin{array}{l}\text { DIF. } \\
\text { PERIODOS } \\
\text { (por grupo) }\end{array}$ & \multicolumn{4}{|c|}{$P=0,365$} & \\
\hline
\end{tabular}

* $\mathrm{P}<0,05$ = estatisticamente significante. Grupos com a mesma letra minúscula não possuem diferença entre si 
Tabela 14 - Resultados da análise de variância (ANOVA) a 2 critérios para o NT

\begin{tabular}{|c|c|c|c|c|cc}
\hline & $\begin{array}{c}\text { df } \\
\text { Effect }\end{array}$ & $\begin{array}{c}\text { MS } \\
\text { Effect }\end{array}$ & $\begin{array}{c}\text { df } \\
\text { Error }\end{array}$ & $\begin{array}{c}\text { MS } \\
\text { Error }\end{array}$ & F & p-level \\
\hline 1 & 2 & 24,2335491 & 45 & 1,75070691 & 13,8421516 & $\mathbf{0 , 0 0 0 0 2 0 6 *}$ \\
\hline $\mathbf{2}$ & 2 & 1,80591023 & 45 & 1,75070691 & 1,03153193 & 0,364734739 \\
\hline 12 & 4 & 1,75881851 & 45 & 1,75070691 & 1,00463331 & 0,415133387 \\
\hline
\end{tabular}

1. Grupo; 2. Período. *significância para p<0,05

Tabela 15 - Resultados da comparação entre grupos. Teste de Tukey para o NT

\begin{tabular}{|c|c|c|c|}
\hline & $\{1\}$ & $\{2\}$ & $\{3\}$ \\
\hline & 4,988817 & 6,823317 & 7,136872 \\
\hline $1 \quad \ldots .\{1\}$ & & $0,000519156^{*}$ & $0,000165105 *$ \\
\hline $2 \quad \ldots \quad\{2\}$ & 0,000519156 & & 0,758411825 \\
\hline $\begin{array}{lll}3 & \ldots . & \{3\}\end{array}$ & 0,000165105 & 0,758411825 & \\
\hline
\end{tabular}

1.OS; 2.BI; 3.BO. *significância para $\mathrm{p}<0,05$.

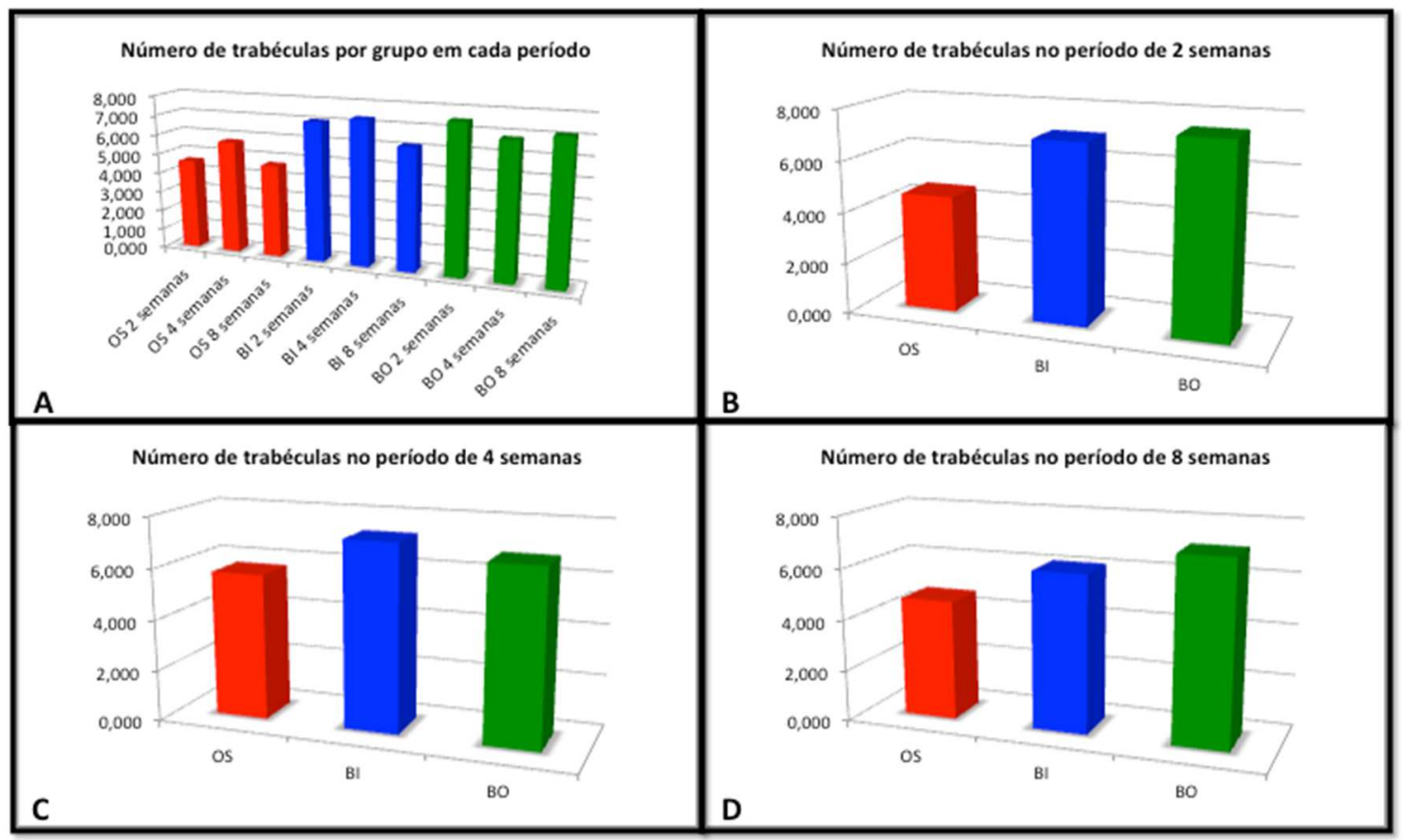

Figura 53 - Gráficos ilustrativos dos resultados do NT. A. Evolução do NT ao longo do tempo, de cada grupo. B. NT de cada grupo no período de 2 semanas. C. NT de cada grupo no período de 4 semanas. D. NT de cada grupo no período de 8 semanas. OS: OsteoScaf ${ }^{\mathrm{TM}}$, BI: Bio-Oss ${ }^{\circledR}, \mathrm{BO}$ : BoneCeramic ${ }^{\circledR}$ 


\subsubsection{Variável espessura das trabéculas (ET)}

Tabela 16 - Média e desvio-padrão da ET em mm, por grupo, em cada período estudado. Os dados foram analisados estatisticamente entre os grupos, por período e entre os períodos, por grupo, empregando-se os testes de variância ANOVA a dois critérios e teste de Tukey

\begin{tabular}{|c|c|c|c|c|c|}
\hline PERIODO & ANIMAL & OSTEOSCAFTM & BIO-OSS $®$ & BONECERAMIC@ & $\begin{array}{l}\text { DIF.GRUPOS } \\
\text { (por período) }\end{array}$ \\
\hline \multirow[t]{2}{*}{2 SEMANAS } & Média & $0,075 \mathbf{b}$ & $0,257 \mathbf{a b}$ & $0,035 \mathbf{a}$ & \multirow{7}{*}{$\mathrm{P}<0,05^{*}$} \\
\hline & DP & 0,013 & 0,062 & 0,006 & \\
\hline 4 SEMANAS & Média & $0,065 \mathbf{b}$ & $0,052 \mathbf{a b}$ & $0,048 \mathbf{a}$ & \\
\hline & DP & 0,015 & 0,004 & 0,008 & \\
\hline 8 SEMANAS & Média & $0,081 \mathbf{b}$ & $0,063 \mathbf{a b}$ & $0,069 \mathbf{a}$ & \\
\hline & DP & 0,022 & 0,009 & 0,042 & \\
\hline $\begin{array}{l}\text { DIF. } \\
\text { PERIODOS } \\
\text { (por grupo) }\end{array}$ & \multicolumn{4}{|c|}{$P=0,18$} & \\
\hline
\end{tabular}

Tabela 17 - Resultados da análise de variância (ANOVA) a 2 critérios para a ET

\begin{tabular}{ccccc|cc|}
\hline & $\begin{array}{c}\text { df } \\
\text { Effect }\end{array}$ & $\begin{array}{c}\text { MS } \\
\text { Effect }\end{array}$ & $\begin{array}{c}\text { df } \\
\text { Error }\end{array}$ & $\begin{array}{c}\text { MS } \\
\text { Error }\end{array}$ & F & p-level \\
\hline $\mathbf{1}$ & 2 & 0,0024207 & 45 & 0,00074158 & 3,264239073 & $\mathbf{0 , 0 4 7 4 4 7 8 9 *}$ \\
$\mathbf{2}$ & 2 & 0,00131863 & 45 & 0,00074158 & 1,778129339 & 0,18061934 \\
12 & 4 & 0,00065845 & 45 & 0,00074158 & 0,887906611 & 0,47892937 \\
\hline
\end{tabular}

1. Grupo; 2. Período. *significância para $\mathrm{p}<0,05$

Tabela 18 - Resultados da comparação entre grupos. Teste de Tukey para a ET

\begin{tabular}{cccccc}
\hline & & $\{1\}$ & $\{2\}$ & $\{3\}$ \\
\hline 1 & $\ldots$ & $\{1\}$ &, 0737000 &, 0605667 &, 0505778 \\
2 & $\ldots$ & $\{2\}$ & 0,326126635 & 0,326126635 & $\mathbf{0 , 0 3 7 5 5 8 9 7 3 *}$ \\
\hline 3 & $\ldots$ & $\{3\}$ & 0,037558973 & 0,518867612 \\
\hline
\end{tabular}

1.OS; 2.BI; 3.BO. *significância para $\mathrm{p}<0,05$ 


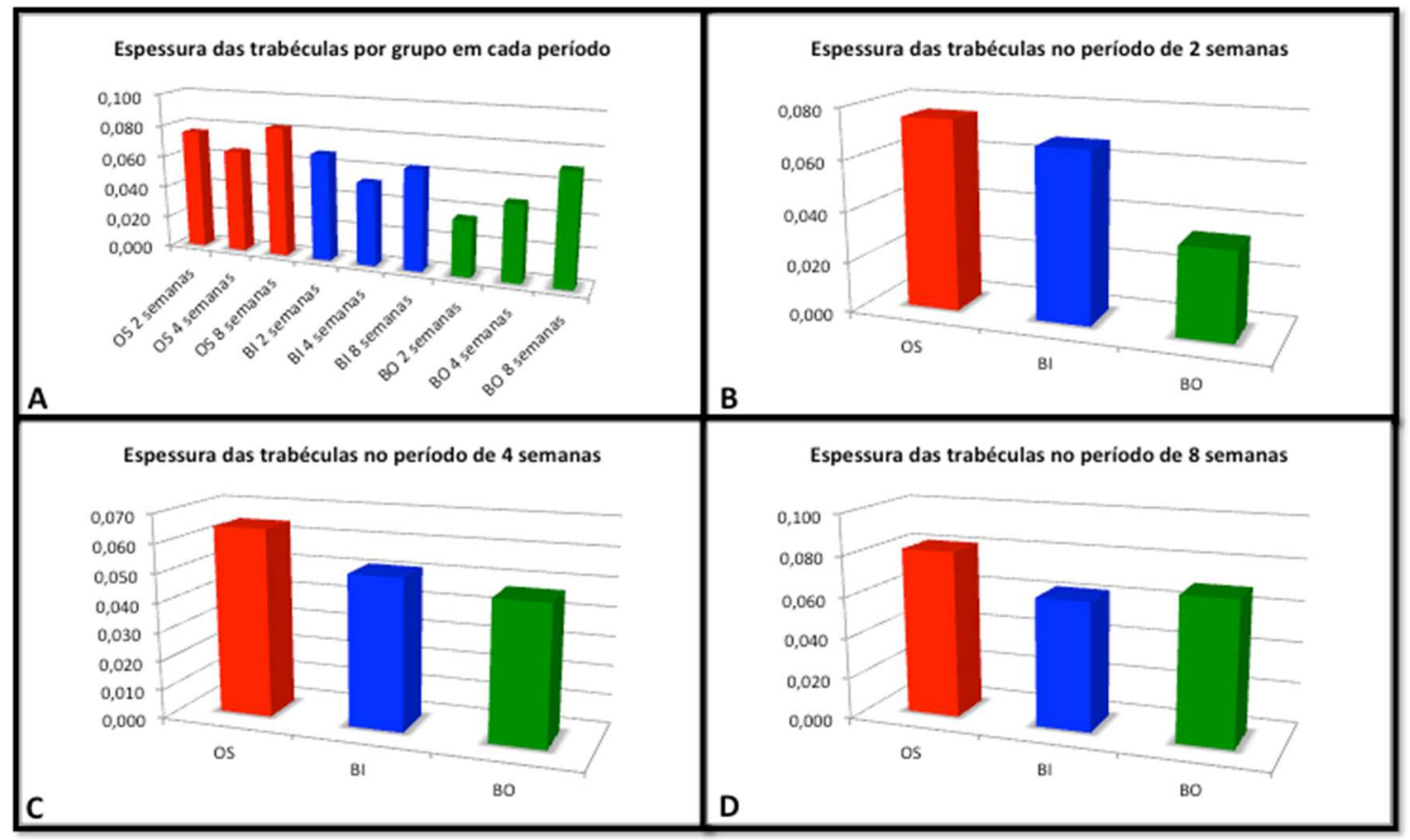

Figura 54 - Gráficos ilustrativos dos resultados da ET em mm. A. Evolução da ET ao longo do tempo, de cada grupo. B. ET de cada grupo no período de 2 semanas. C. ET de cada grupo no período de 4 semanas. D. ET de cada grupo no período de 8 semanas. OS: OsteoScaf ${ }^{\mathrm{TM}}$, BI: Bio-Oss ${ }^{\circledR}$, BO: BoneCeramic ${ }^{\circledR}$

\subsubsection{Variável separação entre as trabéculas (ST)}

Tabela 19 - Média e desvio-padrão da ST em mm, por grupo, em cada período estudado. Os dados foram analisados estatisticamente entre os grupos, por período e entre os períodos, por grupo, empregando-se os testes de variância ANOVA a dois critérios e teste de Tukey

\begin{tabular}{|c|c|c|c|c|c|}
\hline PERIODO & ANIMAL & OSTEOSCAFTM & BIO-OSS $®$ & BONECERAMIC@ & $\begin{array}{l}\text { DIF.GRUPOS } \\
\text { (por período) }\end{array}$ \\
\hline \multirow[t]{2}{*}{2 SEMANAS } & Média & $0,257 \mathbf{b}$ & $0,178 \mathbf{a}$ & $0,141 \mathbf{a}$ & \multirow{7}{*}{$\mathrm{P}<0,001 *$} \\
\hline & DP & 0,036 & 0,114 & 0,019 & \\
\hline 4 SEMANAS & Média & $0,207 \mathbf{b}$ & $0,143 \mathbf{a}$ & $0,162 \mathbf{a}$ & \\
\hline & DP & 0,028 & 0,015 & 0,032 & \\
\hline 8 SEMANAS & Média & $0,248 \mathbf{b}$ & $0,181 \mathbf{a}$ & $0,188 \mathbf{a}$ & \\
\hline & DP & 0,039 & 0,042 & 0,130 & \\
\hline $\begin{array}{l}\text { DIF. } \\
\text { PERIODOS } \\
\text { (por grupo) }\end{array}$ & \multicolumn{4}{|c|}{$P=0,27$} & \\
\hline
\end{tabular}

* $\mathrm{P}<0,05$ = estatisticamente significante. Grupos com a mesma letra minúscula não possuem diferença entre si. 
Tabela 20 - Resultados da análise de variância (ANOVA) a 2 critérios para o ST

\begin{tabular}{c|cc|c|c|c|c|}
\hline & $\begin{array}{c}\text { df } \\
\text { Effect }\end{array}$ & $\begin{array}{c}\text { MS } \\
\text { Effect }\end{array}$ & $\begin{array}{c}\text { df } \\
\text { Error }\end{array}$ & $\begin{array}{c}\text { MS } \\
\text { Error }\end{array}$ & F & p-level \\
\hline 1 & 2 & 0,030602394 & 45 & 0,004077916 & 7,50442028 \\
2 & 2 & 0,005551645 & 45 & 0,004077916 & 1,361392736 & 0,266656011 \\
12 & 4 & 0,002332067 & 45 & 0,004077916 & 0,571877182 \\
\hline
\end{tabular}

1. Grupo; 2. Período. *significância para $p<0,05$.

Tabela 21 - Resultados da comparação entre grupos. Teste de Tukey para o ST

\begin{tabular}{rrrrrr}
\hline & & $\{1\}$ & $\{2\}$ & $\{3\}$ \\
\hline 1 & $\ldots$ & $\{1\}$ &, 2369444 &, 1673000 &, 1638778 \\
2 & $\ldots$ & $\{2\}$ & 0,005830884 & 0,005830884 & $\mathbf{0 , 0 0 3 7 3 6 5 5 *}$ \\
3 & $\ldots$ & $\{3\}$ & 0,003736556 & 0,985930562 & 0,985930562 \\
\hline
\end{tabular}

1.OS; 2.BI; 3.BO. *significância para $\mathrm{p}<0,05$

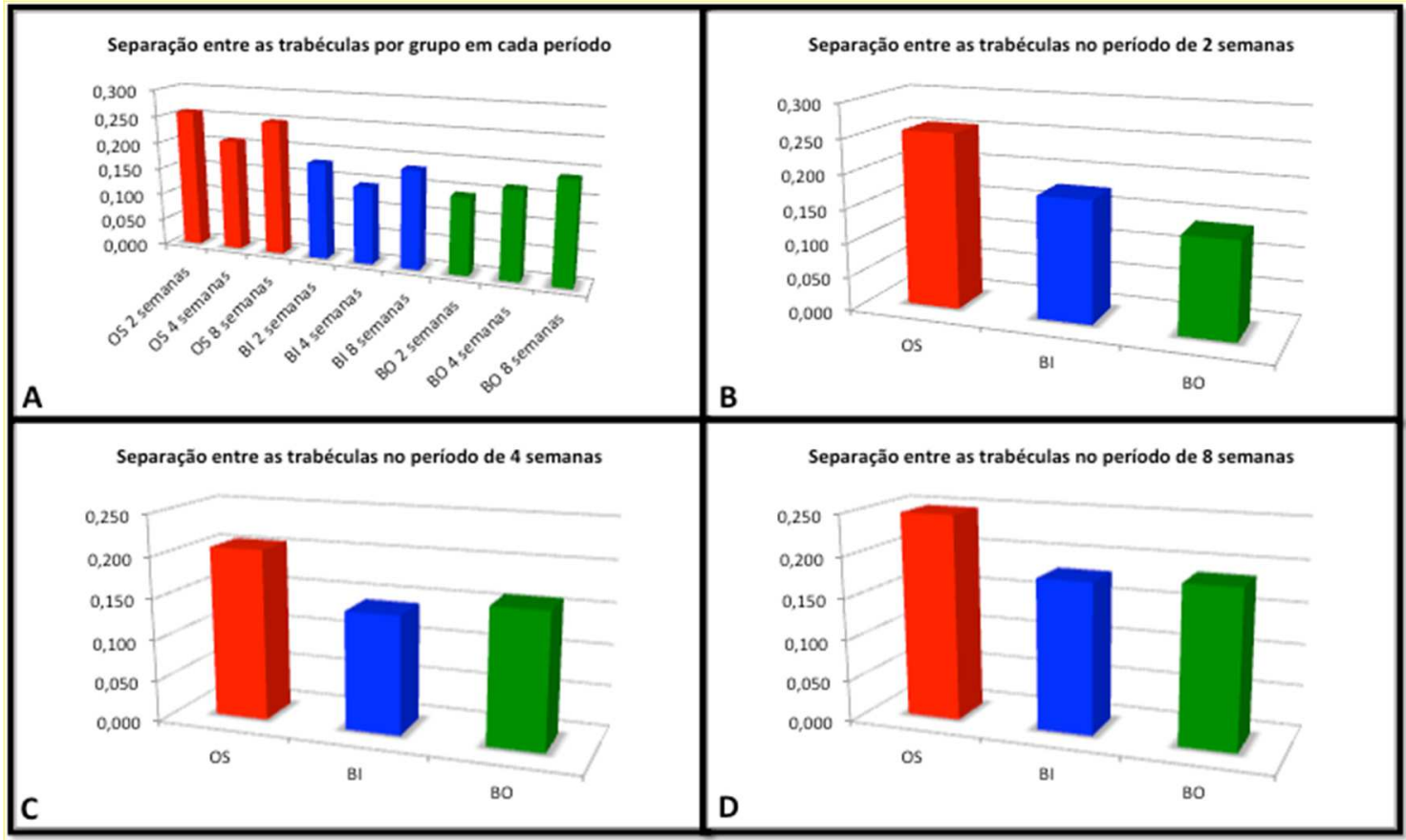

Figura 55 - Gráficos ilustrativos dos resultados da ST em mm. A. Evolução da ST ao longo do tempo, de cada grupo. B. ST de cada grupo no período de 2 semanas. C. ST de cada grupo no período de 4 semanas. D. ST de cada grupo no período de 8 semanas. OS: OsteoScaf ${ }^{\mathrm{TM}}$, BI: Bio-Oss ${ }^{\circledR}, \mathrm{BO}$ : BoneCeramic ${ }^{\circledR}$ 



\subsection{Análises microscópicas}

Para a descrição dos resultados microscópicos, os grupos foram abreviados da seguinte forma: OsteoScaf ${ }^{\mathrm{TM}}$ (BoneTec Corp - TRT, Toronto, Canadá) (OS), Bio-Oss® (Geistlich Biomaterials, Wolhusen, CH, Suíça) (BI), BoneCeramic ${ }^{\circledR}$ (Instituto Straumann AG, Basel, Suíça) (BO) e osso autógeno (AU).

\subsubsection{Análise qualitativa da microscopia eletrônica de varredura (SEM)}

A avaliação através da microscopia eletrônica de varredura (SEM), por retroespalhamento de elétrons, foi realizada para confirmar com acurácia a presença de neoformação óssea, principalmente, do grupo OS, o qual demonstrou dificuldades na avaliação microtomográfica no período de 2 semanas, e para analisar a íntima relação da interface osso-biomateral. Diferente das imagens obtidas no MicroCT, a diferença entre novo osso e as partículas de OS foi nitidamente evidente (Figuras 56-58). Porém, no grupo AU, a diferença entre o osso originalmente enxertado e o neoformado foi um pouco difícil. Foi possível observar discretas áreas mais hiperdensas sugerindo osso enxertado (Figuras 59-61).

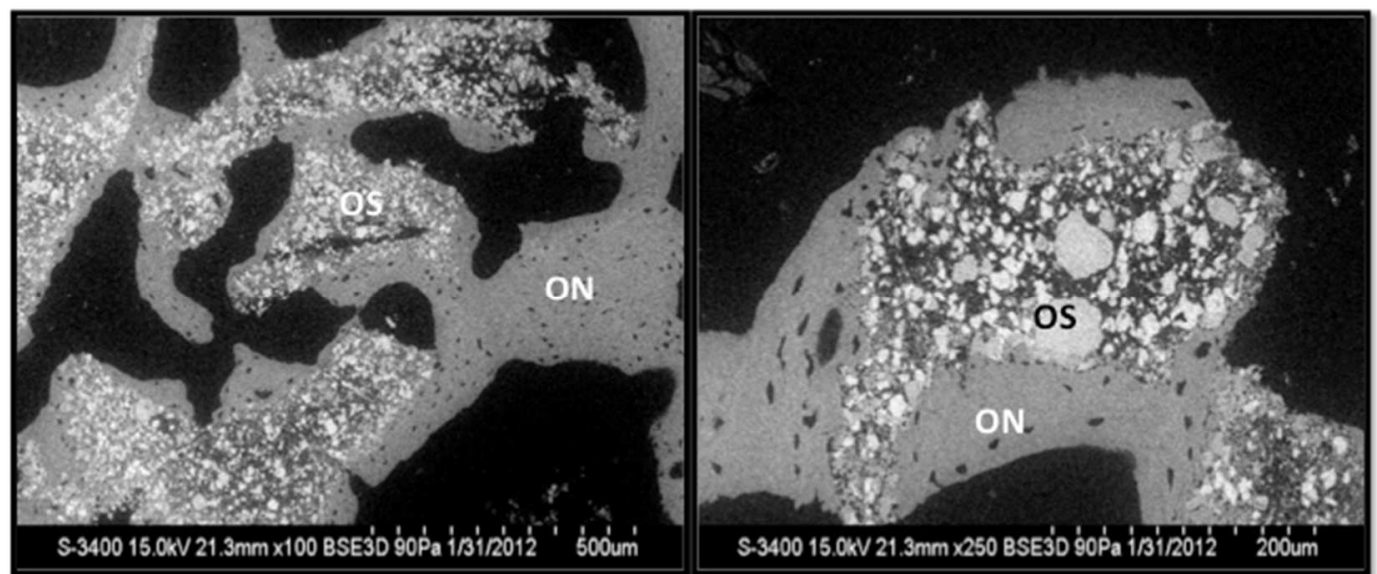

Figura 56 - OsteoScaf ${ }^{\mathrm{TM}}$, período de 8 semanas. Osso neoformado $(\mathrm{ON})$ circundando as áreas do biomaterial em degradação (OS). As partículas constituídas por OsteoScaf ${ }^{\mathrm{TM}}$ foram reabsorvidas e perderam seu formato original, restando algumas partículas hiperdensas de fosfato de cálcio em menor quantidade comparada aos períodos anteriores. Todo o biomaterial foi circundado por tecido ósseo e houve conexão entre as trabéculas neoformadas 



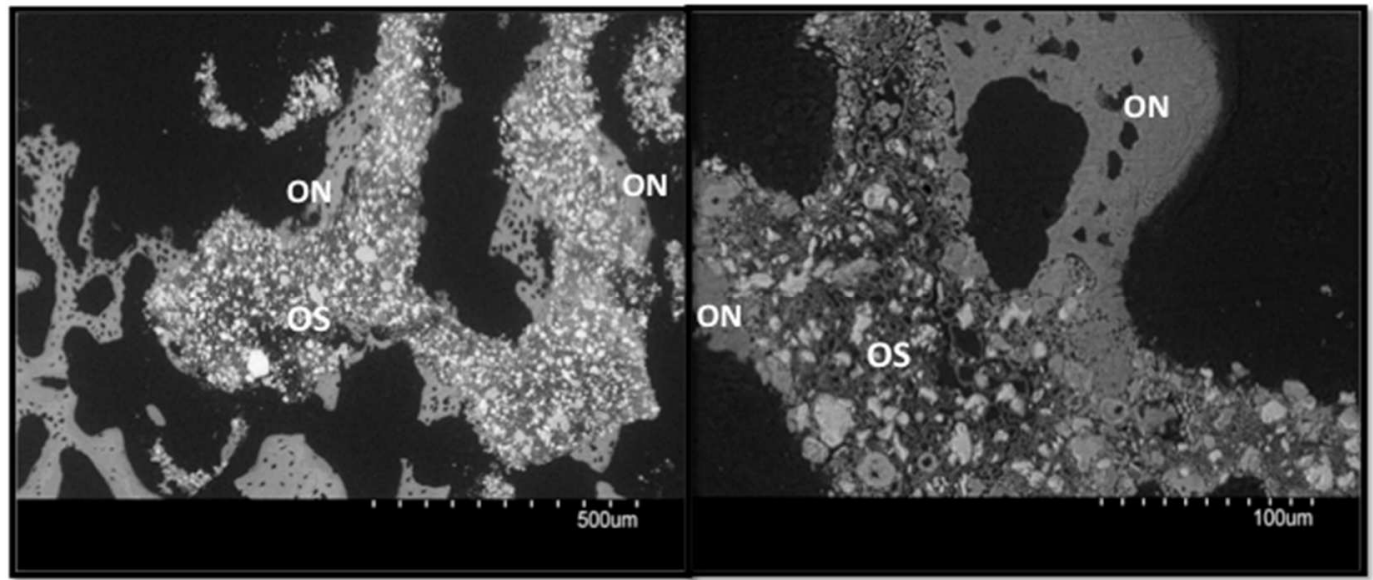

Figura 57 - OsteoScaf ${ }^{\mathrm{TM}}$, período de 4 semanas. Menor quantidade de neoformação óssea (ON) e biodegradação do material (OS) quando comparada ao período de 8 semanas

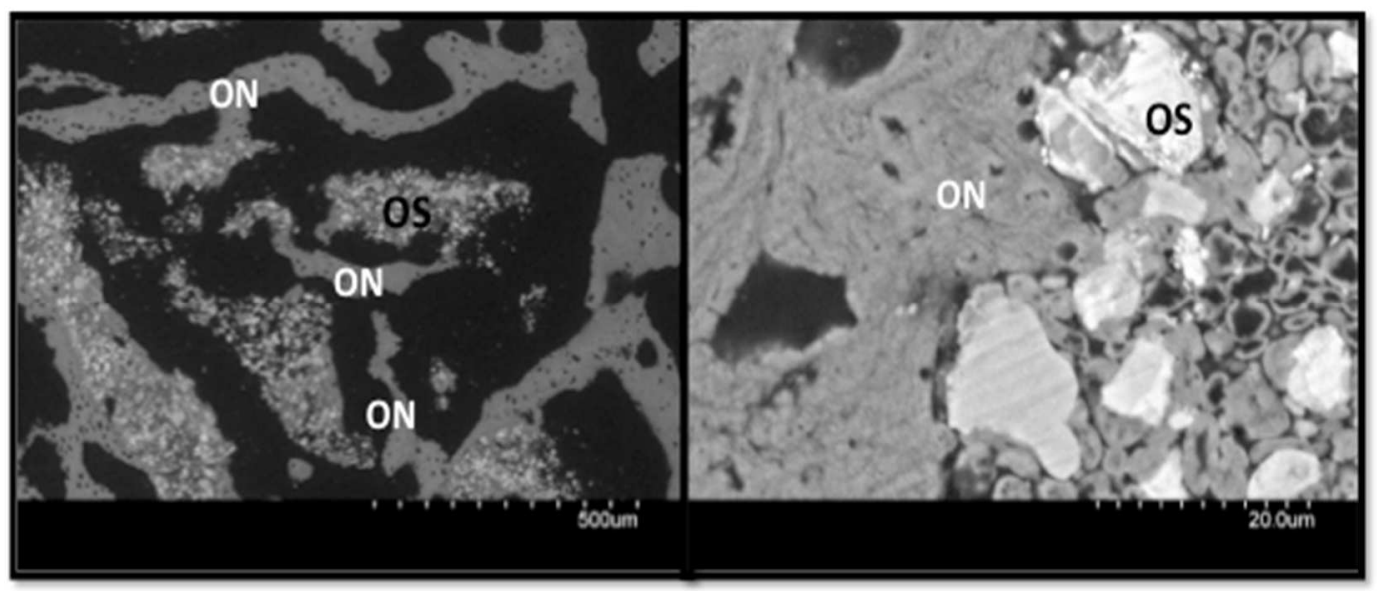

Figura 58 - OsteoScaf ${ }^{\mathrm{TM}}$, período de 2 semanas. Menor quantidade de neoformação óssea (ON) e biodegradação do material (OS) comparada aos outros períodos

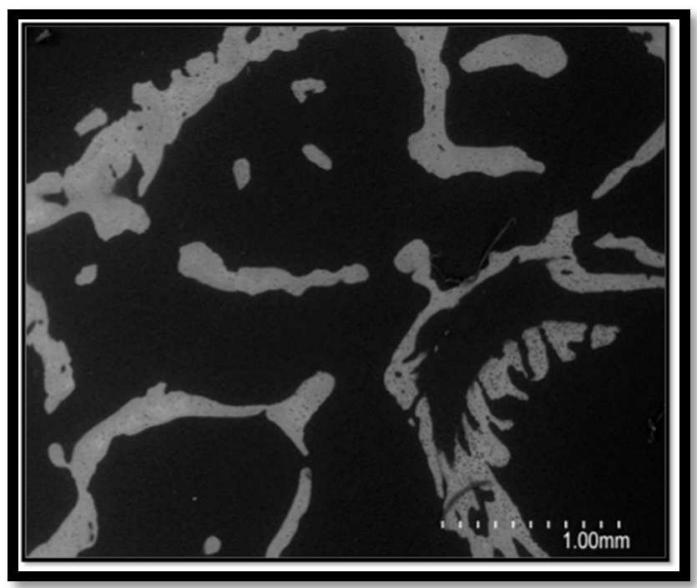

Figura 59 - Osso autógeno, período de 8 semanas. Trabéculas ósseas apresentaram aspecto de remodelação e os espaços entre as mesmas foram maiores, indicando reabsorção 



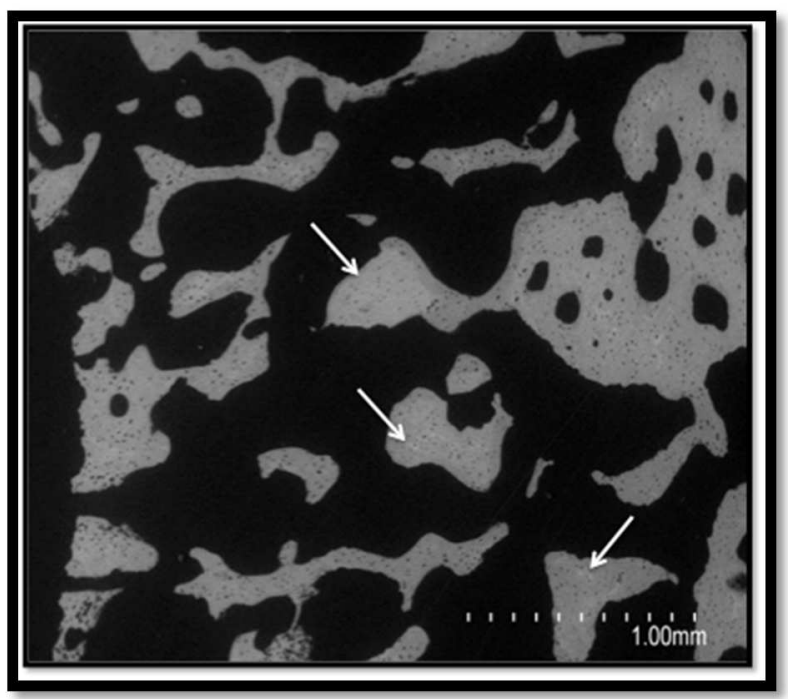

Figura 60 - Osso autógeno, período de 4 semanas. Setas indicam áreas levemente mais hiperdensas correspondentes às partículas enxertadas

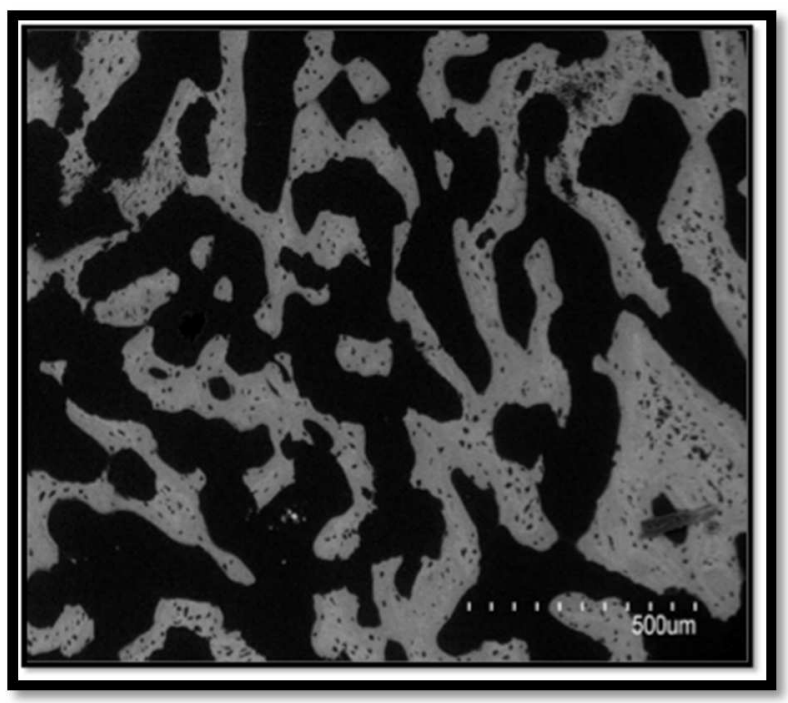

Figura 61 - Osso autógeno, período de 2 semanas. Várias trabéculas ósseas interconectadas e maior proximidade entre as mesmas, demonstrando período de maior volume ósseo

Em todos os grupos dos biomateriais, foi observada neoformação óssea com 2, 4 e 8 semanas e todos eles apresentaram aumento de volume ósseo com o tempo. No período de 2 semanas, havia novo osso circundando as partículas de todos os biomateriais. Em todos os períodos, o grupo BI apresentou maior neoformação óssea comparada aos outros grupos (Figuras 62-64). Além disso, apresentou maior número de trabéculas interconectadas entre si, seguida do OS (Figuras 56-58) e BO (Figuras 65-67), respectivamente, os quais foram muito similares na quantidade de neoformação óssea. Apesar dessa semelhança, houve bastante similaridade no formato das novas trabéculas entre os grupos BI e OS com o tempo (Figuras 56-58, 62-64). 



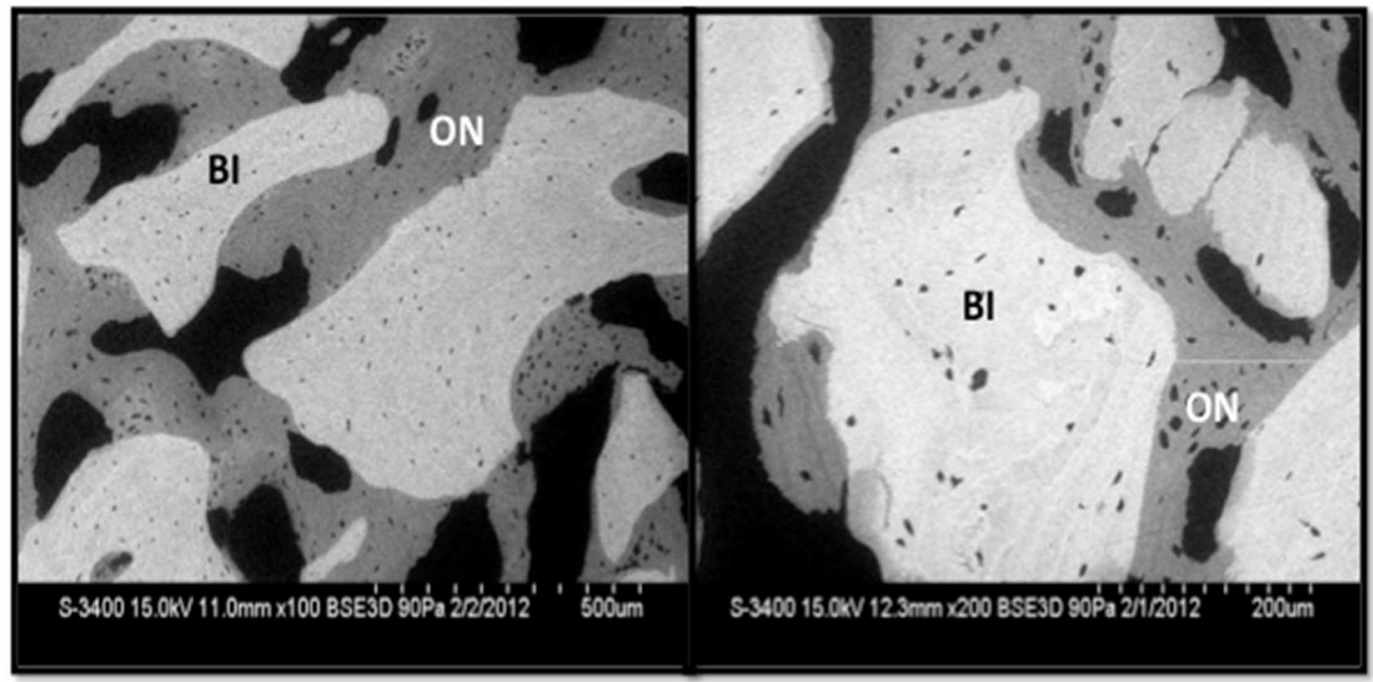

Figura 62 - Bio-Oss ${ }^{\circledR}$, período de 8 semanas. Partículas do biomaterial (BI) circundadas por maior volume ósseo $(\mathrm{ON})$ comparado aos outros grupos

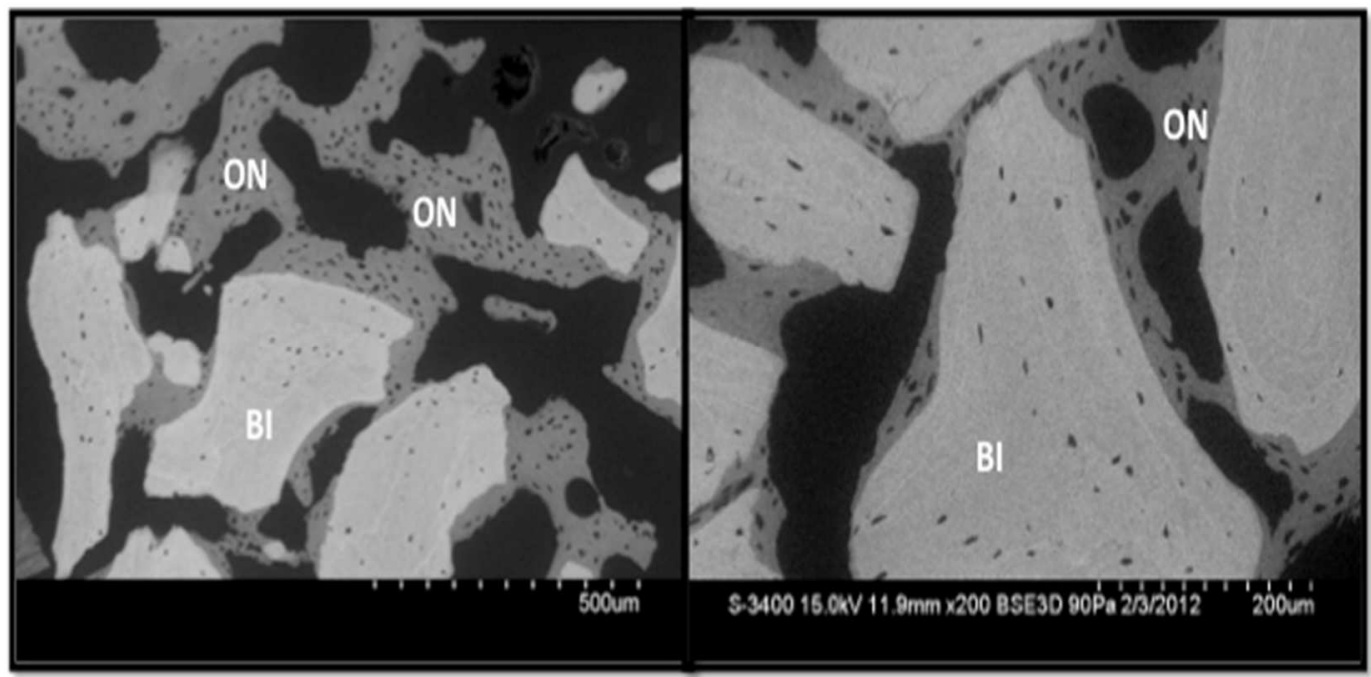

Figura 63 - Bio-Oss $®$, período de 4 semanas. Osso neoformado $(\mathrm{ON})$ circundando as partículas do biomaterial (BI)

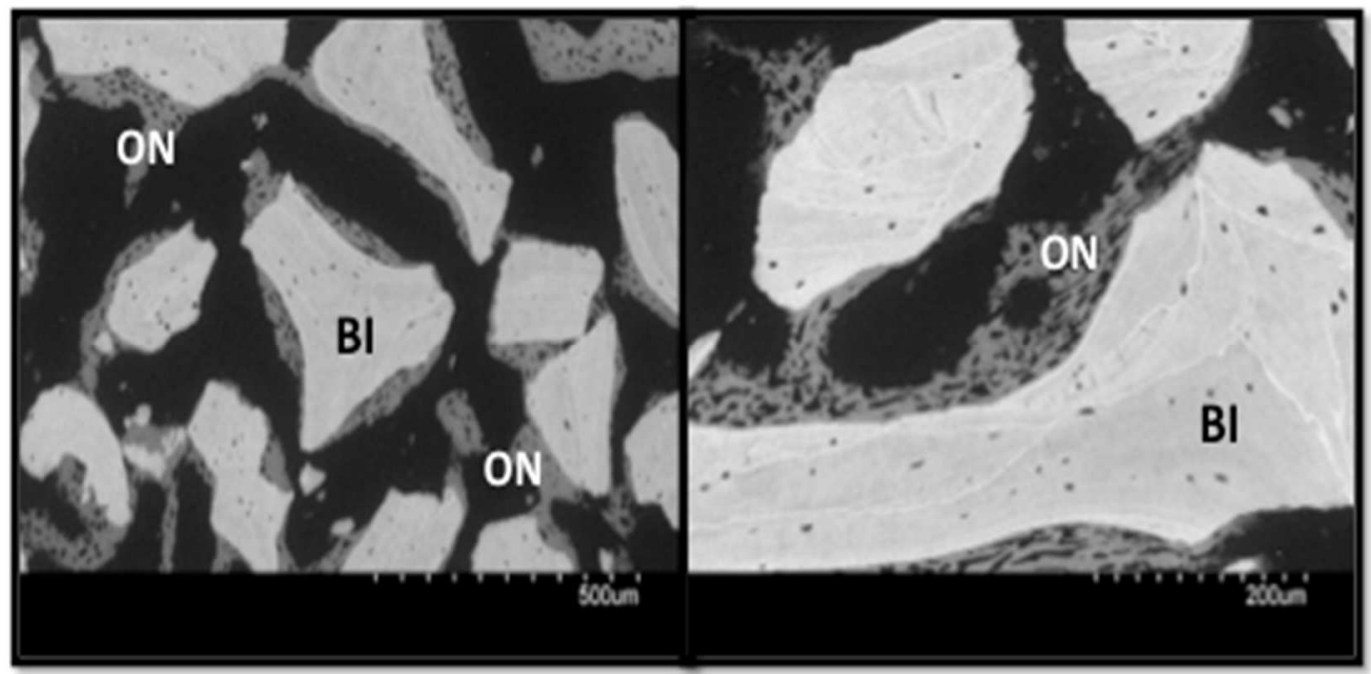

Figura 64 - Bio-Oss $®$, período de 2 semanas. Osso neoformado $(\mathrm{ON})$ circundando as partículas do biomaterial (BI). Período de menor volume ósseo neoformado 



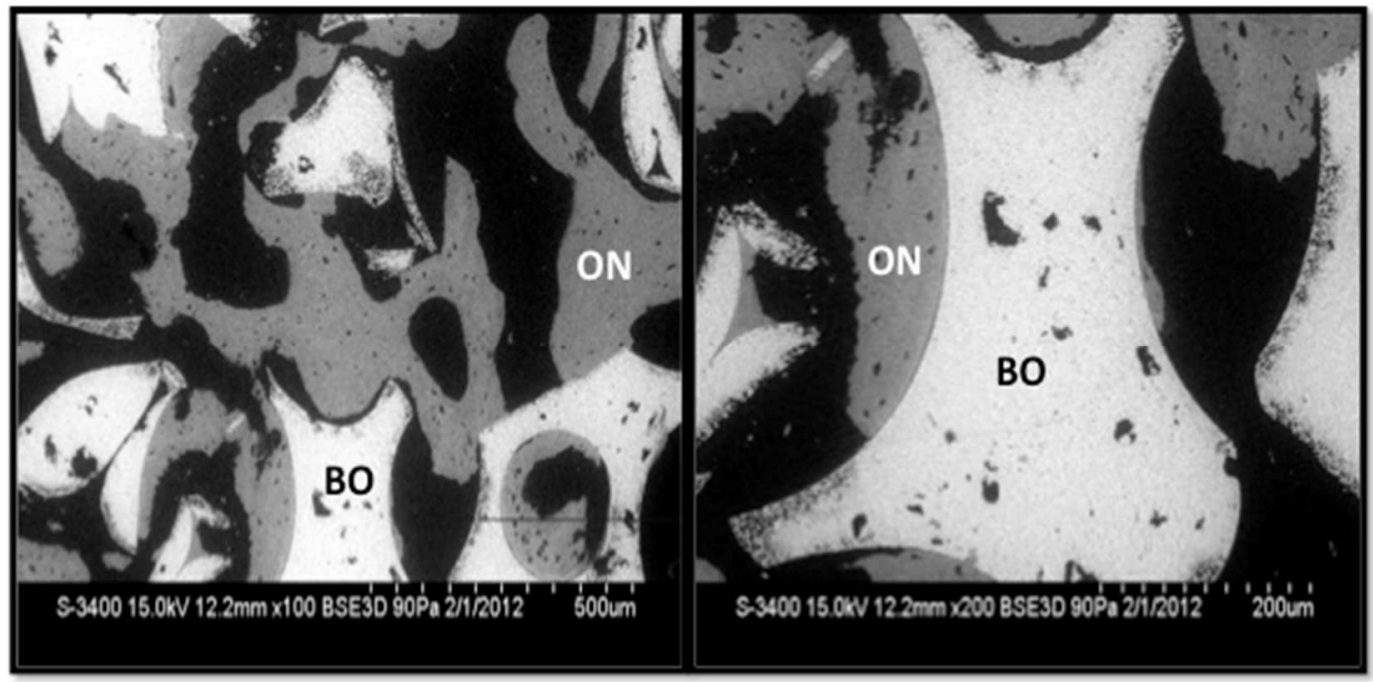

Figura 65 - BoneCeramic $\AA$, período de 8 semanas. Osso neoformado $(\mathrm{ON})$ circundando as partículas do biomaterial (BO). Período de maior volume ósseo neoformado

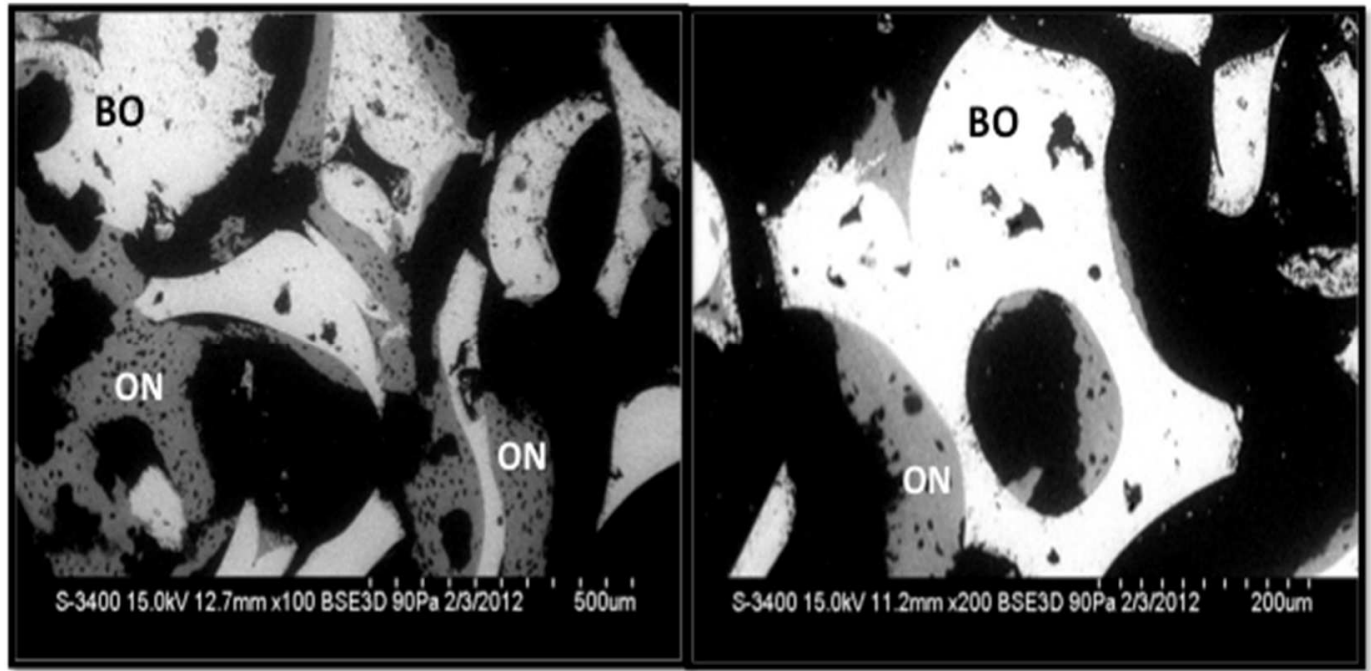

Figura 66 - BoneCeramic ${ }^{\circledR}$, período de 4 semanas. Osso neoformado (ON) circundando as partículas do biomaterial $(\mathrm{BO})$

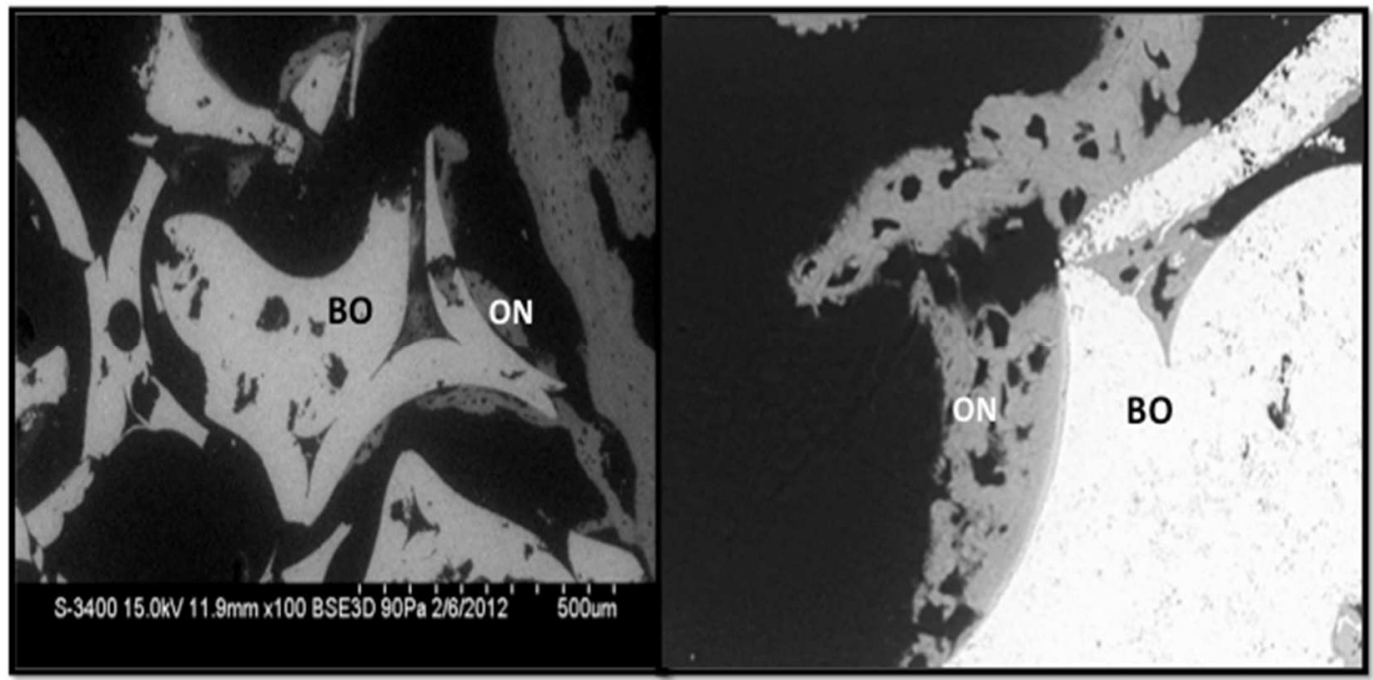

Figura 67 - BoneCeramic ${ }^{\circledR}$, período de 2 semanas. Osso neoformado (ON) circundando as partículas do biomaterial (BO). Período de menor volume ósseo neoformado 

A avaliação por microscopia de varredura também forneceu informações sobre o formato e a degradação dos biomateriais utilizados neste estudo. Embora as partículas apresentassem tamanhos similares entre os grupos, a geometria de cada biomaterial se mostrou diferente. Foi possível observar, nitidamente, a diferença entre cada biomaterial. Diferente dos grupos BO e BI, o grupo OS apresentou um formato geométrico representado por partículas irregulares. Os demais grupos apresentaram partículas inteiras bem definidas, demonstrando ser o OS o único biomaterial biodegradável (Figuras 56-58).

Em relação ao tamanho, o grupo $\mathrm{BI}$ apresentou as maiores partículas nas imagens de SEM (Figuras 62-64), seguida pelos grupos BO (Figuras 65-67) e OS (Figuras 56-58), respectivamente, diferente da condição inicial, prévia ao procedimento cirúrgico. A razão, novamente, foi a biodegradação do grupo OS. O osso neoformado foi encontrado circundando as partículas de OS e no espaço entre as partículas degradadas (Figuras 56-58). O grupo BI (Figuras 62-64) apresentou as suas partículas íntegras, com formato mais regular que as partículas do grupo BO (Figuras 65-67), as quais assumiram moderadas curvas em sua geometria irregular. Além disso, diferente do grupo BI, BO mostrou muitas porosidades em sua superfície (Figuras 65-67). 



\subsubsection{Microscopia óptica}

\subsubsection{Análise qualitativa}

Em todos os grupos, a membrana sinusal (MS) manteve a morfologia cuboidal do epitélio estratificado ciliado, apresentando glândulas serosas (GL) no tecido submucoso e muitos vasos sanguíneos (VS) abaixo da mesma (Figura 68, 69).

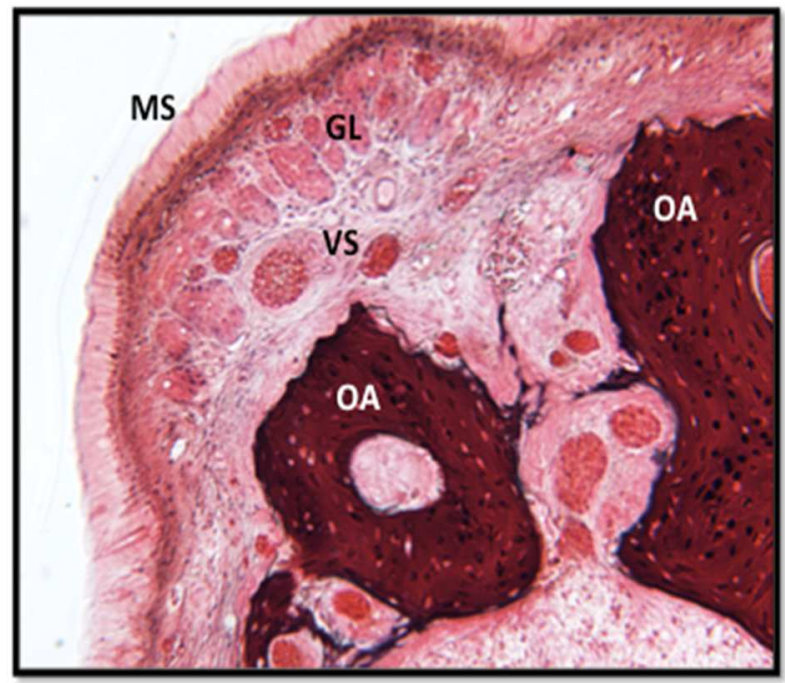

Figura 68 - Aspecto de normalidade da membrana sinusal (MS) num espécime correspondente ao grupo osso autógeno (OA), período de 8 semanas. Presença de glândulas serosas (GL) abaixo da região da MS e vasos sanguíneos (VS) em permeio ao enxerto. 10X (HE)

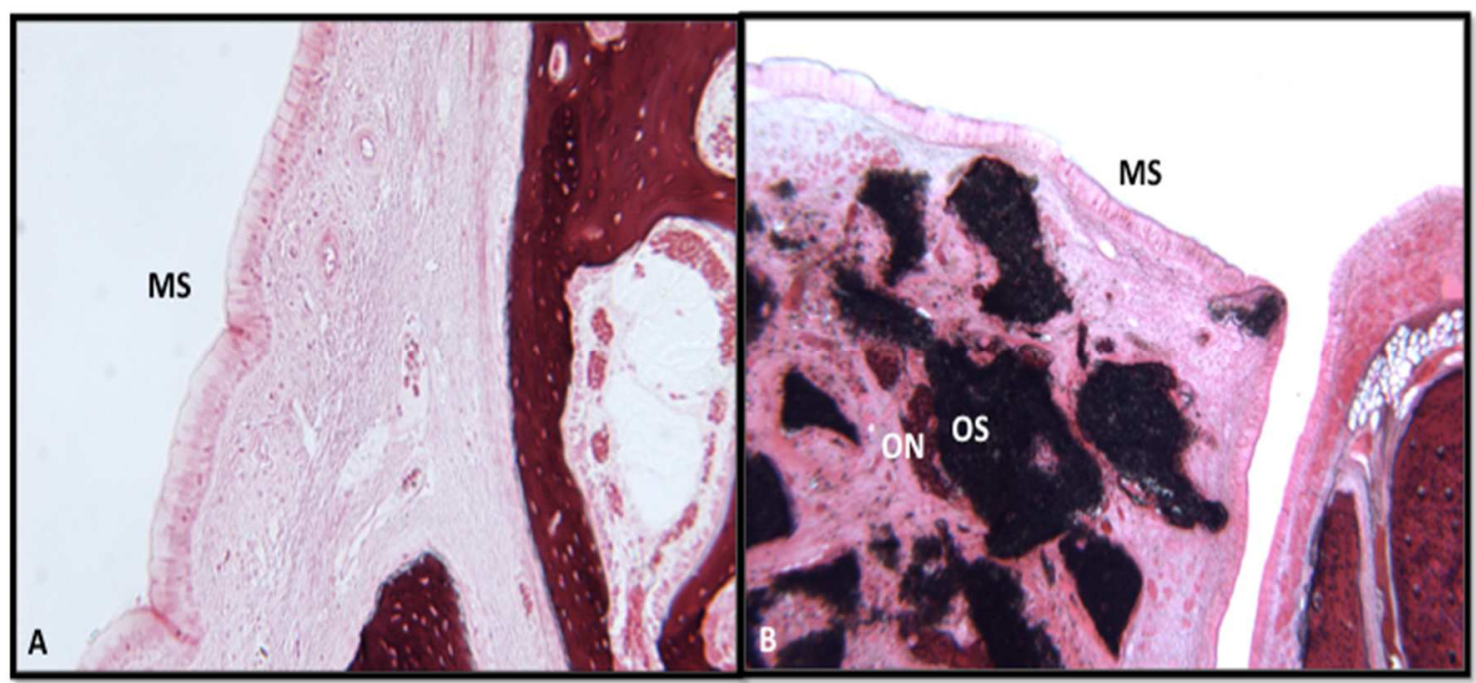

Figura 69 - Outras imagens da MS demonstrando sua integridade após o enxerto com osso autógeno (A) 10X e OsteoScaf ${ }^{\mathrm{TM}}$ no período de 2 semanas (OS) (B) $4 \mathrm{X}(\mathrm{HE})$ 

No período de 2 semanas, não foi notada a presença de infiltrado inflamatório em nenhum espécime analisado. O osso neoformado (ON) foi observado na periferia da área do procedimento de levantamento de seio maxilar, principalmente próximo à janela cirúrgica ou em contato com as paredes ósseas do seio maxilar (Figura 70).

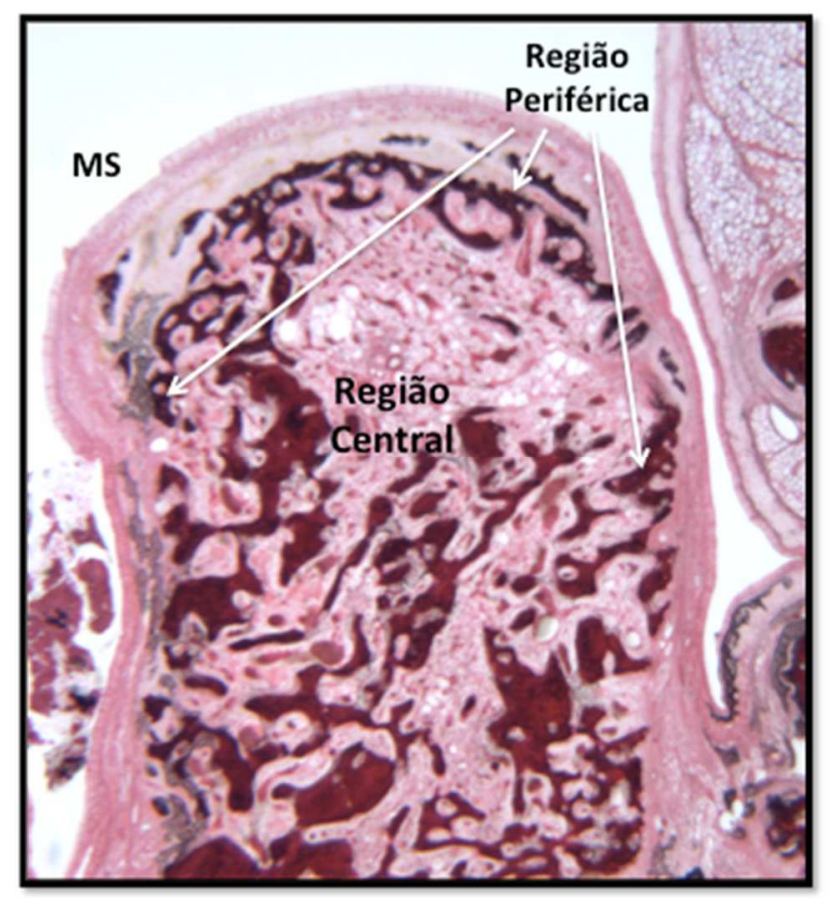

Figura 70 - Imagem ilustrativa da área de um seio maxilar após enxerto com osso autógeno, no período de 8 semanas. A neoformação óssea se deu da periferia para o centro. 1,6X (HE)

No período de 2 semanas, a presença de neoformação óssea nas áreas centrais variou entre os grupos, mas foi bem menor comparada aos outros períodos. As partículas dos biomateriais se encontraram circundadas por tecido conjuntivo fibroso, porém, em alguns espécimes, foi encontrado ON circundando-as, principalmente, no grupo BI (Figura 71). Nesse período, o osso autógeno revelou maior quantidade de ON comparado aos outros grupos, além de maior quantidade de trabéculas ósseas, enquanto os grupos experimentais apresentaram mais partículas, correspondentes aos biomateriais. 



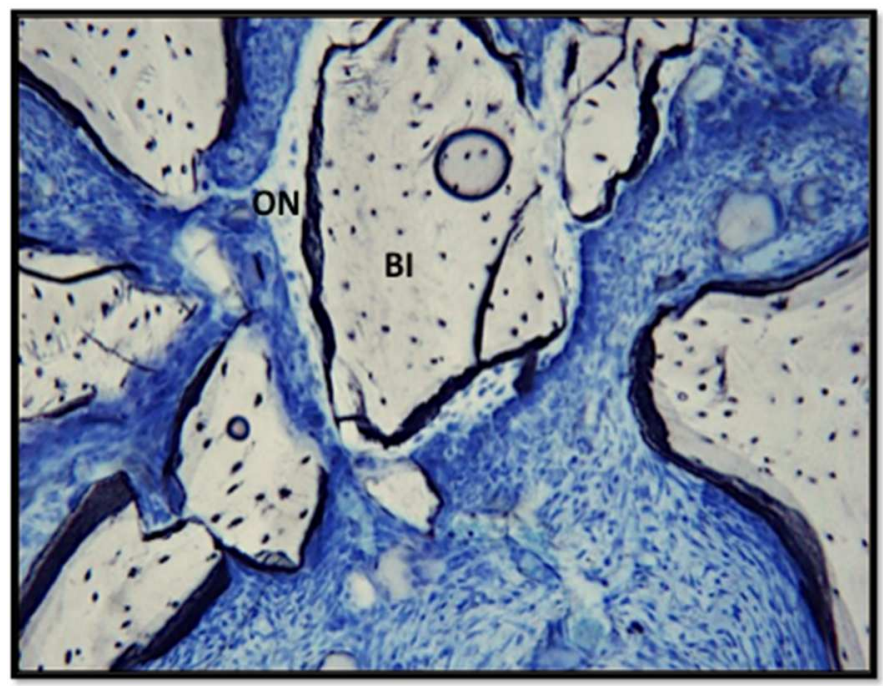

Figura 71 - Bio-Oss ${ }^{\circledR}$, período de 2 semanas. Presença de osso neoformado (ON) circundando as partículas (BI) na região central. Coloração: Azul de Toluidina (AT) $10 \mathrm{X}$

O grupo BI foi o grupo experimental que obteve maior formação óssea circundando suas partículas (Figuras 71, 72, 73). Os grupos OS (Figuras 74) e BO (Figura 75), qualitativamente, mostraram-se semelhantes quando esse comportamento foi observado.

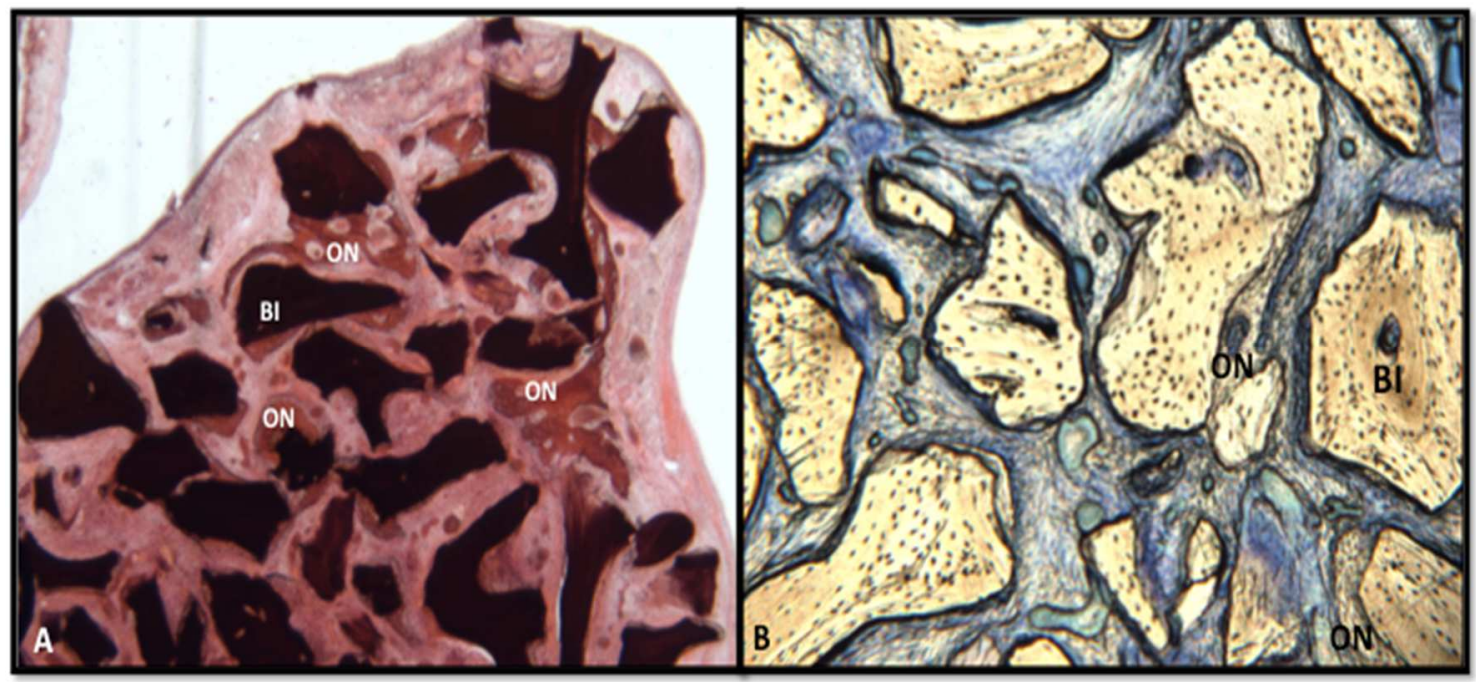

Figura 72 - Bio-Oss ${ }^{\circledR}$, período de 4 semanas. (A) Presença de osso neoformado (ON) circundando as partículas (BI) 4X (HE). As áreas centrais (B) demonstraram menor quantidade de ON comparado ao período de 8 semanas. 10X (AT) 



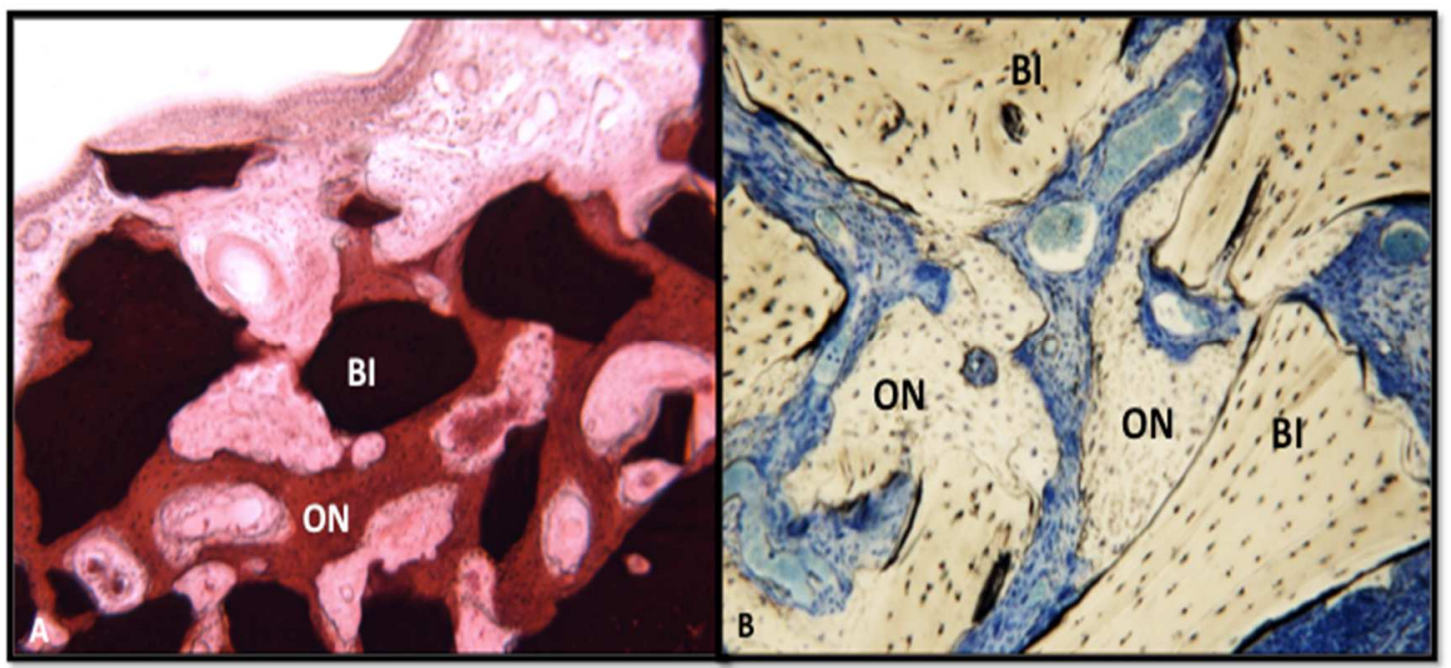

Figura 73 - Bio-Oss $®$, período de 8 semanas. Maior presença de osso neoformado (ON) circundando as partículas (BI) comparado aos outros períodos e grupos. A. 4X (HE); B. 10X (AT)

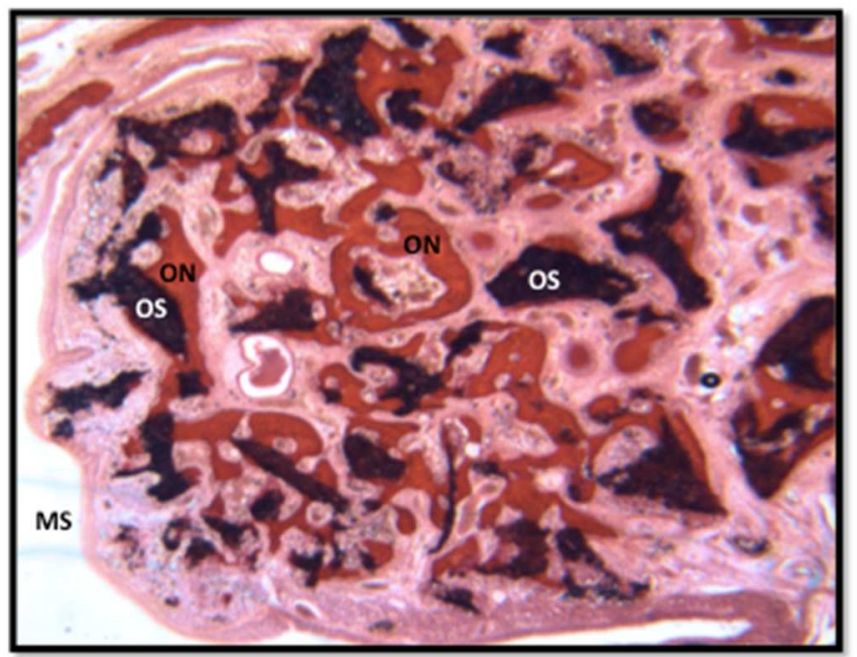

Figura 74 - OsteoScaf ${ }^{\mathrm{TM}}$, período de 8 semanas. Menor quantidade de partículas (OS), as quais se apresentaram em processo de degradação e com $(\mathrm{ON})$ circundando-as. $\mathrm{O}$ formato das trabéculas se assemelha ao grupo BioOss®. 4X (HE)

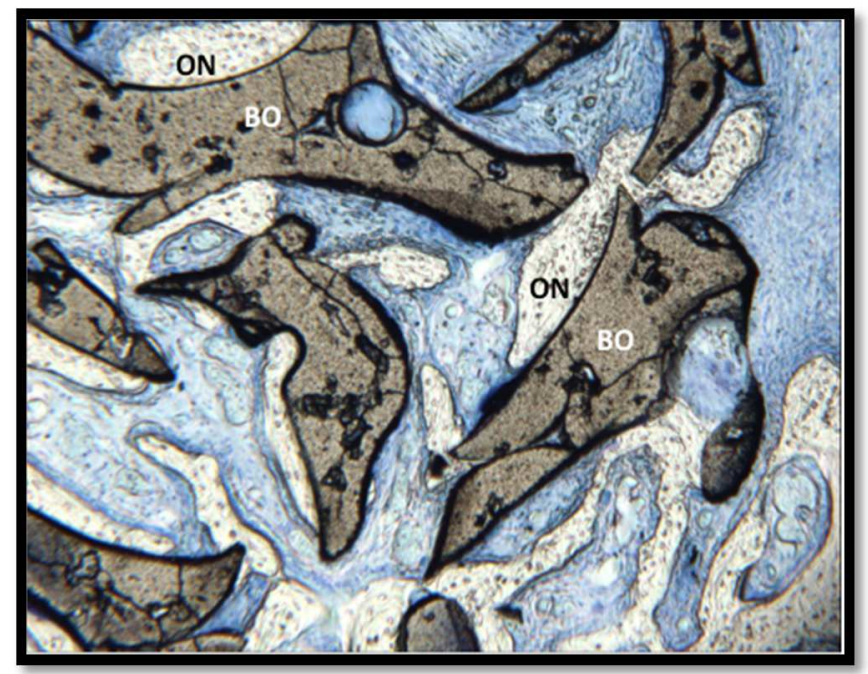

Figura 75 - BoneCeramic ${ }^{\circledR}$, período de 8 semanas. Maior quantidade de $(\mathrm{ON})$ circundando as partículas (BO) comparado aos outros períodos. Presença de partículas inteiras com algumas microfraturas e porosidades na superfície. 10X (AT) 

O único grupo biodegradável foi o OS, que mostrou osso neoformado interposto nas partículas de fosfato de cálcio (Figura 76). Os grupos BO (Figuras 77, 78) e BI (Figuras 7173) apresentaram morfologia regular, ausência de degradação e muita semelhança com o aspecto macroscópico.

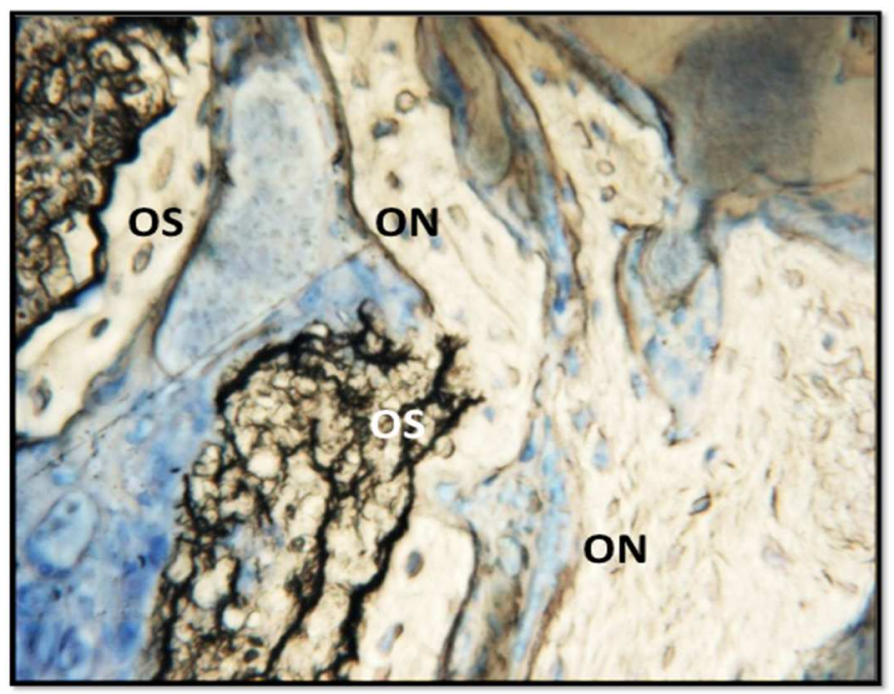

Figura 76 - OsteoScaf ${ }^{\mathrm{TM}}$, período de 8 semanas. Partículas (OS) bastante biodegradadas e sendo substituídas por ON. 10X (AT)

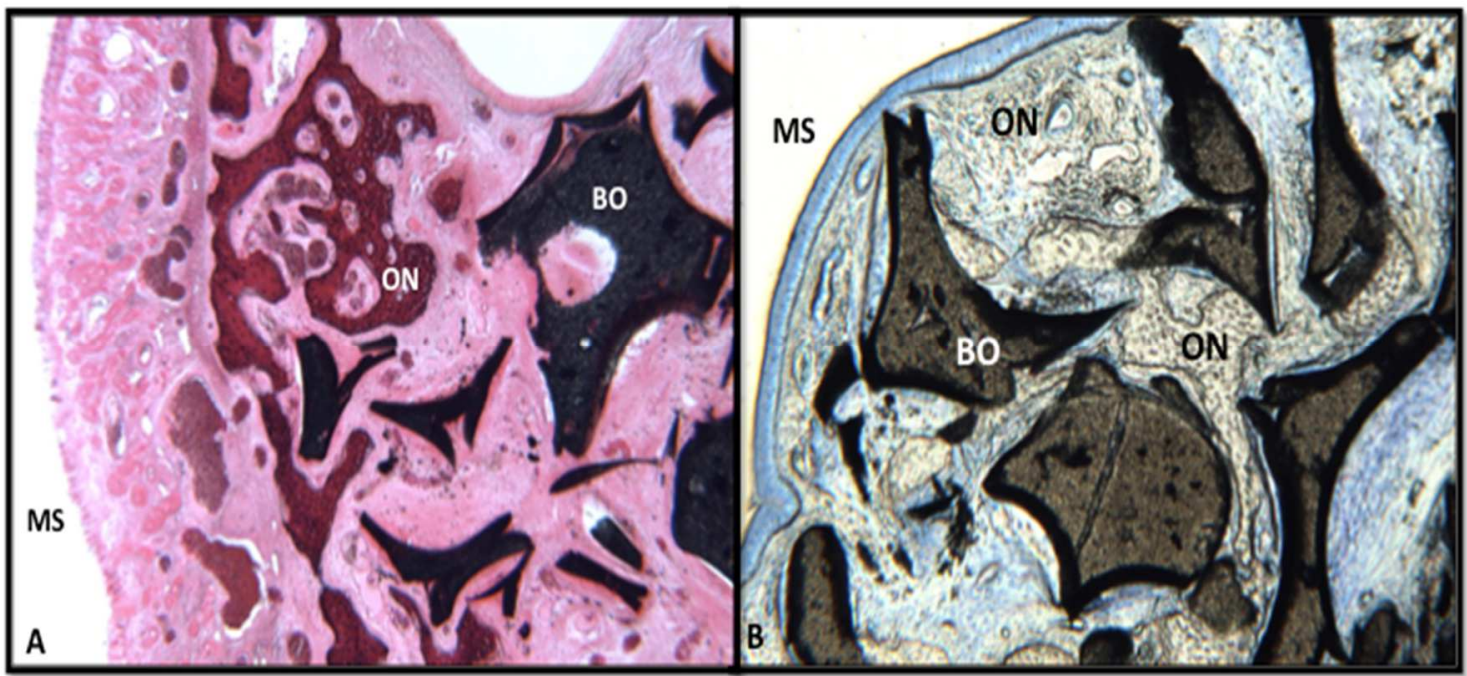

Figura 77 - BoneCeramic®, período de 8 semanas. Integridade da MS e sua relação com as partículas (BO). Partículas (BO) permaneceram com seu formato original demonstrando ausência de degradação com 8 semanas. A. $4 \mathrm{X}(\mathrm{HE}) ;$ B. $4 \mathrm{X}(\mathrm{AT})$ 



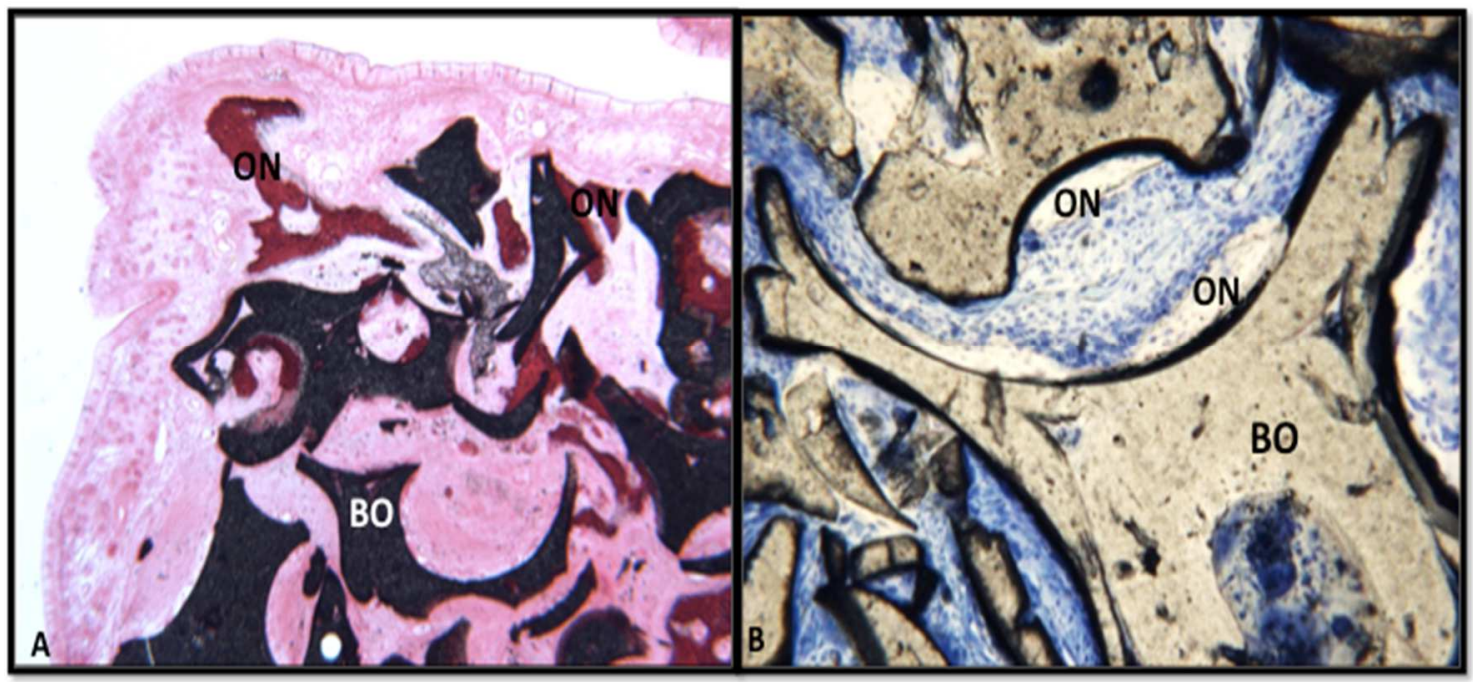

Figura 78 - BoneCeramic®, período de 4 semanas. Presença de ON circundando as partículas (BO) com maior frequência nas áreas periféricas. A. 4X (HE); B. 10X (AT)

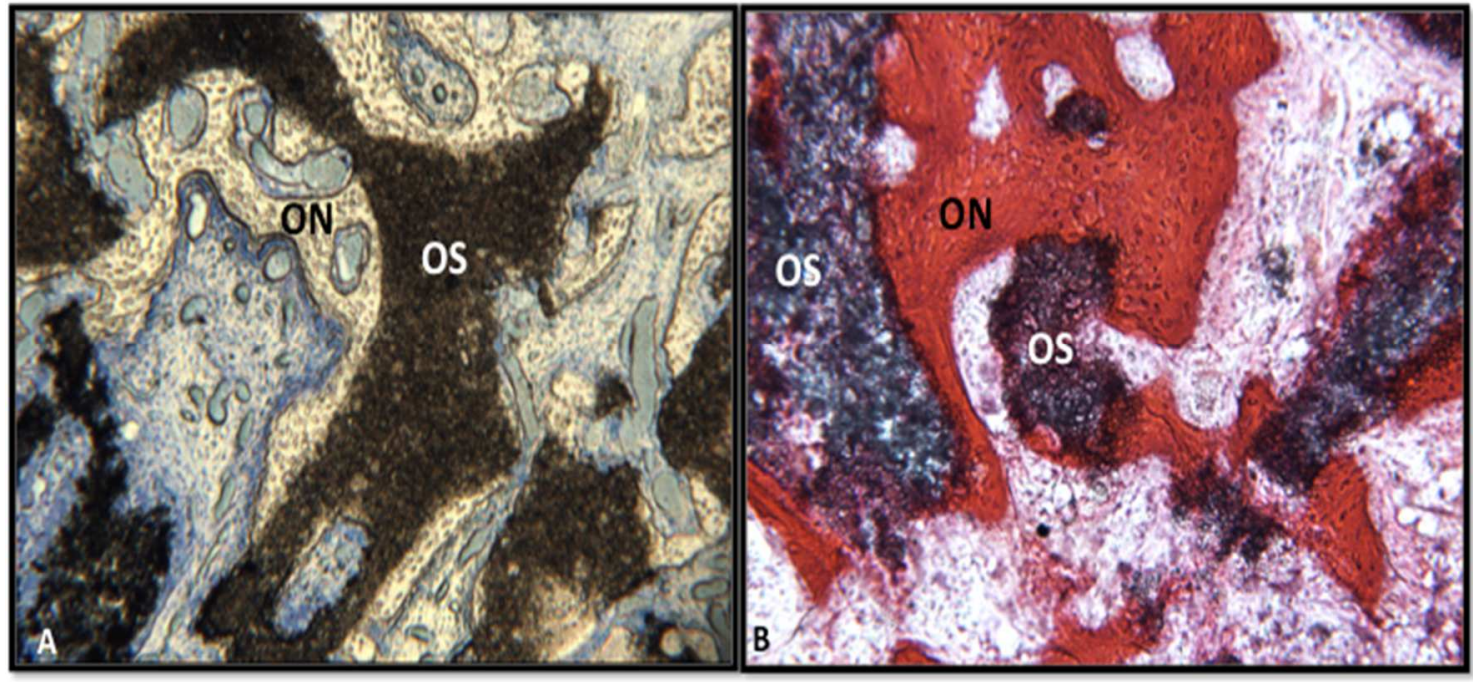

Figura 79 - OsteoScaf ${ }^{\mathrm{TM}}$, período de 8 semanas. A. Detalhe de partículas (OS) ainda não totalmente biodegradadas circundadas em várias regiões por ON. 10X (AT), B. 10X (HE)

No período de 4 semanas, não foi notada a presença de infiltrado inflamatório em nenhum espécime analisado. Houve maior neoformação óssea em todos os grupos, comparada ao período anterior, com exceção ao osso autógeno que se manteve com um volume muito similar ao período de 2 semanas. A intensidade de neoformação óssea na região central também foi maior comparada ao período de 2 semanas. Somente o grupo OS apresentou biodegradação, sendo maior do que com 2 semanas (Figura 80, 81). 



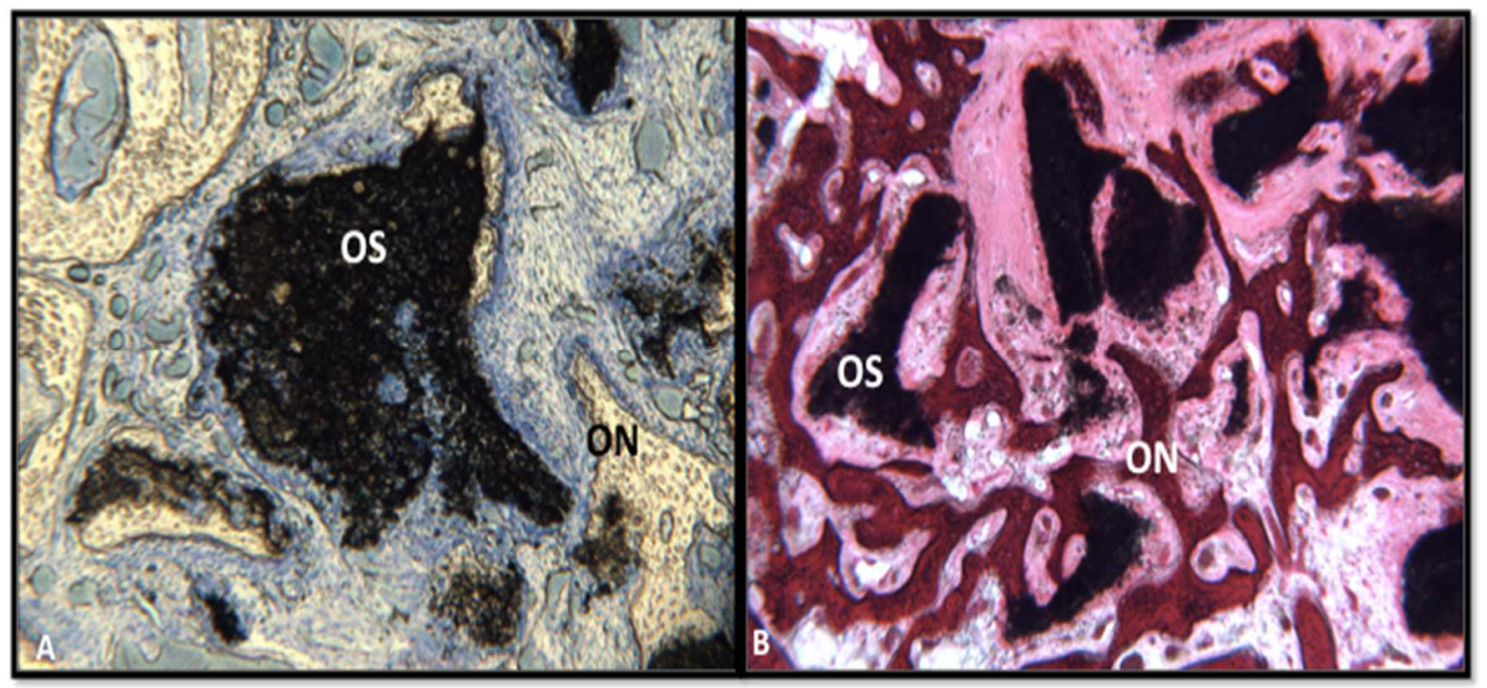

Figura 80 - OsteoScaf ${ }^{\mathrm{TM}}$, período de 4 semanas. A. As partículas (OS) apresentaram biodegradação e menor quantidade de ON circundando-as comparada ao período de 8 semanas 10X (AT); B. 4X (HE)

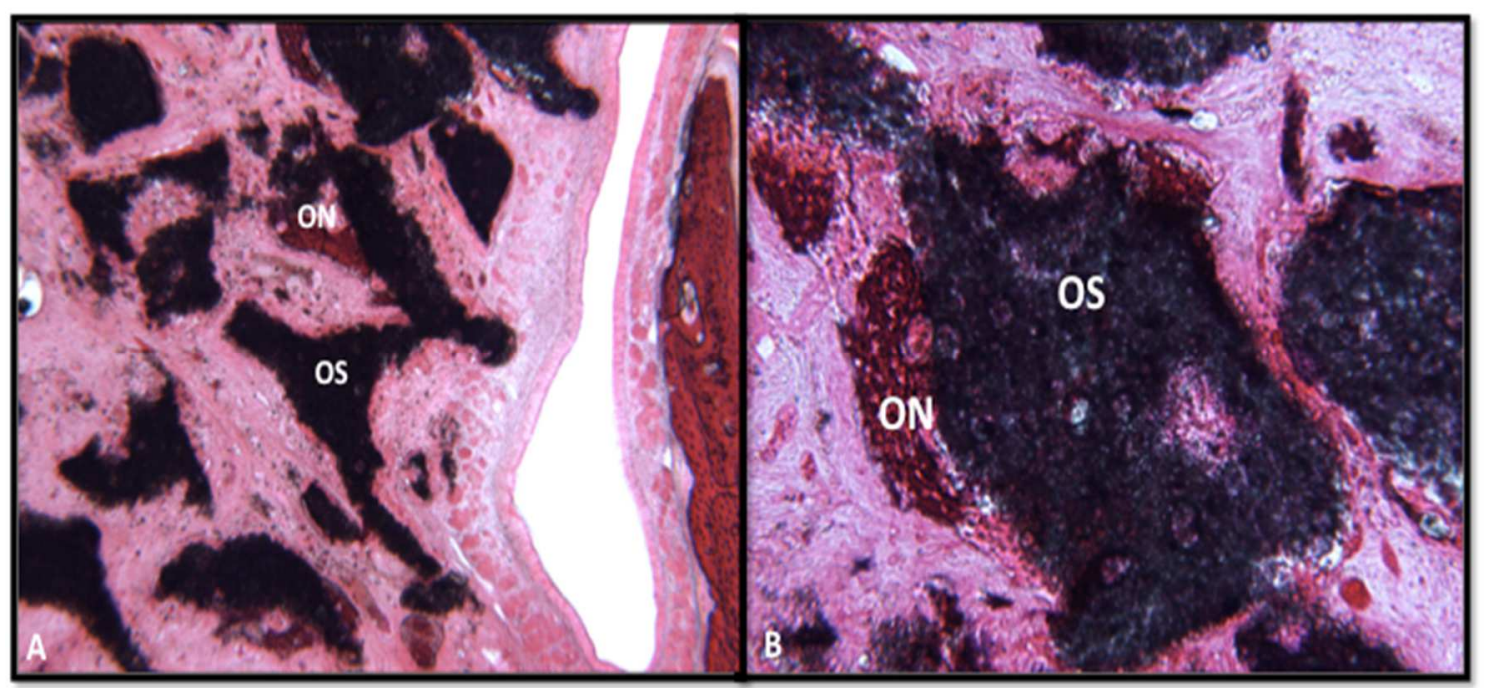

Figura 81 - OsteoScaf ${ }^{\mathrm{TM}}$, período de 2 semanas. Maior quantidade de partículas (OS) e menor de ON comparado aos outros períodos A. 4X (HE) e B. 10X (HE)

No período de 8 semanas, as partículas dos biomateriais de todos os grupos mostraram-se bem mais circundadas por osso recém-formado, revelando maior volume ósseo obtido. Porém o grupo AU apresentou uma reabsorção óssea significante, representada por uma menor quantidade de volume ósseo comparada aos períodos anteriores. Além disso, foram encontradas regiões vazias e muitas células de gordura preenchendo os espaços medulares (Figura 82). 



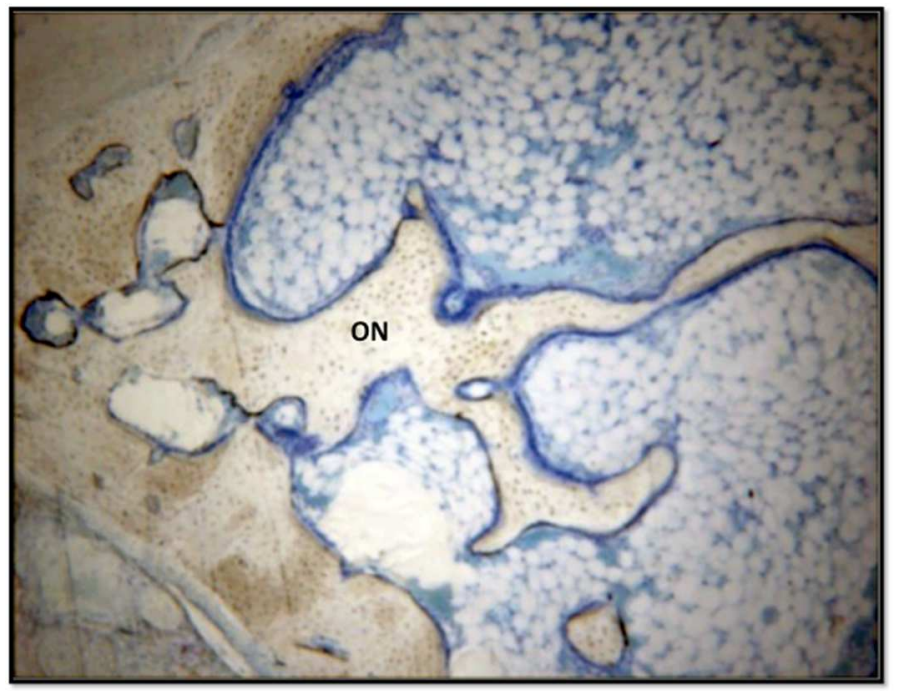

Figura 82 - Osso autógeno, período de 8 semanas. Grande quantidade de células de gordura preenchendo os espaços vazios, após reabsorção óssea. 4X (AT)

Os grupos OS e BO apresentaram aspecto similar de volume ósseo, embora o OS tenha mostrado morfologia de neoformacão óssea semelhante à do grupo BI, representada por trabéculas conectando diferentes partículas. Diferente dos outros grupos, BO mostrou resposta de células gigantes circundando algumas de suas partículas, mesmo apresentando osso neoformado nas mesmas (Figura 83).

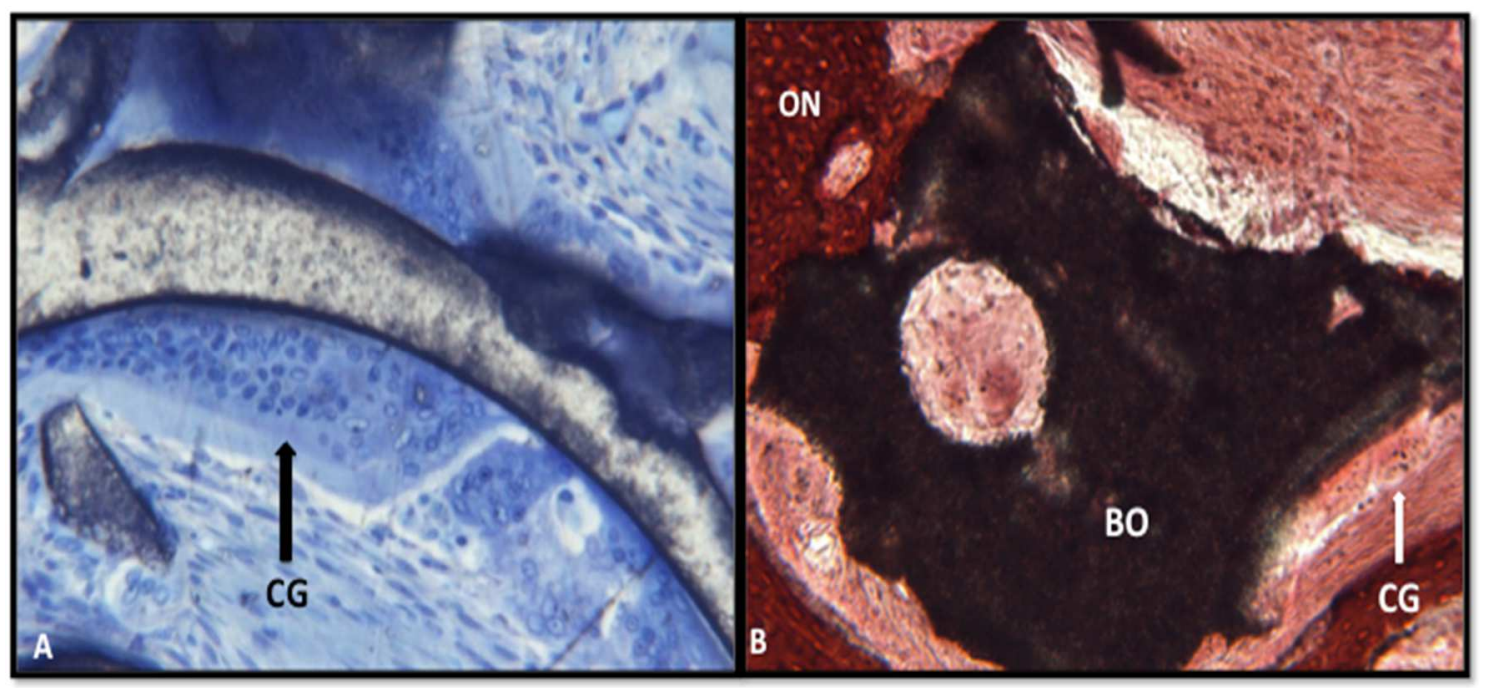

Figura 83 - BoneCeramic $\AA$, período de 8 semanas. Detalhe das células gigantes envolvendo as partículas (BO). A. $10 \mathrm{X}(\mathrm{AT}) ;$ B. $10 \mathrm{X}(\mathrm{HE})$ 



\subsubsection{Análise quantitativa através da microscopia confocal}

O resultado da análise histomorfométrica expresso através da porcentagem da marcação de neoformação óssea realizada pela tetraciclina, alizarina e calceína nas imagens obtidas em microscópio confocal Leica TSS SPE (Mannheim Alemanha) e quantificadas através do software AxionVision 40V 4.82.0 (Carl Zeiss MicroImaging GmbH) foram descritos na forma de tabelas descrevendo a média, desvio-padrão e resultados estatísticos das marcações, após os dados serem analisados entre os grupos, os campos e os períodos empregando-se os testes de variância ANOVA a 3 critérios e teste de Tukey para as variáveis tetraciclina e alizarina e ANOVA a 2 critérios e teste de Tukey para a calceína. Além disso, alguns gráficos foram realizados para melhor compreensão dos resultados, ao longo do tempo. Os campos 1, 2 e 3 correspondem à área mais próxima da janela cirúrgica, região central e região próxima à membrana sinusal, respectivamente.

\subsubsection{Variável tetraciclina}

O marcador ósseo tetraciclina foi observado em todos os grupos e períodos. Não houve diferença entre os grupos e nem entre os campos, porém houve diferença entre os períodos analisados. As tabelas 22, 23, 24 e as figuras 84 e 85 sumarizam os resultados obtidos.

Tabela 22 - Média e desvio-padrão da expressão da marcação de tetraciclina em \%, nos 3 campos avaliados, por grupo, em cada período estudado. Os dados foram analisados estatisticamente entre os campos, grupos e entre os períodos, empregando-se os testes de variância ANOVA a três critérios e teste de Tukey

\begin{tabular}{|c|c|c|c|c|c|c|c|c|c|c|c|c|c|c|}
\hline \multirow{2}{*}{$\begin{array}{l}\text { PERIODO } \\
\text { (SEMANAS) }\end{array}$} & & \multicolumn{3}{|c|}{ OSTEOSCAFTM } & \multicolumn{3}{|c|}{ BIO-OSS $®$} & \multicolumn{3}{|c|}{ BONECERAMIC@ } & \multicolumn{3}{|c|}{ AUTOGENO } & \multirow{2}{*}{$\begin{array}{c}\text { DIF. } \\
\text { GRUPOS }\end{array}$} \\
\hline & & C1 & C2 & C3 & C1 & $\mathrm{C} 2$ & $\mathrm{C3}$ & C1 & C2 & $\mathrm{C3}$ & C1 & C2 & $\mathrm{C3}$ & \\
\hline \multirow[t]{2}{*}{2 a } & Média & 19,05 & 17,72 & 19,55 & 37,43 & 41,60 & 41,94 & 18,67 & 12,1 & 7,79 & 25,86 & 27,43 & 33,23 & \multirow{6}{*}{$P=0,080$} \\
\hline & DP & 8,15 & 11,22 & 6,8 & 9,28 & 20,51 & 9,63 & 15,07 & 15,63 & 3,09 & 13,96 & 15,73 & 9,32 & \\
\hline 4 ab & Média & 7,48 & 14,36 & 11,54 a & 18,92 a & 12,91 & 17,34 & 6,59 & 4,56 & $\mathbf{8 , 8 1}$ & 14,39 & 11,89 & 11,96 & \\
\hline \multirow{3}{*}{8 ab } & DP & 7,15 & 9,15 & 5,8 & 8,17 & 11,87 & 3,71 & 1,72 & 2,37 & $\mathbf{9 , 4 7}$ & 4,50 & 11,16 & 0,67 & \\
\hline & Média & 4,84 & 2,15 & 6,56 a & 5,47 a & 3,63 & 3,20 & 11,12 & 11,44 & 10,93 & 7,63 & 4,54 & 6,50 & \\
\hline & DP & 1,15 & 2,17 & 1,21 & 5,05 & 2,54 & 1,62 & 17,44 & 17,91 & 15,75 & 4,80 & 3,20 & 3,56 & \\
\hline $\begin{array}{l}\text { DIF. } \\
\text { PERIODOS } \\
\mathrm{P}<0,001 *\end{array}$ & \multicolumn{14}{|c|}{$\begin{array}{c}\text { DIF. CAMPOS } \\
P=0,59\end{array}$} \\
\hline
\end{tabular}

* $\mathrm{P}<0,05$ = estatisticamente significante. Períodos com o mesmo conjunto de letras minúsculas não possuem diferença entre si. 
Tabela 23 - Resultados da análise de variância (ANOVA) a 3 critérios para a expressão da marcação de tetraciclina

\begin{tabular}{c|c|c|cc|cc|}
\hline & $\begin{array}{c}\text { df } \\
\text { Effect }\end{array}$ & $\begin{array}{c}\text { MS } \\
\text { Effect }\end{array}$ & $\begin{array}{c}\text { df } \\
\text { Error }\end{array}$ & $\begin{array}{c}\text { MS } \\
\text { Error }\end{array}$ & F & p-level \\
\hline $\mathbf{1}$ & 3 & 565,228 & 24 & 223,1474 & 2,53298 & 0,080887 \\
$\mathbf{2}$ & 2 & 3349,943 & 24 & 223,1474 & 15,01224 & $\mathbf{0 , 0 0 0 0 6 *}$ \\
$\mathbf{3}$ & 2 & 16,66956 & 48 & 31,87187 & 0,523018 & 0,596068 \\
$\mathbf{1 2}$ & 6 & 491,3521 & 24 & 223,1474 & 2,201917 & 0,078193 \\
$\mathbf{1 3}$ & 6 & 12,8294 & 48 & 31,87187 & 0,40253 & 0,873706 \\
$\mathbf{2 3}$ & 4 & 1,656705 & 48 & 31,87187 & 0,05198 & 0,994776 \\
$\mathbf{1 2 3}$ & 12 & 34,92561 & 48 & 31,87187 & 1,095813 & 0,385121 \\
\hline
\end{tabular}

1. Grupo; 2. Período; 3. Campo. *significância para p<0,05

Tabela 24 - Resultados da comparação entre períodos. Teste de Tukey para a expressão da marcação de tetraciclina

\begin{tabular}{|cccc|}
\hline Período & $\{1\}$ & $\{2\}$ & $\{3\}$ \\
\hline $2\{1\}$ & & $\mathbf{0 , 0 0 2 3 7 3 0 9 9 *}$ & $\mathbf{0 , 0 0 0 1 7 9 4 1 *}$ \\
$4\{2\}$ & & 0,315821469 \\
$8\{3\}$ & & \\
\hline
\end{tabular}

*significância para $\mathrm{p}<0,05$

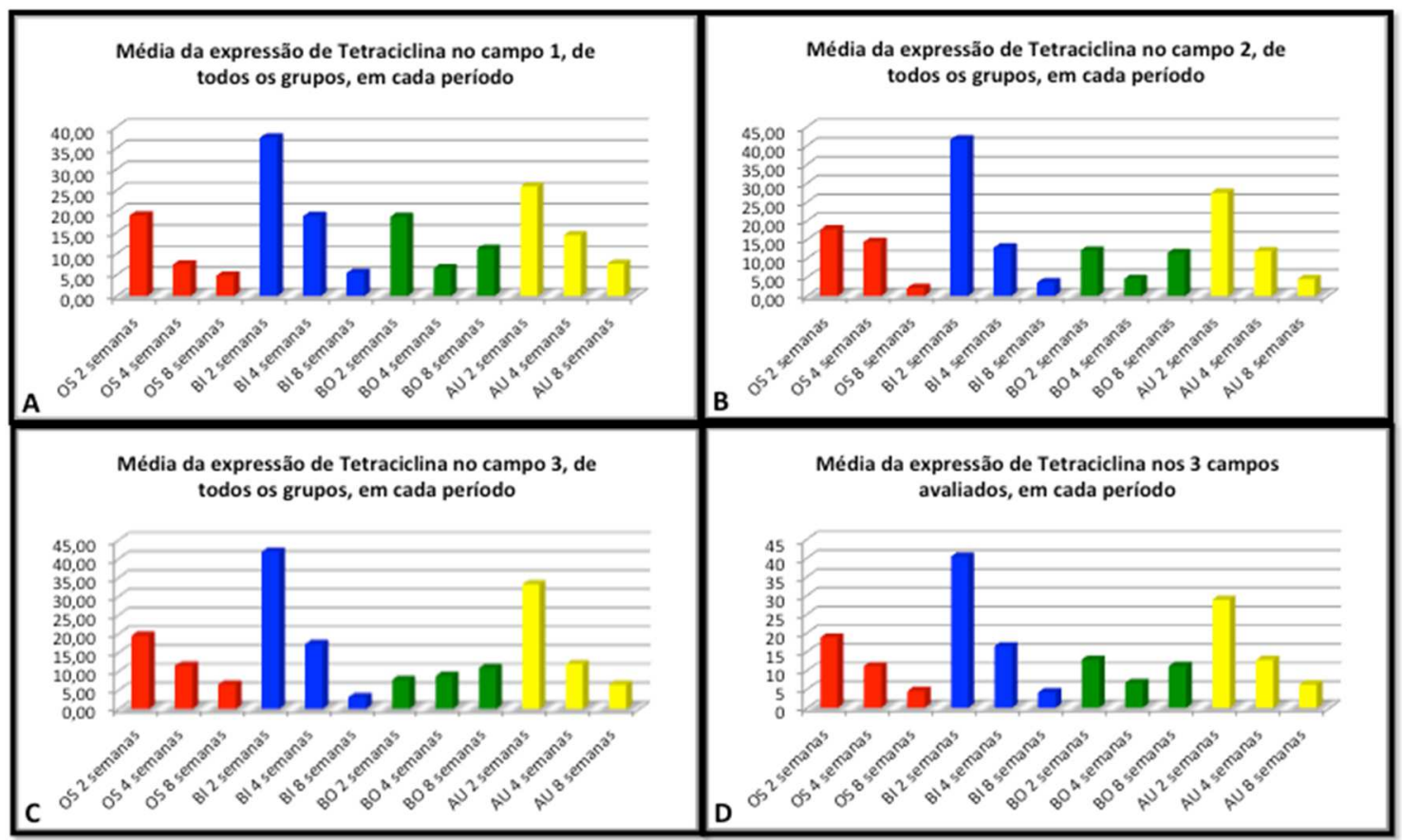

Figura 84 - Gráficos ilustrando a evolução da marcação por tetraciclina nos campos avaliados, por grupo, em cada período. OS: OsteoScaf ${ }^{\mathrm{TM}}$, BI: Bio-Oss ${ }^{\circledR}, \mathrm{BO}$ : BoneCeramic ${ }^{\circledR}$ e AU: osso autógeno 


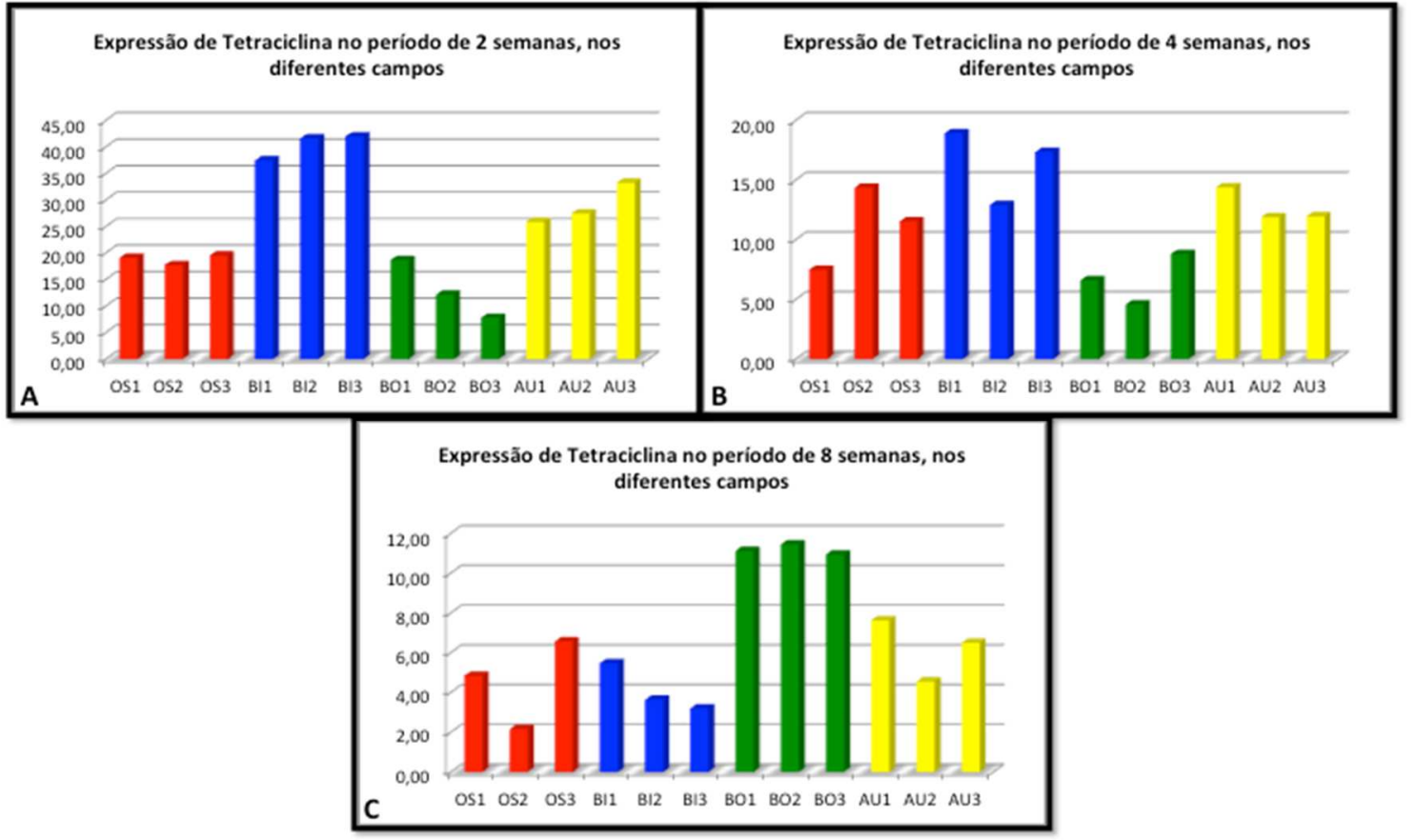

Figura 85 - Gráficos ilustrando a marcação por tetraciclina, nos diferentes campos ou áreas do levantamento de seio maxilar, em cada período. OS: OsteoScaf ${ }^{\mathrm{TM}}$, BI: Bio-Oss ${ }^{\circledR}$, BO: BoneCeramic ${ }^{\circledR}$ e AU: osso autógeno

\subsubsection{Variável alizarina}

O marcador ósseo alizarina foi observado em todos os grupos e nos períodos de 4 e 8 semanas. Não houve diferença entre os grupos e nem entre os períodos, porém houve diferença entre os campos analisados. As tabelas 25, 26, 27 e as figuras 86 e 87 sumarizam os resultados obtidos.

Tabela 25 - Média e desvio-padrão da expressão da marcação por alizarina em \%, nos 3 campos avaliados, por grupo, em cada período estudado. Os dados foram analisados estatisticamente entre os campos, grupos e entre os períodos, empregando-se os testes de variância ANOVA a três critérios e teste de Tukey

\begin{tabular}{|c|c|c|c|c|c|c|c|c|c|c|c|c|c|c|}
\hline \multirow{2}{*}{$\begin{array}{l}\text { PERIODO } \\
\text { (SEMANAS) }\end{array}$} & & \multicolumn{3}{|c|}{ OSTEOSCAF'TM } & \multicolumn{3}{|c|}{ BI0-0SS $(B)$} & \multicolumn{3}{|c|}{ BONECERAMIC@ } & \multicolumn{3}{|c|}{ AUTOGENO } & \multirow{2}{*}{$\begin{array}{c}\text { DIF. } \\
\text { GRUPOS }\end{array}$} \\
\hline & & $\mathrm{C} 1 \mathrm{ab}$ & C2 ab & C3 a & $\mathrm{C1}$ ab & C2 ab & C3 a & C1 ab & C2 ab & C3 a & C1 ab & C2 ab & $\mathrm{C3}$ a & \\
\hline 4 & Média & 1,79 & 1,67 & 2,95 & 0,65 & 0,43 & 2,92 & 0,73 & 0,60 & 3,23 & 2,26 & 1,81 & 4,74 & \\
\hline & DP & 1,32 & 2,03 & 3,77 & 0,68 & 0,32 & 3,41 & 0,54 & 0,53 & 4,03 & 0,28 & 2,45 & 3,78 & $P=0,63$ \\
\hline 8 & Média & 2,90 & 0,77 & 4,07 & 2,64 & 0,97 & 2,34 & 6,14 & 3,33 & 7,17 & 3,83 & 2,45 & 4,69 & \\
\hline & DP & 1,28 & 1,20 & 1,92 & 1,39 & 1,00 & 1,77 & 8,96 & 3,41 & 7,77 & 1,52 & 0,46 & 0,63 & \\
\hline $\begin{array}{l}\text { DIF. } \\
\text { PERIODOS } \\
\mathrm{P}=\mathbf{0 , 2 1}\end{array}$ & \multicolumn{14}{|c|}{ DIF. CAMPOS } \\
\hline
\end{tabular}

* $\mathrm{P}<0,05$ = estatisticamente significante. Campos com o mesmo conjunto de letras minúsculas não possuem diferença entre si 
Tabela 26 - Resultados da análise de variância (ANOVA) a 3 critérios para a expressão da marcação por alizarina

\begin{tabular}{|c|c|c|c|c|c|c|}
\hline & $\begin{array}{c}\text { df } \\
\text { Effect }\end{array}$ & $\begin{array}{c}\text { MS } \\
\text { Effect }\end{array}$ & $\begin{array}{l}\text { df } \\
\text { Error }\end{array}$ & $\begin{array}{l}\text { MS } \\
\text { Error }\end{array}$ & $\mathbf{F}$ & p-level \\
\hline 1 & 3 & 13,48766 & 16 & 22,89692 & 0,58906 & 0,630985 \\
\hline 2 & 1 & 38,3542 & 16 & 22,89692 & 1,675081 & 0,213949 \\
\hline 3 & 2 & 37,94814 & 32 & 3,395576 & 11,17576 & $0,000208 *$ \\
\hline 12 & 3 & 13,19558 & 16 & 22,89692 & 0,576304 & 0,63887 \\
\hline 13 & 6 & 0,510824 & 32 & 3,395576 & 0,150438 & 0,987627 \\
\hline 23 & 2 & 5,23111 & 32 & 3,395576 & 1,540566 & 0,229732 \\
\hline 123 & 6 & 0,992525 & 32 & 3,395576 & 0,292299 & 0,936187 \\
\hline
\end{tabular}

1. Grupo; 2. Período; 3. Campo. *significância para p<0,05

Tabela 27 - Resultados da comparação entre campos. Teste de Tukey para a expressão da marcação por alizarina

\begin{tabular}{|c|c|c|c|}
\hline Campos & $\{1\}$ & $\{2\}$ & $\{3\}$ \\
\hline $1\{1\}$ & & 0,107361436 & $0,034400046 *$ \\
\hline $2\{2\}$ & & & $0,000239611 *$ \\
\hline $3\{3\}$ & & & \\
\hline
\end{tabular}

*significância para $\mathrm{p}<0,05$

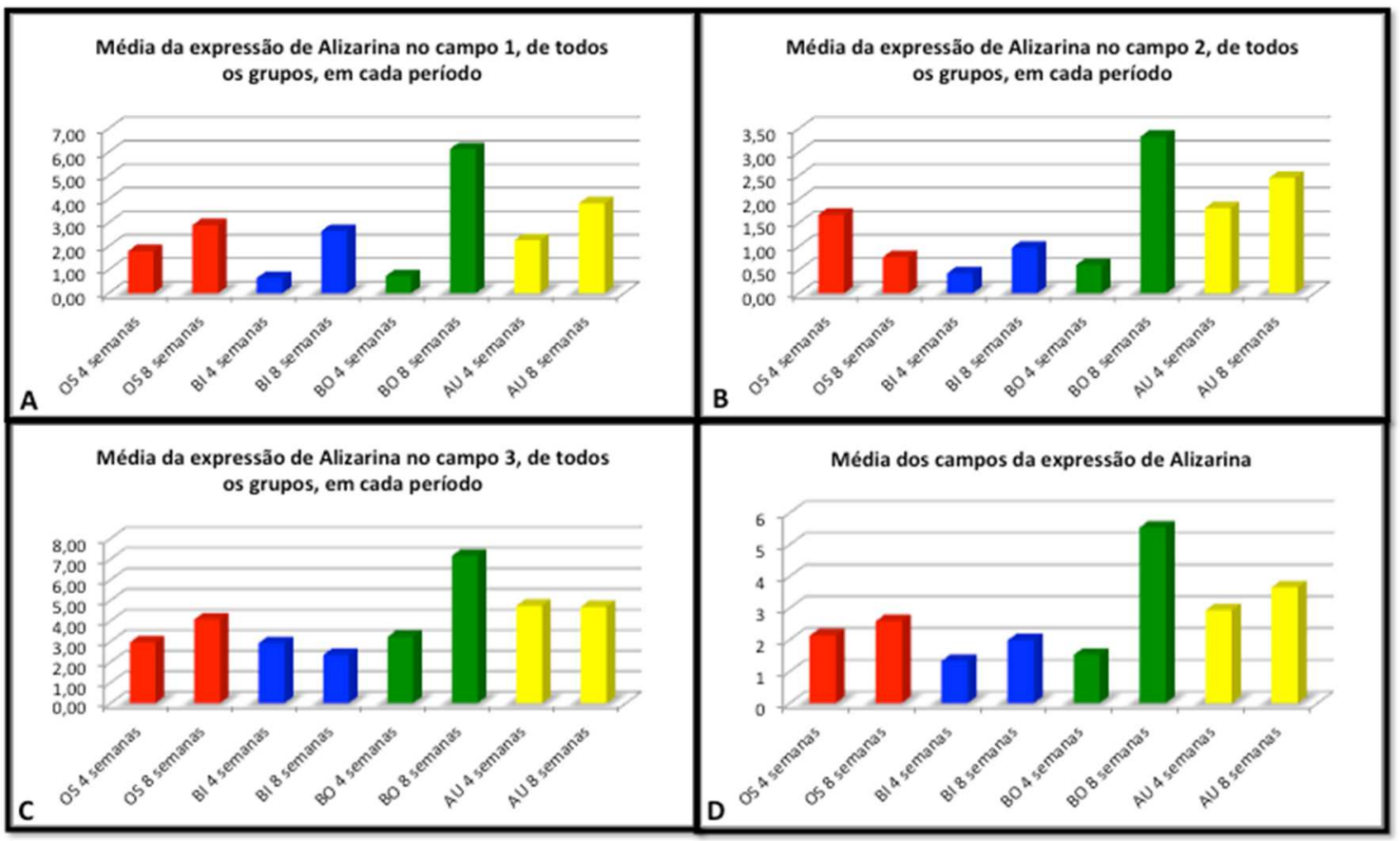

Figura 86 - Gráficos ilustrando a evolução da marcação por alizarina nos campos avaliados, por grupo, em cada período. OS: OsteoScaf ${ }^{\mathrm{TM}}, \mathrm{BI}$ : Bio-Oss ${ }^{\circledR}, \mathrm{BO}$ : BoneCeramic ${ }^{\circledR}$ e AU: osso autógeno 


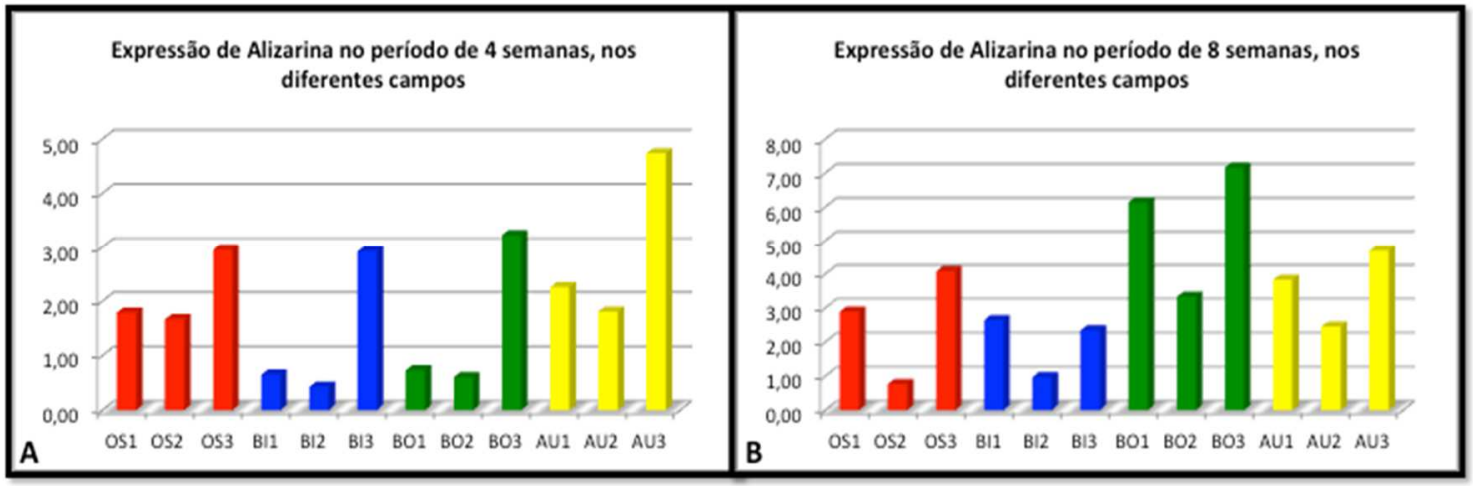

Figura 87 - Gráficos ilustrando a marcação por alizarina nos diferentes campos ou áreas do levantamento de seio maxilar, em cada período. OS: OsteoScaf ${ }^{\mathrm{TM}}$, BI: Bio-Oss ${ }^{\circledR}, \mathrm{BO}$ : BoneCeramic ${ }^{\circledR}$ e AU: osso autógeno

\subsubsection{Variável calceína}

O marcador ósseo calceína foi observado em todos os grupos e nos períodos de 8 semanas. Não houve diferença entre os grupos, porém houve diferença entre os campos analisados. As tabelas 28, 29, 30 e a figura 88 sumarizam os resultados obtidos.

Tabela 28 - Média e desvio-padrão da expressão da marcação por calceína nos 3 campos avaliados, por grupo, no período de 8 semanas. Os dados foram analisados estatisticamente entre os campos, grupos e entre os períodos, empregando-se os testes de variância ANOVA a três critérios e teste de Tukey

\begin{tabular}{|c|c|c|c|c|c|c|c|c|c|c|c|c|c|c|}
\hline \multirow{2}{*}{\multicolumn{2}{|c|}{$\begin{array}{l}\text { PERIODO } \\
\text { (SEMANAS) }\end{array}$}} & \multicolumn{3}{|c|}{ OSTEOSCAFTM } & \multicolumn{3}{|c|}{ BIO-OSS $\odot$} & \multicolumn{3}{|c|}{ BONECERAMIC@ } & \multicolumn{3}{|c|}{ AUTOGENO } & \multirow{2}{*}{$\begin{array}{c}\text { DIF. } \\
\text { GRUPOS }\end{array}$} \\
\hline & & C1 a & $\mathrm{C} 2 \mathrm{ab}$ & $\mathrm{C3} \mathrm{ab}$ & C1 a & $\mathrm{C2}$ al & $\mathrm{C3} \mathrm{ab}$ & C1 a & C2 ab & C3 ab & C1 a & $\mathrm{C} 2 \mathrm{ab}$ & $\mathrm{C} 3 \mathrm{ab}$ & \\
\hline 8 & Média & 3,76 & 0,76 & 3,96 & 3,34 & 1,20 & 2,78 & 4,65 & 3,18 & 7,08 & 2,04 & 3,04 & 5,53 & $P=0,5650$ \\
\hline & DP & 0,05 & 1,20 & 1,37 & 1,02 & 1,48 & 2,01 & 4,68 & 1,60 & 5,45 & 2,59 & $\mathbf{0 , 3 3}$ & 2,43 & \\
\hline & \multicolumn{14}{|c|}{$\begin{array}{c}\text { DIF. CAMPOS } \\
P=0,0014 *\end{array}$} \\
\hline
\end{tabular}

* $\mathrm{P}<0,05$ = estatisticamente significante. Campos com o mesmo conjunto de letras minúsculas possuem diferença entre si

Tabela 29 - Resultados da análise de variância (ANOVA) a 2 critérios para a expressão da marcação por calceína

\begin{tabular}{ccccccc}
\hline & $\begin{array}{c}\text { df } \\
\text { Effect }\end{array}$ & $\begin{array}{c}\text { MS } \\
\text { Effect }\end{array}$ & $\begin{array}{c}\text { df } \\
\text { Error }\end{array}$ & $\begin{array}{c}\text { MS } \\
\text { Error }\end{array}$ & F & p-level \\
\hline $\mathbf{1}$ & 3 & 11,19128 & 8 & 15,43994 & 0,724827 & 0,565076 \\
2 & 2 & 23,40836 & 16 & 2,331532 & 10,0399 & $\mathbf{0 , 0 0 1 4 9 6 *}$ \\
12 & 6 & 3,756773 & 16 & 2,331532 & 1,61129 & 0,207907 \\
\hline
\end{tabular}

1. Grupo; 2. Campo. *significância para $p<0,05$ 
Tabela 30 - Resultados da comparação entre campos para a expressão da marcação por calceína

\begin{tabular}{cccc}
\hline Campo & $\{1\}$ & $\{2\}$ & $\{3\}$ \\
\hline $1\{1\}$ & & 0,092519462 & 0,09663856 \\
$2\{2\}$ & & $\mathbf{0 , 0 0 1 1 5 7 5 8 2 *}$ \\
\hline $3\{3\}$ & & & \\
\hline
\end{tabular}

*significância para $\mathrm{p}<0,05$

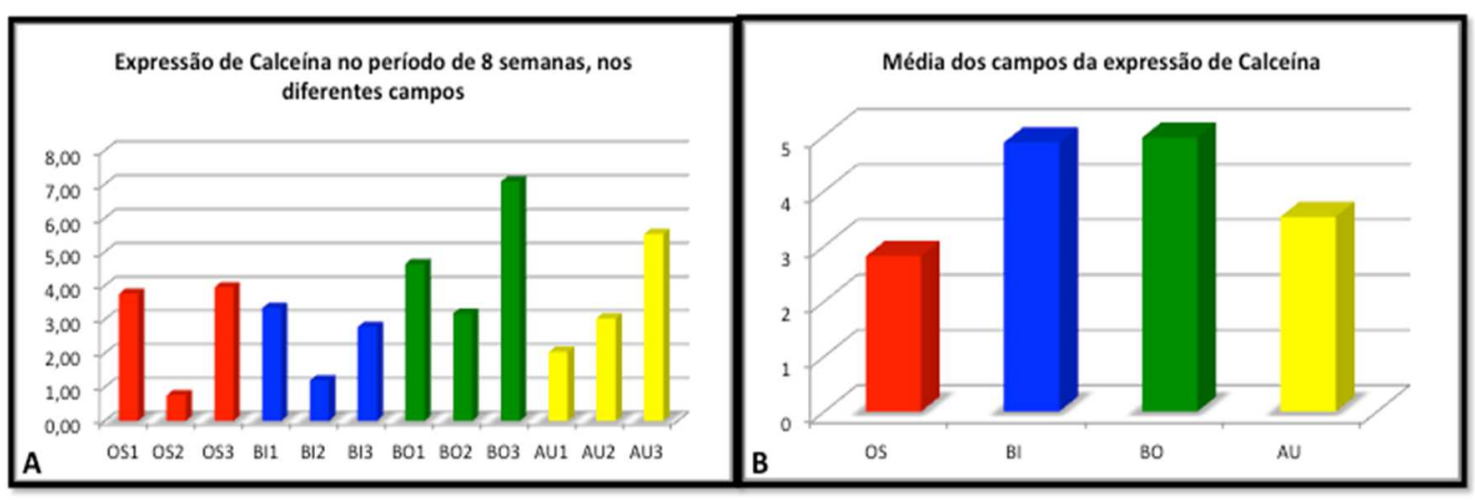

Figura 88 - A. Gráfico ilustrando a marcação por calceína nos diferentes campos ou áreas do levantamento de seio maxilar, no período de 8 semanas. B. Média dos campos da marcação por calceína. OS: OsteoScaf ${ }^{\mathrm{TM}}$, BI: Bio-Oss $\AA$, BO: BoneCeramic $®$ e AU: osso autógeno

\subsection{Análise molecular}

Os resultados foram analisados com base no valor de $\mathrm{Ct}$ (cicle threshold - ou ciclo limiar), sendo este o ponto correspondente ao número de ciclos em que a amplificação das amostras atinge um limiar (determinado entre o nível de fluorescência dos controles negativos e a fase de amplificação exponencial das amostras) que permite a análise quantitativa da expressão do fator avaliado. Todas as amostras também foram submetidas a reações para a detecção de RNA mensageiro (mRNA) para a beta-actina, um gene de expressão constitutiva, utilizado como controle positivo da reação de amplificação, assim como os níveis de expressão de beta-actina foram utilizados para a normalização dos níveis de expressão do gene alvo. Uma amostra negativa (água) foi submetida à reação com cada par das sequências dos primers utilizados. Os resultados apresentados representam os valores da intensidade de expressão de de RNA mensageiro (mRNA) para o gene alvo, normalizado pela expressão da beta-actina, obtidos de cada animal de cada grupo. 
Diante da variação da quantidade de amostras, em alguns grupos e períodos, não foi possível realizar análise estatística; portanto o resultado de cada amostra e, quando possível, da média de cada grupo, foram descritos nas tabelas 31-44.

\subsubsection{Variável colágeno tipo 1 alfa 1 (COL1A1)}

Tabela 31 - Variável COL1A1. Resultados dos valores da expressão de mRNA para o gene alvo, obtidos de cada animal por grupo, em cada período

\begin{tabular}{|c|c|c|c|c|}
\hline Período & OsteoScaf & Bio-Oss ® & BoneCeramic® & Autógeno \\
\hline \multirow[t]{4}{*}{2} & 6,21 & 5,85 & 4,69 & 6,58 \\
\hline & 5,93 & 5,54 & 5,05 & - \\
\hline & 6,79 & - & - & - \\
\hline & Média: 6,31 & Média: 5,69 & Média: 4,82 & Média: 6,58 \\
\hline \multirow[t]{3}{*}{4} & 11,51 & 11,51 & 8,64 & 12,54 \\
\hline & 14,57 & 13,96 & - & - \\
\hline & Média: 13,04 & Média: 12,73 & Média: 8,64 & Média: 12,54 \\
\hline \multirow[t]{4}{*}{8} & 10,96 & 12,65 & 8,95 & 10,95 \\
\hline & 11,62 & 14,69 & 7,62 & - \\
\hline & 13,12 & - & - & - \\
\hline & Média: 11,9 & Média: 13,67 & Média: 8,28 & Média: 10,95 \\
\hline
\end{tabular}

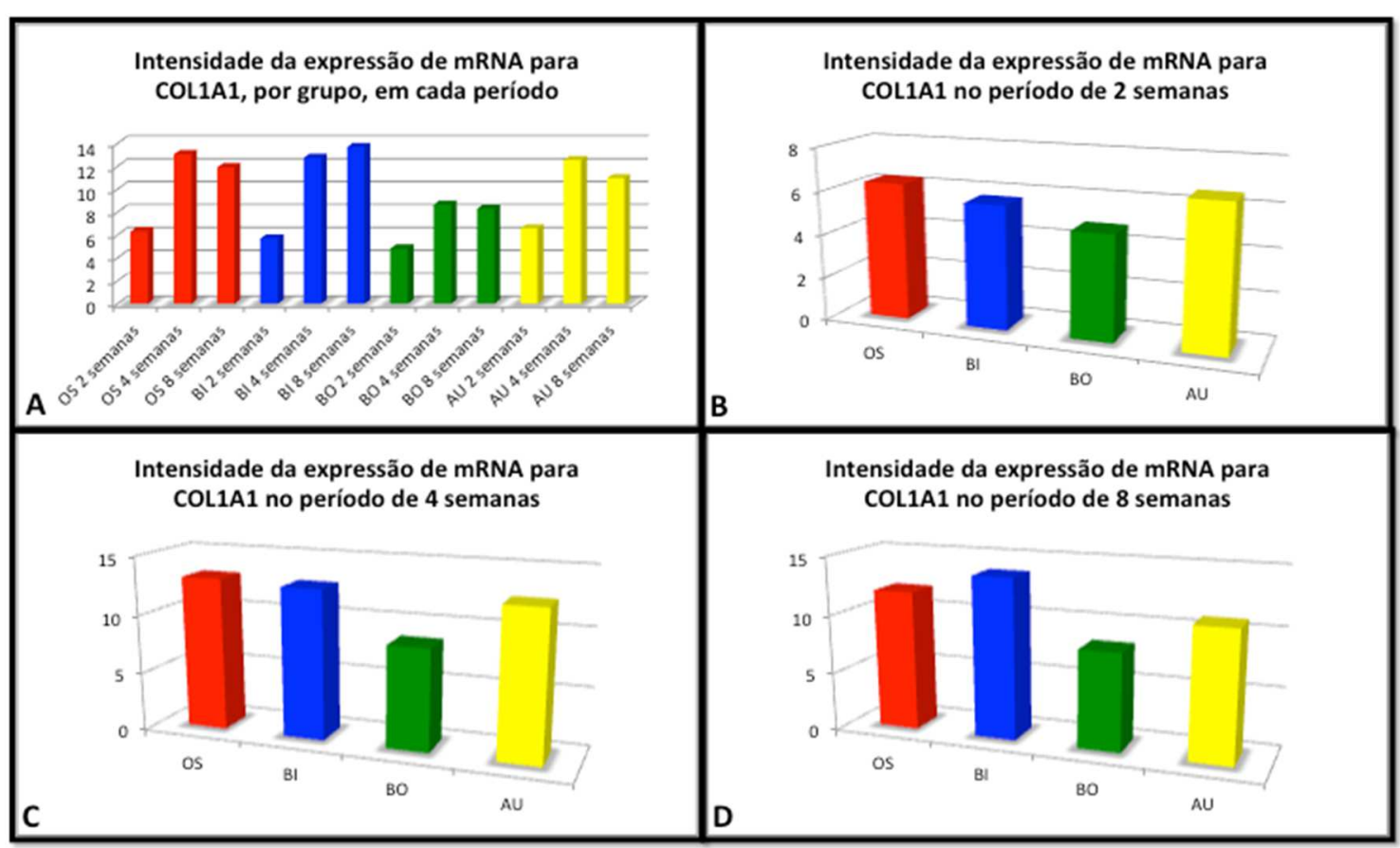

Figura 89 - Gráficos ilustrativos da expressão de mRNA para COL1A1. A. Evolução da expressão de mRNA para COL1A1, por grupo, ao longo do tempo. B. Expressão de mRNA para COL1A1, por grupo, no período de 2 semanas. C. Expressão de mRNA para COL1A1, por grupo, no período de 4 semanas. D. Expressão de mRNA para COL1A1, por grupo, no período de 8 semanas. OS: OsteoScaf ${ }^{\mathrm{TM}}$, BI: Bio-Oss ${ }^{\circledR}, \mathrm{BO}$ : BoneCeramic ${ }^{\circledR}$ e AU: osso autógeno 


\subsubsection{Variável fator de crescimento vascular endotelial (VEGF)}

Tabela 32 - Variável VEGF. Resultados dos valores da expressão de mRNA para o gene alvo, obtidos de cada animal por grupo, em cada período

\begin{tabular}{|c|c|c|c|c|}
\hline Período & OsteoScaf ${ }^{\mathrm{TM}}$ & Bio-Oss@ & BoneCeramic ${ }^{\circledR}$ & Autógeno \\
\hline \multirow[t]{4}{*}{2} & 5,12 & 4,15 & 3,66 & 6,96 \\
\hline & 3,96 & 5,62 & 3,12 & - \\
\hline & 4,18 & - & - & - \\
\hline & Média: $\mathbf{4 , 4 2}$ & Média: 4,88 & Média: 3,39 & Média: 6,96 \\
\hline \multirow[t]{3}{*}{4} & 6,21 & 5,95 & 3,74 & 4,54 \\
\hline & 4,15 & 6,91 & - & - \\
\hline & Média: 5,18 & Média: 6,43 & Média: 3,74 & Média: 4,54 \\
\hline \multirow[t]{4}{*}{8} & 3,33 & 3,51 & 4,15 & 3,96 \\
\hline & 4,15 & 2,68 & 4,32 & - \\
\hline & 3,26 & - & - & - \\
\hline & Média: 3,58 & Média: 3,09 & Média: 4,23 & Média: 3,96 \\
\hline
\end{tabular}

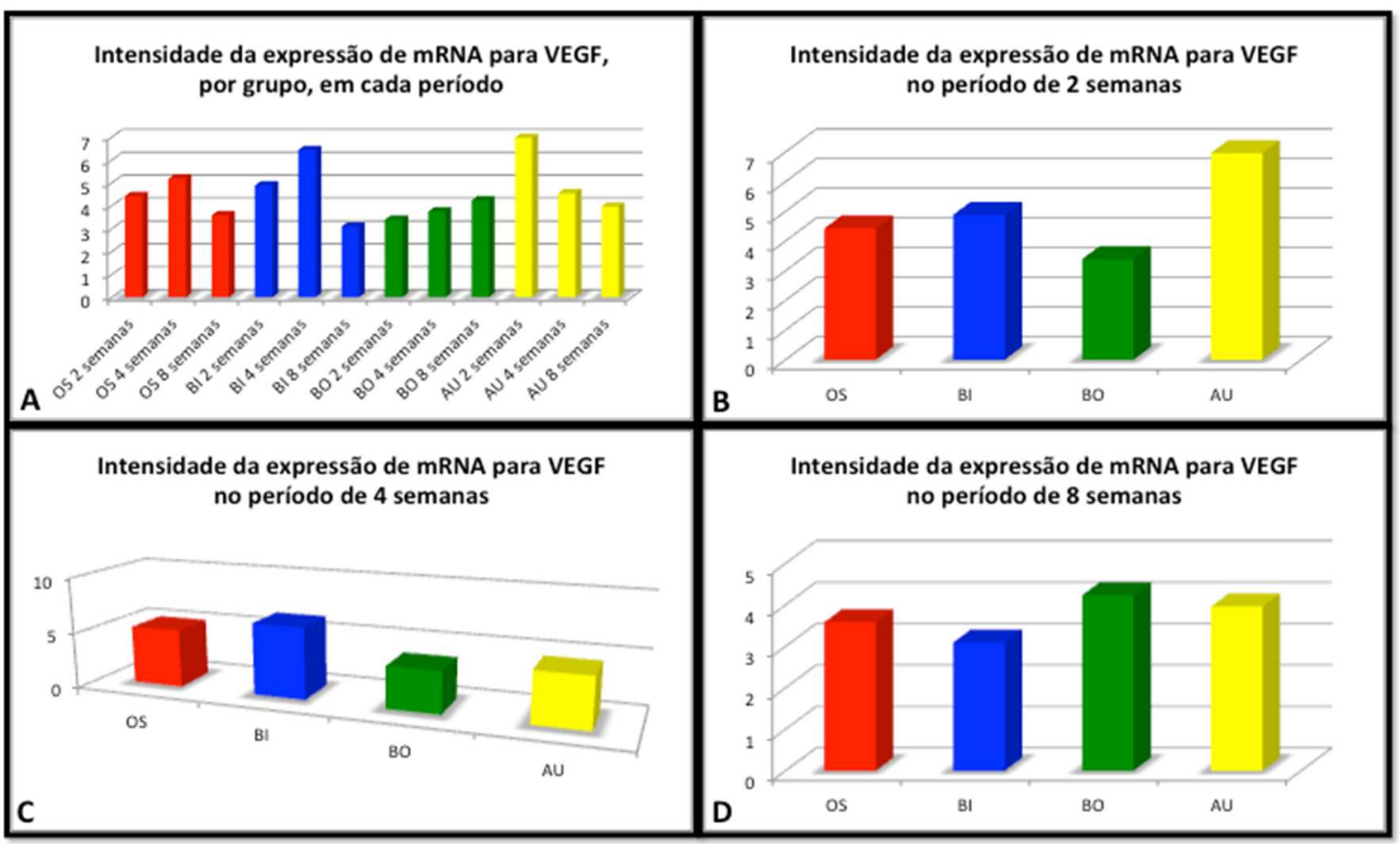

Figura 90 - Gráficos ilustrativos da expressão de mRNA para VEGF. A. Evolução da expressão de mRNA para VEGF, por grupo, ao longo do tempo. B. Expressão de mRNA para VEGF, por grupo, no período de 2 semanas. C. Expressão de mRNA para VEGF, por grupo, no período de 4 semanas. D. Expressão de mRNA para VEGF, por grupo, no período de 8 semanas. OS: OsteoScaf ${ }^{\mathrm{TM}}$, BI: Bio-Oss ${ }^{\circledR}, \mathrm{BO}$ : BoneCeramic ${ }^{\circledR}$ e AU: osso autógeno 


\subsubsection{Variável runt-related transcription factor 2 (RUNX2)}

Tabela 33 - Variável RUNX2. Resultados dos valores da expressão de mRNA para o gene alvo, obtidos de cada animal por grupo, em cada período

\begin{tabular}{|c|c|c|c|c|}
\hline Período & OsteoScaf ${ }^{\mathrm{TM}}$ & Bio-Oss@ & BoneCeramic $₫$ & Autógeno \\
\hline \multirow[t]{4}{*}{2} & 5,92 & 6,95 & 3,69 & 9,21 \\
\hline & 6,51 & 7,81 & 4,51 & - \\
\hline & 6,12 & - & - & - \\
\hline & Média: 6,18 & Média: 7,38 & Média: 4,1 & Média: 9,21 \\
\hline \multirow[t]{3}{*}{4} & 10,35 & 12,68 & 14,52 & 14,21 \\
\hline & 11,31 & 11,41 & - & - \\
\hline & Média: $\mathbf{1 0 , 8 3}$ & Média: 12,04 & Média: 14,52 & Média: 14,21 \\
\hline \multirow[t]{4}{*}{8} & 10,24 & 13,58 & 10,51 & 10,51 \\
\hline & 9,68 & 12,62 & 7,53 & - \\
\hline & 9,35 & - & - & - \\
\hline & Média: 9,75 & Média: 13,1 & Média: 9,02 & Média: 10,51 \\
\hline
\end{tabular}

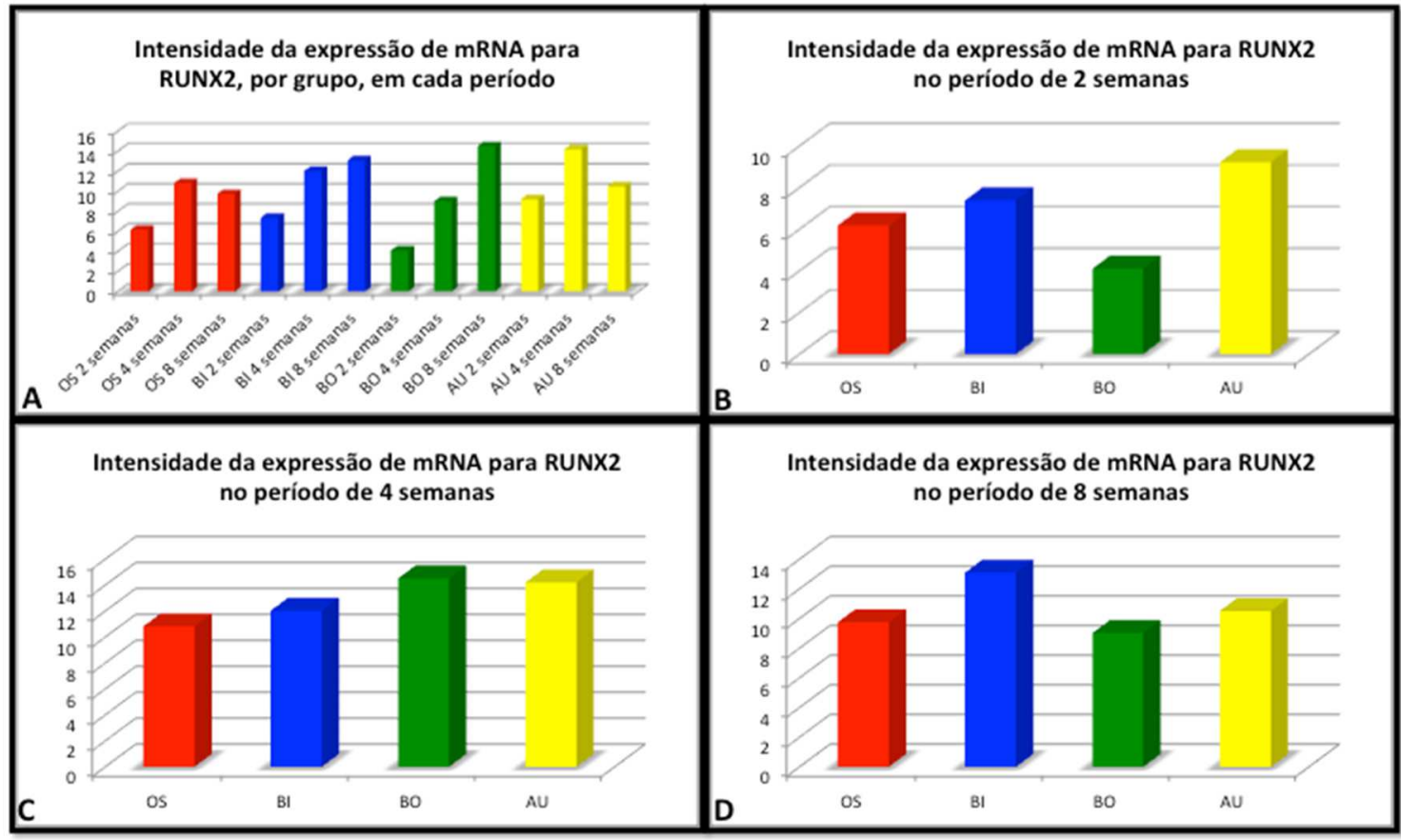

Figura 91 - Gráficos ilustrativos da expressão de mRNA para RUNX2. A. Evolução da expressão de mRNA para RUNX2, por grupo, ao longo do tempo. B. Expressão de mRNA para RUNX2, por grupo, no período de 2 semanas. C. Expressão de mRNA para RUNX2, por grupo, no período de 4 semanas. D. Expressão de mRNA para RUNX2, por grupo, no período de 8 semanas. OS: OsteoScaf ${ }^{\mathrm{TM}}$, BI: Bio-Oss ${ }^{\circledR}, \mathrm{BO}$ : BoneCeramic ${ }^{\circledR}$ e AU: osso autógeno 


\subsubsection{Variável proteína óssea morfogenética 2 (BMP-2)}

Tabela 34 - Variável BMP-2. Resultados dos valores da expressão de mRNA para o gene alvo, obtidos de cada animal por grupo, em cada período

\begin{tabular}{|c|c|c|c|c|}
\hline Período & OsteoScaf' & Bio-Oss ${ }^{\circledR}$ & BoneCeramic ${ }^{\circledR}$ & Autógeno \\
\hline \multirow[t]{4}{*}{2} & 3,68 & 4,51 & 2,85 & 6,58 \\
\hline & 3,81 & 3,69 & 2,16 & - \\
\hline & 4,41 & & - & - \\
\hline & Média: 3,96 & Média: 4,1 & Média: 2,50 & Média: 6,58 \\
\hline \multirow[t]{3}{*}{4} & 5,86 & 6,95 & 5,74 & 7,54 \\
\hline & 6,34 & 7,13 & - & - \\
\hline & Média: 6,1 & Média: 7,04 & Média: 5,74 & Média: 7,54 \\
\hline \multirow[t]{4}{*}{8} & 3,71 & 2,69 & 4,51 & 3,62 \\
\hline & 2,96 & 4,51 & 3,85 & - \\
\hline & 3,13 & - & - & - \\
\hline & Média: 3,26 & Média: 3,6 & Média: 4,18 & Média: 3,62 \\
\hline
\end{tabular}

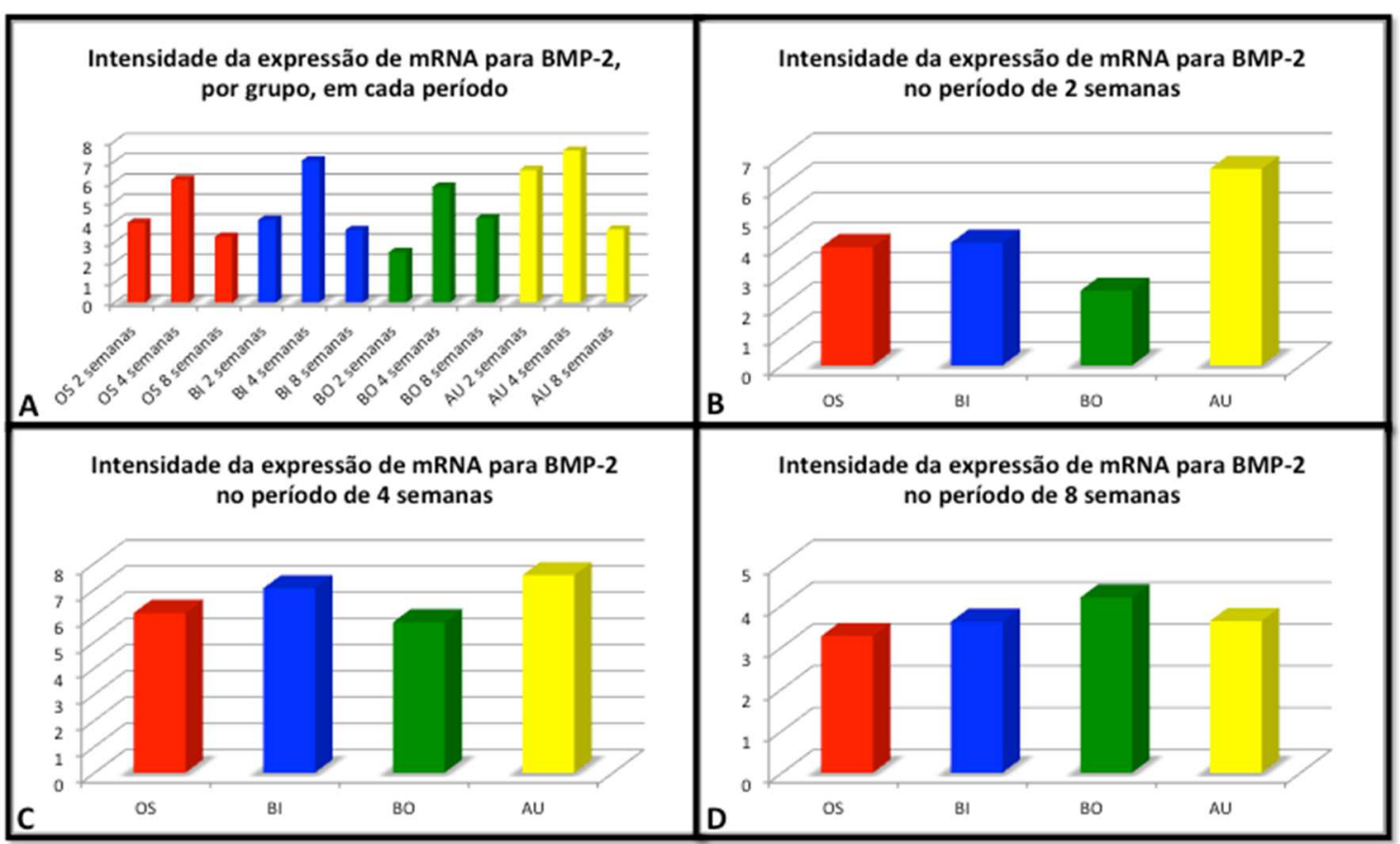

Figura 92 - Gráficos ilustrativos da expressão de mRNA para BMP-2. A. Evolução da expressão de mRNA para BMP2, por grupo, ao longo do tempo. B. Expressão de mRNA para BMP-2, por grupo, no período de 2 semanas. C. Expressão de mRNA para BMP-2, por grupo, no período de 4 semanas. D. Expressão de mRNA para BMP-2, por grupo, no período de 8 semanas. OS: OsteoScaf ${ }^{\mathrm{TM}}$, BI: Bio-Oss ${ }^{\circledR}$, BO: BoneCeramic ${ }^{\circledR}$ e AU: osso autógeno 


\subsubsection{Variável osteonectina (SPARC)}

Tabela 35 - Variável SPARC. Resultados dos valores da expressão de mRNA para o gene alvo, obtidos de cada animal por grupo, em cada período

\begin{tabular}{|c|c|c|c|c|}
\hline Período & OsteoScaf'TM & Bio-Oss® & BoneCeramic $(8)$ & Autógeno \\
\hline \multirow{4}{*}{2} & 6,95 & 5,62 & 5,13 & 7,41 \\
\hline & 7,84 & 4,93 & 4,88 & - \\
\hline & 5,92 & - & - & - \\
\hline & Média: 6,90 & Média: 5,27 & Média: 5,0 & Média: 7,41 \\
\hline \multirow[t]{3}{*}{4} & 4,73 & 4,63 & 5,18 & 5,85 \\
\hline & 5,20 & 3,66 & - & - \\
\hline & Média: 4,96 & Média: 4,14 & Média: 5,18 & Média: 5,85 \\
\hline \multirow[t]{4}{*}{8} & 3,62 & 4,51 & 6,08 & 4,96 \\
\hline & 4,91 & 3,69 & 5,15 & - \\
\hline & 3,35 & - & - & - \\
\hline & Média: 3,96 & Média: 4,1 & Média: 5,61 & Média: 4,96 \\
\hline
\end{tabular}

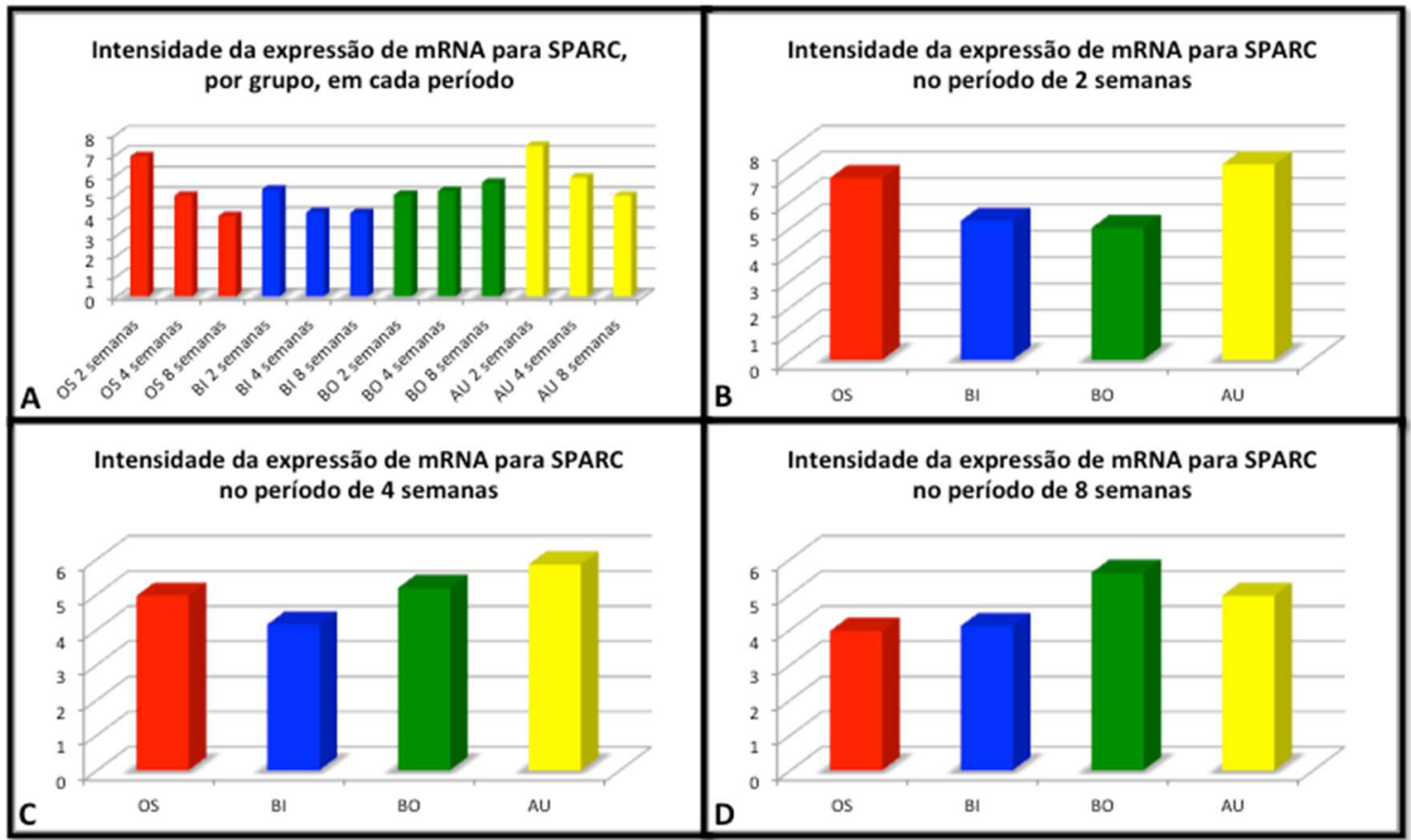

Figura 93 - Gráficos ilustrativos da expressão de mRNA para SPARC. A. Evolução da expressão de mRNA para SPARC, por grupo, ao longo do tempo. B. Expressão de mRNA para SPARC, por grupo, no período de 2 semanas. C. Expressão de mRNA para SPARC, por grupo, no período de 4 semanas. D. Expressão de mRNA para SPARC, por grupo, no período de 8 semanas. OS: OsteoScaf ${ }^{\mathrm{TM}}$, BI: Bio-Oss ${ }^{\circledR}, \mathrm{BO}$ : BoneCeramic ${ }^{\circledR}$ e AU: osso autógeno 


\subsubsection{Variável fosfatase alcalina (ALPL)}

Tabela 36 - Variável ALPL. Resultados dos valores da intensidade de expressão de mRNA para o gene alvo, obtidos de cada animal por grupo em cada período

\begin{tabular}{|c|c|c|c|c|}
\hline Período & OsteoScaf TM & Bio-Oss® & BoneCeramic $₫$ & Autógeno \\
\hline \multirow[t]{4}{*}{2} & 7,13 & 9,32 & 6,95 & 10,32 \\
\hline & 9,62 & 8,25 & 7,03 & - \\
\hline & 11,51 & - & - & - \\
\hline & Média: 9,42 & Média: 8,78 & Média: 6,99 & Média: 10,32 \\
\hline \multirow[t]{3}{*}{4} & 17,51 & 18,95 & 19,03 & 16,69 \\
\hline & 16,95 & 20,51 & - & - \\
\hline & Média: 17,23 & Média: 19,73 & Média: 19,03 & Média: 16,69 \\
\hline \multirow[t]{4}{*}{8} & 11,51 & 10,51 & 8,62 & 8,95 \\
\hline & 8,95 & 9,65 & $\mathbf{9 , 0 7}$ & - \\
\hline & 9,06 & - & - & - \\
\hline & Média: 9,84 & Média: 10,08 & Média: 8,84 & Média: 8,95 \\
\hline
\end{tabular}

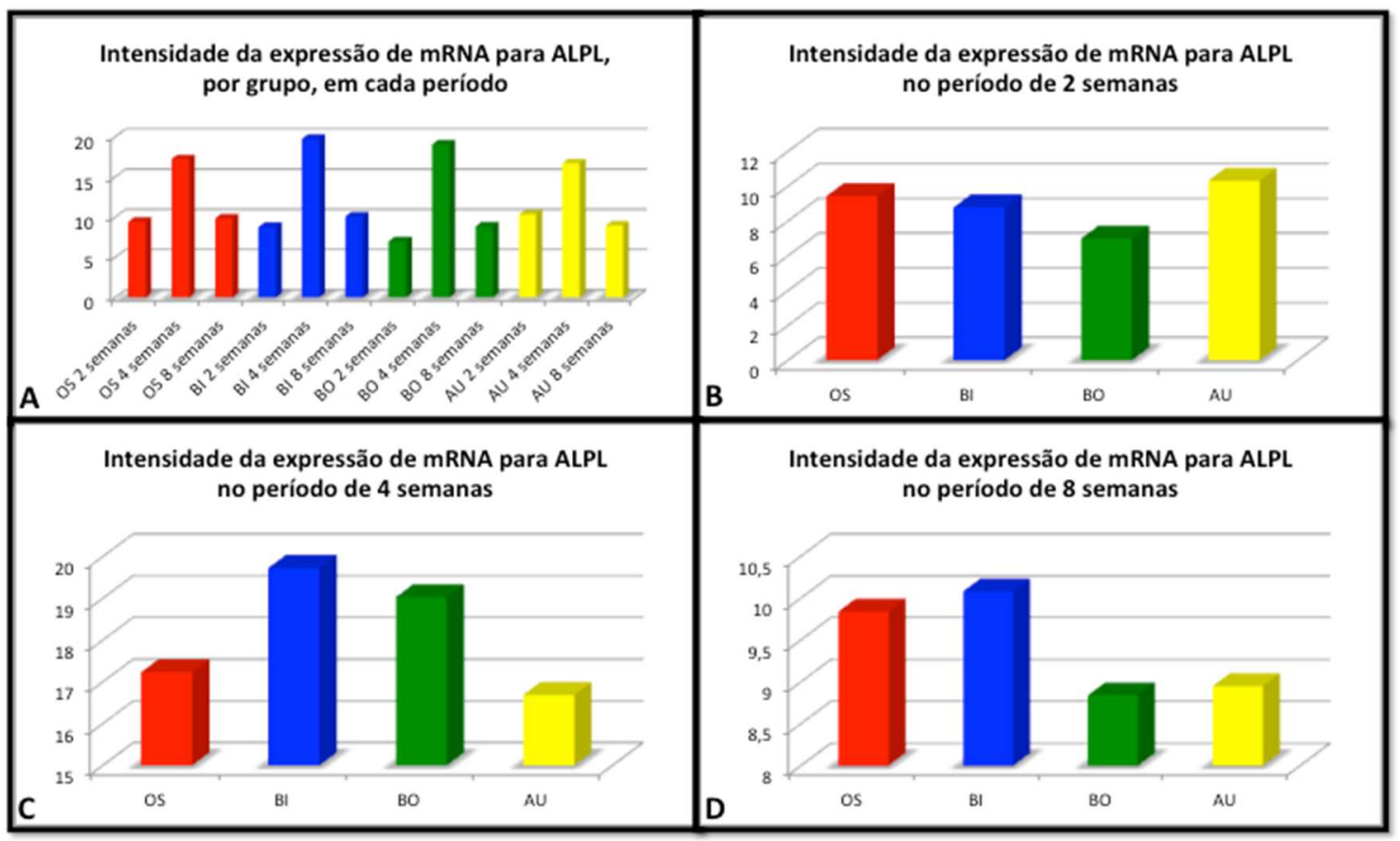

Figura 94 - Gráficos ilustrativos da expressão de mRNA para ALPL. A. Evolução da expressão de mRNA para ALPL, por grupo, ao longo do tempo. B. Expressão de mRNA para ALPL, por grupo, no período de 2 semanas. C. Expressão de mRNA para ALPL, por grupo, no período de 4 semanas. D. Expressão de mRNA para ALPL, por grupo, no período de 8 semanas. OS: OsteoScaf ${ }^{\mathrm{TM}}$, BI: Bio-Oss ${ }^{\circledR}, \mathrm{BO}$ : BoneCeramic ${ }^{\circledR}$ e AU: osso autógeno 
6 Discussão 



\section{DISCUSSAO}

Neste capítulo, foram discutidos aspectos relacionados à metodologia aplicada ao experimento e os resultados encontrados nas diferentes análises, os quais foram criteriosamente analisados após considerar algumas limitações que pudessem dificultar a conclusão deste trabalho.

\subsection{Da Metodologia}

Atualmente, o procedimento de levantamento de seio maxilar é bastante aplicado quando o volume ósseo, necessário para instalação de implantes, é limitado pela presença do seio maxilar associada à severa perda da altura óssea. Desde o primeiro relato por Boyne e James (1980), o volume ósseo do rebordo alveolar pode ser aumentado utilizando um enxerto de osso autógeno, substitutos ósseos ou biomateriais e até mesmo a associação destes. Apesar do osso autógeno ser considerado o padrão-ouro, estudos têm demonstrado perda de volume ósseo ao longo do tempo, especificamente da crista ilíaca (TATUM, 1986; THORWARTH et al., 2005; WATANABE; NIIMI; UEDA, 1999). Em razão disso e de suas limitações associadas com a morbidade cirúrgica, os substitutos ósseos têm sido estudados e aplicados cada vez mais com a mesma finalidade, demonstrando resultados clínicos satisfatórios (MOORE; GRAVES; BAIN, 2001; LAURENCIN; KHAN; EL-AMIN, 2006; WHEELER, 1997).

Muitos estudos clínicos em humanos foram descritos avaliando resultados de levantamento de seio maxilar, porém eles falham na descrição das alterações microscópicas, pois é impossível avaliar a área total de reparo de enxertos em seios maxilares de humanos através da microscopia. Isso justifica os estudos através de modelos experimentais em animais, os quais esclarecem biologicamente a resposta de cada biomaterial ou enxerto ósseo com maior detalhe. Além disso, modelos animais são necessários para aprimorar as técnicas cirúrgicas. Diante das limitações dos estudos em seres humanos, um dos modelos animais mais bem documentados para avaliar o comportamento de biomateriais em levantamento de seio maxilar é realizado em coelhos. Isso porque os coelhos apresentam o mesmo sistema de ventilação aérea que os seres humanos, através da cavidade nasal, com um óstio bem definido 
comunicando às suas cavidades nasais (KUMLIEN; SCHIRATZKI, 1985; SCHARF et al., 1995; WHEELER, 1997).

O primeiro estudo que avaliou o reparo do osso autógeno no interior do seio maxilar e o comportamento da membrana sinusal foi o de Watanabe (1999) (WATANABE; NIIMI; UEDA, 1999). Quando os modelos experimentais animais são aplicados, é importante ter o conhecimento das espécies utilizadas. Coelhos da espécie Oryctolagus cuniculus são animais fáceis de serem reproduzidos com a finalidade científica e a sua manutenção é financeiramente mais viável quando comparados aos animais de porte maiores como macacos, porcos e cabras. A raça utilizada nos trabalhos experimentais de levantamento de seio maxilar é a New Zealand White (BREWER, 2006). Além disso, particularmente, durante as intervenções nos seios maxilares, esses coelhos apresentam anestesia fácil de ser conduzida e ótima recuperação pós-operatória (WATANABE; NIIMI; UEDA, 1999).

Os autores, em 1999, relataram pela primeira vez o comportamento do osso autógeno no seio maxilar de coelhos, diante da ausência de estudos em humanos que viabilizassem uma análise mais completa no interior da cavidade sinusal e as mudanças da membrana sinusal após o enxerto (WATANABE; NIIMI; UEDA, 1999). O experimento foi realizado em coelhos do gênero feminino, pesando 3,1 a $3,4 \mathrm{~kg}$, e a área receptora foi a cavidade sinusal mais inferior, utilizando um acesso extraoral lateral com referência de poucos milímetros acima do osso incisivo e da maxila. O osso autógeno enxertado foi uma porção córticomedular removida da crista ilíaca. Para o acesso da cavidade sinusal, foi utilizada uma broca diamantada e cuidados foram tomados para evitar perfuração. A análise histomorfométrica dos espécimes foi feita e após 2 semanas, quando se constatou a presença de neoformação óssea em continuidade com o assoalho do seio maxilar. Após 4 e 8 semanas, houve um aumento da neoformação óssea com diminuição do osso medular, reabsorção do osso neoformado e o enxertado nas áreas centrais (WATANABE; NIIMI; UEDA, 1999). A partir desse estudo, foi estabelecido de forma bem documentada, um modelo experimental passível de avaliação dos substitutos ósseos no seio maxilar (WATANABE; NIIMI; UEDA, 1999). Outros trabalhos da literatura foram encontrados utilizando essa mesma técnica de acesso (WADA et al., 2001; OHYA et al., 2005; HU et al., 2010).

Em 2002, autores utilizaram um modelo diferente de acesso ao seio maxilar, em coelhos, quando estudaram a influência da pressão aérea e do óstio após o procedimento de levantamento de seio maxilar (ASAI; SHIMIZU; OOYA, 2002). O acesso foi descrito através do osso nasal, atingindo a cavidade sinusal mais superior. A janela óssea foi realizada com $5 \mathrm{~mm}$ de diâmetro e os pontos de referência utilizados foram: $20 \mathrm{~mm}$ anterior à sutura 
nasofrontal e 10mm lateral à linha média. Este modelo permitiu um acesso mais fácil para o estudo de implantes no interior do seio maxilar de coelhos, além de tornar o procedimento cirúrgico mais rápido, diminuindo a morbidade do animal (ASAI; SHIMIZU; OOYA, 2002). A partir desse estudo, outros autores utilizaram o mesmo acesso para avaliar diferentes implantes (HU et al., 2010; XU et al., 2003; XU et al., 2004; SICCA et al., 2008; SUN et al., 2008; SOHN et al., 2010; LAMBERT et al., 2011; MARUKAWA et al., 2011).

No presente trabalho, foi feito um estudo piloto, previamente ao estudo definitivo, na tentativa de definir a melhor forma de acesso cirúrgico e optou-se pela técnica modificada, descrita por Asai (2002), diante da facilidade e rapidez de criação do acesso, o qual contribuiu para melhor recuperação e menor morbidade dos animais deste experimento (ASAI; SHIMIZU; OOYA, 2002). Inicialmente, foi difícil definir o local exato da incisão de acesso ao osso nasal e, após um estudo-piloto, em um animal, foram feitas tentativas cirúrgicas exploratórias e criadas algumas medidas de referência com o auxílio de uma tomografia computadorizada por feixe cônico (TCFC), realizada no crânio do animal. As medidas de referência para se realizar a técnica cirúrgica foram: local de perfuração $2,5 \mathrm{~cm}$ distante da região mais anterior do osso nasal (ápice nasal) e $0,5 \mathrm{~cm}$ distante sagitalmente da sutura nasal. As medidas foram criadas através da TCFC, quando se percebeu uma falha no preenchimento sinusal, durante o estudo-piloto.

Independente da técnica realizada ou do seio maxilar acessado, o procedimento de levantamento do seio maxilar deve ser feito cuidadosamente, principalmente em relação à membrana sinusal, evitando sua perfuração. Além disso, o biomaterial é considerado um importante determinante do sucesso ou falha de um levantamento de seio maxilar, uma vez que os estudos demonstraram que biomateriais no interior do seio maxilar podem estar sujeitos à pressão do ar, responsável também pelo movimento da membrana sinusal (ASAI; SHIMIZU; OOYA, 2002; XU et al., 2004).

\subsection{Dos Resultados}

Neste estudo, através de várias análises, foi observada a capacidade osteocondutora dos substitutos ósseos avaliados, em todos os períodos, complementando estudos prévios ou diferentes modelos estudados previamente, inclusive em seres humanos (PIATTELLI; SCARANO; MANGANO, 1996; SKOGLUND; HISING; YOUNG, 1997; ARTZI, 2001; 
VALENTINI; ABENSUR, 2003; DAVIES et al., 2010; CORDARO et al., 2010; ARAUJOPIRES, 2010; COVANI et al., 2011; CARLO REIS et al., 2011).

Através das tomografias computadorizadas por feixe cônico (TCFC), foi possível constatar a presença do biomaterial ou enxerto ósseo autógeno, a qual foi confirmada em 100\% das amostras. $97,17 \%$ dos espécimes revelaram um aspecto bem circunscrito da região do procedimento de levantamento do seio maxilar e 2,83\% apresentaram aspecto ligeiramente difuso, associado a um velamento entre as partículas. A quantidade de espécimes que revelou velamento no interior do seio maxilar experimental foi de 19,81\%. Como nenhum animal apresentou sinais e sintomas agudos de infecção ou sinusite, a presença do velamento, possivelmente, foi decorrente do sangue que penetrou nas cavidades após a eutanásia, além do material ter permanecido no seu interior, ao longo do tempo, com a membrana intacta. Através da microscopia, foi possível confirmar ausência de processo inflamatório crônico nos espécimes. O velamento, exclusivo dos seios maxilares inferiores, esteve presente em 7,55\% das amostras. A hipótese desse ocorrido foi similar à dos seios experimentais velados ou à da existência de um processo inflamatório crônico. Os achados na TCFC foram correlacionados com as anotações feitas durante o experimento. Dos 7 seios maxilares que sofreram pequena perfuração da membrana (1-2mm), 4 espécimes mostraram velamento, 2 com aspecto difuso, e 3 não apresentaram alterações radiográficas.

Inicialmente, a histomorfometria do tecido ósseo neoformado foi escolhida para ser realizada através do MicroCT, em vez da histomorfometria convencional, realizada em microscópio óptico. A escolha se fez diante da capacidade que o MicroCT possui em reconstruir imagens com ótima resolução, permitir uma análise qualitativa e, consequentemente, calcular o volume ósseo com exatidão. Além disso, quando a análise histomorfométrica convencional é realizada, grande quantidade de cortes e lâminas são necessários para se chegar a um resultado representativo do espécime em estudo. Seria bastante exaustivo, neste estudo, o preparo de um número grande de lâminas a partir de espécimes incluídos em resina, para obter cortes seriados de várias partes do mesmo espécime e, ainda assim, não representar significativamente a amostra. Vale ressaltar que a quantidade de reconstruções microtomográficas acaba sendo 100 vezes ou mais comparada à histomorfometria convencional, quando consideramos um total de 500 reconstruções quantificadas através do MicroCT, neste estudo.

Apesar das vantagens descritas anteriormente, durante a análise quantitativa pelo programa do MicroCT encontrou-se uma dificuldade relacionada com a diferenciação do osso neoformado e as partículas de OsteoScaf ${ }^{\mathrm{TM}}$ (BoneTec Corp - TRT, Toronto, Canadá), devido 
à semelhança do limiar de densidade entre ambos, principalmente no período de 2 semanas. Diante disso, optou-se pela complementação do estudo com outras análises microscópicas para a confirmação ou não dos achados do grupo OsteoScaf ${ }^{\mathrm{TM}}$. Quando a microscopia eletrônica de varredura por retroespalhamento de elétrons (SEM) foi realizada, observamos, nitidamente, a diferença entre o osso e as partículas de OsteoScaf ${ }^{\mathrm{TM}}$. A análise microscópica, após as colorações das lâminas, também confirmou os achados encontrados com a SEM. Diante das observações microscópicas qualitativas, os resultados quantitativos relacionados ao grupo OsteoScaf ${ }^{\mathrm{TM}}$, principalmente no período de 2 semanas, demonstraram menor formação óssea do que quando expressado pelo programa de avaliação do MicroCT. Portanto, apesar de os resultados quantitativos do OsteoScaf ${ }^{\mathrm{TM}}$ pelo MicroCT serem descritos no capítulo de resultados, as conclusões deste trabalho basearam-se nas análises microscópicas. Um outro fator limitante para essa análise foi a distinção entre osso enxertado e osso neoformado no grupo autógeno, tornando inviável a quantificação do volume ósseo, apenas o volume total, o qual foi realizado com a finalidade de se ter uma noção aproximada da reabsorção ou aumento de volume do enxerto, ao longo do tempo. Essa foi a razão de não quantificar, para o grupo autógeno, as demais variáveis quantificadas nos outros grupos. Ainda, a grande variação no formato espacial dos espécimes deve ser considerada, já que não foram quantificadas todas as reconstruções, somente 500 correspondentes à região da janela cirúrgica. Entretanto não foi considerada como uma limitação significante.

As razões que levaram à decisão de quantificar uma sequência selecionada e padronizada de reconstruções microtomográficas por espécime (500) e não quantificar a amostra total, deveu-se, principalmente, ao maior tempo de escaneamento e reconstrução que cada amostra requereria para abranger uma área maior, pois o formato e tamanho do levantamento de seio maxilar, de cada uma, eram bem diferentes entre si e também pelo tempo de trabalho de desenho das 1500-2500 reconstruções para fazer a quantificação total.

Para as demais variáveis analisadas pelo MicroCT, os valores foram cautelosamente estudados na tentativa de compreender a expressão dos resultados. Os resultados microscópicos auxiliaram muito nessa interpretação, que foi influenciada pelos fatores limitantes descritos anteriromente.

Analisando os resultados quantitativos e qualitativos, o substituto ósseo que obteve melhor comportamento osteocondutor foi o Bio-Oss ${ }^{\circledR}$ (Geistlich Biomaterials, Wolhusen, $\mathrm{CH}$, Suíça). Os resultados quantitativos mais importantes do MicroCT, quando abordada esta propriedade, revelaram de forma geral melhor desempenho representado pelo grupo BioOss ${ }^{\circledR}$, como o volume total e ósseo em todos os períodos. Comparando os grupos (Figura 50, 
51), no período de 8 semanas, encontramos o grupo OsteoScaf ${ }^{\mathrm{TM}}$ demonstrando um volume ligeiramente maior. Porém, para concluir os resultados, considerou-se a limitação da análise descrita para este grupo, previamente.

A variável volume total foi calculada através de 500 reconstruções na região média do enxerto, que coincidiu com a janela cirúrgica. O maior volume total em todos os períodos foi representado pelo Bio-Oss ${ }^{\circledR}$ (Figura 50). Considerando a padronização da quantidade de biomaterial preenchido, essa comparação expressou maior volume ósseo para este grupo. Apesar de ter representado um menor valor com 8 semanas, quando comparado aos períodos anteriores, foi o grupo com maior volume total com 8 semanas (Figura 50D). Quando a evolução de volume total, ao longo do tempo, foi avaliada nos outros grupos, observamos uma queda significante do grupo autógeno, evidenciando sua reabsorção, a qual foi confirmada qualitativamente em todas as outras análises. O grupo BoneCeramic $®$ (Instituto Straumann AG, Basel, Suíça), apesar de expressar menores valores de tecido ósseo, em todos os períodos, apresentou uma evolução crescente ao longo do tempo (Figura 51A).

O resultado do número de trabéculas resultou em um pouco de confusão quando foram observados valores mais altos para o grupo BoneCeramic $\AA$, o qual apresentou menor volume ósseo (Figura 53). Entretanto, correlacionando esse resultado com a menor espessura das trabéculas e a microscopia, pode ser esclarecido que diante do menor preenchimento ósseo, as trabéculas se definem mais e, quanto maior a espessura de trabéculas, maior o preenchimento resultando em maior volume ósseo, fato esse ainda melhor interpretado quando observamos que os valores da espessura óssea do Bio-Oss ${ }^{\circledR}$ foram maiores quando comparado ao grupo BoneCeramic, representando maior volume ou preenchimento ósseo (Figura 54). Ainda, quando se avaliou a separação entre as mesmas, Bio-Oss® apresentou os menores valores com 4 e 8 semanas (Figura 55C, 55D).

O único grupo que mostrou uma evolução crescente na espessura de trabéculas foi o Boneceramic $®$. Talvez porque conforme elas foram ganhando espessura, o número de trabéculas foi diminuindo como com 4 e 8 semanas, o que, apesar de ligeiramente maior do que 4 semanas, se apresentou menor que com 2 semanas (Figura 54).

As imagens de SEM e fotomicrografias, após coloração com HE e azul de toluidina, foram fundamentais e demonstraram com precisão os resultados, esclarecendo as dúvidas relacionadas à análise do MicroCT. Em consideração ao grupo OsteoScaf ${ }^{\mathrm{TM}}$, o menor número de trabéculas em todos os períodos pôde ser entendido através da SEM, pois o padrão de neoformação na maior parte do espécime se deu na área de substituição das partículas e entre as mesmas, não apresentando muita definição em sua forma (Figura 53). A espessura, 
provavelmente, foi interpretada pelo programa como um todo (partícula mais tecido ósseo) justificando os valores mais altos relacionados a essa variável (Figura 54). O mesmo ocorreu com a separação entre as trabéculas, a qual se apresentou maior em todos os períodos (Figura 55). Vale ressaltar a importância de considerar os fatores limitantes descritos acima, quando os volumes foram analisados.

$\mathrm{Na}$ tentativa de auxiliar as análises deste estudo e comparar quantitativamente a neoformação óssea em cada período e diferentes áreas do levantamento de seio maxilar, foi proposta a marcação óssea com os fluorocromos: tetraciclina, alizarina e calceína, os quais permitem uma visualização no microscópio confocal e uma quantificação automática deles, através do software AxionVision 40V 4.82.0 (Carl Zeiss MicroImaging GmbH). A metodologia utilizada para essa análise foi baseada em outros estudos bem documentados, com o mesmo propósito, porém que foram aplicados a implantes osseointegráveis (SUZUKI; AOKI; OHYA, 1997; KOO et al., 2004; NISHIKAWA et al., 2006). Para este estudo, utilizou-se um $n=3$, e 3 imagens de cada espécime, em campos diferentes para avaliar uma possível diferença na quantidade de neoformação óssea. Para a aquisição das imagens, os campos foram selecionados aleatoriamente sempre na mesma sequência. Campo 1: janela cirúrgica; Campo 2: região central e Campo 3: área periférica, mais próxima da membrana sinusal. A união dos campos atingiu quase a área total do enxerto, no caso do osso autógeno, ou preenchimento no caso dos biomateriais.

O grupo que demonstrou maior marcação de tetraciclina, no período de 2 semanas, foi o Bio-Oss ${ }^{\circledR}$, seguido do grupo autógeno, OsteoScaf ${ }^{\mathrm{TM}}$ e BoneCeramic ${ }^{\circledR}$. De forma geral, após a tetraciclina ser marcada com 2 semanas, sua expressão foi diminuída em todos os grupos, nos períodos de 4 e 8 semanas, com exceção do grupo BoneCeramic $®$, o qual apresentou maior marcação comparada aos outros grupos, no período de 8 semanas (Figura 84). Esse comportamento sugeriu que houve uma remodelação óssea ao longo do tempo, sendo a marcação obtida com 2 semanas, considerada perdida conforme o osso foi remodelado (Figura 84). O grupo Bio-Oss ${ }^{\circledR}$ apresentou maior expressão na marcação com tetraciclina, correspondendo com os achados das demais análises.

Em relação aos campos estudados, não houve diferença significante no período de 2 semanas. A região mais marcada nos grupos OsteoScaf ${ }^{\mathrm{TM}}$, Bio-Oss ${ }^{\circledR}$ e autógeno foi o campo 3, que corresponde à periferia do enxerto, próximo à membrana sinusal. $\mathrm{O}$ grupo BoneCeramic $\AA$ expressou os menores valores nesse período, inclusive o menor valor correspondente ao campo 3 (Figura 85A). A área central correspondente ao campo 2 ficou intermediária, variando ligeiramente em comparação aos outros campos, em todos os grupos. 
No período de 4 semanas (Figura 85B), os valores da marcação foram reduzidos em todos os grupos, em todos os campos. O grupo OsteoScaf ${ }^{\mathrm{TM}}$ mostrou um predomínio de marcação no campo 2, diferente do Bio-Oss ${ }^{\circledR}$ e autógeno, onde o campo 1 se manteve mais marcado. O campo 3, em todos os grupos, manteve uma marcação importante (Figura 85B). No período de 8 semanas, deu-se a menor expressão de marcação em todos os campos e grupos, porém o grupo BoneCeramic ${ }^{\circledR}$ manteve a maior expressão comparada aos outros grupos (Figura 85C). Analisando os outros períodos, a marcação nesse grupo foi igual ou menor aos outros grupos, somente se manteve constante até 8 semanas (Figura 84). Em relação à distribuição da neoformacão óssea nos 3 campos, foi possível observar uma diversificação entre os grupos e os períodos num mesmo grupo. Diante disso, não foi possível afirmar qual o campo foi mais marcado de uma forma geral, mas considerou-se importante a presença de marcação nas regiões periféricas, representadas pelo campo 3, em todos os grupos, já que as mesmas são mais afastadas da janela cirúrgica.

Os resultados da marcação por alizarina foram menos expressivos quando comparado à tetraciclina, porém esse fato não significou que nesse período houve menor formacão óssea, pois a tetraciclina pode ter maior poder de marcação quando comparada aos outros marcadores deste estudo. Não houve diferença entre os grupos e nem entre os períodos, porém houve diferença entre os campos analisados (Figuras 86, 87). O campo 3 apresentou uma tendência maior de marcação em todos os grupos e períodos (Figura 87). A calceína também não apresentou diferença significante entre os grupos e nem entre os períodos, porém houve diferença entre os campos analisados (Figura 88). A expressão de sua marcação foi inferior quando comparada à tetraciclina, bem similar à expressão de alizarina. Em relação aos campos, houve diferença significante entre as regiões central (2) e periférica (3). O campo 3 mais uma vez se destacou na marcação, enquanto o campo 2 se mostrou com menor frequência de marcação. Vale ressaltar que, microscopicamente, as áreas centrais sempre se apresentaram menos preenchidas por tecido ósseo neoformado.

Este estudo foi pioneiro em comparar o OsteoScaf ${ }^{\mathrm{TM}}$ com outros substitutos ósseos, em cirurgia de levantamento de seio maxilar, porém estudos prévios compararam o comportamento do Bio-Oss ${ }^{\circledR}$ e BoneCeramic ${ }^{\circledR}$, nesse tipo de procedimento. Embora o BioOss ${ }^{\circledR}$, neste estudo, tenha apresentado a maior formação óssea, estudos prévios demonstraram que BoneCeramic ${ }^{\circledR}$ produziu quantidade semelhante ao Bio-Oss®, quando ambos foram usados em levantamento de seio maxilar (CORDARO et al., 2010). Em relação à capacidade osteocondutora, acreditamos que o grupo OsteoScaf ${ }^{\mathrm{TM}}$ foi bastante semelhante ao BoneCeramic $®$, diante de todas as análises qualitativas. 
Nenhum estudo incluindo análise molecular em espécimes submetidos a levantamento de seio maxilar foi encontrado na literatura avaliando os mesmos substitutos ósseos deste estudo, tornando difícil uma comparação de resultados das expressões das variáveis de remodelação óssea, que foram avaliadas (COL1A1, VEGF, RUNX2, BMP2, SPARC e ALPL) e a literatura. Embora a amostra não tivesse sido grande, alguns resultados entre grupos e períodos foram considerados interessantes e um ponto de partida para este tipo de análise nesta metodologia. OsteoScaf ${ }^{\mathrm{TM}}$ apresentou valores bem similares aos outros grupos quando foi avaliada a expressão da maioria das variáveis, sugerindo um comportamento de remodelação óssea compatível com o procedimento. Além disso, com 2 e 4 semanas, a expressão de COL1A1 foi ligeiramente maior que a do Bio-Oss ${ }^{\circledR}$ e BoneCeramic ${ }^{\circledR}$. Este último apresentou menor expressão em todos os períodos (Figura 89). Correlacionando esses achados com o volume ósseo quantificado pelo MicroCT, os resultados parecem apresentar uma correlação positiva. As demais variáveis apresentaram-se bem similares entre os grupos, inclusive sua evolução ao longo do tempo (Figuras 89, 91, 92, 94). Outros achados que valem ser ressaltados, relacionados aos marcadores de remodelação óssea, é que a sua expressão no grupo OsteoScaf ${ }^{\mathrm{TM}}$ foi bem similar aos outros grupos, assim como a variação de expressão com o tempo. A evolução da expressão de COL1A1, RUNX2, BMP-2 e ALPL foi bem similar entre os grupos. A expressão de VEGF, RUNX2, BMP-2, SPARC e ALPL foi bem similar entre os grupos OsteoScaf ${ }^{\mathrm{TM}}$ e Bio-Oss ${ }^{\circledR}$, tanto na quantidade de expressão, quanto sua evolução ao longo do tempo.

Embora as propriedades do OsteoScaf ${ }^{\mathrm{TM}}$ fossem bem demonstradas anteriormente, o objetivo deste estudo foi o de avaliar neste modelo específico, o comportamento de um material totalmente biodegradável e compará-lo com outros dois biomateriais não totalmente biodegradáveis disponíveis no mercado (LICKORISH; GUAN; DAVIES, 2007; DAVIES et al., 2010). É conveniente que os biomateriais possam ser reabsorvidos e totalmente substituídos por tecido ósseo ao longo do tempo. OsteoScaf ${ }^{\mathrm{TM}}$ mostrou nitidamente a maior capacidade de degradação, ao longo do tempo, comparada aos outros grupos. A morfologia e sua degradação foram evidenciadas mais claramente através das análises microscópicas.

Em relação aos substitutos ósseos avaliados neste estudo, Bio-Oss ${ }^{\circledR}$ e BoneCeramic ${ }^{\circledR}$ foram avaliados por diversos autores, anteriormente, em levantamento de seio maxilar, obtendo sucesso (ARTZI et al., 2001; VAENTINI; ABENSUR, 2003; HALMANN et al., 2005; COVANI et al., 2011). Quando clinicamente e microscopicamente avaliados em levantamento de seio em humanos, OsteoScaf ${ }^{\mathrm{TM}}$ mostrou grande desempenho e sucesso clínico (DAVIES et al., 2010). Portanto, a fim de avaliar cuidadosamente a sua eficácia nesse 
procedimento, demonstramos aqui, em modelo experimental e em maior quantidade de análises, o comportamento do OsteoScaf ${ }^{\mathrm{TM}}$, o qual demonstrou claramente a sua capacidade osteocondutora e resultados moleculares bem similares com os demais substitutos ósseos comparados. Foi possível observar, em todos os períodos, a integridade da membrana sinusal após o procedimento, o novo osso circundando as partículas do OsteoScaf ${ }^{\mathrm{TM}}$ e, ainda, crescimento de novo osso entre as partículas degradadas e ausência de resposta inflamatória e células gigantes ao redor do biomaterial. Comparando com os outros biomateriais avaliados neste estudo, a sua capacidade osteocondutora foi bastante semelhante. Ao contrário do OsteoScaf ${ }^{\mathrm{TM}}$, Bio-Oss ${ }^{\circledR}$ e BoneCeramic ${ }^{\circledR}$ não demonstraram degradação ao longo do tempo, apesar de alguns estudos relatarem que eles foram reabsorvidos (PIATTELLI; SCARANO; MANGANO, 1996; DACULSI; GOYENVALLE; AGUADO, 1999). No caso de Bio-Oss®, foi demonstrado ser ele reabsorvido muito lentamente, (PIATTELLI; SCARANO; MANGANO, 1996), enquanto aproximadamente 50\% do BoneCeramic $®$ foi substituído por osso cortical em um ano (DACULSI; GOYENVALLE; AGUADO, 1999).

Apesar deste estudo não ter avaliado a presença de implantes após o levantamento de seio maxilar utilizando o OsteoScaf ${ }^{\mathrm{TM}}$, considerou-se interessante e inédita a comparação da capacidade de degradação entre esses substitutos ósseos. O OsteoScaf ${ }^{\mathrm{TM}}$ apresentou a maior degradação em comparação com os outros grupos, inovando um tipo diferente de substituto ósseo neste modelo experimental. Além disso, reforça estudo anterior (DAVIES et al., 2010), onde esse biomaterial demonstrou ser bastante biodegradável e adequado para o procedimento de levantamento de seio maxilar. 
7 CONCLUSÕES 



\section{CONCLUSÕES}

Através deste estudo foi possível concluir:

- Todos os substitutos ósseos: OsteoScaf ${ }^{\mathrm{TM}}$ (BoneTec Corp - TRT, Toronto, Canadá), Bio-Oss ${ }^{\circledR}$ (Geistlich Biomaterials, Wolhusen, CH, Suíça), BoneCeramic ${ }^{\circledR}$ (Instituto Straumann AG, Basel, Suíça) demonstraram capacidade osteocondutora com 2, 4 e 8 semanas no modelo experimental avaliado.

- OsteoScaf ${ }^{\mathrm{TM}}$ (BoneTec Corp - TRT, Toronto, Canadá) demonstrou capacidade osteocondutora comparável aos outros biomateriais não totalmente biodegradáveis.

- Ao longo do tempo, o osso autógeno demonstrou maior reabsorção óssea.

- Bio-Oss ${ }^{\circledR}$ (Geistlich Biomaterials, Wolhusen, $\mathrm{CH}$, Suíça) demonstrou maior quantidade de neoformação óssea em todos os períodos.

- OsteoScaf ${ }^{\mathrm{TM}}$ (BoneTec Corp - TRT, Toronto, Canadá) foi o substituto ósseo que apresentou maior reabsorção de partículas, embora pudesse observá-las em 8 semanas.

- $\quad$ O OsteoScaf ${ }^{\mathrm{TM}}$ (BoneTec Corp - TRT, Toronto, Canadá) apresentou menor perda de volume total até 8 semanas. 



\section{REFERÊNCIAS}





\section{REFERÊNCIAS}

Al Ruhaimi KA. Bone graft substitutes: a comparative qualitative histologic review of current osteoconductive grafting materials. Int J Oral Maxillofac Implants. 2001;16(1):105-14.

Andrade AL, Domingues RZ. Cerâmicas bioativas: estado da arte. Quím Nova. 2006;29(1):100-04.

Andrade AL. Biomateriais funcionais para reconstrução de tecidos ósseos [tese]. Belo Horizonte (MG): Universidade Federal de Minas Gerais, 2004.

Annabi N, Mithieux SM, Boughton EA, Ruys AJ, Weiss AS, Dehghani F. Synthesis of highly porous crosslinked elastin hydrogels and their interaction with fibroblasts in vitro.

Biomaterials. 2009;30:4550-57.

Apelt D, Theiss F, El-Warrak AO, Zlinszky K, Bettschart-Wolfisbergerb R, Bohner M, et al. In vivo behavior of three different injectable hydraulic calcium phosphate cements.

Biomaterials. 2004;25(7-8):1439-51.

Araújo MG, Carmagnola D, Berglundh T, Thilander B, Lindhe J. Orthodontic movement in bone defects augmented with Bio-Oss ${ }^{\circledR}$. An experimental study in dogs. J Clin Periodontol. 2001;28:73-80.

Araújo MG, Liljenberg B, Lindhe J. beta-Tricalcium phosphate in the early phase of socket healing: an experimental study in the dog. Clin Oral Implants Res. 2010;21(4):445-54.

Araujo MG, Sonohara M, Hayacibara R, Cardaropoli G, Lindhe J. Lateral ridge augmentation by the use of grafts comprised of autologous bone or a biomaterial. An experimente in the dog. J Clin Periodontol. 2002;29:1122-31.

Araujo-Pires A. Avaliação de uma nova matriz tridimensional no processo de reparo de alvéolos dentários em humanos para preservação do rebordo alveolar [tese]. Bauru (SP): Faculdade de Odontologia de Bauru, USP, 2010.

Artzi Z, Nemcovsky CE, Tal H, Dayan D. Histopathological morphometric evaluation of 2 different hydroxyapatite-bone derivatives in sinus augmentation procedures: a comparative study in humans. J Periodontol. 2001;72:911-20.

Asai S, Shimizu Y, Ooya K. Maxillary sinus augmentation model in rabbits: effect of occluded nasal ostium on new bone formation. Clin Oral Impl Res. 2002;13:405-09.

Barone A, Crespi R, Aldini NN, Fine M, Giardino R, Covani U. Maxillary Sinus Augmentation: Histologic and Histomorphometric Analysis. Int J Oral Maxillofac Implants. 2005;20:519-25.

Bell RB, Kindsfater CS. The use of biodegradable plates and screws to stabilize facial fractures. J Oral Maxillofac Surg. 2006;64(1):31-39. 
Bellini OJ. Síntese e caracterização de uma matriz óssea de fosfato de cálcio e nanocompósitos fosfato de cálcio/SiO2 alfa para substituição e regeneração óssea.

[Dissertação de mestrado] Joinville (SC): UDESC, 2007.

Benicewicz B, Hopper P. Polymers for absorbable surgical sutures - Part II. J Bioact Compay Polym. 1991;6:64-94.

Berglundh T, Lindhe J. Healing around implants placed in bone defects treated with BioOss®: An experimental study in the dog. Clin Oral Implants Res. 1997;8:117-20.

Bettega G, Brun J, Boutnnat J, Cracowski J, Quesada J, Hegelhofer H, et al. Autologous platelet concentrates for bone graft enhancement in sinus lift procedure. Transfusion. 2009;49:779-85.

Bil M, Ryszkowska J, Roether JA, Bretcanu O, Boccaccini AR. Bioactivity of polyurethanebased scaffolds coated with Bioglass. Biomed Mater. 2007;2:93-101.

Block MS, Kent JN. Maxillary sinus grafting for totally and partially edentulous patients. J Am Dent Assoc. 1993;124:139.

Block MS, Kent JN. Sinus augmentation for dental implants: the use of autogenous bone. J Oral Maxillofac Surg. 1997;55(11):1281-86.

Boix D, Gauthier O, Guicheux J, Pilet P, Weiss P, Grimandi G, et al. Alveolar bone regeneration for immediate implant placement using an injectable bone substitute: an experimental study. J Periodontol. 2004;75:663-71.

Boschett F, Tomei AA, Turri S, Swartz MA, Levi M. Design, fabrication, and characterization of a composite scaffold for bone tissue engineering. Int J Artif Organs. 2008;31(8):697-07.

Bosetti M, Cannas M. The effect of bioactive glasses on bone marrow stromal cells differentiation. Biomaterials. 2005;26(18):3873-79.

Boyapati L, Wang HL. The role of platelet-rich plasma in sinus augmentation: a critical review. Implant Dent. 2006;15:160-70.

Boyce T, Edwards J, Scarborough N. Allograft bone. The influence of processing on safety and performance. Orthop Clin North Am. 1999;30(4):571-81.

Boyne PJ, James RA. Grafting of the maxillary sinus floor with autogenous marrow and bone. J Oral Maxillofac Surg. 1980;38(8):613-16.

Brånemark PI, Hansson BO, Adell R, Breine U, Lindstrom J, Hallen O, et al. Osseointegrated implants in the treatment of the edentulous jaw. Experience from a 10-year period.

Scandinavian Journal of Plastic and Reconstructive Surgery. Supplementum 1977; 16:1-132.

Brewer NR. Biology of the rabbit. J Am Assoc Lab Anim Sci. 2006;45(1):8-24. 
Browaeys H, Bouvry P, De Bruyn H. A literature review on biomaterials in sinus augmentation procedures. Clin Implant Dent Relat Res. 2007;9(3):166-77.

Buser D, Hoffmann B, Bernard JP, Lussi A, Mettler D, Schenk RK. Evaluation of filling materials in membrane-protected bone defects. A comparative histomorphometric study in the mandible of miniature pigs. Clin Oral Implants Res. 1998;9(3):137-50.

Butterfield KJ, Bennett J, Gronowicz G, Adams D. Effect of platelet-rich plasma with autogenous bone graft for maxillary sinus augmentation in a rabbit model. J Oral Maxillofac Surg. 2005; 63:370-76.

Cancedda R, Dozin B, Giannoni P, Quartzo R. Tissue engineering and cell therapy of cartilage and bone. Matrix Biology. 2003;22:81-91.

Cancian DCJ. Utilização de Biogran ${ }^{\circledR}$ e Calcite ${ }^{\circledR}$ em defectos ósseos. Estudo histológico em macacos Cebus apella. [Dissertação de Mestrado] Araraquara (SP): Faculdade de Odontologia da Universidade Estadual Paulista, 1998.

Canullo L, Dellavia C. Sinus lift using a nanocrystaline hydroxypatite silica gel in severely resorbed maxillae: histological preliminary study. Clin Implant Dent Relat Res. 2009;11:7-13.

Cao W, Hench LL. Bioactive materials. Ceramics Int. 1996;22:493-07.

Cardioli G, Mazzocco C, Schepers E, Brugnolo E, Majzoub Z. Maxillary sinus floor augmentation using bioactive glass granules and autogenous bone with simultaneous implant placement: clinical and histological findings. Clin Oral Implants Res. 2001;12:270-78.

Carlo Reis EC, Borges AP, Araújo MV, Mendes VC, Guan L, Davies JE. Periodontal regeneration using a bilayered PLGA/calcium phosphate construct. Biomaterials. 2011;32(35):9244-53.

Cawood JI. A classification of the edentulous jaws. Int J Oral Maxillofac Surg. 1988;17(4):232-26.

Centers for Disease Control and Prevention (2002) Update: allograft-associated bacterial infections.UnitedStates,2002.MMWR:51(10):207-10.

http://www.cdc.gov/mmwr/preview/mmwrhtml/ mm5110a2.htm

Centers for Disease Control, Prevention (1988) Epidemiologic notes and reports transmission of HIV through bone transplantation: case report and public health recommendations MMWR 37(39):597-9.

http://www.wonder.cdc.gov/wonder/prevguid/m0001284/ m0001284.asp

Chan C, Thompson I, Robinson P, Wilson J, Henchn L. Evaluation of Bioglass/dextran composite as a bone graft substitute. Int J Oral Maxillofac Surg. 2002;31(1):73-77.

Chanavaz M. Maxillary sinus: anatomy, physiology, surgery, and bone grafting related to implantology - eleven years of surgical experience (1979-1990). J Oral Implantol. 1990;16:199-09. 
Chen L, Jiang W, Huang J, He BC, Zuo GW, Zhang W, et al. Insulin-like growth factor 2 (IGF2) potentiates BMP9-induced osteogenic differentiation and bone formation. J Bone Miner Res. 2010;25(11):2447-59.

Chen QZ, Rezwan K, Francon V, Armitage D, Nazhat SN, Jones FH, et al. Surface functionalization of Bioglass ${ }^{\circledR}$-derived porous scaffolds. Acta Biomater. 2007;3(4):551-62.

Conrad EU, Gretch DR, Obermeyer KR, Moogk MS, Sayers M, Wilson JJ, et al. Transmission of the hepatitis-C virus by tissue transplantation. J Bone Joint Surg Am. 1995;77(2):214-24.

Cordaro L, Torsello F, Accorsi Ribeiro C, Liberatore M, Mirisola di Torresanto V. Inlay onlay grafting for three-dimensional reconstruction of the posterior atrophic maxilla with mandibular bone. Int J Oral Maxillofac Surg. 2010;39:350-57.

Cornelini R, Cangini F, Martuscelli G, Wennström J. Deproteinized bovine bone and biodegradable barrier membranes to support healing following immediate placement of transmucosal implants: a short-term controlled clinical trial. Int J Periodontics Restorative Dent. 2004;24(6):555-63.

Correia F, Almeida RF, Costa AL, Carvalho J, Felino A. Levantamento do seio maxilar pela técnica da janela lateral: tipos enxertos. Revista Portuguesa de Estomatologia, Medicina Dentária e Cirurgia Maxilofacial. 2012;53(3):190-96.

Cosso F, Mandia LB, Lenharo A. Elevação do assoalho sinusal associado com o biomaterial "Biogran®" e instalação de implantes osseointegrados. Innovantions J. 2000; 4: 18-21.

Covani U, Orlando B, Giacomelli L, Cornelini R, Barone A. Implant survival after sinus elevation with Straumann ${ }^{\circledR}$ BoneCeramic in clinical practice: ad-interim results of a prospective study at a 15-month follow-up. Clin Oral Implants Res. 2011;22:481-84.

Cruz ACC, Silva JCZ, Pilatti GL, Santos FA. Utilização de vidros bioativos como substitutos ósseos: revisão de literature. Revista de Odontologia da Universidade Cidade de São Paulo. 2006; 18(3)287-95.

Cunniffe GM, Dickson GR, Partap S, Stanton KT, O'Brien FJ. Development and characterisation of a collagen nanohydroxyapatite composite scaffold for bone tissue engineering. J Mater Sci Mater Med. 2010;21(8):2293-98.

Curi MM, Cossolin GS, Koga DH, Araújo SR, Feher O, dos Santos MO, et al. Treatment of avascular osteonecrosis of the mandible in cancer patients with a history of bisphosphonate therapy by combining bone resection and autólogos platelet-rich plasma: Report of 3 cases. J Oral Maxillofac Surg. 2007;65(2):349-55.

Da Silva RF. Estudo de caracterização de pós nanoestruturados de fosfato de cálcio e nanocompósitos fosfato de calico/SiO2n para aplicações biomédicas. [Dissertação de mestrado]. Joinville (SC): UDESC, 2007.

Daculsi G, Goyenvalle E, Aguado E. Spongious and cortical bone substitution kinetics at the expense of macroporous biphasic calcium phosphate: animal and human evidence. In: 
Ohgushi H, Yoshikawa T, Hastings GW, editors. Bioceramics volume 12: Proceedings of the 12th International Symposium on Bioceramics in Medicine. Singapore: World Scientific; 1999; p. 287-29.

Daculsi G, LeGeros RZ, Mitre D. Cristal dissolution of biological and ceramic apatites. Calcif Tissue Int. 1998;45(2)95-103.

Daculsi G, LeGeros RZ, Nery E, Lynch K, Kerebel B. Transformation of biphasic calcium phosphate ceramics in vivo: ultrastructural and physicochemical characterization. J Biomed Mater Res. 1989;23(8):883-94.

Damien CJ, Parsons JR. Bone graft and bone graft substitutes: a review of current technology and applications. J Appl Biomater. 1991;2(3):187-08.

Davies JE, Matta R, Mendes VC, Perri de Carvalho PS. Development, characterization and clinical use of a biodegradable composite scaffold for bone engineering in oromaxillofacial surgery. Organogenesis. 2010;6(3):161-66.

Davies JE. In vivo performance of biodegradable composite particulates (OsteoScafTM) for bone regeneration. III International Congress of Implantology; 2012 setembro 13-15; Bauru, SP.

Dawson E, Mapili G, Erickson K, Taqvi S, Roy K. Biomaterials for stem cell differentiation Adv Drug Deliv Rev. 2008;60(2):215-28.

De Coster P, Browaeys H, De Bruyn H. Healing of extraction sockets filled with BoneCeramic prior to implant placement: preliminary histological findings. Clin Implant Dent Relat Res. 2011;13(1):34-45.

De Oliveira DMP. Síntese e caracterização de pós de fosfato tricálcio- $\beta$ e de hidroxiapatita: elaboração de bifásicos HA/TCP- $\beta$ para aplicações como substituto ósseo. [Dissertação de mestrado]. Joinville (SC): Universidade do Estado de Santa Catarina (UDESC), 2010.

Diès F, Etienne D, Abboud NB, Ouhayoun JP. Bone regeneration in extraction sites after immediate placement of an e-PTFE membrane with or without a biomaterial. A report on 12 consecutive cases. Clin Oral Implants Res. 1996;7(3):277-85.

Dunne M, Corrigan I, Ramtoola Z. Influence of particle size and dissolution conditions on the degradation properties of polylactide-co-glycolide particles. Biomaterials. 2000;21(16):165968.

Dupoirieux L, Pourquier D, Souyris F. Powdered eggshell: a pilot study on a new bone substitute for use in maxillofacial surgery. J Craniomaxillofac Surg. 1995;23(3):187-94.

Ellinger RF, Nery EB, Lynch KL. Histological assessment of periodontal osseous defects following implantation of hydroxyapatite and biphasic calcium phosphate ceramics: a case report. Int J Periodontics Restorative Dent. 1986;6(3):22-33. 
Esposito M, Grusonvin M, Rees J, Karasoulos D, Felice P, Alissa R, et al. Effectiveness of sinus lift procedures for dental implant rehabilitation: a Cochrane systematic reviw. Eur J Oral Implantol. 2010;3:7-26.

Esposito M, Grusovin MG, Felice P, Karatzopoulos G, Worthington HV, Coulthard P. Interventions for replacing missing teeth: horizontal and vertical bone augmentation techniques for dental implant treatment. Cochrane Database of Syst Rev.

2009,7(4):CD003607.

Fedorowicz Z, Nasser M, Newton JT, Oliver RJ. Resorbable versus titanium plates for orthognathic surgery. Cochrane Database Syst Rev. 2007;18(2):CD006204.

Felice P, Antonio S, Pistilli R, Piattelli M, Pellegrino G, Esposito M. A comparison of two techniques to augment maxillary sinuses using the lateral window approach: right synthetic resorbable barriers versus anaorganic bovine bone. Five-month post-loading clinical and histological results of a pilot randomised controlled clinical trial. Eur J Oral Implantol. 2009;2:293-06.

Fernyhough JC, Schimandle JJ, Weigel MC. Chronic donor site pain complicating bone graft harvesting from the posterior iliac crest for spinal fusion. Spine. 1992;17:1474-80.

Fetner AE, Hartigan MS, Low SB. Periodontal repair using Perioglas in nonhuman primates: clinical and histologic observations. Compendium. 1994;15(7):932-8.

Fialkov JA, Holy CE, Shoichet MS, Davies JE. In vivo bone engineering in a rabbit femur. J Craniofac Surg. 2003;14(3):324-32.

Franco-Marques E, Mendez JA, Girones J, Ginebra MP, Pelach MA. Evaluation of the influence of the addition of biodegradable polymer matrices in the formulation of self-curing polymer systems for biomedical purposes. Acta Biomater. 2009;5(8):2953-62.

Froum SJ, Wallace SS, Cho SC, Elian N, Tarnow DP. Histomorphometric comparison of a biphasic bone ceramic to anorganic bovine for sinus augmentation: 6- to 8-month postsurgical assessment of vital bone formation. A pilot study. Int J Periodontics Restorative Dent. 2008;28:273-81.

Froum SJ, Wallace SS, Elian N, Cho SC, Tarnow DP. Comparison of mineralized cancellous bone allograft (Puros) and anorganic bone bovine matrix (Bio-Oss®) for sinus augmentation: histomorphometry at 26 to 32 weeks after grafting. Int J Periodontics Restorative Dent. 2006;26:543-51.

Fuerst G, Tangl S, Gruber R, Gahleitner A, Sanroman F, Watzek G. Bone formation following sinus grafting with autogenous bone-derived cells and bovine bone mineral in minipigs: preliminary findings. Clin Oral Implants Res. 2004;15:733-40.

Fulmer MT, Ison TC, Hankermayer CR, Constanz BR, Ross J. Measurements of solubilities and dissolution rates of several hydroxyapatites. Biomaterials. 2002;23(3):751-55. 
Fürst G, Gruber R, Tangl S, Zechner W, Haas R, Mailath G, et al. Sinus grafting with autogenous platelet-rich plasma and bovine hydroxyapatite. A histomorphometric study in minipigs. Clin Oral Implants Res. 2003;14:500-08.

Furusawa T, Mizunuma K. Osteoconductive properties and efficacy of resorbable bioactive glass as a bone grafting material. Implant Dent. 1997;6(2):93-101.

Gatti AM, Simonetti LA, Monari E, Guidi S, Greenspan D. Bone augmentation with bioactive glass in three cases of dental implant placement. J Biomater Appl. 2006;20:325-39.

Geurs NC, Wang IC, Shulman LB, Jeffcoat MK. Retrospective radiographic analysis of sinus graft and implant placement procedures from the Academy of Osseointegration Consensus Conference on Sinus Grafts. Int J Periodont Restor Dent. 2001;21:517-23.

Giannoudis PV, Dinopoulos H, Tsiridis E. Bone substitutes: an update. Injury. 2005;36 (suppl 3): S20-27.

Girones Molera J, Mendez JA, San Roman J. Bioresorbable and nonresorbable polymers for bone tissue engineering. Curr Pharm Des. 2012;18(18):2536-57.

Gomi K, Kanazashi M, Lickorish D, Arai T, Davies JE. Bone marrow genesis after subcutaneous delivery of rat osteogenic cell-seeded biodegradable scaffolds into nude mice. $\mathrm{J}$ Biomed Mater Res A. 2004;71(4):602-07.

Götz W, Gerber T, Michel B, Lossdörfer S, Henkel KO, Heinemann F. Immunohistochemical characterization of nanocrystalline hydroxyapatite silica gel (NanoBone) osteogenesis: a study on biopsies from human jaws. Clin Oral Implants Res. 2008;19:1016-26.

Grageda E, Lozada JL, Boyne PJ, Caplanis N, McMillan PJ. Bone formation in the maxillary sinus by using platelet-rich plasma: an experimental study in sheep. J Oral Implantol. 2005;31(1):2-17.

Greenwald AS, Boden SD, Goldberg VM, Khan Y, Laurencin CT, Rosier RN. American Academy of Orthopaedic Surgeons. The Committee on Biological Implants. Bone-graft substitutes: facts, fictions, and applications J Bone Joint Surg Am. 2001;83-A Suppl 2 Pt 2:98-103.

Gross V, Brandes J. The ultrastructure of the interface between a glass ceramic and bone. J Biomed Mater Res. 1981;15:291-05.

Guan L, Davies JE. Preparation and characterization of a highly macroporous biodegradable composite tissue engineering scaffold. J Biomed Mater Res A. 2004;71(3):480-87.

Guelcher SA, Srinivasan A, Dumas JE, Didier JE, McBride S, Hollinger JO. Synthesis, mechanical properties, biocompatibility, and biodegradation of polyurethane networks from lysine polyisocyanates. Biomaterials. 2008;29(12):1762-75.

Haas R, Baron M, Donath K, Zecher W, Watzek G. Porous hydroxyapatite for grafting the maxillary sinus: a compara tive histomorphometric study in sheep. Int J Oral Maxillofac Implants. 2002; 17:337-46. 
Haas R, Donath K, Födinger M, Watzek G. Bovine hydroxyapatite for maxillary sinus grafting: comparative findings in sheep. Clin Oral Implants Res. 1998;9:107-66.

Haas R, Mailath G, Dörtbudak O, Watzek G. Bovine hydroxyapatite for maxillary sinus augmentation: analysis of interfacial bond strength of dental implants using pull-out tests. Clin Oral Implants Res. 1998;9:117-22.

Hall EE, Meffert RM, Herman JS, Melloning JT, Cochran DL. Comparison of bioactive glass to demineralized freeze-dried bone allograft in the treatment of intrabony defects around implants in the canine mandible. J Periodontol. 1999;70(5):526-35.

Hallman M, Nordin T. Sinus floor augmentation with bovine hydroyapatite mixed with fibrin glue and later placement of non submerged implants: a retrospective study in 50 patients. Int $\mathbf{J}$ Oral Maxillofac Implants. 2002;19(2):222-27.

Hallman M, Sennerby L, Zetterqvist L, Lundgren S. A 3-year prospective follow-up study of implant-supported fixed prostheses in patients subjected to maxillary sinus floor augmentation with a 80:20 mixture of deproteinized bovine bone and autogenous bone Clinical, radiographic and resonance frequency analysis. Int J Oral Maxillofac Surg. 2005;34:273-80.

Hench LL. Bioactive materials: the potential for tissue regeneration. J Biomed Mater Res. 1998;41(4):511-18.

Henson FMD, Bowe EA, Davies ME. Promotion of the intrinsic damage-repair response in articular cartilage by fibroblastic growth Factor-2. Osteoarthr Cartilage. 2005;13:537-44.

Hirsch JM, Ericsson I. Maxillary sinus augmentation using mandibular bone grafts and simultaneous installation of implants. Clin Oral Implant Res. 1991;2(2):91-96.

Holy CE, Dang SM, Davies JE, Shoichet MS. In vitro degradation of a novel poly(lactide-coglycolide) 75/25 foam. Biomaterials. 1999;20:1177-85.

Holy CE, Shoichet MS, JE Davies. Engineering three-dimensional bone tissue in vitro using biodegradable scaffolds: investigating initial cell-seeding density and culture period. J Biomed Mater Res. 2000;51(3):376-82.

Hu Z, Peel SA, Ho SK, Sándor GK, Su Y, Clokie CM. The expression of bone matrix proteins induced by different bioimplants in a rabbit sinus lift model. J Biomed Mater Res A. 2010;95:1048-54.

Hürzeler MB, Quiñones CR, Kirsch A, Schüpbach P, Krausse A, Strub JR, et al. Maxillary sinus augmentation using different grafting materials and dental implants in monkeys. Part III. Evaluation of autogenous bone combined with porous hydroxyapatite. Clin Oral Implants Res. 1997;8:401-11.

Ishaug-Riley SL, Crane GM, Gurlek A, Miller MJ, Yasko AW, Yaszemski MJ, et al. Ectopic bone formation by marrow stromal osteoblast transplantation using poly(DL-lactic-coglycolic acid) foams implanted into the rat mesentery. J Biomed Mater Res 1997; 36(1):1-8. 
Irinakis T. Rationale for socket preservation after extraction of a single-rooted tooth when planning for future implant placement. J Can Dent Assoc. 2006;72(10):917-22.

Jabbarzadeh E, Starnes T, Khan YM, Jiang T, Wirtel AJ, Deng M, et al. Induction of angiogenesis in tissue-engineered scaffolds designed for bone repair: a combined gene therapy-cell transplantation approach. Proc Natl Acad Sci USA. 2008;105(32):11099-104.

Jain RA. The manufacturing techniques of various drug loaded biodegradable poly(lactide-coglycolide) (PLGA) devices. Biomaterials. 2000;21(23):2475-90.

Jakse N, Tangl S, Gilli R, Berghold A, Lorenzoni M, Eskici A, et al. Influence of PRP on autogenous sinus grafts. An experimental study on sheep. Clin Oral Implants Res.

2003;14(5):578-83.

Jemt T, Lekholm U. Oral implant treatment in posterior partially edentulous jaws: a 5-year follow-up report. Int J Oral Maxillofac Implants.1993;8(6):635-40.

Jensen J, Krantz-Simonsen EK, Sindet-Pedersen S. Reconstruction of the severely resorbed maxilla with bone grafting and osseointegrated implants: A preliminary report. J Oral Maxillofac Surg. 1990;48:27-32.

Jensen J, Sindet-Pedersen S, Oliver AJ. Varying treatment strategies for reconstruction of maxillary atrophy with implants: Results in 98 patients. J Oral Maxillofac Surg. 1994;52(3):210-06.

Jensen J, Sindet-Pedersen S. Autogenous mandibular bone grafts and osseointegrated implants for reconstruction of the severely atrophied maxilla: A preliminary report. J Oral Maxillofac Surg. 1991;49(12):1277-87.

Johnson MW, Sullivan SM, Rohrer M, Collier M. Regeneration of periimplant infrabony defects using PerioGlass: a pilot study in rabbits. Int J Oral Maxillofac Implants. 1997;12(6): 835-39.

Jonh H, Wenz B. Histomorphometric analysis of natural bone mineral for maxillary sinus augmentation. Int J Oral Maxillofac Implants. 2004;19(2):199-07.

Joshi A. An investigation of pos-operative morbidity following chin graft surgery. Br Dent $\mathrm{J}$. 2004;196(4):215-18.

Karp JM, Rzeszutek K, Shoichet MS, Davies JE. Fabrication of precise cylindrical threedimensional tissue engineering scaffolds for in vitro and in vivo bone engineering applications. J Craniofac Surg 2003;14(3):317-23.

Karp JM, Shoichet MS, Davies JE. Bone formation on two-dimensional poly(DL-lactide-coglycolide) (PLGA) films and three-dimensional PLGA tissue engineering scaffolds in vitro. $\mathrm{J}$ Biomed Mater Res A. 2003;64(2):388-96.

Kent JN, Block MS. Simultaneous maxillary sinus floor bone grafting and placement of hydroxylapatite coated implants. J Oral Maxillofac Surg. 1989;47:238. 
Keogh MB, O' Brien FJ, Daly JS. A novel collagen scaffold supports human osteogenesis applications for bone tissue engineering. Cell Tissue Res. 2010;340(1):169-77.

Kleinschmidt JC, Marden LJ, Kent D, Quigley N, Hollinger JO. A multiphase system bone implant for regenerating the calvaria. Plast Reconstr Surg. 1993;91(4):581-88.

Klongnoi B, Rupprecht S, Kessler P, Zimmermann R, Thorwarth M, Pongsiri S, et al. Lack of beneficial effects of platelet-rich plasma on sinus augmentation using a fluorohydroxyapatite or autogenous bone: an explorative study. J Clin Periodontol. 2006;33(7):500-09.

Koch FP, Becker J, Terheyden H, Capsiun B, Wagner W. A prospective, randomized pilot study on the safety and efficacy of recombinant human growth and differentiation factor-5 coated onto ß-tricalcium phosphate for sinus lift augmentation. Clin Oral Impl Res.

2010;21(11):1301-08.

Kohri M, Miki K, Waite DE, Nakajima H, Okabe T. In vitro stability of biphasic calcium phosphate ceramics. Biomaterials. 1993;14(4):299-04.

Kokubo T, Ito S, Huang ZT, Hayashi T, Sakka S, Kitsugi T, et al. CaP-rich layer formed on high-strength bioactive glass-ceramic A-W. J Biomed Mater Res. 1990;24(3):331-43.

Kokubo T, Kim HM, Kawashita M. Novel bioactive materials with different mechanical properties. Biomaterials. 2003;24(13):2161-75.

Kokubo T. Bioactive glass ceramics: properties and applications. Biomaterials. 1991;12(2):155-63.

Koo S, Konig Júnior B, Mizuasaki CI, Allegrini Júnior S, Yoshimoto M, Carbonari MJ. Effects of alcohol consumption on osseointegration of titanium implants in rabbits. Implant Dent. 2004;13:232-37.

Kretlow JD, Young S, Klouda L, Wong M, Mikos AG. Injectable biomaterials for regenerating complex craniofacial tissues. Adv Mater. 2009;21(32-33):3368-93.

Kumlien J, Schiratzki H. The vascular arrangement of the sinus mucosa. A study in rabbits. Acta Otolaryngol 1985;99:122-32.

Kurz LT, Garfin SR, Booth JR. Harvesting autogenous iliac bone grafts: A review of complications and techniques. Spine.1989;14:1324-31.

Lai W, Garino J, Ducheyne P. Silicon excretion from bioactive glass implanted in rabbit bone. Biomaterials. 2002;23:213-17.

Lambert F, Léonard A, Drion P, Sourice S, Layrolle P, Rompen E. Influence of space-filling materials in subantral bone augmentation: blood clot vs. Autogenous bone chips vs. bovine hydroxyapatite. Clin Oral Implants Res. 2011;22:538-45.

Laschke MW, Strohe A, Scheuer C, Eglin D, Verrier S, Alini M et al. In vivo biocompatibility and vascularization of biodegradable porous polyurethane scaffolds for tissue engineering. Acta Biomater. 2009;5(6):1991-01. 
Laughlin RM, Block MS, Wilk R, Malloy RB, Kent JN. Resorbable plates for the fixation of mandibular fractures: a prospective study. J Oral Maxillofac Surg. 2007;65(1):89-96.

Laurencin C, Khan Y, El-Amin SF. Bone graft substitutes. Expert Rev Med Devices. 2006;3:49-57.

Lee SH, Shin H. Matrices and scaffolds for delivery of bioactive molecules in bone and cartilage tissue engineering. Adv Drug Deliv Rev. 2007;59(4-5):339-59.

LeGeros RZ. Calcium phosphate in oral biology and medicine. In: MYERS, H.M. Monographs in oral science. Basel : Karger, 1991. p.210.

LeGeros RZ. Calcium phosphate-based osteoinductive materials. Chemical Reviews. 2008;108:4742-53.

LeGeros RZ. Properties of osteoconductive biomaterials: calcium phosphates. Clin Orthop Relat Res. 2002;395:81-98.

Li J, Wang H. Common implant-related advanced bone grafting complications: classification etiology, and management. Implant Dentistry. 2008;17:389-01.

Lickorish D, Guan L, Davies JE. A three-phase, fully resorbable, polyester/calcium phosphate scaffold for bone tissue engineering: Evolution of scaffold design. Biomaterials. 2007;28(8):1495-02.

Liu X, Ma PX. Polymeric scaffolds for bone tissue engineering, Ann Biomed Eng. 2004;32(3):477-86.

Ludwig SC, Kowalski JM, Boden SD. Osteoinductive bone graft substitutes. Eur Spine J. 2000;9(suppl 1):119-25.

Mankin HJ, Gebhardt MC. Long term results of allograft replacement in the management of bone tumours. Clin Orthop. 1996;324:86-97.

Margolin M, Cogan A, Taylor M, Buck D, McAllister TN, Toth C, et al. Maxillary sinus augmentation in the non-human primate: a comparative radiographic and histologic study between recombinant human osteogenic protein-1 and natural bone mineral. J Periodontol. 1998; 69(8):911-19.

Marukawa K, Ueki K, Okabe K, Nakagawa K, Yamamoto E. Use of self-setting $\alpha$-tricalcium phosphate for maxillary sinus augmentation in rabbit. Clin Oral Implants Res. 2011;22:60612.

Marx RE, Saunders TR: Reconstruction and rehabilitation of cancer patients, in Fonseca RJ, Davis WH (eds): Reconstructive Preprosthetic Oral and Maxillofacial Surgery. Philadelphia, PA, Saunders, 1986, p. 347-428.

Marx RE. Platelet-rich plasma: evidence to support its use. J Oral Maxillofac Surg. 2004;62(4):489-96. 
Marx RE. The science and art of reconstructing the jaws and temporomandibular joints, in Bell WH (ed): Modern Practice in Orthognathic and Reconstructive Surgery. Philadelphia, PA, Saunders, 1992, p. 1449-52.

McAllister B, Margolin M, Cogan A, Buck D, Hollinger J, Lynch S. Eighteen-month radiographic and histologic evaluation of sinus grafting with anorganic bovine bone in the chimpanzee. Int J Oral Maxillofac Implants. 1999;14:361-68.

Misch C. Maxillary sinus augmentation for endosteal implants: organized alternative treatment plans. Int J Oral Implantol. 1987;4:49-58.

Misch CE, Dietsh F. Bone graft materials in implant dentistry. Implant Dent. 1993;2(3):15867.

Miyazaki M, Tsumura H, Wang JC, Alanay A. An update on bone substitutes for spinal fusion. Eur Spine J. 2009;18(6):783-99.

Molera JG, Mendes JA, San Roman J. Bioresorbable and nonresorbable polymers for bone tissue. Curr Pharm Des. 2012;18:2536-57.

Moore WR, Graves SE, Bain GI. Synthetic bone graft substitutes. ANZ Journal of Surgery. 2001;71:354-61.

Moy PK, Lundgren S, Homes RE. Maxillary sinus augmentation: Histomorphometric analysis of graft materials for maxillary sinus floor augmentation. J Oral Maxillofac Surg.

1993;51(8):857-62.

Mulliken JB, Glowacki J. Induced osteogenesis for repair and construction in the craniofacial region. Plast Reconstr Surg. 1980;65(5):553-60.

Muschler GF, Lane JM. Orthopedic surgery. In: Habal MB, Reddi AH. Bone Grafts and Bone Substitutes. Philadelphia: W. B. Saunders. 1992; 375-407.

Muzzarelli RAA. Chitosan composites with inorganics, morphogenetic proteins and stem cells, for bone regeneration. Carbohydr Polym. 2011;83(4):1433-45.

Nishikawa T, Masuno K, Mori M, Tajime Y, Kakudo K, Tanaka A. Calcification at the interface between titanium implants and bone: Observation with confocal laser scanning microscopy. J Oral Omplant. 2006;32(5):211-17.

Nkenke E, Stelzle F. Clinical outcomes of sinus floor augmentation for implant placement using autogenous bone or bone substitutes: a systematic review. Clin Oral Implants Res. 2009;20(4):124-33.

Ohya M, Yamada Y, Ozawa R, Ito K, Takahashi M, Ueda M. Sinus floor elevation applied tissue-engineered bone. Comparative study between mesenchymal stem cells/platelet-rich plasma (PRP) and autogenous bone with PRP complexes in rabbits. Clin Oral Implants Res. 2005;16:622-29. 
Osborn JF, Newesely H. The material science of calcium phosphate ceramics. Biomaterials. 1980;1(2):108-11.

Patterson J, Siew R, Herring SW, Lin ASP, Guldberg, R, Stayton, PS. Hyaluronic acid hydrogels with controlled degradation properties for oriented bone regeneration. Biomaterials. 2010;31(26):6772-81.

Perry CR. Bone repair techniques, bone graft, and bone grafts substitutes. Clin Orthop Relat Res. 1999;(360):71-86.

Piattelli A, Scarano A, Mangano C. Clinical and histologic aspects of biphasic calcium phosphate ceramic (BCP) used in connection with implant placement. Biomaterials. 1996;17:1767-70.

Pikdöken 1, Gürbüzer B, Kücükodaci Z, Urban M, Baris, E, Tezulas, E. Scintigraphic, Histologic, and Histomorphometric Analyses of Bovine Bone Mineral and Autogenous Bone Mixture in Sinus Floor Augmentation: A Randomized Controlled Trial- Results After 4 Months of Healing. J Oral Maxillofac Surg. 2011;69:160-9.

Pjetursson BE, Tan WC, Zwahlen M, Lang NP. A systematic review of the success of sinus floor elevation and survival of implants inserted in combination with sinus floor elevation. $\mathrm{J}$ Clin Periodontol. 2008;35(8):216-40.

Puppi D, Chiellini F, Piras AM, Chiellini E. Polymeric materials for bone and cartillage repair. Progress Polym Sci. 2010;35:403-40.

Quiñones CR, Hürzeler MB, Schüpbach P, Arnold DR, Strub JR, Caffesse RG. Maxillary sinus augmentation using different grafting materials and osseointegrated dental implants in monkeys. Part II. Evaluation of porous hydroxyapatite as a grafting material. Clin Oral Implants Res. 1997;8(6):487-96.

Rachmiel A, Aizenbud D, Peled M. Enhancement of bone formation by bone morphogenetic protein-2 during alveolar distraction: an experimental study in sheep. J Periodontol. 2004;75(11):1524-31.

Raghoebar GM, Louwerse C, Kalk WWI, Vissink A. Morbidity of chin bone harvesting. Clin Oral Implant Res. 2001;12(5):503-07.

Raja SV. Management of the posterior maxilla with sinus lift: review of techniques. J Oral Maxillofac Surg. 2009;67(8):1730-34.

Reich KM, Huber CD, Lippnig WR, Ulm C, Watzek G, Tangl S. Atrophy of the residual alveolar ridge following tooth loss in an historical population. Oral Dis. 2011 Jan;17(1):3344.

Rezwan K, Chen QZ, Blaker JJ, Boccaccini AR. Biodegradable and bioactive porous polymer/inorganic composite scaffolds for bone tissue engineering. Biomaterials. 2006;27(18):3413-31. 
Roldàn J, Jepsen S, Schmidt C, Knüppel H, Rueger DC, Açil Y, et al. Sinus floor augmentation with simultaneous placement of dental implants in the presence of platelet-rich plasma or recombinant human bone morphogenetic protein-7. Clin Oral Implants Res. 2004;15(6):716-23.

Salgado AJ, Coutinho OP, Reis RL, Davies JE. In vivo response to starch-based scaffolds designed for bone tissue engineering applications. J Biomed Mater Res A. 2007;80(4):983-9.

Sbordone L, Toti P, Menchini-Fabris GB, Sbordone C, Piombino P, Guidetti F. Volume changes of autogenous bone grafts after alveolar ridge augmentation of atrophic maxillae and mandibles. Int J Oral Maxillofac Surg. 2009;38:1059-65.

Schaaf H, Streckbein P, Lendeckel S, Heidinger KS, Rehmann P, Boedeker R, et al. Sinus lift augmentation using autogenous bone grafts and platelet-rich plasma: radiographic results. Oral Surg Oral Med Oral Pathol Oral Radiol Endod. 2008;106:673-78.

Scharf KE, Lawson W, Shapiro JM, Gannon PJ. Pressure measurements in the normal and occluded rabbit maxillary sinus. Laryngoscope. 1995;105:570-74.

Schepers E, Barbier L, Ducheyne P. Implant placement enhanced by bioactive glass particles of narrow size range. Int J Oral Maxillofac Implants. 1998;13(5):655-65.

Schepers E, de Clercq M, Ducheyne P, Kempeneers R. Bioactive glass particulate material as a filler for bone lesions. J Oral Rehabil. 1991;18(5):439-52.

Schepers E, Pinruethai PA comparative study of bioactive glass and porous hydroxylapatite particles in periodontal bone lesions. In: Ducheyne P, Christiansen D, editors. Bioceramics. Proceedings of the 6th International Symposium on Ceramics in Medicine. Boston: Butterworth-Heinemann Ltd.; 1993. p. 113-6.

Schimming R, Schelzeisen R. Tissue-engineered bone for maxillary sinus augmentation. J Oral Maxillofacial Surg. 2004;62(6):724-29.

Schlegel K, Fichtner G, Mosgau S, Wiltfang J. Histologic findings in sinus augmentation with autogenous bone chips versus a bovine bone substitute. Int J Oral Maxillofac Implants. 2003;18:53-58.

Schmidt MB, Chen EH, Lynch SE. A review of the effects of insulinlike growth factor and platelet derived growth factor on in vivo cartilage healing and repair. Osteoarthr Cartilage. 2006;14:403-12.

Schmitt JM, Buck DC, Joh SP, Lynch SE, Holinger JO. Comparison of porous bone mineral and biologically active glass in critical-sized defects. J Periodontol. 1997; 69(11):1312-14.

Schmitz JP, Hollinger JO. The biology of platelet-rich plasma. J Oral Maxillofac Surg. 2001;59(9):1119-21.

Schwartz Z, Goldstein M, Raviv E, Hirsch A, Ranly DM, Boyan BD. Clinical evaluation of demineralized bone allograft in a hyaluronic acid carrier for sinus lift augmentation in 
humans: a computed tomography and histomorphometric study. Clin Oral Implants Res. 2007;18(2):204-11.

Schwartz C, Liss P, Jacquemaire B, Lecestre P, Frayssinet P. Biphasic synthetic bone substitute use in orthopaedic and trauma surgery: clinical, radiological and histological results. J Mater Sci Mater Med. 1999;821-25.

Sharpe JR, Sammons RL, Marquis PM. Effect of $\mathrm{pH}$ on protein adsorption to hydroxyapatite and tricalcium phosphate ceramics. Biomaterials. 1997;18(6):471-76.

Shea LD, Wang D, Franceschi RT, Mooney DJ. Engineered bone development from a preosteoblast cell line on three-dimensional scaffolds. Tissue Eng. 2000;6(6):605-17.

Shimizu Y, Sugawara H, Furusawa T, Mizunuma K, Inada K, Yamashita S. Bone remodeling with resorbable bioactive glass and hydroxyapatite. Implant Dent. 1997;6(4):269-74.

Sicca CM, Corotti MV, Sgarbosa SH, Cestari TM, Cavalcanti MG, Ferreira PM, et al. Comparative histomorphometric and tomographic analysis of maxillary sinus floor augmentation in rabbits using autografts and xenografts. J Biomed Mater Res B Appl Biomater 2008;86:188-96.

Silva FM, Albergaria-Barbosa J, Mazzonetto R. Clinical Evaluation of Association of Bovine Bone Morphogenetic Protein Versus Autogenous Bone Graft in Sinus Floor Augmentation. J Oral Maxillofac Surg. 2006;64:931-35.

Skoglund A, Hising P, Young C. A clinical and histologic examination in humans of the osseous response to implanted natural bone mineral. Int J Oral Maxillofac Implants. 1997;12(2):194-99.

Sohn DS, Kim WS, An KM, Song KJ, Lee JM, Mun YS. Comparative histomorphometric analysis of maxillary sinus augmentation with and without bone grafting in rabbit. Implant Dent. 2010;19:259-70.

Somanathan R, Simunek A. Evaluation of the success of Tricalciumphosphate and deproteinezed bovine bone in maxillary sinus augmentation using histomorphometry: A review. Acta Medica. 2006;49:87-89.

Stevenson S. Biology of bone grafts. Orthop Clin North Am. 1999;30(4):543-52.

Strnad Z. Role of glass phase in bioactive glass-ceramics. Biomaterials. 1992;13(5):317-21.

Sun XJ, Zhang ZY, Wang SY, Gittens SA, Jiang XQ, Chou LL. Maxillary sinus floor elevation using a tissue-engineered bone complex with OsteoBone and bMSCs in rabbits. Clin Oral Implants Res. 2008;19:804-13.

Suzuki K, Aoki K, Ohya K. Effects of surface roughness of titanium implants on bone remodeling activity of fêmur in rabbits. Bone. 1997;21:507-514.

Tadjoedin ES, Lange GL, Lyaruu DM, Kuiper L, Burger EH. High concentrations of bioactive glass material (Biogran ${ }^{\circledR}$ ) vs. autogenous bone for sinus floor elevation. 
Histomorphometrical observations on three split mouth clinical cases. Clin Oral Impl Res. 2002;13:428-36.

Tamimi FM, Torres J, Tresguerres I, Clemente C, López-Cabarcos E, Blanco LJ. Bone augmentation in rabbit calvariae: comparative study between Bio-Oss and a novel bTCP/DCPD granulate. J Clinical Periodontology. 2006;33:922-28.

Tan WC, Lang NP, Zwahlen M, Pjetursson BE. A systematic review of the success of sinus floor elevation and survival of implants inserted in combination with sinus floor elevation.

Part II: transalveolar technique. J Clin Periodontol. 2008;35(8):241-54.

Tatum OH. Maxillary and sinus implant reconstruction. Dental Clinics of North America. 1986;30:207-29.

Tay BK, Patel VV, Bradford DS. Calcium sulfate- and calcium phosphate-based bone substitutes. Mimicry of the mineral phase of bone. Orthop Clin North Am. 1999;30(4):61523.

Terheyden H, Jepsen S, Möller B, Tucker M, Rueger D. Sinus floor augmentation with simultaneous placement of dental implants using a combination of deproteinized bone xenografts and recombinant human osteogenic protein-1. Clin Oral Implants Res. 1999; 10:510-21.

Thorwarth M, Srour S, Felszeghy E, Kessler P, Scultze-Mosgau S, Schlegel K. Stability of autogenous bone grafts sinus lift procedures: A comparative study between anterior and posterior aspects of the iliac and an intraoral donor site. Oral Surg Oral Med Oral Pathol Oral Radiol Endod. 2005;100:278-84.

Tomford WW. Transmission of disease through transplantation of musculoskeletal allografts. J Bone Joint Surg Am. 1995;77(11):1742-54.

Tong DC, Rioux K, Drangsholt M, Beirnem OR. A review of survival rates for implants placed in grafted maxillary sinuses using meta-analysis. Int J Oral Maxillofac Implants. 1998;13(2):175-82.

Torres J, Tamimi F, Martinez P, Alkraisat MH, Linares R. Effect of platelet-rich plasma on sinus lifting: a randomizes-controlled clinical trial. J Clin Periodontol. 2009;36:677-87.

Tosoulis G, Yao S, Fine J. The maxillary sinus: challenges and treatments for implant placement. Compendium. 2011;32:10-20.

Turunen T, Peltola J, Helenius H, Yli Urpo, Happonen RP. Bioactive glass and calcium carbonate granules as filler material around titanium and bioactive glass implants in the medullar space of the rabbit tibia. Clin Oral Implants Res. 1997;8(2):96-102.

Ueda M, Tohnai I, Nakai H. Tissue engineering research in oral implant surgery. Artif Organs. 2001;25(3):164-71.

Urist MR, Mikulski A, Lietze A. Solubilized and insolubilized bone morphogenetic protein. Proc Natl Acad Sci USA. 1979;76(4):1828-32. 
Valentini P, Abensur DJ. Maxillary sinus grafting with anorganic bovine bone: a clinical report of long-term results. Int J Oral Maxillofac Implants. 2003;18(4):556-60.

Van den Bergh JP, Ten Bruggenkate CM, Disch FJ, Tuinzing DB. Anatomical aspects of sinus floor elevations. Clin Oral Impl Res. 2000;11:256-65.

Van der Weijden F, Dell'Acqua F, Slot DE. Alveolar bone dimensional changes of postextraction sockets in humans: a systematic review. J Clin Periodontol. 2009;36(12):1048-58.

Verhoeven JW, Ruijter J, Cune MS, Terlou M, Zoon M. Onlay grafts in combination with endosseous implants in severe mandibular atrophy: one year results of a prospective, quantitative radiological study. Clin Oral Implants Res. 2000;11:583-94.

Vertenten G, Lippens E, Gironès J, Gorski T, Declercq H, Saunders J, et al. Evaluation of an injectable, photopolymerizable, and three-dimensional scaffold based on methacrylateendcapped poly(D,L-lactide-co-epsilon-caprolactone) combined with autologous mesenchymal stem cells in a goat tibial unicortical defect model. Tissue Eng Part A. 2009;15(7):1501-11.

Vogel M, Voigt C, Epros M, Müller-Mai CM. In vivo comparison of bioactive glass particle in rabbits. Biomaterials. 2001;22(4):357-62.

Wada K, Niimi A, Watanabe K, Sawai T, Ueda M. Maxillary sinus floor augmentation in rabbits: a comparative histologic-histomorphometric study between rhBMP-2 and autogenous bone. Int J Periodontics Restorative Dent. 2001;21:252-63.

Waris V, Waris E, Sillat T, Konttinen YT. BMPs in periprosthetic tissues around aseptically loosened total hip implants. Acta Orthop. 2010;81(4):420-26.

Watanabe K, Niimi A, Ueda M. Autogenous bone grafts in the rabbit maxillary sinus. Oral Surg Oral Med Oral Pathol Oral Radiol Endod. 1999;88:26-32.

Wetzel A, Stich H, Caffesse R. Bone apposition onto oral implants in the sinus area filled with different grafting materials. Clin Oral Implants Res. 1995;6:155-63.

Wheeler DL, Stokes KE, Hoelbrich RG, Chamberland DL, McLoughlin SW. Effect of bioactive glass particle size on osseous regeneration of cancellous defects. J Biomed Mater Res. 1998; 41(4):527-33.

Wheeler DL, Stokes KE, Park HM, Hollinger JO. Evaluation of particulate Bioglass in a rabbit radius ostectomy model. J Biomed Mater Res. 1997,35(2):249-54.

Wheeler SL. Sinus augmentation for dental implants: the use of alloplastic materials. J Oral Maxillofac Surg. 1997;55:1287-93.

Whittaker JM, James RA, Lozada J, Cordova C, GaRey DJ. Histological response and clinical evaluation of autograft and allograft materials in the elevation of the maxillary sinus for the preparation of endosteal dental implant sites. Simultaneous sinus elevation and root form implantation: An eight month autopsy report. J Oral Implantol. 1989;15(2):141-44. 
Willie BM, Petersen A, Schmidt-Bleek K, Cipitria A, Mehta M, Strube P et al. Designing biomimetic scaffolds for bone regeneration: why aim for a copy of mature tissue properties if nature uses a different approach? Soft Matter. 2010;6(20):4976-87.

Wiltfang J, Schulteze-Mosgau S, Nkenke E, Thorwarth M, Neukam F, Schlegel K. Only augmentation versus sinuslifht procedure in the treatment of the severely resorbed maxilla: a 5-year comparative longitudinal study. Int J Oral Maxillofac Surg. 2005;34:885-89.

Wise SG, Mithieux SM, Weiss AS. Engineered Tropoelastin and Elastin-Based Biomaterials. Adv Prot Chem Struct Biology. 2009;78:1-24.

Xu C, Su P, Chen XF, Meng Y, Yu W, Xiang AP, et al. Biocompatibility and osteogenesis of biomimetic Bioglass-Collagen- Phosphatidylserine composite scaffolds for bone tissue engineering. Biomaterials. 2011;32(4):1051-58.

Xu H, Shimizu Y, Asai S, Ooya K. Experimental sinus grafting with the use of deproteinized bone particles of different sizes. Clin Oral Implants Res. 2003;14:548-55.

Xu H, Shimizu Y, Asai S, Ooya K. Grafting of deproteinized bone particles inhibits bone resorption after maxillary sinus floor elevation. Clin Oral Implants Res. 2004;15:126-33.

Yildirim M, Spiekermann H, Biesterfeld S, Edelhoff D. Maxillary sinus augmentation using xenogenic bone substitute material Bio-Oss in combination with venous blood. A histologic and histomorphometric study in humans. Clin Oral Implants Res. 2000;11:217-29.

Younger EM, Chapman MW. Morbidity at bonegraft donor sites. J Orthop Trauma. 1989;3(3):192-95.

Zaffe D, Leghissa GC, Pradelli J, Botticelli AR. Histological study on sinus lift grafting by fisiograft and Bio-Oss. Journal of Materials Science. 2005;16(9):789-93.

Zawadzak E, Bil M, Ryszkowska J, Nazhat SN, Cho J, Bretcanu O, et al. Polyurethane foams electrophoretically coated with carbon nanotubes for tissue engineering scaffolds. Biomed Mater. 2009;4(1): 015008.

Zijderveld SA, Schulten EA, Aartman IH, ten Bruggenkate CM. Long-term changes in graft height after maxillary sinus floor elevation with different grafting materials: radiographic evaluation with a minimum follow-up of 4.5 years. Clinical Oral Implants Research. 2009;20:691-00.

Zitzmann NU, Schärer P. Sinus elevation procedures in the resorbed posterior maxilla. Comparison of the crestal and lateral approaches. Oral Surg Oral Med Oral Pathol Oral Radiol Endod. 1998;85(1):8-17. 
Anexos 



\section{ANEXOS}

ANEXO A - Aprovação do Projeto pelo comitê de Ética em Pesquisa da FOB/USP

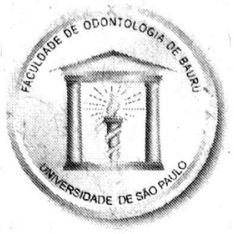

\section{Universidade de São Paulo Faculdade de Odontologia de Bauru}

Al. Dr. Octávio Pinheiro Brisolla, 9-75 - Bauru-SP - CEP 17012-901 - C.P_73

PABX (0XX14)3235-8000 - FAX (0XX14)3223-4679

Comisså̃o de Ética no Ensino e Pesquísa em Animais Fone: (14)3235-8356

e-mail: mferrari@fob.usp.br

CEEPA-Proc. № 015/2010

Bauru, 22 de junho de 2010.

Senhor Professor,

O projeto de pesquisa encaminhado a esta Comissão de Ética no Ensino e Pesquisa em Animais, denominado "Avaliação da utilização do OSTEOSCAF ${ }^{\mathrm{TM}}$ como material para enxerto em seio maxilar de coelhos", de autoria de Camila Lopes Cardoso, foi enviado ao relator para avaliação.

O parecer do Relator aprovando o projeto foi aceito "ad referendum" desta Comissão, considerando. não haver impedimentos éticos.

Atenciosamente,

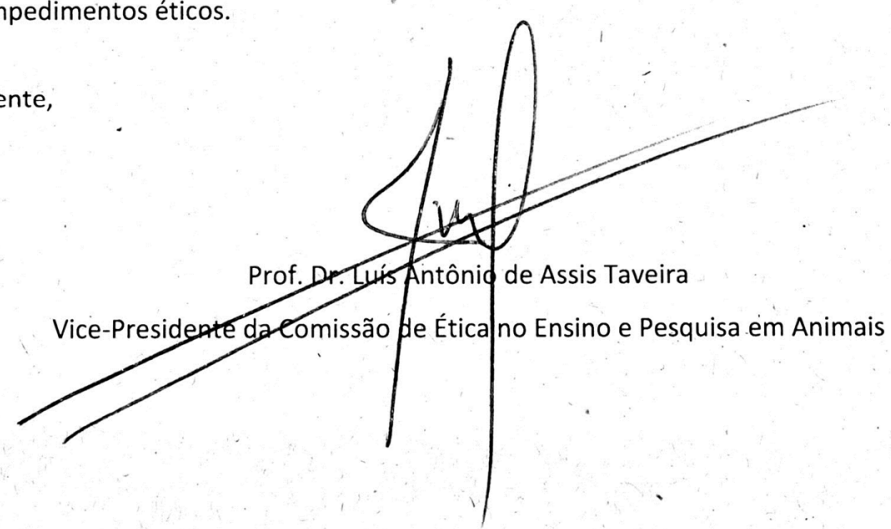

Prof. Dr. Osny Ferreira Júnior

Docente do Departamento de Estomatologia 
ANEXO A - Aprovação do Projeto pelo comitê de Ética em Pesquisa da FOB/USP

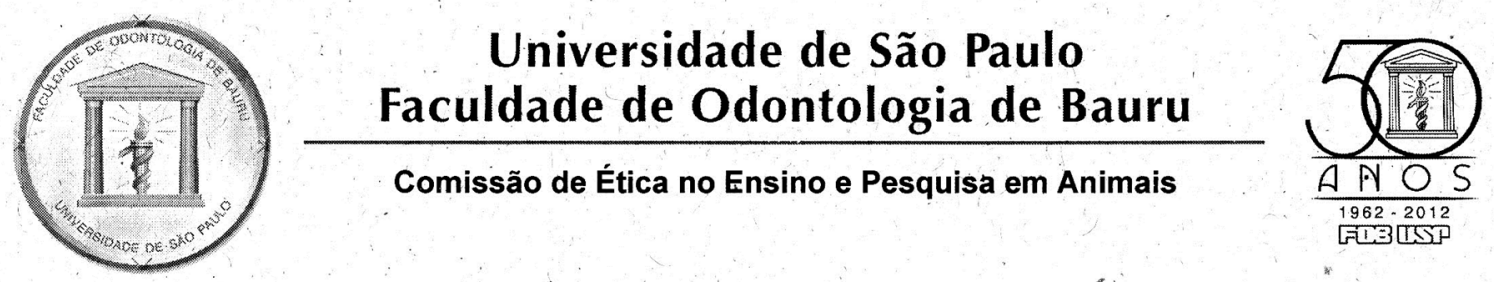

CEEPA-Proc. № 015/2010

Bauru, 23 de janeiro de 2013.

Senhor Professor

Em atenção à solicitação de alteração no título do projeto de pesquisa "Avaliação da utilização do OSTEOSCAFTM como material para enxerto em seio maxilar de coelhos", para ANÁLISE DA UTILIZAÇÃO DO OSTEOSCAFT COMO SUBSTITUTO ÓSSEO EM CIRURGIA DE LEVANTAMENTO DE SEIO MAXILAR, desenvolvido por Camiła Lopes Cardoso, sob sua orientação, informamos a aprovação ad referendum desta Comissão, considerando não haver impediméntos éticos.

Atenciosamente

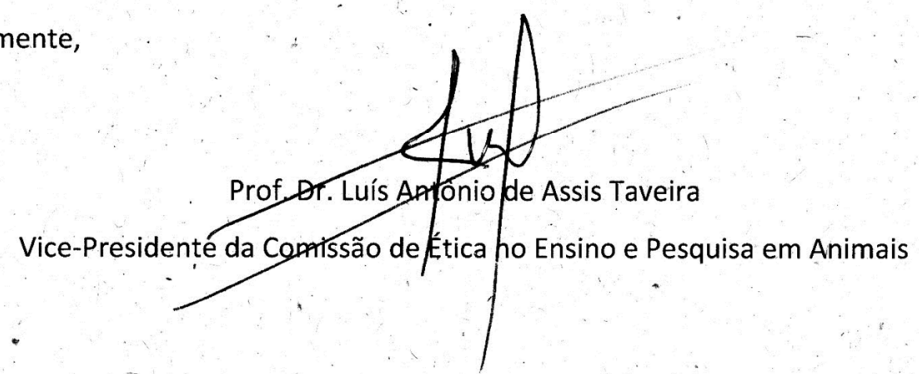

Prof. Dr. Osny Ferreira Júnior

Docente do Departamento de Estomatologia

Al. Dr. Octávio' Pinheiro Brisolla, 9-75 - Bauru-SP - CEP 17012-101 - C.P. 73

e-mail: mferrari@fob.usp.br -Fone/FAX (0xx14) 3235-8356

http://www.fob.usp.br 
ANEXO B - Declaração CAPES referente ao estágio no Exterior

Coordenacto de Aperfelcoamento de Pessoal de Nivel Superlor Setor Bancirio Norte, Quadra 2, Bloce L, Lote 06

70040.020 - Brasilia, DI

Brasil

\section{A QUEM INTERESSAR POSSA}

Declaramos, para os devidos fins, que o(a) interessado(a) abaixo, foi bolsista da Capes e realizou Estágio de doutorando no Exterior, por meio do Programa de Doutorado no País com Estágio no Exterior - PDEE.

BOLSISTA: CAMILA LOPES CARDOSO

PERIODO DA BOLSA: 07/2011 a 03/2012

INSTITUIÇÃO: UNIVERSITY OF TORONTO

PAÍS: CANADA

ÁREA: CIRURGIA BUCO-MAXILO-FACIAL.

Brasilia, 24 de Abril de 2012

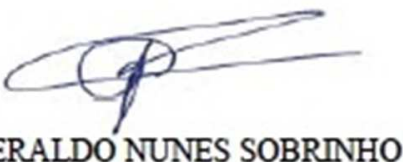

Coordenador-Geral de Bolsas no Exterior 
ANEXO B - Relatório do orientador do estágio no Exterior

Institute of Biomaterials

\& Biomedical Engineering

UNIVERSITY OF TORONTO

CAPES - Coordenação de Aperfeiçoamento de Pessoal de Nivel Superior

Setor Bancário Norte, Quadra 2, Bloco L, Lote 06

Caixa Postal $25070040-020$

Brasília, DF

Brasil

24th February 2012

To whom it may concern:

Re: Camila Cardoso

I am delighted to write this letter confirming that Camila Lopes Cardoso worked in my laboratories at the University of Toronto, from 28th June 2011 to 31st March 2012, as a visiting PhD student supported by a CAPES scholarship.

Camila's PhD project focuses on comparing the tissue reaction to a novel bone substitute material, Osteoscaf ${ }^{\mathrm{T}}$ ' developed in my laboratories, with three other materials, autogenous bone, BioOss ${ }^{\mathrm{TM}}$ and Bone Ceramic ${ }^{\mathrm{Tm}}$, implanted during sinus lift procedures in rabbits. She created the surgical defects by employing an anterior approach to the rabbit maxillary sinus, gently lifted the Scheiderian membrane, then inserted a known volume of material. The reason for the experiment, and tissue reaction comparisons, was than unlike BioOss ${ }^{T M}$ and Bone Ceramic ${ }^{T M}$, OsteoScaf ${ }^{T M}$ is fully, and rapidly, biodegradable and could thus be less efficient in increasing bone volume compared to the ceramic-like materials, as has been previously been shown for autogenous bone. All the surgical work was undertaken in Department of Stomatology, Bauru School of Dentistry, University of São Paulo, and she brought a total of 108 biopsy samples to Toronto. Thus, her work here was dedicated to the analysis of these biopsies generated at the Bauru School of Dentistry. Her work in Brazil was supervised by Prof. Dr. Osny Ferreira Júnior.

Since her arrival in Toronto, and throughout her stay with us, Camila has worked tirelessly to examine the large sample cohort. She has undertaken extensive microCT together with some resin and wax embedded histology, and scanning electron microscopy including back-scattered electron imaging. Camila has shown great initiative in successfully deriving microCT gating methods to distinguish between OsteoScaf ${ }^{\mathrm{T}}$ and reparative bone, although they have very similar radio-densities, which will be of lasting benefit to our research group efforts here and, I trust, those that follow-on from her work in Brazil.

Faculties of applied Science and Engineering, Medicine, and Dentistry Rosebrugh Building. 164 College Street, Room 407. Toronto. ON M5S 3G9 Canada 
Institute of Biomaterials

\& Biomedical Engineering

UNIVERSITY OF TORONTO

Camila's project work with us has, as a direct result of her continuous hard work, been a considerable success. Her observations show that OsteoScaf'm outperformed autogenous bone and generated similar tissue volumes to both BioOss ${ }^{\mathrm{TM}}$ and Bone Ceramic $^{\text {Tw }}$ but without the disadvantages associated with the very slow degradation of the later. Furthermore, her work has clearly illustrated the florid giant cell response that can be witnessed with high temperature sintered materials with sharp geometric features - a finding that should be of considerable interest in the clinical field of maxillafacial surgery. The data are therefore both unique and a testament to the hard work she has undertaken during her visit to Toronto.

On a personal level, Camila has interacted extremely well with everyone else in the group. She has used this opportunity to radically improve her spoken English, which is now very good. As Camila returns to Brazil, we have planned a manuscript based on her data; a paper that will be submitted to a high impact peer-reviewed journal, and represent our active and productive collaboration between Bauru School of Dentistry and UoT.

In short, Camila, has shown herself to be an excellent visiting PhD student - productive, energetic, dedicated, professional and personable. We look forward to a lasting collaboration as she continues her work in Brazil.

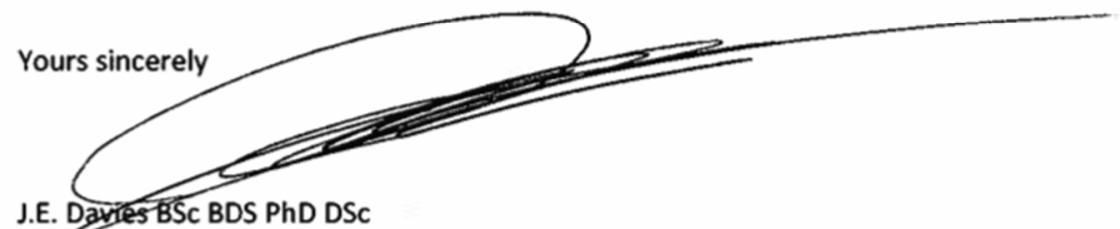

Protessor of Biomaterials

Direct Phone: 416 978-1471

Private Fax: 416 946-5639

Faculties of Applied SCience and Engineering, Medicine, and Dentistry 
ANEXO C - Tabelas referentes ao capítulo de resultados

\subsection{Análise microtomográfica}

\subsubsection{Análise quantitativa}

\subsubsection{Variável volume total $(\mathrm{VT})$}

Tabela 37 - Resultados da comparação entre grupos. Teste de Tukey para o VT

\begin{tabular}{|c|c|c|c|c|}
\hline & & Mean & a & b \\
\hline & $\ldots\{4\}$ & 95,04580688 & $\mathrm{xxxx}$ & \\
\hline & $\ldots \quad\{3\}$ & 102,7212982 & $\operatorname{xxxx}$ & \\
\hline & $\ldots \quad\{1\}$ & 107,2913818 & $\mathrm{xxxx}$ & \\
\hline & $\ldots \quad\{2\}$ & 126,3047409 & & $\mathrm{xxxx}$ \\
\hline
\end{tabular}

1.OS; 2.BI; 3.BO; 4.AU. Grupos com xxxx na mesma coluna não possuem diferença entre si

Tabela 38 - Resultados da comparação entre períodos. Teste de Tukey para o VT

\begin{tabular}{|c|c|c|c|}
\hline & Mean & 1 & 2 \\
\hline ... 8 weeks $\{1\}$ & 100,1115494 & $\mathrm{xxxx}$ & \\
\hline .... 4 weeks $\{2\}$ & 109,1588974 & $\operatorname{xxxx}$ & $\mathrm{xxxx}$ \\
\hline .... 2 weeks $\{3\}$ & 114,251976 & & $\operatorname{xxxx}$ \\
\hline
\end{tabular}

Grupos com xxxx na mesma coluna não possuem diferença entre si

\subsubsection{Variável volume ósseo neoformado (VO)}

Tabela 39 - Resultados da comparação entre grupos. Teste de Tukey para o VO

\begin{tabular}{|cccccc|}
\hline 3 & $\ldots$ & $\{3\}$ & Mean & 1 & 2 \\
\hline 2 & $\ldots$ & $\{2\}$ & 24,26815605 & $\mathrm{xxxx}$ \\
1 & $\ldots$ & $\{1\}$ & 34,34838867 & $\mathrm{xxxx}$ \\
\hline
\end{tabular}

1.OS; 2.BI; 3.BO. Grupos com xxxx na mesma coluna não possuem diferença entre si

\subsubsection{Variável relação volume ósseo neoformado/volume total (VO/VT)}

Tabela 40 - Resultados da interação. Teste de Tukey para a relação VO/VT

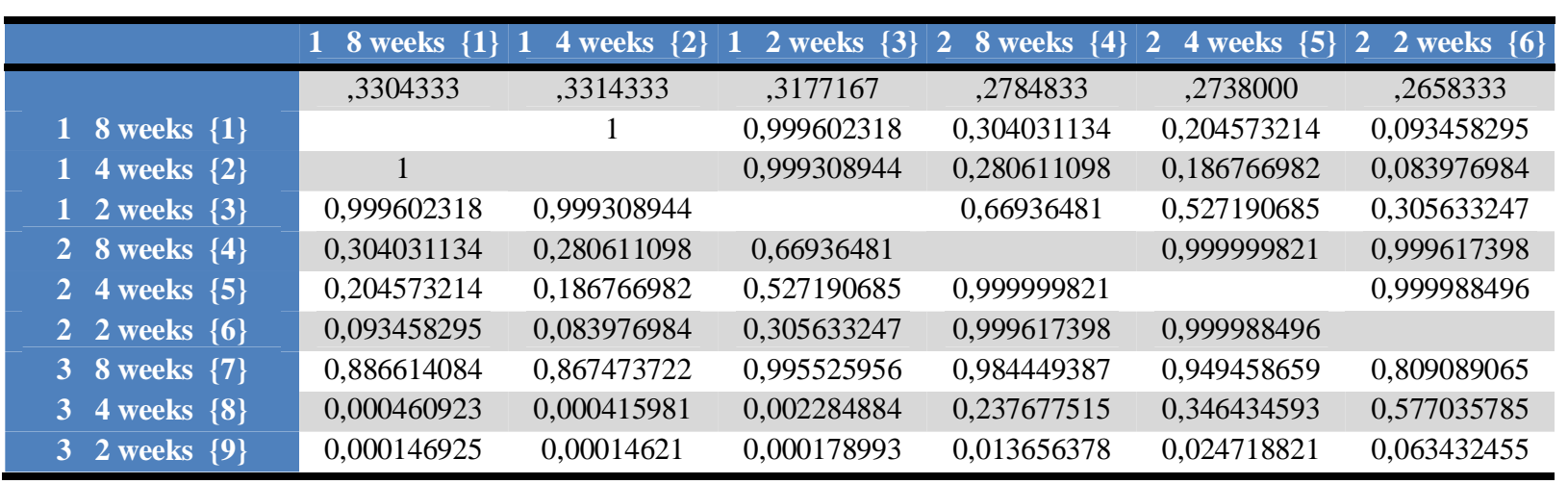




\begin{tabular}{|c|c|c|c|}
\hline & 38 weeks $\{7\}$ & 34 weeks $\{8\}$ & 32 weeks $\{9\}$ \\
\hline & ,2999500 & ,2235500 &, 1976833 \\
\hline 18 weeks $\{1\}$ & 0,886614084 & $0,000460923 *$ & $0,000146925^{*}$ \\
\hline 14 weeks $\{2\}$ & 0,867473722 & $0,000415981 *$ & $0,00014621 *$ \\
\hline 12 weeks $\{3\}$ & 0,995525956 & $0,002284884 *$ & $0,000178993 *$ \\
\hline 28 weeks $\{4\}$ & 0,984449387 & 0,237677515 & $0,013656378 *$ \\
\hline 24 weeks $\{5\}$ & 0,949458659 & 0,346434593 & $0,024718821 *$ \\
\hline 22 weeks $\{6\}$ & 0,809089065 & 0,577035785 & 0,063432455 \\
\hline 38 weeks $\{7\}$ & & 0,023866773 & 0,000784159* \\
\hline 34 weeks $\{8\}$ & 0,023866773 & & 0,952460647 \\
\hline 32 weeks $\{9\}$ & 0,000784159 & 0,952460647 & \\
\hline
\end{tabular}

1.OS; 2.BI; 3.BO. *significância para $\mathrm{p}<0,05$

\subsubsection{Variável número de trabéculas (NT)}

Tabela 41 - Resultados da comparação entre grupos. Teste de Tukey para o NT

\begin{tabular}{cccccc}
\hline 3 & $\ldots$ & $\{3\}$ & Mean & 1 & 2 \\
\hline 2 & $\ldots$ & $\{2\}$ & 4,988816738 & $\mathrm{xxxx}$ & $\mathrm{xxxx}$ \\
$\mathbf{1}$ & $\ldots$ & $\{1\}$ & 6,823316574 & $\mathrm{xxxx}$ \\
\hline
\end{tabular}

1.OS; 2.BI; 3.BO. Grupos com xxxx na mesma coluna não possuem diferença entre si

\subsubsection{Variável espessura das trabéculas (ET)}

Tabela 42 - Resultados da comparação entre grupos. Teste de Tukey para a ET

\begin{tabular}{cccccc}
\hline 3 & $\ldots$ & $\{3\}$ & 0,050577778 & 1 & 2 \\
\hline 2 & $\ldots$ & $\{2\}$ & 0,060566667 & $\mathrm{xxxx}$ & $\mathrm{xxxx}$ \\
1 & $\ldots$ & $\{1\}$ & 0,073700003 & $\mathrm{xxxx}$ & $\mathrm{xxxx}$ \\
\hline
\end{tabular}

1.OS; 2.BI; 3.BO. Grupos com xxxx na mesma coluna não possuem diferença entre si

\subsubsection{Variável separação entre as trabéculas (ST)}

Tabela 43 - Resultados da comparação entre grupos. Teste de Tukey para o ST

\begin{tabular}{cccccc}
\hline 3 & $\ldots$ & $\{3\}$ & 0,163877785 & 1 & 2 \\
\hline 2 & $\ldots$ & $\{2\}$ & 0,167300001 & $\mathrm{xxxx}$ & \\
1 & $\ldots$ & $\{1\}$ & 0,236944437 & & $\mathrm{xxxx}$ \\
\hline
\end{tabular}

1.OS; 2.BI; 3.BO. Grupos com xxxx na mesma coluna não possuem diferença entre si 